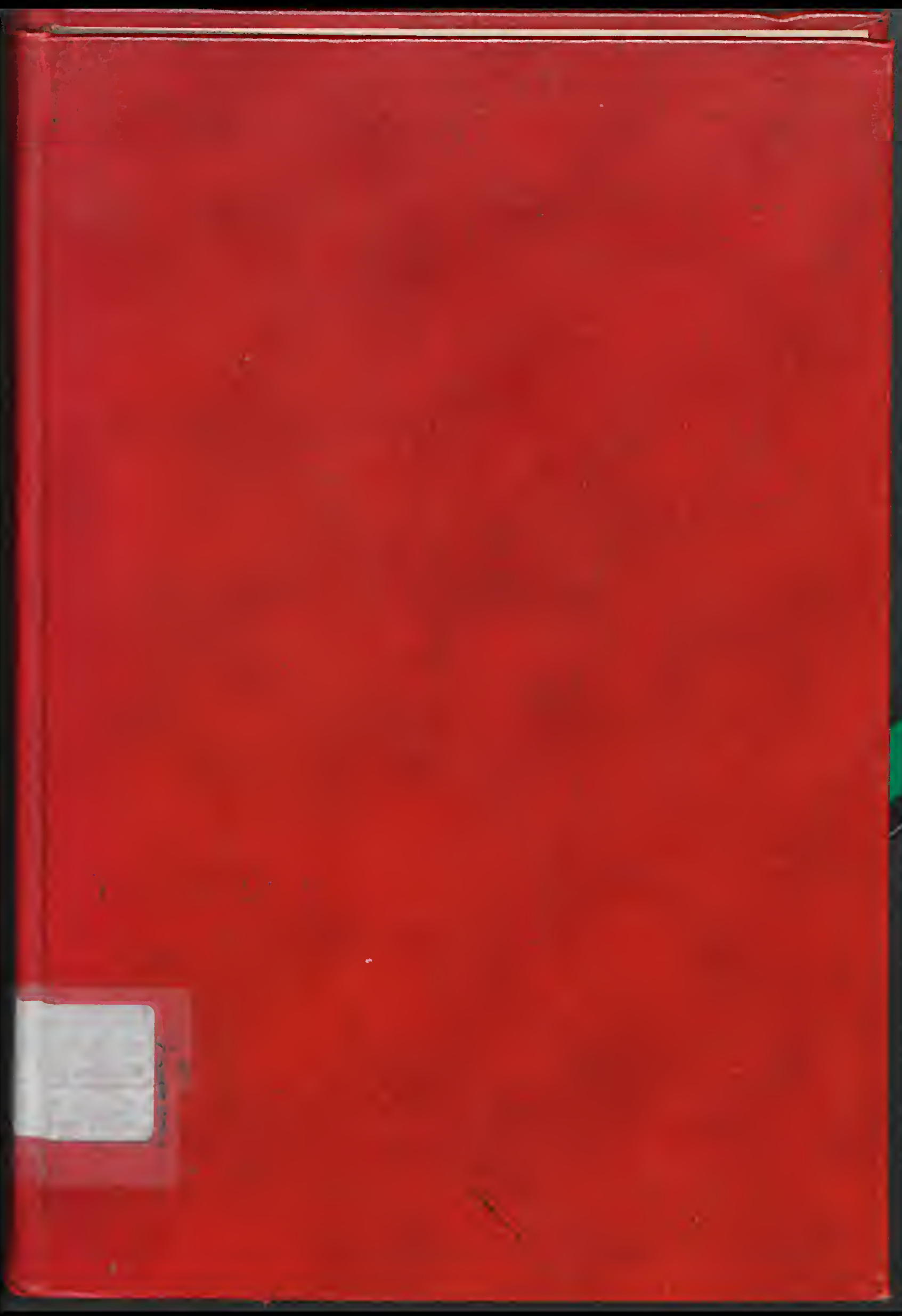

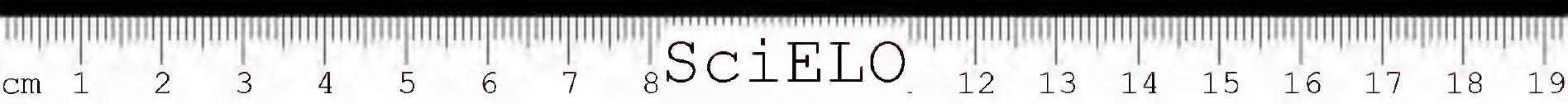




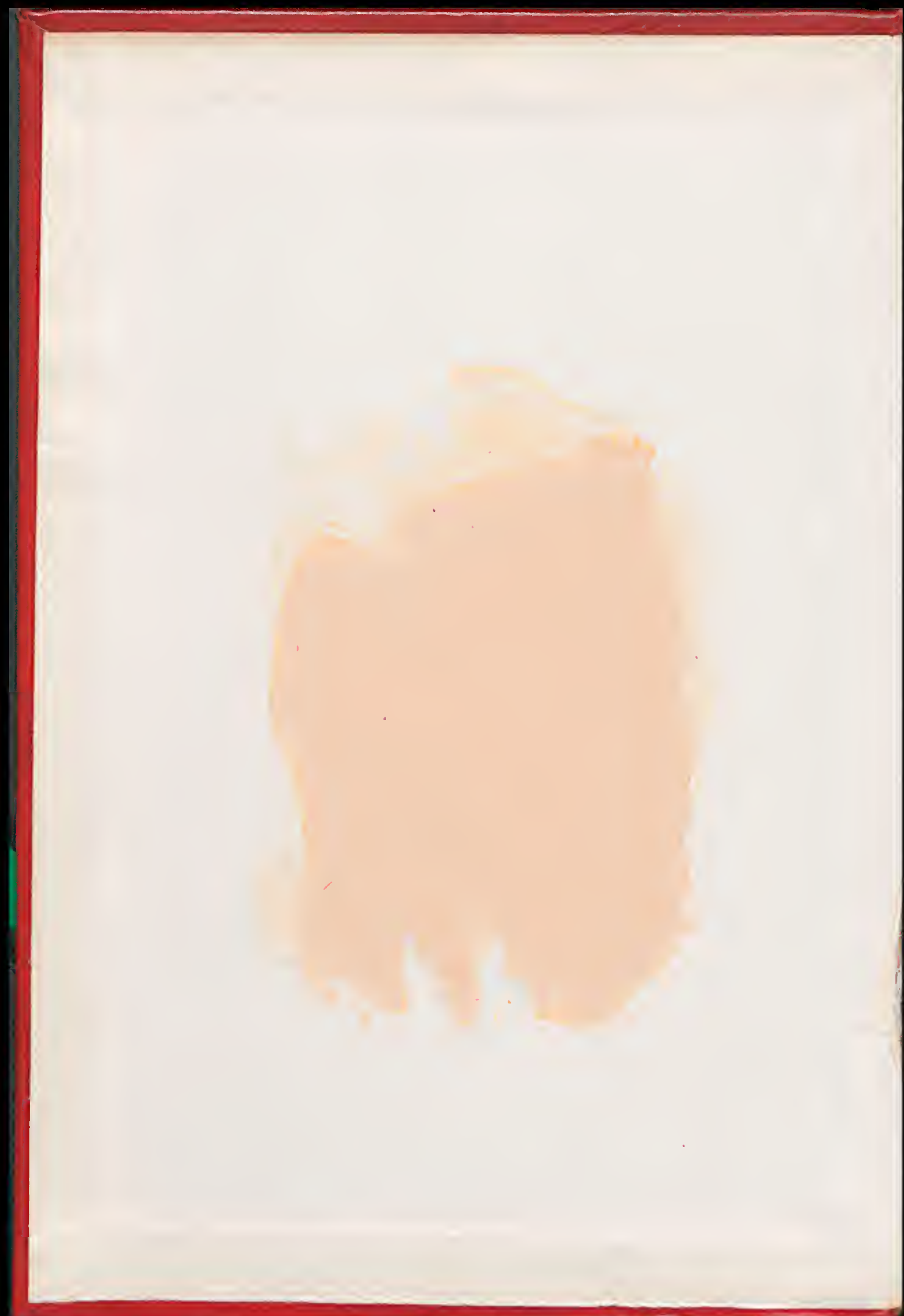

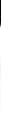




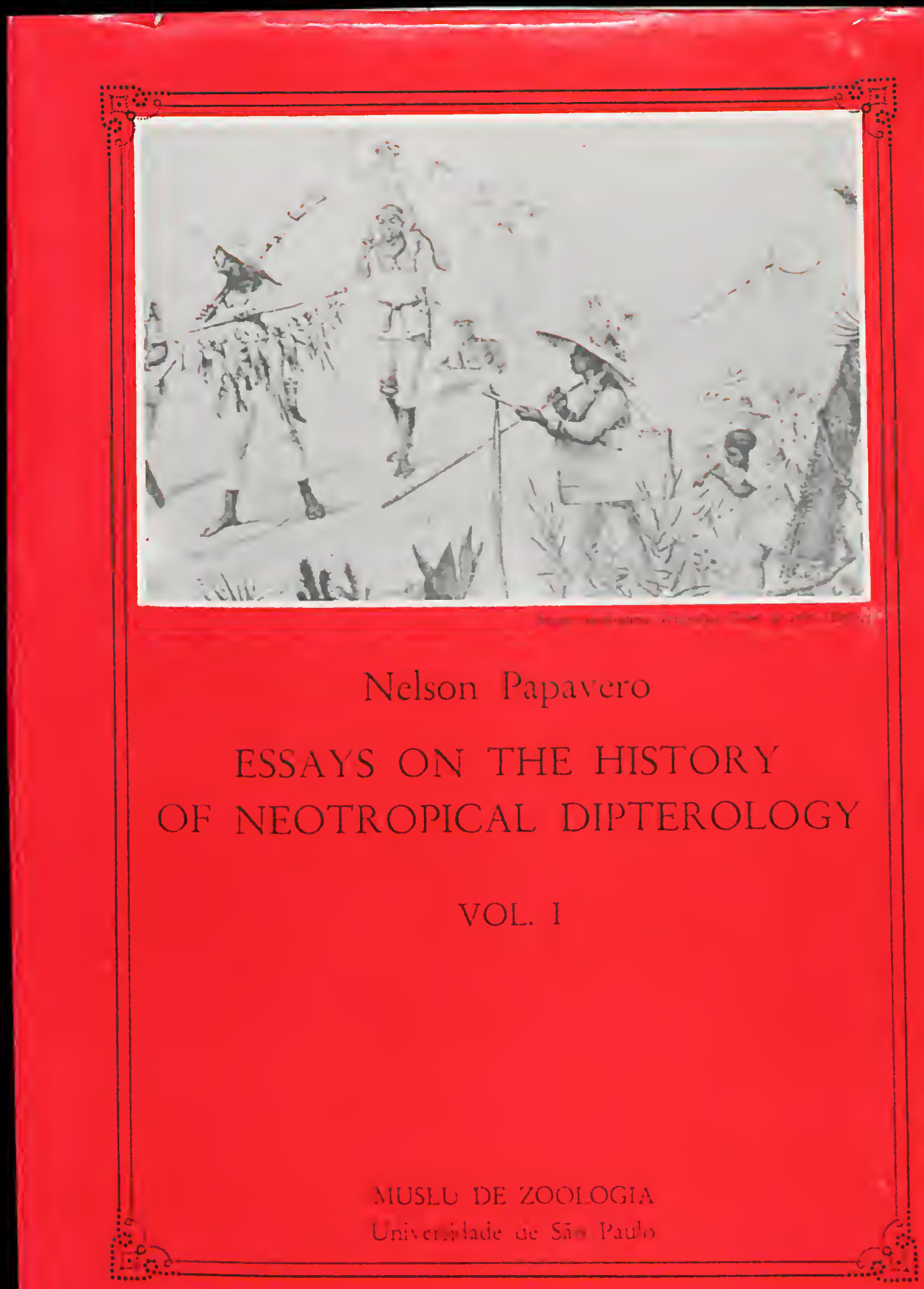

|

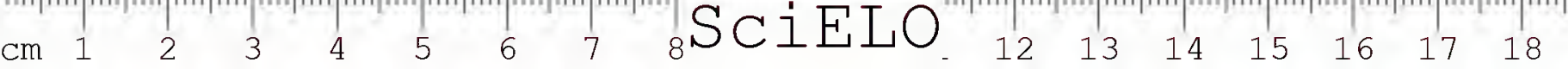




\section{ESSAYS ON THE HISTORY OF NEOTROPICAL DIPTEROLOGY}

This work, which will comprise three volumes, will complement the "Catalogue of the Diptera of the Americas South of the United States", edited by the Museum of Zoology, University of S. Paulo, since 1966, with the cooperation of 50 specialists from several countries. The main purpose of this book is to elucidate the problems related to. type-localities of the species described by the dipterists of the past two centuries.

The information is partly arranged according to the nationality of the collectors and authors. The first volume of this book will cover the periods of Linnaeus, Fabricius, Thunberg, Erichson, Perty, Wiedeman, and the French authors. In the second volume will be covered the periods of the British authors, the German and Austrian authors, of Wulp and Weyenbergh, the brothers Lynch Arribalzaga, the Italian dipterists, Fritz Müller and Emil Goeldi, Herbert Huntingdon Smith, the Scandinaviam collectors, E. E. Austen, the North American authors of the late 19th century, the "Biologia Centrall Americana", ending with the travels of Schunuse. The third volume will contain a gazetteer of the locality names em. ployed by the authors and their actual meaning.

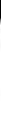




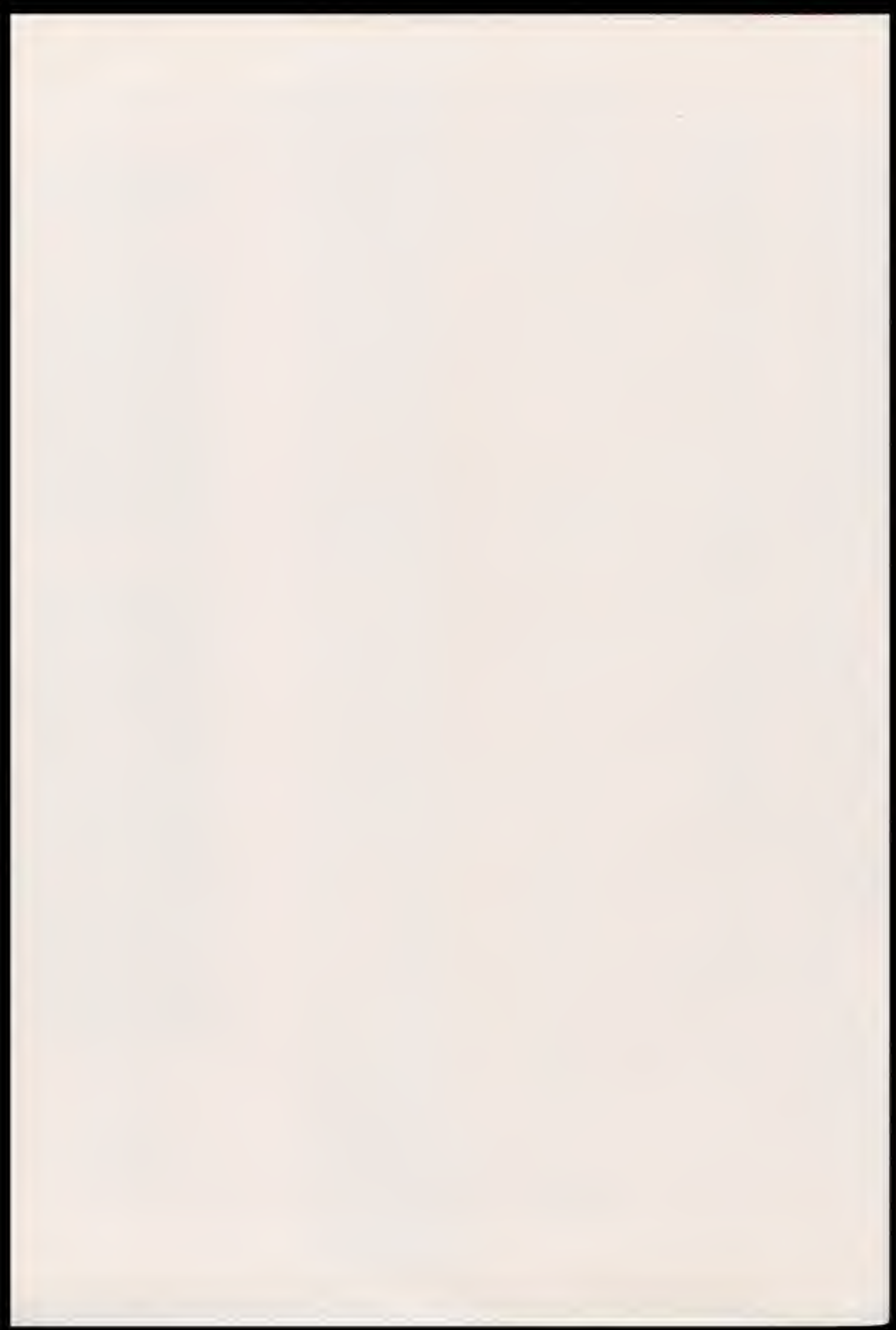

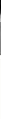


Essays on the history of Neotropical Dipterology 
Museu de Zoologia

Universidade de São Paulo

N. Papavero

\section{Essays on the history of Neotropical Dipterology,}

with special reference to collectors

(1750-1905)

Vol. I

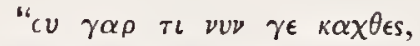

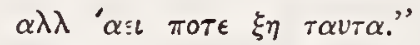
'For these things live not today or yesterday. but for all time.'

SOPHOCLES

São Paulo

1971

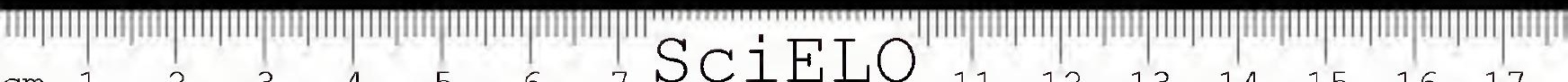


Cover design, Luis Díaz

EG Printed by Emprêsa Gráfica da Revista dos Tribunais S.A.

BT Rua Conde de Sarzedas, 38, São Paulo, Brasil, on 26.IV.1971. 
To

Lindolpho Rocha Guimatāes Messias Carrera

To all the dipterists who cooperated with the Catalogue of Neotropical Diptera

this book is dedicated 


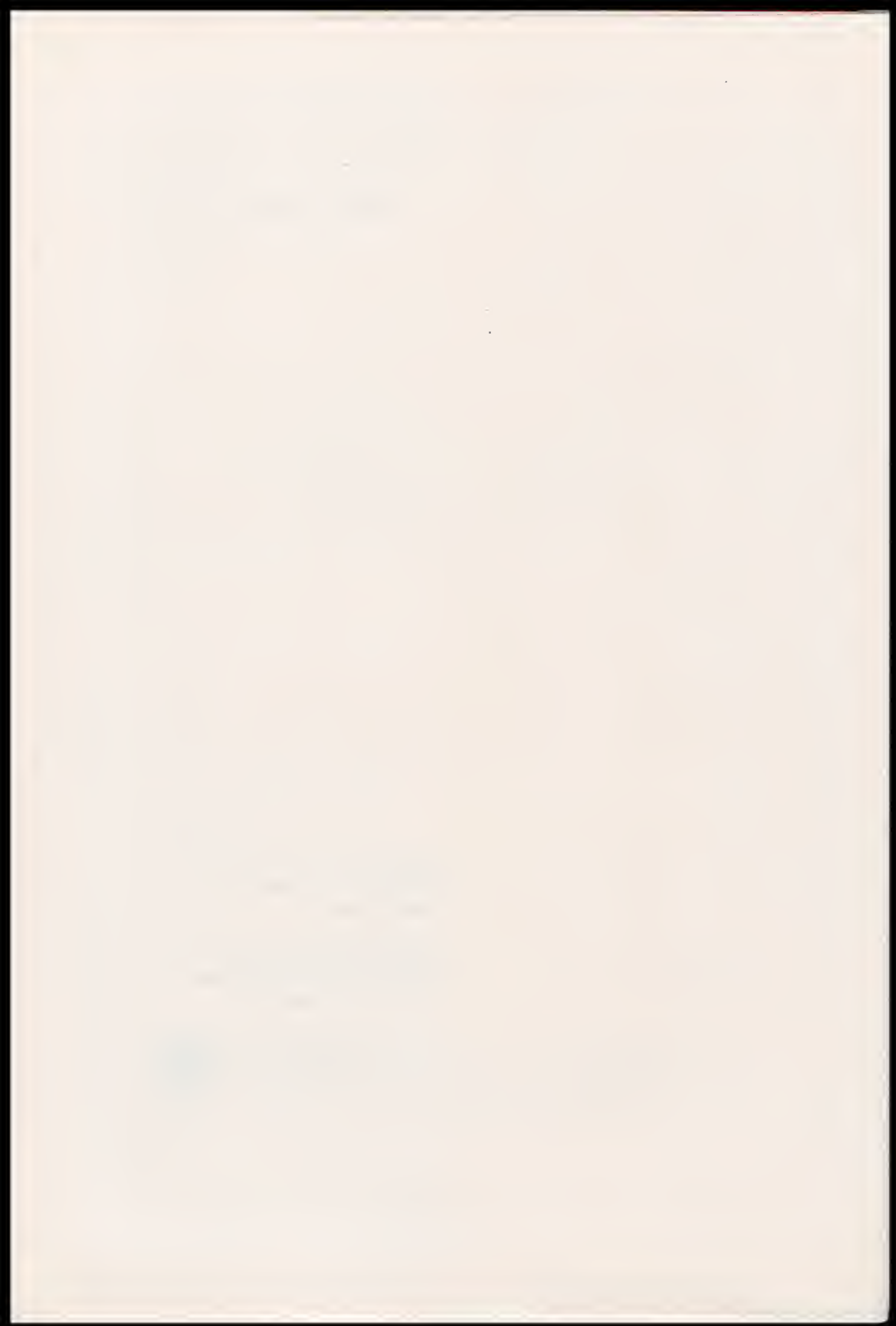

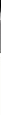




\section{List of Illustrations}

\section{Figures}

Title-page of Loefling's book of travels (pp. 6-7)

Party of naturalists collecting near Rio de Janeiro (Rugendas) (pp. 16-17) The city of Vila Boa (now Goiás) (Pohl) (pp. 28-29)

Baron von Langsderff's Farm Mandioca (Spix \& Martius) (pp. 50-51)

Neighborhood of Farm Mandioca, Serra dos Orgãos, Rio de Janeiro (Rugendas) ( $F p$. 90-91)

Lagoa das Aves, Minas Gerais (Spix E Martius) (pp. 104-105)

T'ijuca waterfall, near Rio de Janeiro (Rugendas) (pp. 124-125)

Negro naturalists returning from a trip (Debret) (pp. 134-135)

The city of Vila Rica (now Ouro Prêto), Minas Gerais (Pohl) (pp. 178. 179)

Mules being loaded for a zoological journey (Prince Wied-Neuwied) (pp. 190-191)

\section{Maps}

1. Humboldt's travels through Venezuela (pp. 36-37)

2. Humboldt's travels through Nueva Grenada (Colombia) (pp. 38-39)

3. Humboldt's travels through Ecuador and Peru (pp. 40-41)

4. Humboldt's travels through Mexico (pp. 42-43)

5. Travels of Langsdorff through Brazil (pp. 54-55) 
6. Travels of Pohl through Minas Gerais and Goiás (pp. 62-63)

7. Travels of Spix and Martius through Brazil (pp. 66-67)

8. Travels of Sellow through Brazil and Uruguay ( $p p, 74-75$ )

9. Travels of Natterer through Brazil ( $p$. 82-83)

10. Travels of Saint-Hilaire through Brazil and Uruguay (pp. 118-119)

11. Travels of d'Orbigny through Bolivia (pp. 140-141)

12. Travels of Castelnau through South America (pp. 154-155)

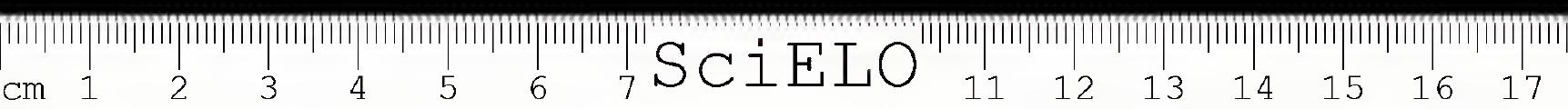




\section{Contents}

PAGE

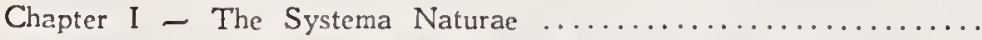

Carolus Linnaeus - The Treaty of Madrid and P. Loefling Dahlberg and Rolander - Carolus Linnaeus Jr.

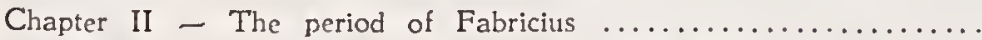

The Cruise of the "Endeavour" - L. C. M. Richard - Palisot de Beauvois - L. A. G. Bosc - J. P. B. von Rohr - "Smidt" Pflug and Yeats

Chapter III - The life and works of J. C. Fabricius ...........

Chapter IV - Travels of Humboldt and Bonpland .............

Humboldt and Bonpland - The travel through Venezuela - The trips to Cuba, Nueva Granada, and Ecuador - The trip through Mexico - Humboldt and Bonpland after the travels - Pierre André Latreille

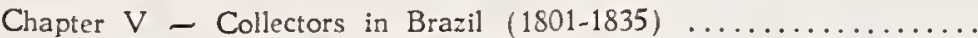

Hoffmarsegg's collectors: Sieber, Gomes, Feijo - The Russian expeditions - Sellow and Freyreiss - The Austrian expeditions Sellow's journeys in the interior of Brazil - J. Natterer - Kamerlacher - Bescke - Lund and Claussen

Chapter VI - Collectors in Mexico and the West Indies ..........

Forsström - Ferdinand Deppe's travels in Mexico - Hornbeck

Chapter VII - Thunberg, Erichson, Perty and Wiedemann .......

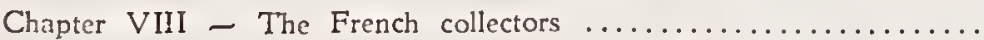

Saint Hilaire - Gaudichaud-Beaupré - A. Plèe — The voyage of 'La Coquille' - Leschenault and Doumerc - The voyage of 'La Thétis' and 'L'Espérance' - Lacordaire and Banon - A. D. d'Orbigny - Vauthier - Sylveira - The voyage of 'La Favorite' - F. R. M. Leprieur - Claude Gay - Francis de Castelnau - A. Pissis - P. Germain - M. de Mathan - P. E. Gounelle - M. A. Rojas Other collectors

Chapter IX - Entomological collectors in Mexico and Cuba ........

The exploration of Mexico - The exploration of Cuba: Sagra and Poey, Gundlach

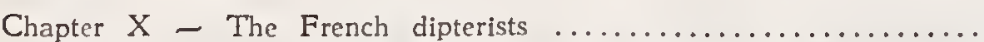

Guérin-Méneville — Olivier — Robineau-Desvoidy — Macquart

- Blanchard - Coquerel - Laboulbène - Bigot 


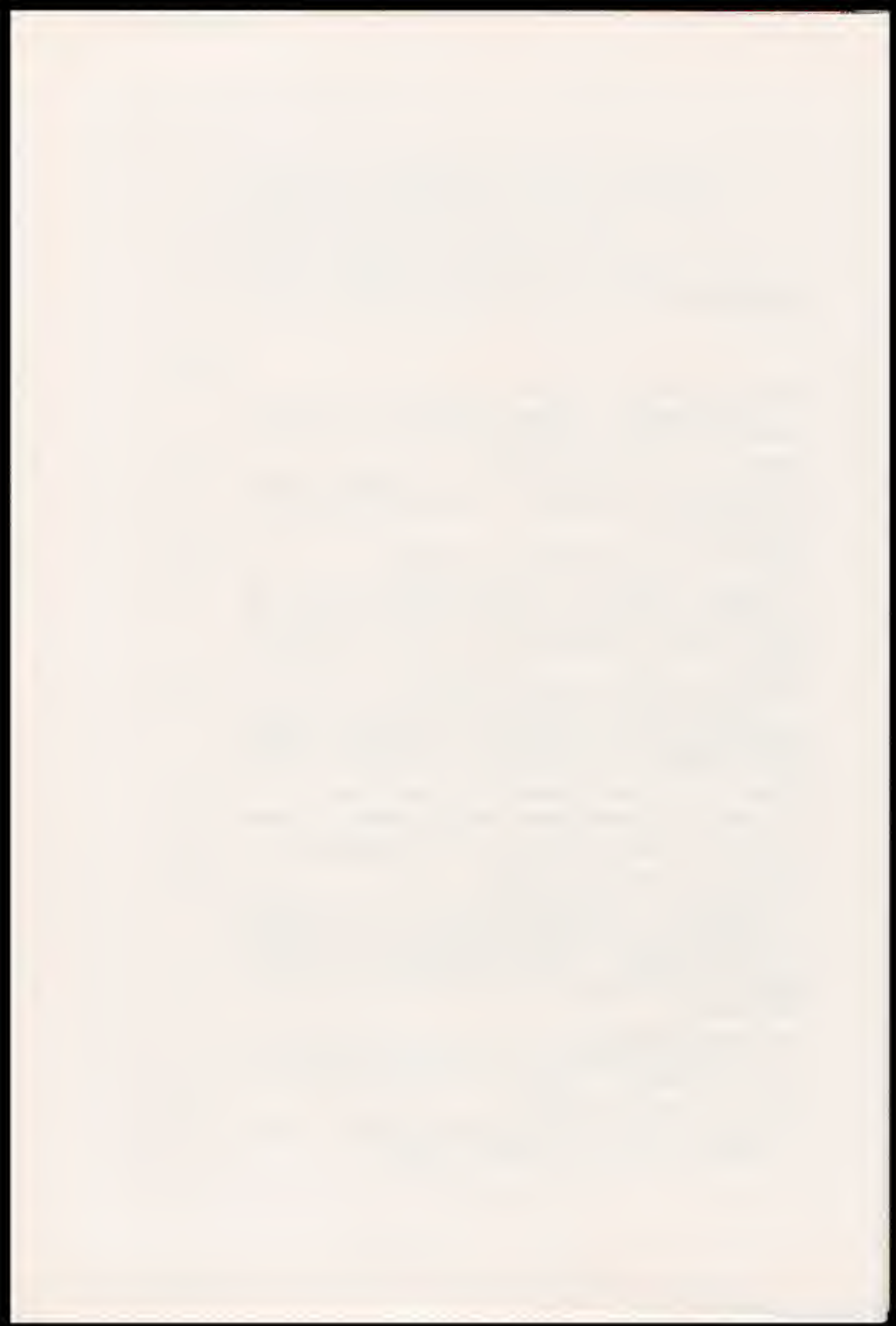

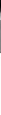




\section{Introduction}

One of the problems in the taxonomy of Neotropical Diptera is the identification of species described by earlier authors; the task is still complicated by the fact that most descriptions are unacompanied by the citation of a definite type-locality. Every worker in the field is familiar with vague citations such as "South America", "Brazil", or "New Grenada". The problem becomes acute because of the existence of closely related species occupying different areas, subspecies, ecotypes, vicariant forms, etc. A more precise and restricted type-locality can be an important clue to identification, at the same time permitting a correlation of the taxon involved with the morphoclimatic aspects of the area it occupies. The lack of information on the sources of material available to the earlier dipterists caused many authors to misidentify the ancient species. Macquart's "Rio Negro, M. d'Orbigny" has been interpreted as being the river of the same name in northern Brazil, whereas it means exactly (as will be seen in one of the chapters of this book) the city of Carmen de Patagones, Province of Buenos Aires, in Argentina. A similar error can cause serious problems not only in systematics, but more esfecially when one is working with the geographical distribution of a group. Instances like this could be cited for every author who dealt with Neotropical Diptera.

With this in mind I have attempted to investigate the sources of materials available to the earlier authors, reconstructing the itineraries of the collectors who provided the specimens.

The following general bibliographic sources were consulted for this compilation:

(i) For bicgraphies of collectors and authors - Berger, 1964 (an excellent bibliography, containing all great voyages): Carpenter, 1945, 1953 (a basic bibliography of bioghaphies); Chardon, 1949 (for naturalists travelling in Central America and the West Indies); Garcia, 1922, and Hoehne, 1942 (itineraries of most collectors in Brazil): Horn \& Schenkling, 1928-1929. and Mello-Leitão, $19 \frac{1}{1}$ (general information on collectors and collections, and expeditions); Montemont, 1834-1835 (an amazing compilation of early voyages): Pennel, 1945 (good information on "difficult" collectors); Urban, 1903. 1908 (one of the best sources on collectors; some of his are the only available data in the all literature).

(ii) For the fate of individual collections of entomology in the world Hiorn, 1929, and Horn \& Schenkling, 1935-1937.

(iii) For information on the development of biological sciences - MelloLeitão, 1937, and Nordenskiöld, 1936.

More specific references are added at the end of each chapter. In the case when all sources failed to give the required information, encyclopedias, more especially the "Grand Larousse du XIXe. Siècle", which contains many 
data not found elsewhere, have been used. Data obtained from encyclopedias are indicated in the text by "(Enc.)".

Geographical names are first cited in the original form used by the travelling naturalist in his writings, followed by the present used name and the coordinates necessary for its location on a map. Geographical names and coordinates are cited according to Hanson (1945) for names of countries outside Brazil, and to Vanzolini \& Papavero (1968) for Brazilian names. To avoid confusions, since cities have names of rivers, and vice-versa, all the rames of rivers, lakes, and other bodies of water are in italics in the text.

The information herein compiled is arranged partially chronologically, and partially according to the nationality of the collectors and authors. The first volume of this book will cover the periods of Linnaeus, Fabricius, Thunberg. Erichson, Perty. Wiedemann, and the French authors. In the second volume will be covered the periods of the British authors, the German and Austrian authors, of Wulp and Weyenbergh, the brothers Lynch Arriballzaga. the Italian dipterists, Fritz Müller and Emil Goeldi, Herbert Huntingdon Smith, the Scandinavian collectors, E. E. Austen, the North American authors of the late 19th century, the "Biologia Centrali Americana", ending with the travels of Schnuse. The third volume will contain a gazetteer of the locality names employed by century authors and their actual meaning.

Of some collectors we have very detailed itineraries; of others, meager information or no data at all. Whenever possible, I have included the complete itinerary of each collector, even if it is known that in some parts of the trip he did not collect Diptera, thus rendering this work useful to other branches of Zoology as well. Included also are some biographical notes on the authors who dealt with Neotropical Diptera in the $18 \mathrm{th}$ and 19 th centuries.

The year 1905 was established as the deadline for this book - first, because many of the 19th century authors died around that epoch, and second, because the two last great works of that century were published around that year - the Diptera volumes of the Biologia Centrali-Americana, and especially Aldrich's Catalogue of North American Diptera, which inaugurates a new era in the study of this branch of Entomology.

In the preparation of this work I have been helped by many people, who generously gave of their time and knowledge. I am very especially indebted to George C. Steyskal. U. S. Department of Agriculture, Agric. Res. Serv., Washington, D. C., for his kindness in revising the manuscripts, translating several papers, and for many suggestions and ideas. Drs. S. L. Tuxen, Universitetets Zoologiske Museum, Copenhagen; Mário Neme, Museu Paulista, Universidade de São Paulo; Gertrud Rita Kloss, Oliverio M. de Oliveira Pinto, and especially Paulo E. Vanzolini, Museu de Zoologia, Universidade de Säo Paulo, also contributed several useful references and criticisms, and revised the various parts of the manuscript. Dr. Mathilde Goulard de Westberg, Director of the Instituto Ibero-Americano, Göteborg. Sweden, has kindly permitted quotations from the books referring to Loefling, published by that Institution. Prof. Ernest E. Williams, Museum of Comparative Zoclogy, Harvard University, Cambridge, Mass., was also very helpful in the correction of the originals, and in offering many suggestions.

Drs. Harold Oldrcyd, British Museum (Natural History), London; D. M. Ackland and E. Taylor, Hope Department of Entomology, Oxford University, Oxford; and especially L. Matile, Muséum National d'Histoire Naturelle, Paris, were extremely kind in facilitating the consult of several manus-- 
cripts, references and accession books. Consultation of historical manuscripts deposited in the archives of the Museu Nacional, Rio de Janeiro, was made possible through the cooperation of Dr. José Cândido M. de Carvalho.

To the Fundação de Amparo à Pesquisa do Estado de Săo Paulo, in the person of its ex-scientific director, Prof. Alberto Carvalho da Silva, I am especially indebted for the Grant "Biolćgicas 68/604", which rendered possible the consultation of several references in the libraries of the United States. Grant 3289/69 of the Conselho Nacional de Pesquisas made possible the examination of several unpublished sources in England and France.

The maps of this volume were partially prepared by Francisca Carolina do Val; the photographs were taken by Giro Pastore, and the manuscript has been typed my Mrs. Odete Colombini Silva. To them my best thanks.

This book is necessarily incomplete, due to the scarcity of published references to collectors. Anyway, I hope that the data herein assembled may prove of some value to taxonomists especializing in Neotropical Diptera, and that they will encourage further publication of new data gained through the study of type materials, manuscripts, diaries, accession books and other sources.

N. Papavero

\section{References}

Berger, $P$.

1964. Bibliografia do Rio de Janeiro de viajantes e autores estrangciros (1531-1900), 322 pp. Livraria São Josè, Rio de Janeiro, GB.

Boinet, A.

1914. Cataloguc génèral des manuscrits des bibliothèques publiques de France. 2 (Muséum d'Histoire naturclle, École des Mines, Écoles des Ponts-et-chausèes. Ecole Polytechnique), vii + 564 pp. Ministére de l'Instruction Publique et des Beaux-Arts. Plon-Nourrit et Cie., Imprimeur - Editeurs, Paris.

Carpenter, M. M.

1945. Bibliography of biographies of entomologists. Amer. Midland Nat. 33 (1) : 1-116.

1953. Bibliography of biographies of entomologists. Supplement. Amer. Midland Nat. 50 : 257-348.

Chardon, C. E.

1949. Los naturalistas en la America Latina. Tomo I. Los siglos XVI, XVII y XVIII, Alejandro Humboldt, Carlos Darwin, La Española. Cuba y Puerto Rico, vii + 386 pp., 27 pls. Secretaria de Estado de Agricultura Pecuaria y Colonización. Editora del Caribe, c. por A. Ciudad Trujillo, R. Dominicana. 
Garcia, R.

1922. Historia das exploraçōes scientificas, pp. 856-910, in Instituto Historico, Geographico e Ethnographico Brasileiro, Diccionario Historico, Geographico c Ethnographico do Brasil 1 : 1688 pp., illus. Rio de Janeiro.

Hanson, E. P., ed.

1945. Index to map of Hispanic America 1:1.000.000. 923 pp. American Geographical Sosiety Publ. n 5. U. S. Govrnment Printing Office, Washington, D.C.

Hoehne, F. C.

1942. Notas bio-bibliográficas de naturalistas botânicos, in F. C. Hoehne, M. Kuhlmann E O. Handro, O Jardim Botánico de São Paulo, 656 pp., illus. São Paulo.

Horn, W.

1926. Über den Verbleib der entomologischen Sammlungen der Welt. Supplem. Ent. 12 : 1-133.

1929. Über den Verbleib der entomologischen Sammlungen der Welt (supplement with corrections). Supplem. Ent. $17: 72-120$.

Horn, W. E I. Kahle

1935-1937. Über entomologischen Sammlungen, Entomologen und Entomo-Museologie (3 parts). Beitr. z. Ent. 1 : $1-536$.

Horn, W. E S. Schenkling

1928-1929. Index litteraturae entomologicae. Serie I : Die Welt-Literatur über die gesamte Entomologie bis inklusive 1863, 1 (1928) : 1-532, 1 pl.; 2 (1928) : 353-704, 1 pl.: 3 (1928) : XxI + pp. 705-1056, 1 pl.; 4 (1929) : 1067-1426, 1 pl. W. Horn, Berlin-Dahlem.

Mello-Leitão, C. de

1937. A biologia no Brasil, 331 pp., Biblioteca Pedagógica Brasileira, Série 5", Brasiliana, Vol. 99. Companbia Editôra Nacional, São Paulo.

1941. História das expediçōes cientificas no Brasil, 360 pp. Biblioteca Pedagógica Brasileira, Série 5", Brasiliana, Vol. 209. Companhia Editôra Nacional, São Paulo.

Montemont, M. A.

1834-1835. Histoire naturelle dcs voyages, effectués par mer et par terre dans les cinq parties du monde, sur les divers points du 
globe, contenant la description des moeurs, costumes, gouvernements, cultes, sciences et arts, industrie et commerce, productions naturelles et autres, 46 vols. Armand-Aubrée Libraire-Éditeur, Paris.

Nordenskiöld, E.

1936. The history of biology, a survey, $\mathrm{x}+629+\mathrm{xv}$ pp. illus. Tuder Publ. Co., New York.

Pennell, F. W.

1945. Historical sketch, pp. 35-48, in F. Verdoorn, ed., Plants and plant sciences in Latin America, 381 pp. illus. Chronica Botanica Co., Waltham, Mass.

Urban, I.

1903. Notae biographicae peregrinatorum Indiae Occidentalis botanicorum, in his Symbolac Antillanae 3 (1) : 14-158. Lipsiae (= Leipzig)

1908. Vitae itineraque collectorum botanicorum, notae collaboratorum biographicae, Florae Brasiliae ratio edendi chronologica, systema, index familiarum, in C. F. F. von Martius et al., Flora Brasiliensis, enumeratio plantarum hactenus detectarum quas suis aliorumque botanicorum studiis descriptas et methodo naturali digestas partion icones illustratas 1 (1) : cX + $266+31$ pp., 59 pls.

Vanzolini, P. E. E N. Papavero

1968. Indice dos topónimos contidos na Carta do Brasil 1:1.000.000 do I.B.G.E., (v1) + 292 pp. Fundação de Amparo à Pesquisa do Estado de São Paulo. 


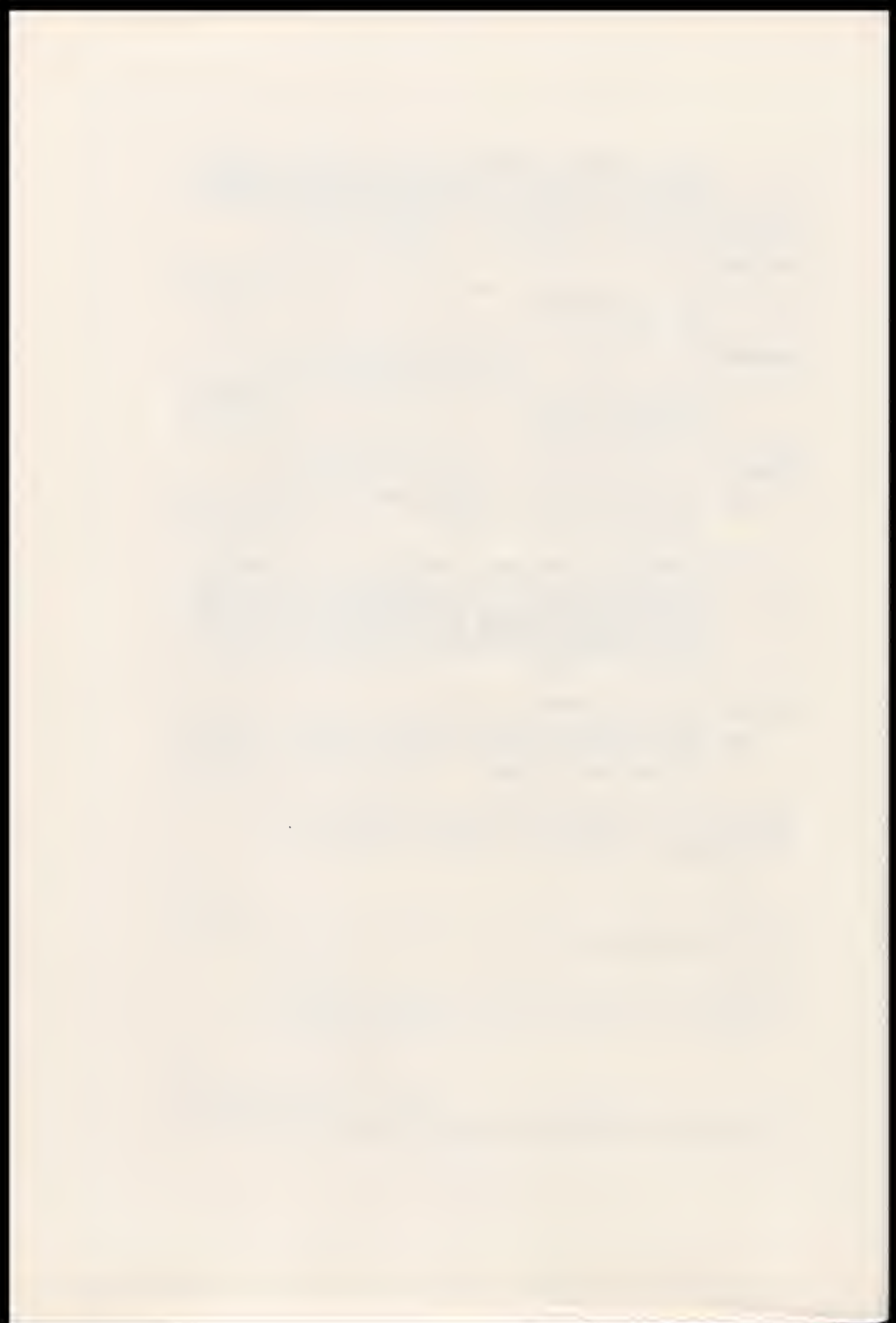

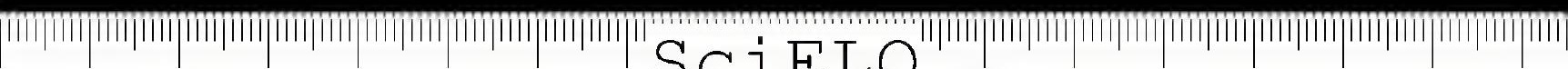

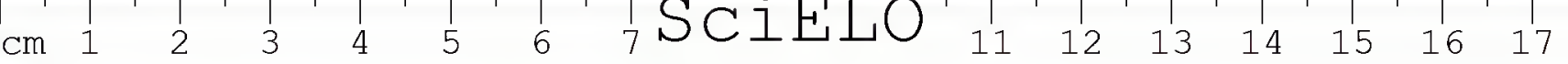




\section{Chapter I}

\section{The Systema Naturae}

\section{Carolus Linnaeus}

Carl Linné, or in Latinized form, Carolus Linnaeus, was born on 23 May 1707, in the small city of Raashult, in the province of Smaaland, Sweden. After primary studies in Växiö, Linnaeus went to the University of Lund (1727). The Swedish universities at that time were passing through a severe financial crisis; the poor pay of the teachers was reflected in the quality of the lectures, and the students greatly suffered with the system. In Lund, the only place where Linnaeus could learn something was the library of Professor Kilian Stobaeus. During the night, with the help of a servant of Stobaeus, Linneaeus entered the library, and took books to study, promising they would be returned next morning. When Stobaeus discovered the fact, he not only opened the library to the young student, but gave him also full support.

Soon afterwards Linnaeus moved to Uppsala, where he found the protection of two leading scientists, Olof Rudbeck and Olof Celsius. Here Linnaeus' fame began to grow with his first revolutionary botanical publications. During that time he lived in Rudbeck's house, as preceptor of his sons.

After his first successes in Uppsala, Linnaeus was commissioned by the University to undertake an excursion to Lapland, whence he returned several months later, with large collections. 
In 1734 he made another trip, this time invited and financed by Nils Reuterholm, mayor of Dalarna, to explore other regions of Scandinavia.

In the meantime, Linnaeus' situation was indefinite - half-student, half-teacher, and simultaneously a travelling naturalist, the years were passing rapidly, and he neither obtained his grade nor abandoned the University to start on a career. As it was not obligatory to obtain a degree in the same university where one had studied, Linnaeus decided to go to a foreign university, having at the same time the chance to travel abroad. Before leaving Sweden, he went to Dalarna, where at the house of Johan Moraeus he had previously met the girl whom he would eventually marry - Sarah Elisabeth Moraeus. Her father financed Linnaeus' studies in Holland.

In 1735, Linnaeus sailed from Helsingborg, in the south of Sweden, for Lübeck, proceeding overland to Hamburg, where he remained for some time. Aboard a sailing ship he went to Amsterdam, but the cruise took 16 days due to contrary winds. Upon arriving in Holland he immediately headed for the small town of Hardewijk, in Gelderland, where there was a university much favoured by medical students. In the same day of his arrival Linnaeus passed the examinations for the medical course. On 24 June of the same year he received the title of "Doctor Medicinae", having defended the thesis De Hypothesis nova de febrium intermitentium causa.

After that he decided to remain in the Netherlands for a while, and entered the University of Leyden. Here again he found the protection of influential scientists, J. F. Gronovius and Isaac Lowson. Through the intercession of Hermann Boerhaave, Linnaeus obtained the post of private doctor to George Clifford, the owner of a rich botanical and zoological garden at Hartecamp, between Leyden and Haarlem. There Linnaeus remained studying the natural productions. In the "Hortus Cliffortianus" he completed a manuscript which was printed in 1735 with the help of Gronovius and Lowson. The resulting booklet, with only 13 pages, devised a new system of classification and was destined to cause a revolution in the biological sciences - it was the Systema Naturae.

By the end of 1737 Linnaeus decided to return to Sweden, and left the gardens of Clifford. On his arrival to Leyden, however, he was persuaded by Boerhaave and Gronovius to remain a little longer in the Netherlands, so that he left the country only in May 1738. But instead of going directly home, he first went 
to Paris, where he met the brothers Jussieu, the famous entomologist René Antoine Ferchauld de Réaumur, and other naturalists. whose acquaintance would be valuable to his future studies.

In the middle of the summer of 1738 he arrived in Sweden. The situation of the universities had not changed, and he could not get a position as a teacher. Hence he decided to live as a practicing doctor in Stockholm. Soon he became widely known as an excellent professional, and started making money. Now he was able to marry Sarah Elisabeth Moraeus, who had patiently waited for his return; the marriage was performed in June 1839. In that same year he founded the "Svenska Vetenskaps Akademien", and was its first president.

In 1740 Olof Rudbeck died, aged 80, and Linnaeus applied for the chair of botany and anatomy, left vacant. However, his rival, Nils Rosen, was the winner. At the same time the chair of practical medicine was also-left vacant on account of the retirement of Roberg, and Linnaeus occupied the post. As he preferred the chair of botany to that of medicine, he proposed to exchange chairs with Rosen, and as the authorities of the University of Uppsala had nothing against this, the exchange was made.

Linnaeus could finally develop all his capacities as a researcher and a teacher. Due to his fame and influence, he was able to assemble a number of bright students who travelled to the most distant regions of the Earth, collecting plants and animals, which went to enrich the subsequent editions of the Systema Naturae, and the recently founded Museum of Natural History of the University of Uppsala.

Of the South American fauna and flora, however, very little was known. During the Dutch invasion of Brazil in the 17th century, Georg Marcgrave had studied the peculiar fauna of that colony, publishing in 1648 his Historiae rerum naturalium Brasiliae; his companion Wilhelm Piso had also discovered several secrets of the nature of that region, explained in his De Indiae utriusque re naturali et medica (1658). From the distant colony of Surinam, Madame Maria Sybilla Merian had brought to Holland magnificent insects, reproduced in superb coloured plates in her Metamorphoses insectorum Surinamensium (1705).

These and other books, which excited the imagination of learned Europe, have certainly influenced Linnaeus, who eagerly wanted to send some of his disciples to those mysterious regions.

Linnaeus' wish would be satisfied in consequence of a treaty between the Kingdoms of Spain and Portugal, which shared, and zealously guarded, the South American continent. 


\section{The Treaty of Madrid and P. Loefling}

By the Treaty of Madrid, entered into by Ferdinand VI of Spain and Doın João $V$ of Portugal, in 13 January 1750, it was agreed that new frontiers should be established between their respective colonies in South America. Portugal ceded to Spain the Colony of Sacramento (now Colonia, in Uruguay), in exchange for the Spanish "Siete Pueblos de Misiones", the Jesuitic settlements situated in what is now the western part of the State of Rio Grande do Sul, in Brazil. To the north, in the Amazonian region, the frontiers were demarcated between several regions, one of the difficult points being the dividing line between the rivers Negro and Orinoco.

The same Treaty also established two commissions, responsible for a thorough study of the regions involved and for the demarcation of the northern frontiers, as both Kingdoms were very much concerned with the expansion of the French, English, and especially the Dutch, in the Guianas.

The Portuguese commission was headed by Captain General Francisco Xavier de Mendonça Furtado. In October 1754, he headed for the Rio Negro to wait there for his Spanish counterpart. Mendonça Furtado was accompanied by no less than 769 persons, among them physicians, astronomers, geographers, 205 soldiers, 24 river pilots, 411 canoemen (almost all Indian), 62 servants and slaves. Established in Mariuá (presently Barcelos, State of Amazonas, Brazil), he waited in vain for the arrival of the Spanish commission and returned to Belém in 1755 (Serrano, 1922).

The Spanish Commission was commanded by Don Joseph de Iturriaga and was composed of 800 members. Among them was one of Linnaeus' disciples, P. Loefling.

PEHR LOEFLing was born on 31 January 1729, at Tollfors, Valbo, in the Province of Gästrikland, Sweden, the son of Erik Loefling and Barbara Strandman. He went to the University of Uppsala in 1743 to study natural history under Linnaeus, being one of his favorite disciples. As in 1751 the King of Spain had requested the presence of one of Linnaeus' students to investigate the flora of his Kingdom, Loefling - who had already finished his courses and received his doctor's degree - was invited and gladly accepted.

Armed with a passport granted by King Adolf Frederick of Sweden, a letter of recommendation from the Dean of the University of Uppsala, and Linnaeus' instructions for the researches 
he should undertake in Spain ("Instruction för Hr. P. Loefling at observera uti Spanskariket"; see Anon., 1907). Loefling departed from Uppsala for Stockholm, where the Royal Academy of Sciences presented him with several instruments to be used in his investigations; the Direstor of the Company of the East Indies. Clas Grill, granted him a free voyage to Spain in one of the Company's ships, and finally the Ambassador of Spain, Marquis of Grimaldi, gave him the money necessary for the enterprise.

Loefling left Stockholm on 16 May 1751. Two months later he landed in Oporto, Portugal, and proceeded to Lisbon, where he met Louis Goudin. one of the members of La Condamine's expedition to South America, back in Europe after 16 years of absence. Loefling and Goudin travelled to Madrid, arriving on 20 October 1751. Goudin introduced Loefling to the Prime Minister, Don José de Carvajal y Lencastre, as well as to other influential people in the Court.

Loefling started collecting plants in Madrid and its neighborhood, assembling more than 1,400 specimens. He was planning to follow on a botanical trip to the Pyrenees, but was officialy invited to join the scientific staff of Don Joseph de Iturriaga's expedition. This was a most rare and welcome opportunity to study the natural productions of the Spanish possessions in South America, and Loefling promptly accepted. Two young medical doctors interested in natural sciences, Benito Pastor and Antonio Condal, and two artists, Juan de Dios Castel and Bruno de Salvador y Carmona, would assist him in his scientific works.

The members of the expedition sailed from Cádiz aboard the frigate "Santa Ana", on 15 February 1754 . On the 24 th passed the Canary Islands, on 3 April Tobago, and on the 4 th Grenada and Margarita, arriving at Cumaná, then the capital of the $\mathrm{Vi}$ cekingdom of Nueva Andalucia and presently the capital of the State of Sucre, Venezuela, on 11 April 1754. However, the refusal of the local missionaries to furnish transportation up the Orinoco resulted in the failure of the expedition, and Iturriaga and Mendonça Furtado never made contact to establish the frontiers.

Meanwhile, having for headquarters the city of Cumaná (NC-20, 10-64a), where he stayed for almost 6 months, Loefling went to Barcelona (NC-20, 10-65b; now in the State of Anzoátegui), arriving on 25 July. From Barcelona he went to collect in the Misiones de Piritu (NC-20, 10-65a), then proceeding to the "Quebrada de Chipicuapa" (locality unknown to me), the 
"población" of Clarines (NC-20, 10-65c), passing through Caracas (D.F., NC-19, 11-67d) and Puerto Cabello (NC-19, 10 $-68 \mathrm{a})$, and finally arrived at the Missions situated near the Rio Tocuyo (NC-19, 10-70d; NC-19, 11-69d). From there he returned to Barcelona, passing again by Piritu. On 19 September he was back at Cumaná (see Map I). There he rested until December, recovering from a fever caught at Piritu.

His second trip (Map I), from Cumaná to the Rio Orinoco, can be only partially traced, from the data appearing in his "Species Plantarum observatae in itinere a Cumana die 17 Decembr. 1754, ad fluvium Orinoco, per Barcellonam \& Las Misiones de Piritu" (Loefling, 1758, 1957).

Leaving Cumaná on 17 December 1754, Loefling arrived in the next day at Barcelona, where he stayed until 8 January 1755 , making two excursions in the meantime to the "quinta" (small farm) of Miguel Roxas, on the 20th and 24th of December 1754. From Barcelona he left for San Bernardino (NC-20, 10-65d), 5 miles to the south, staying there from 19 to 22 January, when he went to El Pilar (NC-20,10-65d), returning to San Bernardino on the 27 th. There he stayed for two months (February and March), collecting around the city, and in the towns of Curataguiche (NC-20, 10-65d), Quiamare (NC-20, 10-65d), and Bergantin (NC-20, 10-64a). On 21 March he received a letter from Iturriaga with orders to abandon that region (designated by "Misiones de Piritu") and proceed to the Orinoco. Loefling started for that river, but the route he took is very difficult to trace, since, due to his sickness, the notes are very sparse and incomplete.

On 5 April he left San Bernardino, heading for El Pilar; the next day he passed by San Miguel (NC-20, 10-65d), San Francisco (NC-20, 10-65d), and the Rio Güere (NC-20, 10-65c) (7 April). From that point on, the route he took is unknown.

The next names appearing in his writings are Cupapui (NB$-20,8-62 \mathrm{c}$ ). Altagracia (NC-20, 8-62a). Suay (locality unknown to me), and some others, all situated to the south of the confluence of the rivers Caroni and Orinoco.

During his stay in the Mission of Santa Eulalia de Murucuri (locality unknown) Loefling suffered several attacks of intermitent fevers, followed by a Leucophlegmatia, and finally a Hydrops anasarca, in the words of Linnaeus (Anon., 1907; Rydén, 1957: 208). Loefling was transported to the Mission of Santo Antonio de Caroni (? San Antonio, NB-20, 8-63d), dying there on 22 February 1756. He was buried under an orange tree, near the church of the mission, wrapped in his own clothes. 


\section{PETRI LOEFLING \\ S. R. Mitis Hosper. B ientsi, Sue. Reg. Saiexs. Ufs. Sor. \\ ITER HISPANICUM, \\ ELLER

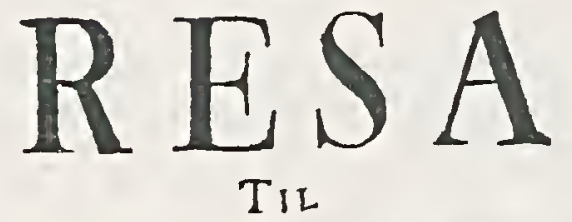

\section{SPANSKA LANDERNA}

UףI

EUROPA OCH AMERICA,

FORRÄTTAD IFRAN

År $1751 \mathrm{TIL} \AA_{\mathrm{R}} 1756$,

MED

BESKRIFNINGAR ocb RON

OFVER

$D E M A R K U A R D I G A S T E$ UAXTER

UTCIEVEN

Egter DESS Franfalle

\section{$A F$ \\ Carl Linneus.}

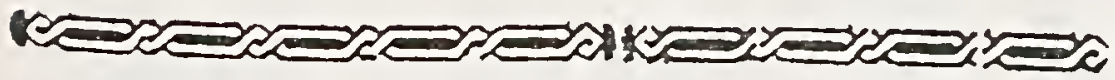

STOCKHOLM,

TRYCXT PI DIRECT. LARS SALVII KOSTNAD AR 1758 .

Title-page of Loefling's book of travels

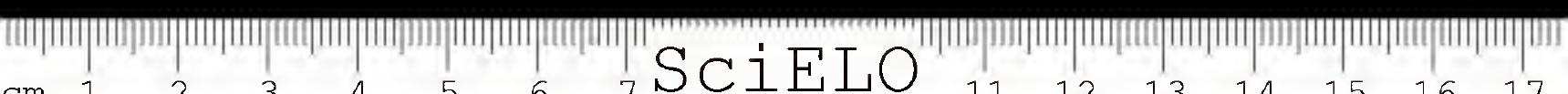
$\mathrm{cm} \quad 1$ 6 $\begin{array}{lllll}11 & 12 & 13 & 14 & 15\end{array}$ $16 \quad 17$ 


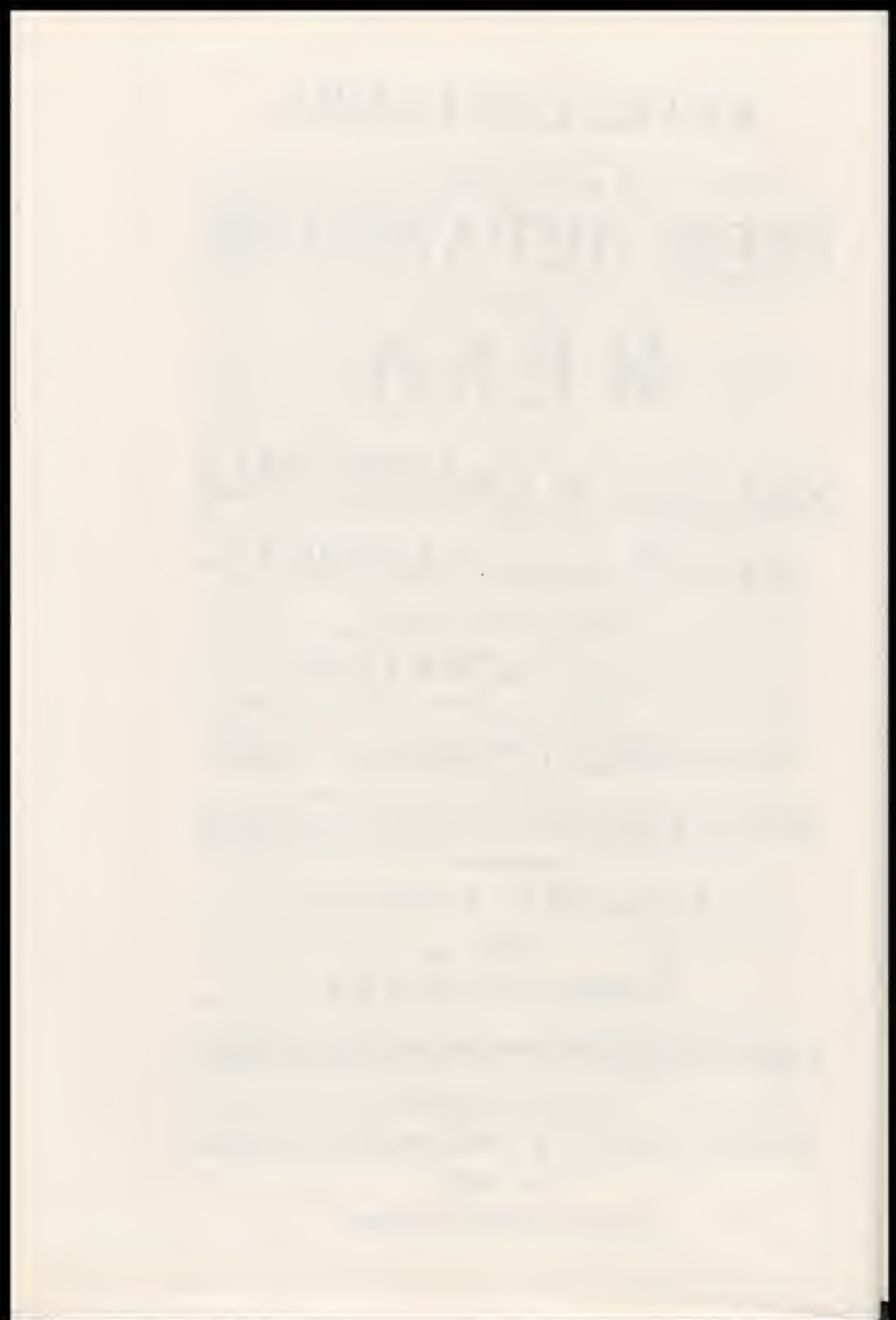

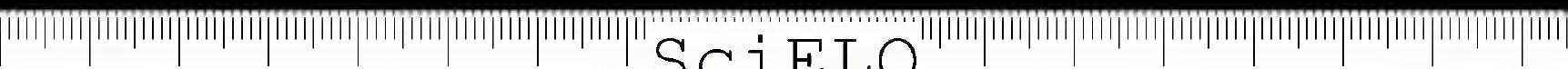

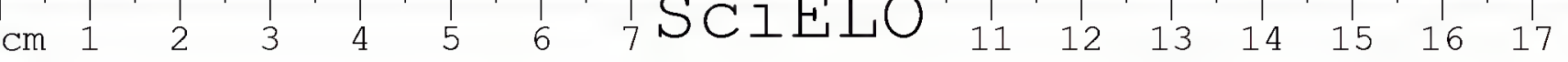


Lcefling's papers, containing many of his observations, descriptions of European and American plants, and his correspondence, were sent to the Jardin Botánico de Madrid, by order of Don Joseph de Iturriaga. There they were copied by one of the members of the Swedish Legation, Daniel Scheidenburg, who sent the manuscripts to Linnaeus, who edited and published them in 1758 . Loefling's original manuscripts are still preserved in the archives of the Jardin Botánico de Madrid.

Pehr Loefling, the first naturalist who collected Diptera in South America, contributed only one species (Tabanus occidentalis L.) to the Systema Naturae of his master, the tenth edition of which was published two years after Loefling's death.

\section{Dahlberg and Rolander}

In 1755 two other collectors arrived in South America: Dahlberg and Rolander.

Carl Gustay Dahlberg was born in Nyköping. Sweden, in 1721. In 1743, during the Finnish war, he served as a gunner in the Swedish army; in the same year he took part in the defense of Stockholm during the Dalecarlian revolt.

He went to Surinam as a corporal in the Dutch forces, arriving there probably at the end of 1746 with a letter of recommendation to the Governor General, J. J. Mauricius. On 3 May 1748 , Dahlberg was promoted to the rank of sublieutenant; he left the service on March 1752. While in Surinam, he married Johanna Catharina Bedloo, rich widow of Captain C. Brouwer, and became owner of the Brouwershaven plantations, with about 100 slaves, situated on the Perica $C$ reek, and the Carlsburg plantations, with about 40 slaves, on the Cottica River, and thus one of the wealthiest citizens of Surinam. From 19 November 1735 to $5 \mathrm{Fe}$ bruary 1754 (before his departure for Europe), he filled the important position of "Raad van Policie en Crimineele Justitie" (councillor of police and criminal justice). Eventually he obtained the military rank of "overst luitenant" (lieutenant-colonel). On 20 April 1754, Dahlberg left Surinam to visit Sweden. He was much interested in natural history and had made extensive collections, both zoological and botanical, which he donated to King Adolf Fredrick in 1754. By that time he had probably become acquainted with Linnaeus. He returned to Surinam in 1755 , taking Daniel Rolander with him.

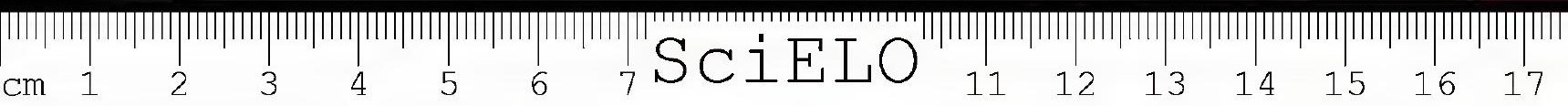


On 25 April 1761, Dahlberg left Surinam for a second time, this time accompanied by his wife and children. They visited Holland and Sweden: in Stockholm their third child was born. The family returned to Surinam on 20 March 1766. On 11 May 1771, Dahlberg and his wife went on a third trip to Europe; they stayed in Amsterdam and returned to Surinam on 9 July 1775. He never left Surinam again and died in Paramaribo in the afternoon of 6 September 1781.

Also in 1762 Dahlberg brought collections to Sweden. This material was donated to King Gustav III. Dahlberg's collections later went into the cabinet of King Gustav Adolf IV, including the 1754 donation, and are at present preserved in the Zoological Institute of Uppsala University. Dahlberg also appears to have donated Surinam materials to Empress Catherina of Russia, who in 1763 presented them to the St. Petersburg Museum (Holthuis, 1959).

Dahlberg's companion, Daniel Rolander, was born in Smaaland, Sweden, in 1726. He studied at the University of Uppsala, where Linnaeus showed his great confidence in Rolander by employing him as the private tutor of Carolus Linnaeus Jr.

During the ten years of his stay in Uppsala, Rolander published several entomological papers in the transactions of the Svenska Vetenskaps Akademien (Skjutflugan, 1750; Siktbiet. 1751; Hvit-ax masken, 1752; Beskrifning paa vägg-smeden, 1754; Anmärkningar öfver en bar larve med 16 fötter och tvädelta leder, som lefver af saafvel-mat, 1755) (Horn \& Schenkling, 1928).

Upon Linnaeus' request, Rolander joined Dahlberg on his return trip to Surinam. His trip was financed partly by Linnaeus, partly by the famous entomologist Baron De Geer. On 21 October 1754. Rolander left Uppsala for Amsterdam, whence he and Dahlberg sailed for Surinam, arriving in Paramaribo on 21 June 1755.

During his sojourn in Surinam, Rolander made many collecting trips in the neighborhood of Paramaribo $(\mathrm{NB}-21,6-55 \mathrm{c})$ and also went up the Commewijne River (NB-21,6-55d). The unrest caused by the revolt of the escaped negro slaves prevented him from penetrating deeper into the interior. He seems to have given most of his attention to botany, but collected many animals as well. His health became undermined by fever, aggravated by the fact that, according to the prevailing ideas about fever cures, he had to drink more alcoholic beverages than he was used to in his native country. Later, because of his poor health, he could not find the necessary strength to get rid of the drinking habit. After a stay of slightly more than half a year, he left 
Surinam on 22 January 1756. "For about six months he has looked around that world" (ungefär sex maanader har han koxat omkring i denna werld), Dahlberg wrote to Linnaeus (Paulin, 1951).

On his way home Rolander sailed to the Island of St. Eustatius (NE-20, 17-63b), in the Netherlands Antilles, arriving there on 23 February 1756. He stayed for ten days on the island, arranging his collections and gathering additional specimens. He reached Stockholm via Amsterdam on 2 October 1756.

$\mathrm{His}$ collections were excellent, and he had kept a diary with many careful notes. Rolander retained most of his collections while he was in Sweden; he sold part (or all?) of his insects to Baron De Geer. After a stay of some years in Sweden, Rolander went to Copenhagen. Here he sold a part of his herbarium to Professor Friis Rottböll. His diary, bearing the title "Diarium Surinamense, itinere exotico conscripsit Daniel Rolander", was acquired by C. G. Kratzenstein, who tried in vain to get it published. The Latin manuscript is now kept in the Botanical Central Library in Copenhagen, and consists of a large folio with about 700 pages. An article from this diary was published by F. Boie (1827).

From Copenhagen Rolander went to Landskrona, on the Swedish coast of the Sound, where Major-General Strussenfelt and a certain Mr. Schau took care of him. Strussenfelt instructed him to make an inventory of the animals and plants of the Island of Hveen, in the Sound, but the list produced was of very poor quality. After the death of Schau and the departure of Strussenfelt, Rolander went to Lund, where he lived, ill and in the greatest poverty, until his death in 1793 (Holthuis, 1959).

Linnaeus described the following species collected by Rolander in the tenth edition of the Systema Naturae: Musca leprae ("habitat in Elephantiasi Nigritarum Americae"), Tabanus exaestuans, T. fervens, T. mexicanus (sic), and T. antarcticus. Other species described by Linnaeus in 1758 from the "Museum De Geer", and probably collected either by Dahlberg or Rolander, are Musca illucens and Musca aequinotialis.

Carolus Linnaeus, Jr.

Linnaeus had made the University of Uppsala the most famous center of natural history in Europe. The years, however, were passing, and he was attacked by frequent illnesses. During 
those periods his son Carolus Linnaeus Jr., who had been born on 20 January 1741. was his substitute in the chair of botany. When Linnaeus Jr. attained his 18 th birthday, he was named demonstrator of botany in the Royal Gardens of Uppsala, and three years later (1777) he definitely replaced his father. His poor health, and a certain shyness prevented him from reaching the fame enjoyed by his father. He was happy with being an erudite and honest teacher, who consecrated his whole time to lectures and to the curatorship of the Royal Cabinet of Natural History.

Linnaeus Jr."s only paper published on zoology was the description of the "Oestrus hominis", based on a letter received from José Celestino Mutis, who had been sent by Charles III of Spain to Colombia, to study the natural history of the place (see letter of Humboldt to Bonpland, in Hamy, 1906: 224, dated 10 June 1805).

In this letter it is said that in Peru existed a fly which laid its eggs (transported on its abdomen) on the human skin, the worms penetrating it, and remaining there for half a year; if left alone, the worms would emerge by themselves, falling to the ground, and there they would transform into blackish flies, about the size of a housefly.

The story seemed so fantastic to Linnaeus Jr. that he wrote to Dru Drury a letter dated 10 March 1780 , concerning this strange fact: "Nuper litteras habui ex America Meridionali ubi morbus endemius est hominum etiam Europeos aggredit illuc venientes, quae causatur a larva OEstri, quae intra cutem per integrum annum coelatus et nullo remedio expelli potest nisi periculo vitae: est nova species OEstri."

In the following year he wrote a more detailed letter about the biology of the fly to the famous traveller and naturalist Peter Simon Pallas, naming the fly Oestrus hominis. The letter was printed by Pallas and became the original description of the species (see Guimarães \& Papavero, 1966).

On 10 January 1778, Linnaeus died. In his last will he had directed that his collections should be sold for the benefit of his daughters: he desired. however, that they should be acquired by the University of Uppsala. He gave his library to his son, who, after having paid his sisters for their share of the collections, remained the sole owner of the scientific collections and library.

After many disputes with his family, Linnaeus Jr. decided to sell the collections. J. G. Agrel. a friend of the family, who was responsible for the details of the sale, wrote concerning it to Sir 
Joseph Banks. The letter was received by Banks at a social meeting where a certain Mr. James Edward Smith was present. Although only 24 years old. Smith was the owner of a considerable fortune. Knowing the great value of Linnaeus' collections, and at the instance of Banks, Smith offered 1,000 guineas for them.

Two other offers were made - one by Baron von Alstroemer, and another by a Russian nobleman, authorized by Empress Catherina of Russia to offer an unlimited price for Linnaeus' collections.

Smith's proposal, however, was accepted, and the price of 900 guineas was agreed upon, Linnaeus Jr's own herbarium being excluded from the sale. The ship "Appearance" carried Linnaeus" colections to England in 26 large boxes in September 1783. The total cost of this acquisition, including all expenses of transportation, was 1,088 guineas and 5 shillings. The collections remained with Smith until his death, being afterwards bought by the Linnean Society of London, where they are still kept (Hoehne, 1942).

Linnaeus Jr. died in that same year, only 5 years after his father (Enc.).

\section{References}

Anonymous

1907. Homenaje á Carlos Linneo en el segundo centenario de su nacimiento, 1707-1778. Mem. Real Soc. Esp. Hist. Nat. 5 : xxxv +134 pp., pls. 1-4.

Boie, F.

1827. Ueber die Reinigung des Wassers durch Mückenlarven. Mitgetheilt von F. Boie aus des Verfassers Manuscript Diariun Surinamicum (befindlich in der Bibliothek des Botanischen Gartens zu Kopenhagen). Isis 20 (8) : 375-377.

Guimarães, J. H. E N. Papavero

1966. A tentative annotated bibliography of Dermatobia hominis (Linnaeus Jr., 1781) (Diptera, Cuterebridac). Arq. Zool., S. Paulo 14 (4) : 223-294, 2 pls.

Hamy, E. T.

1906. Aimé Bonpland, médécin ct naturaliste exploratcur de l'Amérique du Sud, sa vic, son oeuvre. sa correspondance, aucc un choix de 
pièces relatives à sa biographic, un portrait ct une catte, XCVI +300 pp., portrait, 1 map. Librairie Orientale et Américaine E. Guilmoto Éditeur, Paris.

Hoehne, F. C

1942. Notas bio-bibliograficas de naturalistas botânicos, in F. C. Hoehne, M. Kuhlmann \& O. Handro, O Jardim Botânico de São Paulo, 656 pp., illus. São Paulo.

Holthuis, L. B.

1959. The Crustacea Decapoda of Suriname (Dutch Guiana). Zool. $V \varepsilon r h .$, Leiden 44 : 1-296, 68 figs., map, 16 pls.

Horn, W. \& S. Schenkling

1928. Index literaturac entomologicae. Scric $I$ : Dic Welt-Literatur übet dic gesamte Entomologic bis inklusive 1863, 3 : xxI + pp. 705-1056, pl. 3. W. Horn, Berlin-Dahlem.

Linnacus, C.

1758. Systema naturac per ecgna tria naturac. Ed. x. Vol. $1: 824$ pp. Holmiac $[=$ Stockholm $]$.

Locfling, $P$.

1758. Petri Loefling iter hispanicum, eller Resa til Spanska länderna uti Europa och Amcrica, förrätad ifraan aar 1751 til aat 1756, med beskrifningat och rön öfver märkvärdigaste växter utgifven eftet dess fraanfaale af Carl Linnacus, xy + 316 pp., 2 pls. Stockholm.

1957. Plantae americanac, $127 \mathrm{pp}$. Instituto Ibero-Americano de Gotemburgo, Suecia. "Insula", Madrid. (Introduction and notes by Stig Rydén).

Marcgrav, G.

1648. Historiac rerum naturalium Brasiliac Libri viII, $124+300$ pp., illus. Amsterdam.

1942. História natural do Brasil, iv $+[12]+293+[5]+\mathrm{crv}$ pp. Imprensa Oficial do Estado, São Paulo (Edition organized by the Museu Paulista).

Merian, M. S.

1705. Metamorphosis insectorum Surinamensium, ofte Verandcring der Surinaamsche Insecten, waat in de Surinaamsche Rupfen en Wormen mit alle des zelfs Veranderingen na het leven afgcbeeld 
en besehreven worden, zynde clk geplaast op die Gewassen, Bloemen en Vruchten, daat sy op gevonden zyn; waare in ook de generatic der Kirkvorsehen, wonderbaren Padden. Hagedissen, Slangen, Spinnen en Mieren werden vertoond en beschreeven, alles in America na het leven en levensgroote geschildert en beschreeve, 60 pp., 60 pls. Amsterdam.

Pauliı, A.

1951. Sucnska öden i Sydamerika, 618 pp., illus. P. A. Horstedt E Söners Förlag, Stockholm.

Piso, G.

1658. De Indiac utriusque te naturali et medica libri xIv, 327 pp., illus. Amsterdam.

1948. História natural do Brasil ilustrada, $\mathrm{xx}+434$ pp., illus. Companhia Editôra Nacional, São Paulo (Edition organized by the Museu Paulista).

Rydén, $S$.

1957. Pedro Locfling en Venezucla (1754-1756), 266 pp., illus. Instituto Ibero-Americano de Gotemburgo, Suecia. "Insula", Madrid.

Serrano, J.

1922. Historia Geral, pp. 763-874, in Instituto Historico c Geographico Brasileiro, Diccionario Historico, Geographico e Ethnographico do Brasil 1 : 1688 pp., illus. Rio de Janeiro. 


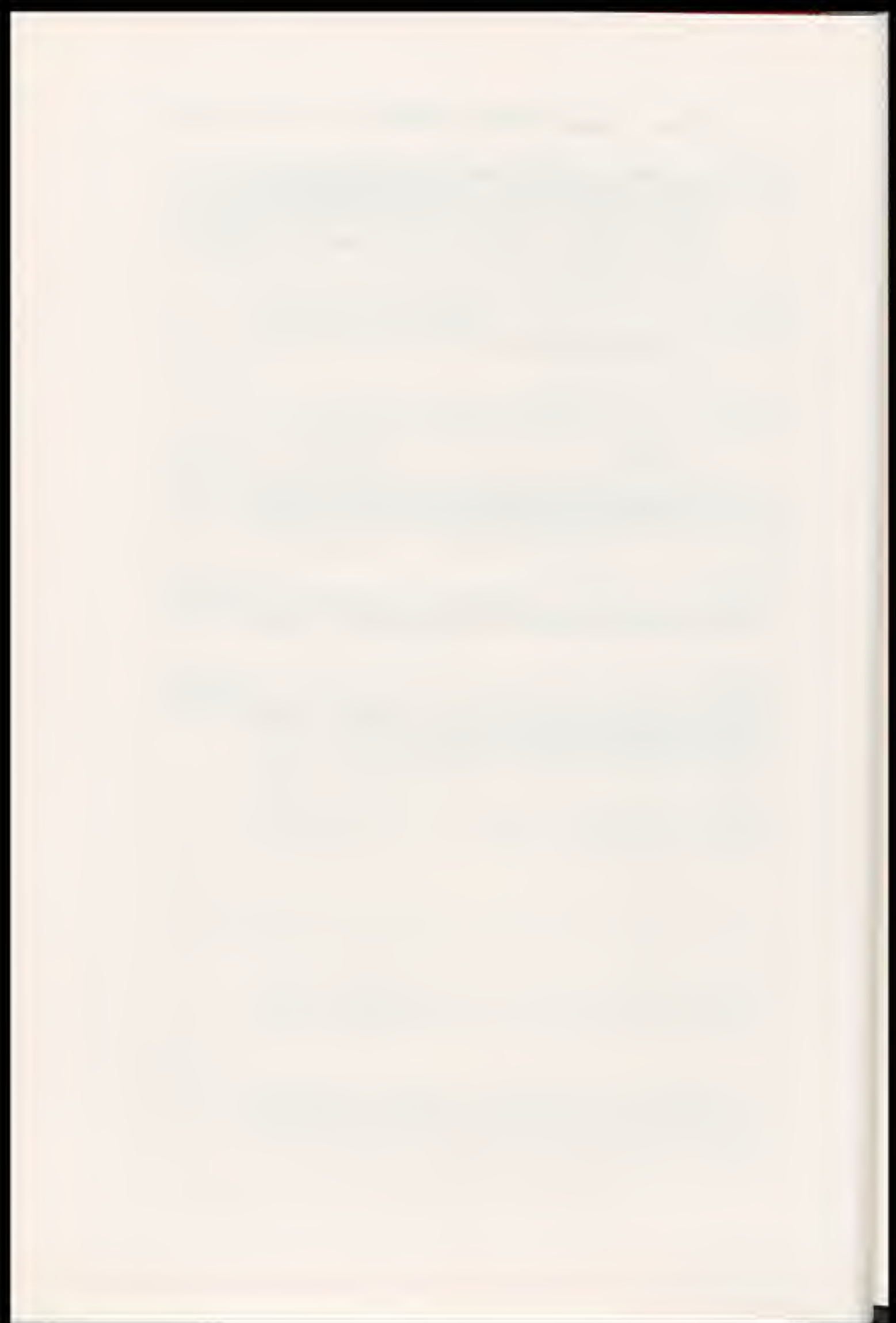

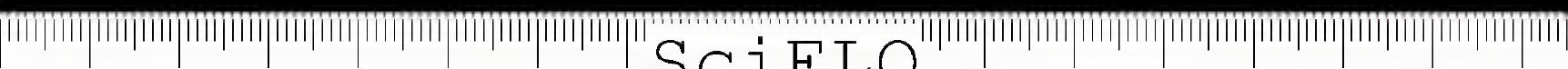

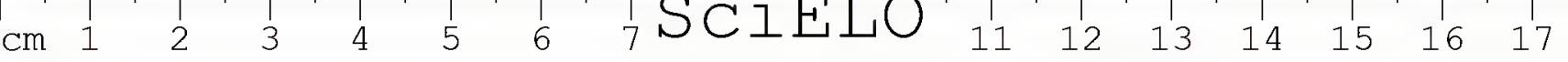




\section{Chapter II}

\section{The period of Fabricius}

The eruise of the «Endeavour»

The Royal Society of London decided to send astronomers to the Southern Sea to observe a passage of Venus over the disk of the sun, which was to occur, according to the calculations of the time, in June 1759. The Island of Tahiti was finally chosen as the most appropriate for the operation.

The Royal Society submitted to His Majesty the King of England, in 1768, a petition for an expedition. The monarch agreed and notified the Lords of the Admiralty of his wish to equip a ship to send the astronomers and other scientists to places to be determined by the Royal Society. In April, the Secretary of the Admiralty advised the Society that the 370 ton ship, the "Endeavour", was ready to sail, under the command of Captain James Cook, whose knowledge both of astronomy and navigation was highly commendable.

On 27 May 1768, Cook took command of the "Endeavour" in the Bay of Deptford. After loading with food stores and ammunition, the ship sailed for Plymouth. Then, in the middle of August, when the naturalists of the expedition, Joseph Banks and Daniel Solander were aboard, she sailed for the Southern Sea. Joseph Banks was born in London, on 13 February 1743. He studied at Harrow College and Christ's College, and obtained 
his M. A. degree in the University of Oxford (1760-1763). His father's death in 1761 left him the master of a great fortune, which he employed in the study of natural sciences. Banks studied the works of Linnaeus and Buffon assiduously, made an extensive herbarium of the British flora, and built one of the largest and most famous libraries of natural history in Europe. In 1766 he went on a collecting trip to Newfoundland and Labrador. Encouraged by his success on that trip, he joined Cook's expedition, contributing financialy to it, and bringing with him two artists, Parkinson and Buchan, to draw landscapes and natural history specimens. Upon his return to England, Banks was elected Fellow of the Royal Society, being made its President in 1778. He was knighted in 1781, and made a member of the French Academy of Sciences in 1802. He died on 19 June 1820 in Spring Grove, Isleworth, Middlesex, England (Enc.).

Daniel Solander, born on 12 February 1733, in Piteaa, Province of Nordland, Sweden, was one of Linnaeus' disciples. He studied medicine at the University of Uppsala in 1750; in 1753 he explored the Alps of Lapland and visited the regions between Archangelsk and St. Petersburg, and also collected in the Canary Islands. Coming to England in 1760, he arranged the Museum of Portland, composed the catalogue of the collections of the British Museum, and in 1765 was appointed assistant librarian of the same institution. He joined Cook's expedition as naturalist, botany being his major interest. When he returned to England, he served as secretary to Sir Joseph Banks, and in 1772 made another journey, this time to Iceland. In 1773 he was made curator of the British Museum. He died on 13 May 1782 in London.

The "Endeavour", after short stops at Madeira, Teneriffe, and Cape Verde, arrived at Rio de Janeiro on 13 November 1768. Banks and Solander were anxious to collect in the neighborhood of the city, but the Viceroy, D. Antonio Álvares, Count da Cunha, for unexplained reasons, permitted only Cook and a snall part of the crew to land. Several misunderstandings happened between Cook and the Viceroy, and only on the 26th Mr. Banks, after artfully eluding the vigilance of the Viceroy's guards, went ashore, making collections of natural history, with which he returned to the ship. On the previous day, a monk had asked for a surgeon of the ship, and Solander had thus the occasion to land.

On 5 December, the "Endeavour" was moored in the Ilha Rasa ("Brasilia, Dom. Banks" of Fabricius) (SF-23, 43-23c). off the entrance of the Bay of Guanabara, where Banks and So- 


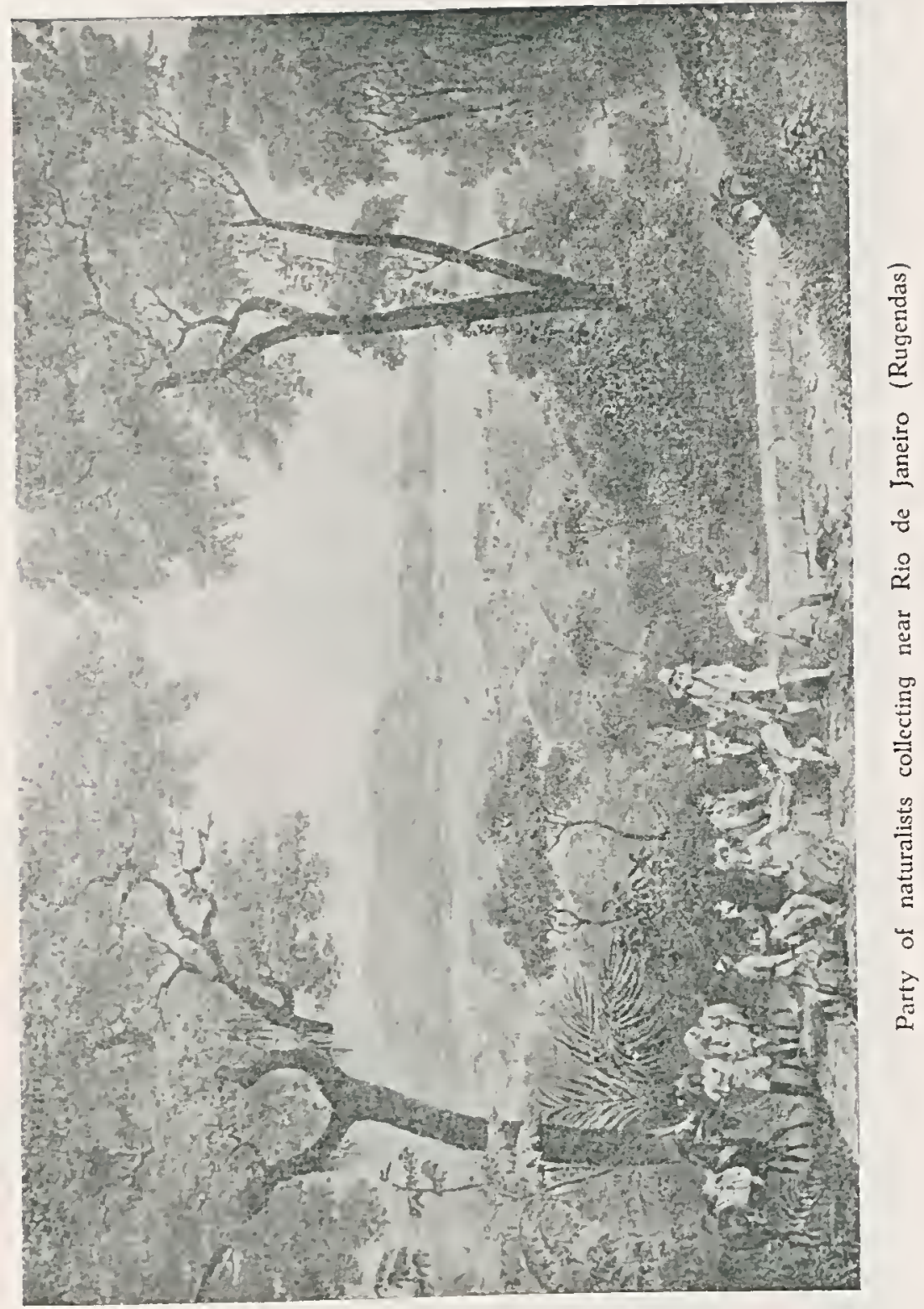


lander had the chance to make natural history collections. They stayed there until 8 December 1768, when the "Endeavour" sailed for Cape Horn.

On 11 January 1769, they passed the Falkland Islands. On the 14th they entered the Strait of Lemaire, and about noon passed between the Capes of San Diego and San Vicente (SN-19, 55-65a), and anchored near the latter. Banks and Solander went ashore for a few hours, and returned with more than one hundred different plants and flowers. On the 15 th they landed in the Bay of Good Success (Bahia Buen Suceso, SN-19, 55-65a); next day the two naturalists, together with the surgeon Mr. Monkhouse, the astronomer Mr. Green, the artist Mr. Buchan, several other people, and accompanied by servants, went ashore for a botanical exploration. Although they were able to collect several plants, the expedition was hampered by the tremendous cold of those antarctic regions, and its members almost froze to death. But finally they were able to return to the "Endeavour" on the 17 th. On the 20th the naturalists made another excursion into the country, collecting plants and molluscs, and went to visit an Indian village. In that same day Captain Cook weighed anchor, and after crossing Cape Horn the "Endeavour" sailed for Tahiti (Anon., 1906; Banks, 1896; Banks E Solander, 1793; Cook, 1804).

\section{C. M. Richard}

In 1781 Necker and Castries desired to send to French Guiana a man able to study the botany of that colony and find new plants that might prove useful to agriculture. The French Academy of Sciences recommended Louis Richard.

Louis Claude Marie Richard was born in Auteuil, France, on 4 September 1754. His family was traditionally interested in botany, and his father, Claude Richard, was head of the Royal Gardens at Auteuil. Young Richard could draw excellently and also knew Greek and Latin. The Archbishop of Paris, M. de Beaumont, who frequently visited the gardens of Auteuil, became greatly interested in the boy and suggested that he join the Church, in order to further pursue his studies, since as the son of a mere gardener he would not have the funds necessary to make himself a career. This proposal, however, did not interest Richard. This so scandalized his father, that he banished him from home. At the age of only 14 years Richard left Auteuil for Paris, where he lived in the Quartier Latin. An architect gave him plans of gardens to draw, by which means he made his 
living. The beauty and accuracy of his drawings not only guaranteed his survival, but gave him a decent living and enabled him to accumulate 80,000 livres.

In Paris he attended the lectures at the Collège de France and at the Jardin du Roi, and was soon known as a skilled botanist. His nomination to go to French Guiana met with the approval of King Louis XVI, who personally showed him a chart of that possession, indicating points worthy of investigation, rivers to be mapped, etc.

Richard left France in 1781, and for a few years collected in Cayenne (NB-22, 5-52c) and other parts of French Guiana. In 1785 he had the opportunity of going to Belém (SA-22, 1-48c; SA-23, 1-48d), in Brazil, where he gathered several species of plants to be introduced into Cayenne. In 1786 he went to the Antilles, visiting Martinique (ND-20, 15-61d), Guadeloupe (NE20, 16-62b). Antigua (NE-20, 17-62b), Barbuda (NE-20, 18 -62d). Anguilla (NE-20, 18 63b). St. Croix (NE-20, 18-65d), Tortola (NE-20, 18-65b). St. John (NE-20, 18-65b). St. Thomas (NE-20, 18-65b). Puerto Rico and Haiti, returning to Cayenne in November 1789. He made extensive collections of plants, animals, and minerals, and excellent drawings of objects of natural history.

Meanwhile, in France, the Revolution had begun. Louis XVI and Marie Antoinette were practically prisoners. Richard, due to his relations with Minister Necker, was in a difficult position as royal botanist, and had some misunderstandings with the governor of Cayenne. He decided then to return to France, although very uncertain as to what he would encounter there.

He landed at Le Havre. Because of the upset political situation he was not reimbursed for the great expenses made during his voyages, which had been paid out of his own savings, and had to return to the same way of living as draftsman, until 1795, when Fourcroy, establishing the School of Medicine, made him professor of botany. He died on 7 June 1821, at the age of 67. "d'un catarre sur la vessie" (Cuvier, 1825; Urban, 1903).

According to Latreille (1811: 127-128): "Mr. Richard, membre de l'Institut, et que son zèle pour l'avancement de l'histoire naturelle conduisit dans les retraites presque inacessibles de la Guyane françoise, y avoit ramassé en peu de temps, et quoique ses recherches ne fussent que sécondaires, près de six mille espèces d"insectes" (italics mine).

A manuscript with Richard's observations made in St. Croix (1786) and St. Thomas $(1786-1787)$ is preserved in Paris. 


\section{Palisot de Beauvois}

Ambroise Marie François Josephi, Baron de Palisot de Beauvors, was born at Arras, France in 1752, and died in Paris in 1820. He had been successively musketeer, "avocat" in the Paris Parliament (1772), and "réceveur général des domaines et des bois" in Picardy, Flanders and Artois, when, in 1777, he decided to derote himself to the study of natural history. In 1786 he accompanied a black prince of Oware back to Africa, and explored as naturalist the Kingdoms of Oware and Benin, making a great collection of plants and animals. Ill with malaria, he left Guinea aboard a French ship, and went to Santo Domingo (via Cayenne ?).

At that time there were several rebellions on the island. On 28 March 1790, the French "Assemblée Nationale", inspired in the principles of the Revolution, had decreed that in French colonies mulattoes and free negroes would have their citizenship and the same rights as the whites. The latter, who wanted to get rid of the colonial system, had refused to share their prerogatives with the free negroes. These revolted, with the help of the slaves, and the situation in the island was very dangerous.

In spite of all, Palisot de Beauvois, who had recovered his health, collected insects in that turbulent region. It is difficult to know at present whether he collected in the French portion of the island (nowadays Haiti) or in the Spanish portion (now the República Dominicana).

Palisot de Beauvois was appointed, in 1790, a member of the Superior Council of the Cape, and a member of the Second Colonial Assembly. This latter body sent him in 1791 to Philadelphia, to seek help against the rebellious negroes of Santo Domingo. When he returned in 1793, the rebels imprisoned him, but a negress whom he had set free saved his life. In the same year slavery was abolished, and the Act was ratified by the French Convention of 1794.

The naturalist returned then to Philadelphia, where he had to earn his living teaching music and languages. The Chargé d'Affaires of France, M. Adet, obtained for him funds for a scientific collecting trip through North America. He returned to France in 1798. In 1806 he was appointed a member of the Institut de France, and in 1815 a member of the University Council (Enc.). From 1805 to 1821, he published the descriptions of 
the insects he had collected in Oware, Benin. Saint-Domingue and the United States (see Palisot de Beauvois, 1805-1821).

\section{A. G. Bosc}

Louis Augustin Guillaume Bosc, son of Paul Bosc d'Antic, was born in Paris on 29 January 1759 and died in Paris on 10 July 1828. He filled several administrative posts ("Sécrétaire des postes", from 1784 to 1788 , director of the same under Roland's ministry), but continued his studies of natural sciences. During the Terror he had to leave Paris and hide in the forest of Montmorency, becauce of his relations with Roland and the Girondins. After the 9 Thermidor (27 July 1794) with the fall of the Terror, and the execution of Robespierre, Bosc reappeared in Paris, and under the "Directoire" he left for America (New York) as French Consul. In the New World he collected numerous specimens which went to enrich the works of Lacépède, Latreille, and Fabricius. He must have collected also in Cayenne, as said by Fabricius in the "Systema Antliatorum", but this could be Fabricius" mistake. Bosc was appointed in 1803 inspector of the Gardens of Versailles, and in 1806 inspector of the Gardens under the jurisdiction of the Ministry of Interior; in 1825 he replaced Thouin as "professeur" in the Jardin des Plantes. He was a close friend of Fabricius. His collections were placed in the Muséum National d'Histoire Naturelle (Enc.).

\section{J. P. B. von Rohr}

Julius Philip Benjamin Von RoHr (1735-1793) was born in Merseburg on the Saale, Prussia. He began his studies of natural history and medicine in Halle, and finished the medical studies in Copenhagen. He went to the West Indies for the first time in 1757, as "naturalista regius", but the collections of specimens he sent to Denmark were lost at sea. His financial circumstances were strait at the time of his first visit: however, they greatly improved in 1765 , and he was appointed architect. with the rank of captain, in connection with the fortification of the Island of St. Croix (NE-20, 18-65d), then a Danish possession. In 1783, by order of the Government, he made a zoological journey to Jamaica, Puerto Rico, and the Lesser Antilles, and to the nearest countries along the Caribbean coast of South 
America, eastward to the Guianas (Cayenne). From this journey he sent home a large collection of insects. During this period he also founded a botanical garden in St. Croix. He was interested in botany, especially in useful plants, and published a book on cotton (Henriksen, 1921-1937; Pennel, 1945; Zimsen, 1964).

«Smidt»

Concerning "Smidt", whose name is the one most frequently cited in Fabricius' works, very little is known.

Ella Zimsen (1964: 14) makes the following comments: "In Fabricius' later works the insects from the West Indies are very often mentioned from Smidt. On old-preserved original labels from Sehestedt and Tönder Lund's collections the name is spelled Schmidt. In the 1780's there lived a customhouse officer, Adam Levin Smidt, and a surgeon, Johann Christian Smidt, both of them employed on St. Croix. It is not certain who is meant."

On the other hand, we find in Staal's "Hemiptera Fabriciana" (1868: 3) the following notice about Smidt (kindly translated by George C. Steyskal):

"Most of the numerous South American species that Fabricius described and for which a certain SmidT is cited as collector, are found only in the Copenhagen Museum, in Tönder Lund's and Sehestedt's famous collections, as well as a small part in Fabricius' own collection, which now belongs to the University of Kiel. The only information we have, kindly supplied by Prof. Schjödte, on Smidt (or Schmidt, as his name is written in the Copenhagen Museum and by Tönder Lund) is that he visited, besides several West Indian islands, certain places on the South American mainland, such as Essequibo and Demerara in the present British Guiana (italics mine); therefore, all of the South American species cited as having been collected by Smidt can with certainty be considered as coming from the vicinity of the named localities, and this is just what one who is familiar with American Hemiptera and their distribution immediately perceives."

From the collection brought in by Smidt Fabricius described more than 150 species in his "Systema Antliatorum".

The localities of Demerara River (NB-21,7-58c) and Essequibo River (NA-21, 4-58c; NB-21, 7-59d), referred to by Staal, are confirmed by the examination of Fabricius' types by Moure, 
who states (1960: 98): "In the Copenhagen collection the specimens of Formica of 'Smidt America Meridionalis' (Schmidt on the labels) are labelled from Essequibo River, British Guiana".

\section{Pflug and Yeats}

On the last two collectors who obtained insects for Fabricius we have very meager information. Paul GotTfried Pflug (1741-1789) went to Denmark in 1763, became a surgeon and gave lectures in medicine to students. In 1784 he obtained his doctor degree in Kiel and in 1785 travelled to the West Indies (perhaps a ship's doctor?), collecting especially in St. Croix. He also travelled to Sierra Leone and China. He died in 1789 in St. Croix. Thomas Parkinson Yeats (sometimes wrongly spelled "Yates" by Fabricius), author of "Institutions of Entomology, being a translation of Linnaeus' Ordines et Genera Insectorum, or systematic arrangement of Insects (London, 1773)", collected in (or received collections from?) Jamaica.

\section{References}

Anonymous

1906. Captain Cook's voyages of discovery, $1 \mathrm{x}+479$ pp. Everyman's Library Series, J. M. Dent $\mathcal{E}$ Co.. London; Dutton \& Co., New York.

Banks, J.

1896. Journal of the Right Hon. Sir Joseph Banks during Captain Cook's first voyage in H.M. S. Endeavour in $1768-71$ to Tierra del Fuego, Otahite, New Zealand, Australia, the Dutch East Indies, etc. (edited by Sit Joseph D. Hooker), 406 pp., 2 pls., 4 maps. Mac Millan \& Co. Lid., London \& N. York.

Banks, J. \& D. Solander

1793. Voyage de $M$. de Bougainville, contenant le journal d'un voyage autour du monde, fait par MM. Banks \& Solander. Angiois, en 1768, 1769. 1770, 1771 (traduit de l'Anglois par M. de Fréville) 3 : XII +360 pp. Gay \& Gide, Libraires, Paris.

Cook, J.

1804. Premier voyage de James Cook autour du monde, fait en 1768, 1759. 1770 et 1771, précédé des relations de MM. Byron. Carteret et Wallis, 2 : 254 pp. Veuve Lepetit, Paris. "An XII". 
Cuvier, $\mathrm{G}$.

1825. Eloge historique de M. Richard. Mém. Mus. Hist. Nat. Paris 12 : 349-366.

Henriksen, K. I.

1921-1937. Oversigt over Dansk entomologis historiae. Ent. Mcddel. 15 (1) : 1-48; (2) (1922) : 49-96; (3) (1923) : 97-144; (4) (1925) : 145-192; (5) (1926) : 193-240; (6) (1927) : 241-288; $(7-8) \quad(1936) \quad: \quad 289-384 ; \quad(9-10) \quad(1936): 385-480 ; \quad(11-12)$ (1937) : 481-578, 154 figs.

Latreille, P. A.

1811. Insectes de 1'Amérique Equinoxiale, recueillis pendant le voyage de MM. de Humboldt et Bonpland, pp. 127-252, in A. von Humboldt $\&$ A. Bonpland, Recueil d'observations de zoologie et d'anatomie comparéc, Vol. 1.

Moure, J. S.

1960. Notes on the types of the neotropical bees described by Fabricius (Hymenoptera : Apoidea). Studia Ent. 3 : 97-160.

Palisot de Beauvois, A. M. F. J.

1805-[1821]. Insectes recucillis en Afrique et en Amérique dans les Royaumes d'Oware et Benin. à Saint-Domingue et dans les ÉtatsUnis, pendant les annécs 1786-1797, pp. I-XCI + 1-24, 6 pls. $(=$ livr. 1), 1805; pp. 25-40, 6 pls. (= livr. 2), [1805]; pp. $41-56,6$ pls. (= livr. 3), [1806]; pp. $57-72,6$ pls. (= livr. 4), [1807]; pp. 73-88, 6 pls. (= livr. 5), [1807]; pp. 89-100, 6 pls. (= livr. 6), [1809]; pp. 101-120, 6 pls. (= livr. 7), [1811]; pp. 121-136, 6 pls. (= livr. 8), [1811]; pp. 137-156, 6 pls. (= livr. 9), [1817]; pp. 157-172, 6 pls. (= livr. 10), [1817]; pp. 173-190, 6 pls., (= livr. 11), [1818]; pp. 191-208, 6 pls. (= livr. 12), [1818]; pp. 208-224, 6 pls. (= livr. 13), [1819]; pp. 225-240, 6 pls. (= livr. 14), [1820]: pp. 241-276, 6 pls. (= livr. 15, by J. G. A. Serville), [1821]. Paris, "1805". [The plates are not numbered consecutively. The 3 plates for Diptera are in livraisons 3,6, and 13].

Pennell, F. W.

1945. Historical sketch, pp. 35-48, in F. Verdorn, ed., Plants and plant sciences in Latin America, 381 pp., illus. Chronica Botanica Co, Waltham, Mass.

Richard, L. C.

(1786-1787). Carncts de notes de voyages aux Antilles: Observations prises à Sainte-Croix (1786) - Varia in insula Sancti Thomae observatae (1786-1787), (MS 1608, Bibliothèque du Muséum Na. tional d'Histoire Naturelle, Paris). 
Stảl, C.

1868. Hemiptera Fabriciana. Fabricianska Hemipterarter efter de i Köpenhamn och Kiel förvarade typenexemplaren granskade och beskrifen. Kongl. Suenska Vetensk. Akad. Handl. 7 (11) : 1-130.

Urban, I.

1903. Notae biographicae peregrinatorum Indiae occidentalis botanicorum, in his Symbolae Antillanae 3 (1) : 14-158. Lipsiae (= Leipzig).

1908. Vitae itineraque collectorum botanicorum, notae collaboratorum biographicae, Florae Brasiliae ratio edendi chronologica, systema, index familiarum, pp. 1-Cx, in C. F. P. von Martius et al., Flora Brasiliensis, enumeratio plantarum hactenus detectarum quas suis aliorumque botanicorum studiis descriptas partim icones illustratas 1 (1) : $\mathrm{CX}+266+31$ pp., 59 pls.

Zimsen, E.

1964. The type material of I. C. Fabricius, 656 pp. Munksgaard, Copenhagen. 
Chapter III

\section{The life and works of J. C. Fabricius}

Johann Christian Fabricius was born in Tönder, South Jutland (then and now in Denmark, but German from 1864-1920) on the 7 th of January 1745. His father, J. C. Fabricius, was the physician appointed by the Government to that city and its county; his mother's name was Anne Henningsen; an elder brother and Johann Christian were the only children they had. His' father educated him in a spirit of liberality and freedom uncommon in those days. Fabricius learned drawing, dance, and music. In his father's library he found Linnaeus' Species Plantarum, in which he found "pleasure in reading", and when he was fourteen or fifteen years old he made an extensive analysis of Pontoppidan's Natural History of Norway.

In 1761 his father was appointed physician to Frederik's Hospital in Copenhagen, and sent him to Altona (then in Denmark) to be prepared for college. In 1762 Fabricius went to Copenhagen. In the autumn of the same year his father sent him to Uppsala, where he remained for two years. There, he said, his "Future destiny appears to have been laid" (Hope, 1845). From Linnaeus he learned the "systematic order with which the study of sciences ought to be pursued", and began to study insects. In Uppsala he formed a friendship with Thunberg. In 1764 he returned to Copenhagen, where he remained during the 
winter. There he laid the foundations of his "Systema Insectorum", and compiled the "Genera Insectorum", based on the small collection he then possessed.

In 1765 , through his father's influence, he went to Leipzig, to hear the lectures of Professor Schreber on economy. His brother went at the same time to Leyden, where Siegfried Albin was teaching anatomy. Fabricius was zealously engaged in writing his "Entomologia", and in collecting plants and insects of the neighborhood. On his vacations he visited Freiburg and Dresden.

In 1766 he went to Leyden, where he attended the lectures of Gaubius on chemistry and those of Allemand on "natural philosophy". He also went to Amsterdam, the Hague, and Delft, where he examined and described the several collections of insects to which he was able to obtain access.

In the spring of 1767 he went by sea from Amsterdam to Edinburgh, where he met his brother, who introduced him to Cullen, Gregory, Young, and Hope. As soon as Fabricius had in some degree acquired the language, he bought himself a horse and travelled through the Highlands. He visited several parts of the country, gathering insects and plants, and in the beginning of September he and his brother went through the western part of England to London, arriving there in November. In London Fabricius had "the good fortune" of forming an intimate acquaintance with the Swedish botanist Daniel Solander, at that time located at the British Museum. Solander introduced him to the scientific clubs and to Joseph Banks, Hunter, Drury, and others, whose houses and libraries and collections were soon opened to him. He determined and described the insects, and his "Systema Entomologiae" gained ground considerably, as well as his insect collection, which was sent to Copenhagen.

During the greatest part of 1768 he remained in London. In June, Banks and Solander went on their expedition round the world with Captain Cook, aboard the "Endeavour". Their absence "made London appear (...) as if it were empty", said Fabricius. At the end of the year he left London and went to Paris, which he left in December, travelling through Lyons, Nimes, Marseille, Montpellier, Antibes, and, passing to Italy, through Nice, Como, Torino, Milano, Verona, and Padua, reached Venice. During this journey he became acquainted with the naturalist Allioni. At Padua he met Vallisneri, and from Venice he made a short trip to Bologna to examine the collections of Aldrovandi. Very early in the spring he went by Laybach to 
Idria, to get acquainted with the famous entomologist Scopoli. From Idria he crossed the Tyrolean mountains, visiting Innsbruck, Halle, and passed through Munich, Regensburg, and Stuttgart. From Tübingen he travelled through part of Switzerland to Strasburg, and after remaining some weeks there, travelled to Hamburg, and returned at the end of autumn to Copenhagen.

In 1768 he was again appointed to a professorship at the Charlottenborg-Institution of Natural History in Copenhagen, with permission to travel for another two years, but when he finally returned, his professorship was transferred to the University and the salary very much reduced. In the autumn of 1769 he travelled through Schleswig and Holstein, and in the winter, after his return, he commenced lectures on political economy. His salary at that time was 400 rigsdaler. In 1771 he married the daughther of "Cancelieraad" Ambrosius of Flensborg, by whom he had two sons.

In 1773 he published his work "Anfangsgründe der ökonomischen Wissenschaften, zum Gebrauch akademischer Vorlesungen." From 1772 to 1775 he spent the winters in Copenhagen and the summers in London. His friends Banks and Solander had returned from their voyage around the world, and had brought numerous specimens of natural history, especially insects. With Banks, Hunter, and Drury, Fabricius found plenty to engage his time.

He left Copenhagen in 1775 to accept an offer, made by Canzler Cramer, of a professorship of natural history, economics and finances at Kiel, which was then Danish, with a salary of 650 rigsdaler, but again his justified expectations were disappointed; he dit not get the necessary facilities for work. He missed there the use of good collections, being exclusively limited to his own.

During Easter his "Systema Entomologiae" appeared. In 1776 he published the "Genera Insectorum" and in 1778 the "Philosophia Entomologica".

In the summer of 1778 he joined Professor Weber in an excursion to Norway. That gave rise to the publication of his "Reise nach Norwegen" (Hamburg, 1779). In 1780 he went once more to England, and wrote his "Von der Volks-Vermehrung, insonderheit in Dännemark", which appeared in 1781, and in that same year his "Betrachtung über die Einrichtungen der Natur".

In 1781 the two volumes of the "Species Insectorum" appeared, as a continuation of his "Systema". As there was at that period a prospect of his getting an appointment in England, 
and, in consequence of his family increase he found his salary insufficient, he tended his resignation.

This caused his government to add to his annual stipend 200 rigsdaler, bringing it up to 850 rigsdaler, so he remained in his professorship. In the summer he made a trip to England. In 1783 he published his "Briefe aus England", in 1784 "Von der die Erziehung insonderheit in Dännemark". In 1784 there appeared "Cultur der Gewächse" ("Sanders Naturgeschichte für den Landmann, 4ter Theil"). In the summer he travelled with his family through most of the provinces of Germany to Vienna. On the way thither he visited Leipzig. Dresden, and Prague, where he renewed some old acquaintances and formed new friendships. In the autumn he returned to Nurenberg, Erlangen, Mannheim, Frankfurt, Cassel, and Göttingen. In 1786 he went to St. Petersburg, then returned to Copenhagen and published in 1787, his "Mantissa Insectorum". In the summer he went again with all his family to England.

In 1789 he requested his dismissal from the University which was granted, with a pension of 400 rigsdaler but he withdrew his petition and remained as professor. In 1790 he travelled with his wife and daughter to Paris, partly because he knew, from Olivier, that the Parisian cabinets contained a considerable number of insects with which he was unacquainted, and partly because, as an economist and politician, he wished to be fully informed about the new order of things which had been introduced by the Revolution. He was received by some of the leaders of the Revolution, especially the family Roland, and was distinguished with the friendship of Desfontaines, Jussieu, Bosc, Fourcroy, Olivier, and others, who opened to him all their collections.

At midsummer, 1791, he returned by England to Kiel, but went almost immediately to Copenhagen. Two years afterwards his daughter died. From 1792 to 1794 appeared the "Entomologia Systematica" in six volumes. In 1794 he was obliged, on account of his wife's health, to leave Kiel and travel to Switzerland. They went by way of Jena, where both Fabricius' sons were studying, Coburg, and Bamberg, to Erlangen, proceeding then through Nurenberg, Augsburg, Lindau and St. Gallen, to Winterthur, Zürich, Lucerne, and, through the republican cantons, back again to Zürich; afterwards they journeyed along the Rhine, by Frankfurt and Cassel, and at the close of the year were again at Kiel. In that same year Fabricius took his wife to Paris, whence she never returned and so in the autumn he returned alone to Kiel. In the following years he visited his wife in Paris, and again returned to Kiel. In 1798, after the publication of the 


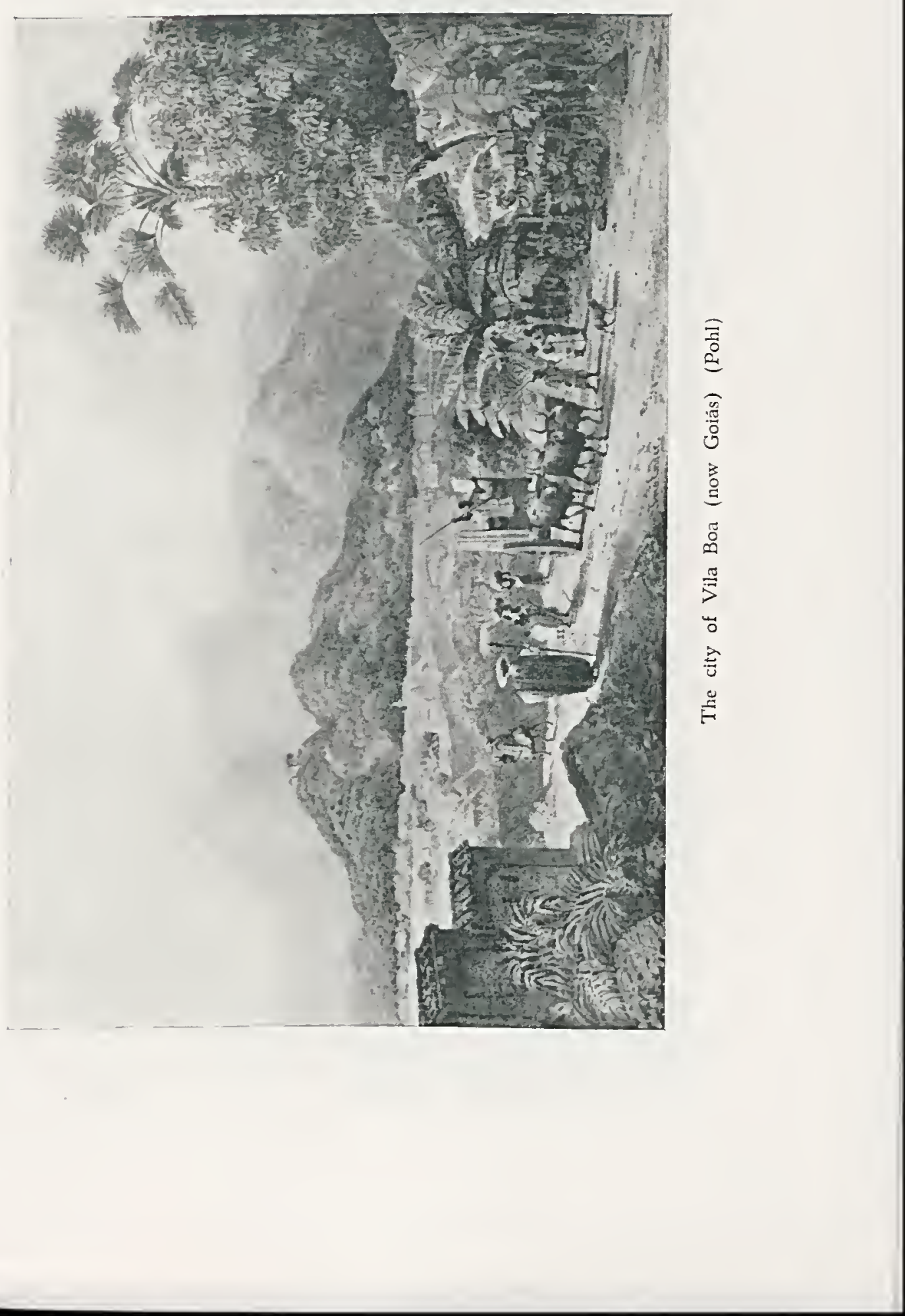

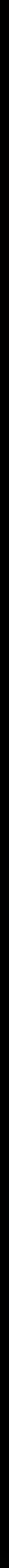




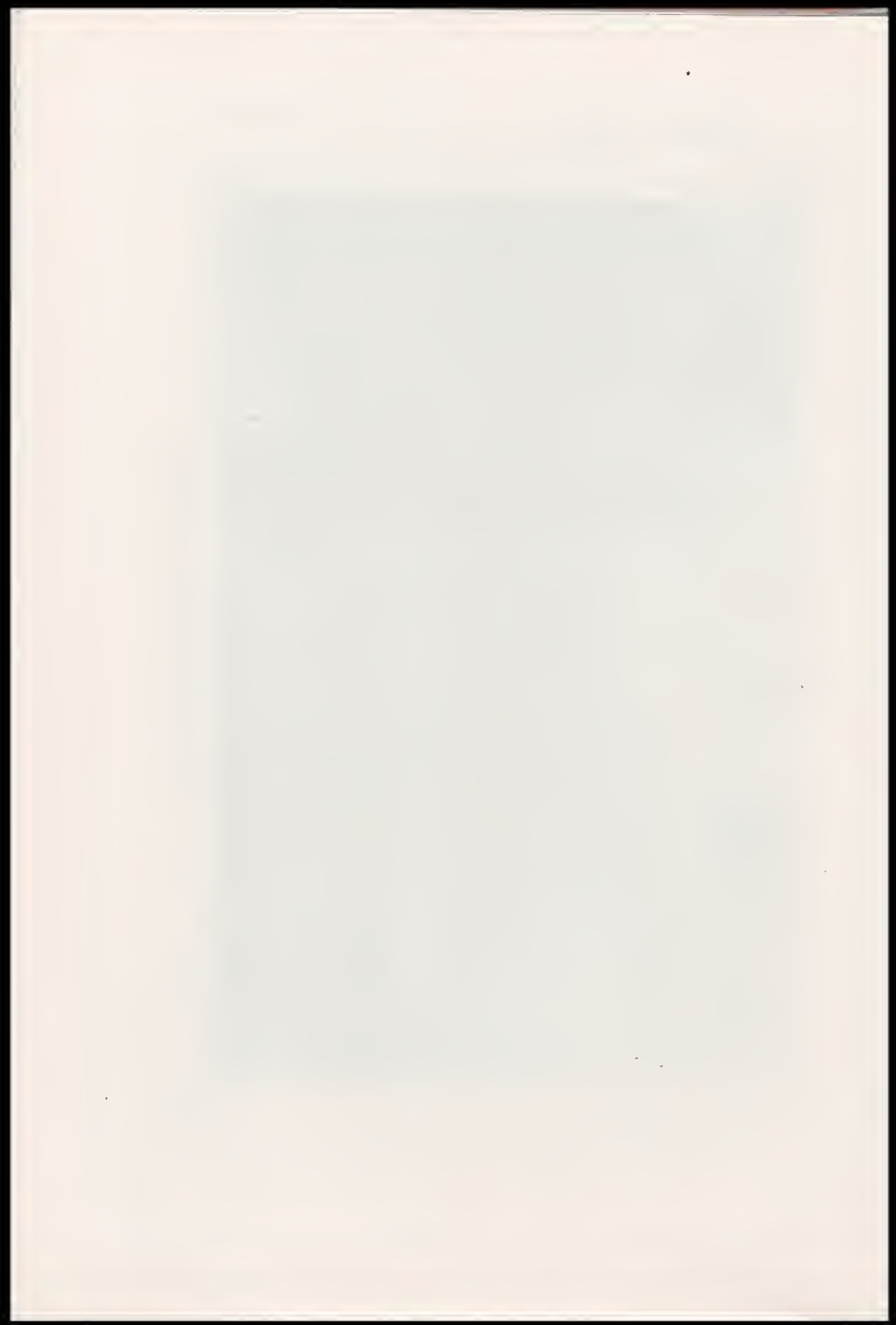

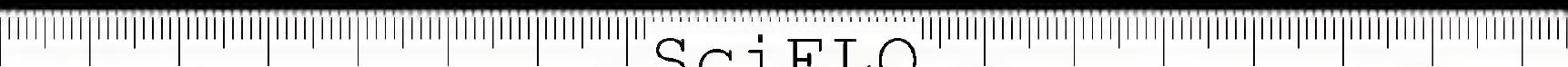

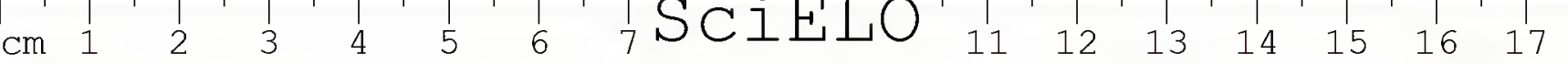


supplementary volume of his "Entomologia Systematica", he went to Paris for a third time.

From 1798 to 1804 he went each spring to Copenhagen, to describe the many new insects which his friends and pupils Sehestedt and Tönder Lund had amassed and which had already formed basis for a great part of his descriptions from the Mantissa onwards.

Niels Tönder Lund (1749-1809) was tutor to the young Count Ove Sehestedt, and for a period of two years, both of them had attended lectures by Fabricius in Kiel and became keen collectors of Danish insects, especially Tönder Lund. The collections also included many tropical insects. Both Sehestedt and Tönder Lund held high posts in the Civil Service, through which they were able to contact officials sent out to the Danish colonies in Guinea, Tranquebar, and the West Indies (e. g. Rohr, Smidt, and Pflug). and from these regions they obtained large collections of insects. Later on, the two friends, Sehestedt and Tönder Lund, combined their collections, and the right of possession was transferred to Tönder Lund (Zimsen, 1964).

After 1800 Fabricius decided to treat every "class" of insects as a whole. This was the origin of the "Systema Eleutheratorum", "Systema Rhyngotorum", "Systema Antliatorum", "Sytena Piezatorum", and "Systema Glossatorum".

Every summer Fabricius went to Paris in order to see the collections, obtaining the specimens collected by Richard, Bose, and Palisot de Beauvois. In the winters he remained in Kiel to fulfill his duties to the University and give lectures on natural history and economics.

His last completed entomological publication was the "Systeina Antliatorum", where he adds many new species to those already described by Linnaeus and himself. The collections made by Banks and Solander in Rio de Janeiro, those obtained by Richard, Palisot de Beauvois, Bosc, Rohr, Smidt, and Pflug in the Guianas and the West Indies, were included by Fabricius in the "Systema Antliatorum".

The great entomologist died on the 3rd of March, 1808 (Hope, 1845; Latreille, 1808; Tuxen, 1959, 1967).

Fabricius' own collection remained in Kiel after his death and belongs to the Zoological Museum of Kiel. In 1950, it was transferred to the Zoological Museum of Copenhagen, where it is now kept as a "Dauerleihen" from the Museum of Kiel. According to Zimsen (1964: 11): "The Diptera collection is a tra- 
gedy. Among the ten existing boxes there is only one in which the insects are reasonably well preserved, the rest has been eaten away by dermestids. There is reason to suppose that the collection was spoiled even at the beginning of the last century, since many authors at the time mention its miserable condition. The Kiel Museum authorities have fortunately had the good idea to keep the name labels even if any insect was missing. They can tell us with certainty that the type does not exist. It may be noted that Sehestedt and Tönder Lund's collection comprises many Fabrician species donated by himself. Among these specimens lectotypes may be chosen if the type itself is lost".

\section{References}

Pabricius, J. C.

1775. Systema entonologiae, sistens insectorum classes, ordines, gencra, speeies adicctis synonymis, locis, descriptionibus, observationibus, 832 pp. Flensburgi et Lipsiae (= Flensburg and Leipzig).

1776. Genera insectorum corumque characteres naturalcs secundum numerum, figuram, situm ct proportionem omnium partium oris adiecta mantissa specierum nuper detectarum, 310 pp. Chilonii (= Kiel).

1781. Speeies insectorum exhibentes eorum differentias specificas, synonyma, auctorum, loca natalia, metamorphosin, 2 : 517 pp. Hamburgi et Kilonii (= Hamburg and Kiel).

1787. Mantissa Insectorum sistens spceies nuper detectas 2 : 382 pp. Hafniae (= Copenhagen).

1794. Entomologia systematica emendata et aucta $4: 472$ pp. Hafniae (= Copenhagen).

1798. Supplementum entomologiae systematicae, 572 pp. Hafniae (= Copenhagen).

1805. Systema antliatorum secundum ordines, genera, species, $373+30$ pp. Brunsvigae (= Brunswick).

Hope, T. W.

1845. The autobiography of John Christian Fabricius, translated from the Danish with additional notes and observations. Trans. Ent. Soc. London 4 (Suppl.) : 1-16.

Latreille, P. A.

1808. Notice biographique sur Jean Chrétien Fabricius, conseiller d’ètat du roi de Dannemarck, professeur d'histoire naturelle et d'économie rurale à Kiell, et membre d’un grand nombre d'académies. Ann. Mus. Hist. Nat. Paris 11 : 393-404. 
Tuxen. S. L.

1959. Der Entomologe I. C. Fabricius und die Typen der von ihm beschriebenen Arten. Zool. Anz. 136 (11-12) : 344-350.

1967. The entomologist, J. C. Fabricius. Ann. Rev. Ent., Palo Alto, Calif. $12: 1-14,1$ pl.

Zimsen, E.

1964. The type material of I. C. Fabricius, 656 pp. Munksgaard, Copenhagen. 


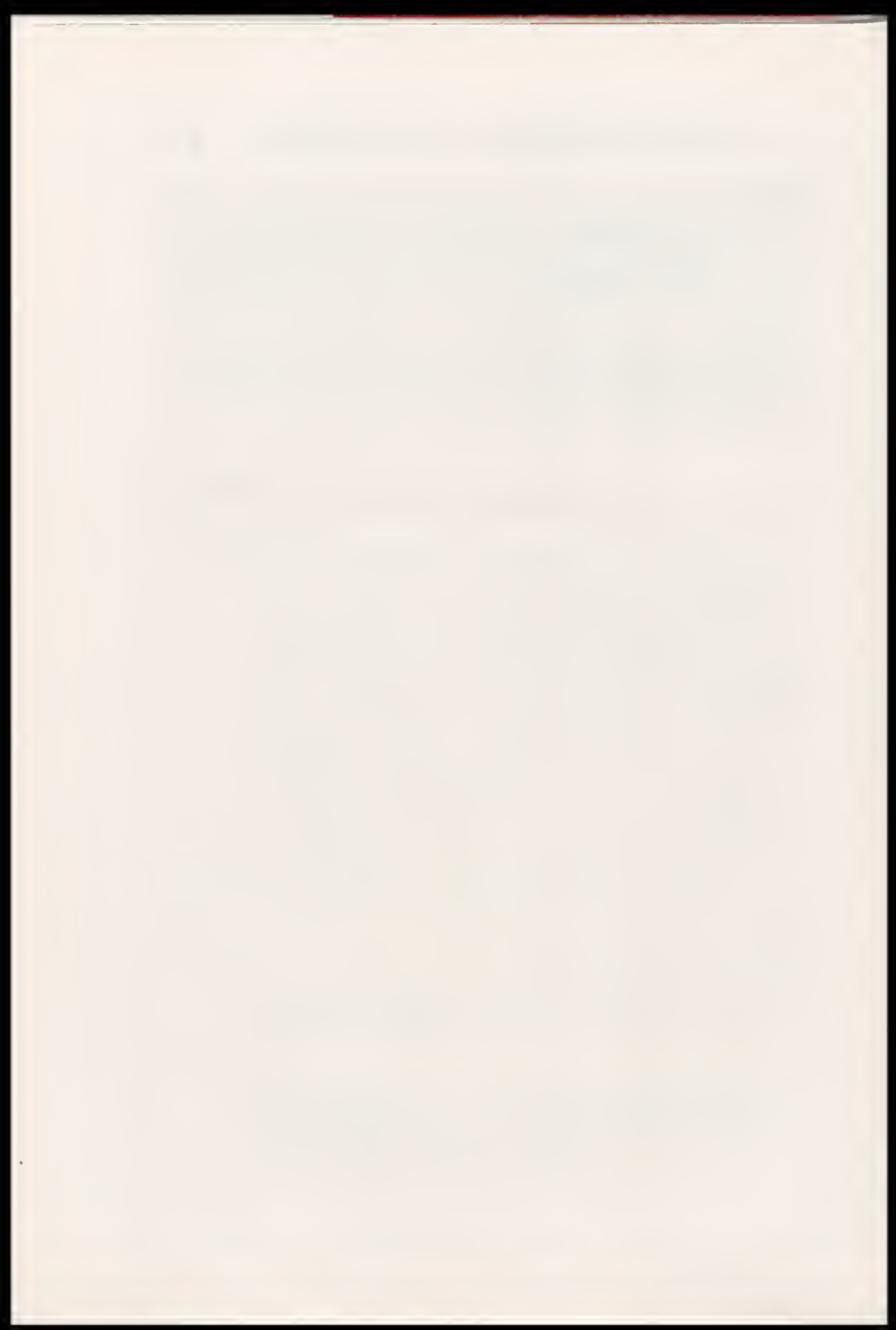

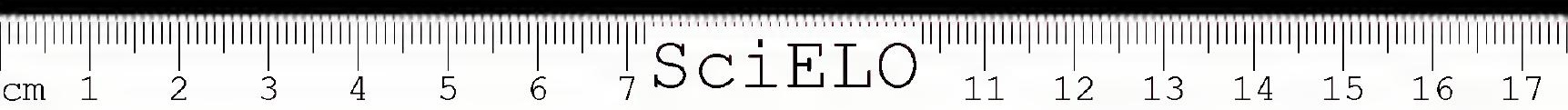


Chapter IV

\section{Travels of Humboldt and Bonpland}

\section{Humboldt and Bonpland}

On 5 June 1799, the frigate "Pizarro" sailed from the Spanish port of La Coruña for Havana, Cuba, with Alexander von Humboldt and Aimé Bonpland aboard, bound for a scientific expedition to South America.

Friedrich Heinrich Alexander, Baron von Humboldt was born on 14 September 1769, in Berlin. After his father's death in January 1779, his education was continued under Joachim Heinrich Campe, and Gottlob J. Christian Kunth. Campe taught Humboldt the natural philosophy of Jean Jacques Rousseau, according to which the study of history and of the classics should be preceded by the study of nature. This influence of Campe, allied with Alexander's natural tendency to collect everything he could lay his hands on, in the gardens of his family's house in Tegel, developed in him the wish to travel to distant countries to collect specimens and to broaden the knowledge of the physical world. This tendency was also greatly strengthened by the reading of books of travels by Banks and Solander, Cook, La Condamine, etc.

In Tegel, in the autumn of 1785, Humboldt knew the bota nist Karl Ludwig Wildenow, who would later study the plants collected by Humboldt and Bonpland in South America and en- 
courage another naturalist, F. Sellow, to go collecting in South America.

In September 1787, Humboldt went to the University of Frankfurt am Oder, and in the spring of 1787 he moved to Göttingen, as a student. There he met Johann Friedrich Blumenbach, who was teaching anatomy and anthropology, and under his influence Humboldt became interested in those sciences, as well as in the physiological effects of electricity. In Göttingen, Alexander was elected fellow of the "Philosophical Society", at whose meetings he could hear the conferences of Christian Gottlob Heine, the establisher of the foundations of archeology.

In 1789, while the French nobility was being decimated by the Revolution, Humboldt studied the geology of the Rhine valley, the subject of his first book, printed in 1790. He travelled in 1790 with the famous explorer and naturalist. George Forster, troughout Belgium. England, and other countries. In July 1790 , both returned by way of Paris, where the Revolution was victorious, to Mainz in Germany.

Upon his return, Humboldt entered the Academy of Mines in Freiburg. The director of the Academy was the geologist Abraham Gottlieb Werner. Some of Humboldt's contemporaries would become famous in the geological sciences, as Leopold von Buch, and Fischer von Waldheim. Humboldt finished his course on 26 February 1792, and for some time worked as director of mines. During the epoch he travelled to several localities in Europe.

After his mother's death in November 1796, he became economically independent, having inherited 95.000 talers, which would give him a monthly interest of 3,476 talers. So, in 1798, he decided to move to Paris, at the time when Napoleon was undertaking his Campaign of Egypt.

Paris was then the intellectual center of Europe. At the Jardin des Plantes (the former Jardin du Roi, saved from the rage of the "sans-culottes" by Lamarck), Humboldt made the acquaintance of Bougainville and saw the collections made by him in South America. He also met Baron Cuvier and Geoffroy Saint-Hilaire. At the Institut de France he knew Lagrange, Laplace, and Berthollet.

In Paris he also met the companion of his future expeditions - Aimé Jacques Goujaud Bonpland. Bonpland was born in La Rochelle, parish of Saint-Barthélemy, on 28 August 1773. He studied in his native town, moving afterwards to Paris with his elder brother, Michel Simon, in order to study me- 
dicine, following a family tradition. With Bichat he learned comparative anatomy. Joining the navy, he was sent to Rochefort. where he took some courses which permitted him to attain the grade of "chirurgien de $3 \mathrm{e}$. classe". Returning to Paris in the beginning of 1795 , he studied in several hospitals, and took courses of natural history with Lamarck, Jussieu, and Desfontaines.

His acquaintance with Humboldt was made at a hotel, where both were staying. Bonpland taught Humboldt anatomy and botany, who reciprocated teaching mineralogy and physics to Bonpland.

On October 1798, they went to Lyon and Marseilles, whence they intended to sail to Egypt, on a scientific expedition. On their arrival at Marseilles, however, they learned that the Moslem tribes of northern Africa had rebelled against the French invasion and the authorities denied passports to Argel.

They proceeded to Spain, by way of the Mediterranean coast, coming to Madrid, where Humbold had the pleasure of meeting an old friend of his family, the Ambassador of Saxony, Baron Forell. At that time, Humboldt and Bonpland had formed the idea of collecting in the Spanish possessions of America, and the idea was transmitted to Forell. The latter told the Minister of Foreign Relations, Marquis Luis Urquijo, of Humboldt's decision to travel, at his own expenses, to Mexico and South America. Through the influence of Forell and Urquijo, Humboldt and Bonpland were introduced to the King of Spain, Charles IV, on 17 March 1799, and the monarch became interested in the project.

The interview resulted in the royal permission for the two naturalists to explore the Spanish colonies. With the passport granted, they visited the museums of Spain, to study what had already been collected in the Americas. Hipolito Ruiz and José Pavon, who had recently returned from their adventurous voyages in Peru and Chile, told them of the marvellous natural productions of those countries, but also of the difficulties they would encounter in their travels (an excellent translation of the careful diary of Ruiz and Pavón's travels is given by Dahlgren, 1940; it seems that Ruiz and Pavón collected some insects, which somehow ended in Baron von Hoffmansegg's collection, as shall be seen in Chapter VII).

Nothing could dissuade Humboldt and Bonpland from their intent, and they left Madrid in May 1799, heading for the port of La Coruna, where the "Pizarro" was waiting for them. 
The travel through Venezuela

After the customary stops at Teneriffe and other points, the ship was approaching the West Indies when an epidemic occurred on board. The captain, fearing for the safety of the crew, if the ship were to continue to Havana, as originally planned, changed route on the night of 15 July 1779, and headed for Cumaná, on the coast of Venezuela - where Loefling had landed 45 years before. Next day the passengers landed. Humboldt and Bonpland, by virtue of the passport granted by Charles IV, found no difficulties and were immediately received by the governor of the Province of Nueva Andalucia (Venezuela). Don Vicente Emparán.

Their first week in Cumaná (NC-20, 10-64a) was employed in the exploration of the city's surroundings, which had recently been shaken by an earthquake, and in the verification of their scientific instruments. On the 20th they went to the village of Manicuare (NC-20, 11-64c), then visited the Peninsula de Araya (NC-20, 11-64c), the valley of Cumanacoa (NC-20, 10-64b), ascended the "Cocollar" (Cocovar, NC-20, 10-64b), and made a visit to the mission of the Chayma Indians (all localities in the present State of Sucre). Afterwards they made an excursion to the mountains of Caripe (NC-20, 10-64b. State of Monagas). the "Cueva del Guácharo" (NC-20, 10-64b), and on 22 September they left for the Cerro de Santa Maria (NC-20, 10-64b), arriving at the missions of Catuaro (NC-20, 10-64b). Thence they returned to the Gulf of Cariaco (NC-20, 11-64d, State of Sucre), but the prevailing fevers prevented them from staying any longer, so they proceeded to Cumaná. In the capital of Nueva Andalucia they remained for one further month, preparing their voyage to the Orinoco and the Rio Negro. On November 4th they had the occasion to experience an earthquake.

On 18 November Humboldt proceeded by sea to La Guaira (NC-19, 11-67d) and Caracas (D.F., NC-19, 11-67d), while Bonpland followed overland. When Bonpland returned to $\mathrm{Ca}$ racas, both naturalists explored several parts of the region, spending there the months of November and December 1799. On 14 December 1799, they had collected along the coasts of Venezuela 1600 plants, of which 500 were to be described as new. The rainy season forced them to remain in Caracas, and during that season they climbed the Silla de Caracas and went to the Lake of Valencia (NC-19, 10-68b, between the present States 


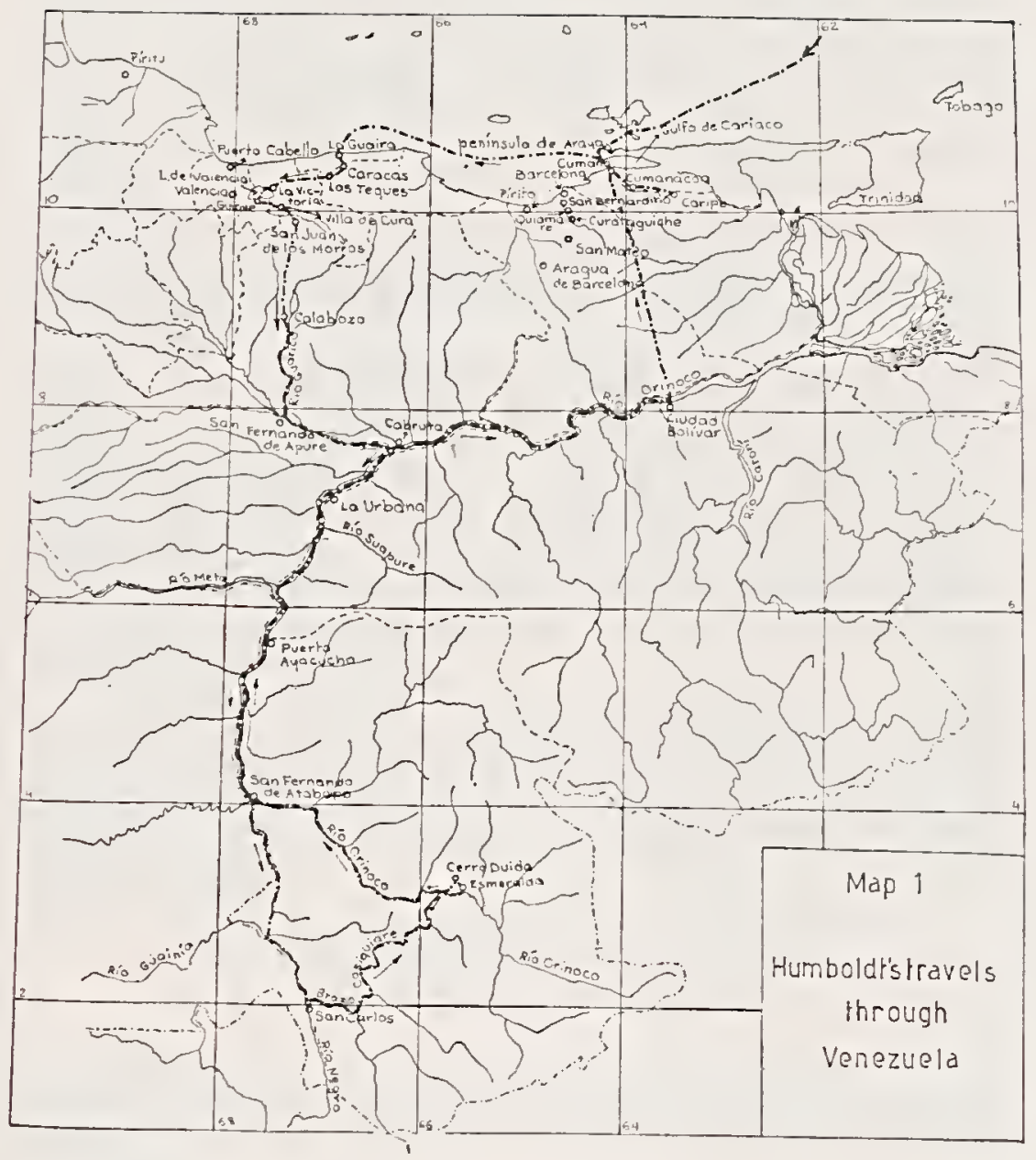




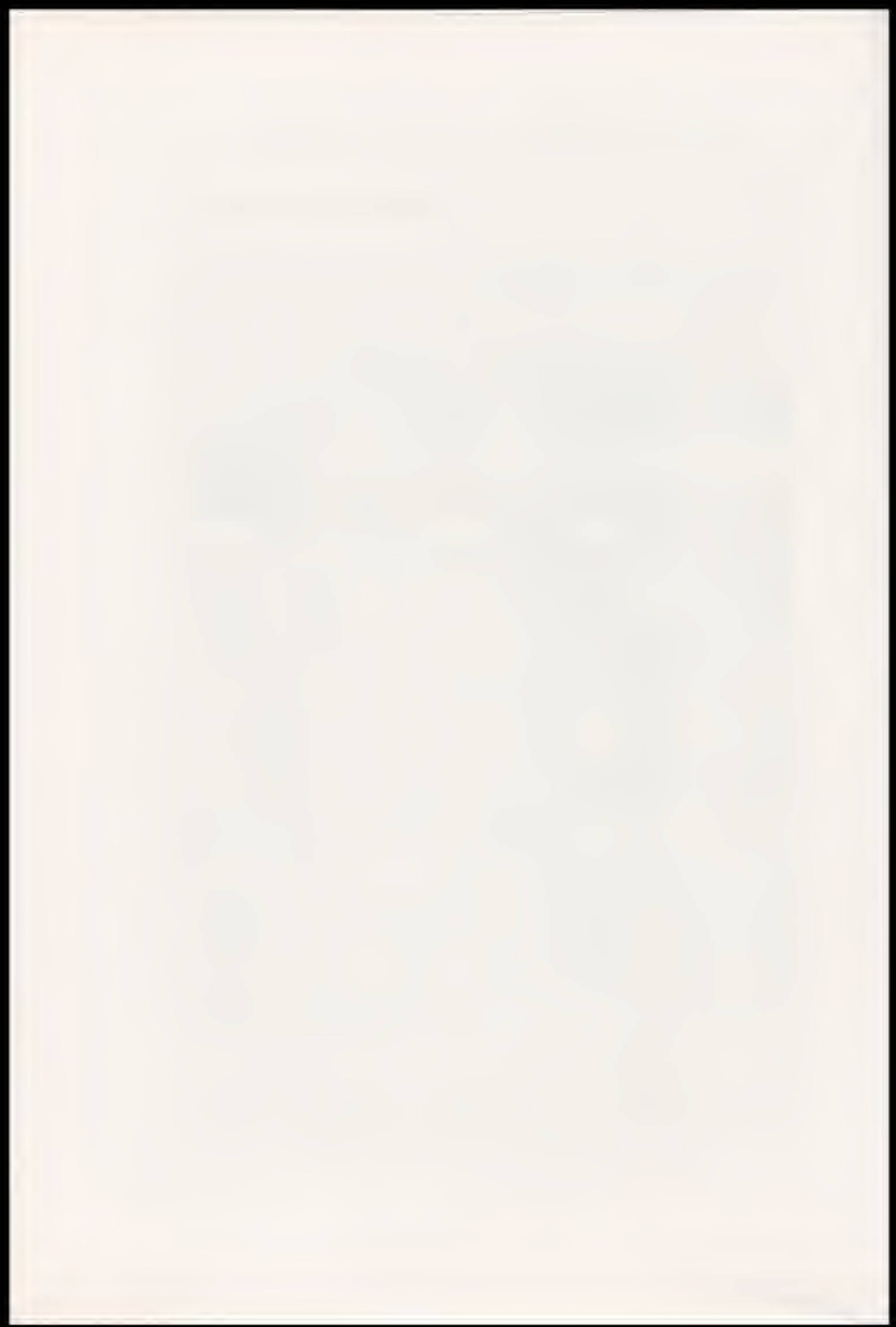

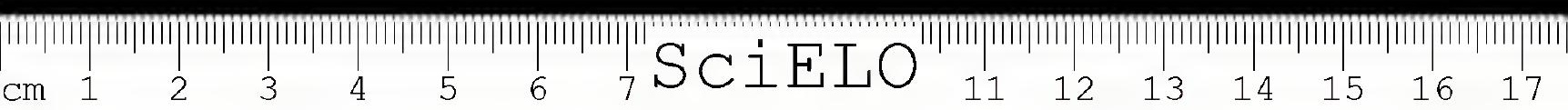


of Aragua and Carabobo), as well as to Puerto Cabello (NC-19, 10-68a, State of Carabobo).

In February 1800, they finally left the coast to travel to the Orinoco. They crossed the mountains of Los Teques (NC-19, 10-67a), La Victoria (NC-19, 10-67a), Lake Valencia (NC-19. 10-68b), Güigüe (NC-19, 10-68b), Parapara (NC-20, 10-67c). and Calabozo (NC-19, 9-67c; midway between Caracas and the Orinoco, where Humboldt discovered the electric eel), they entered the Rio Guárico (NB-19, 8-67c), and arrived at San Fernando de Apure $(\mathrm{NB}-19,8-67 \mathrm{c})$, at the margins of the Rio Apure.

In San Fernando de Apure the missionaries set their pupils to work, and in 8 days, a pirogue 9 meters long was transformed into a sailboat which would transport the scientists to the frontiers of Brazil. Through the Apure, after two weeks of their departure, they arrived at Cabruta (NB-19.8-66c), already in the Orinoco, and then proceeded to the mission of Concepcion de Urbana (now La Urbana, NB-19, 7-67b), and after passing the rapids of the Orinoco, the mouth of the Meta River (NB-19, 6-68b), the Raudal de Maipures (NB-19, 5-68b), where they spent 3 days, Atures, the mouth of the Sipapo River (NB-19. 5-68b), they arrived at the mission of San Fernando de Atabapo. The river trip, from San Fernando de Apure to San Fernando de Atabapo took 33 days.

During the trip on the Orinoco they had been cruelly tormented by 'piuns', 'zancudos', 'mosquitos', 'tempraneros' and other pests (Culicidae, Ceratopogonidae, and Simuliidae). Several pages of Humboldt's narrative are filled with complaints about the painful bites of those flies, which made him remember the verses of Dante,

\section{"Noi siam venuti al luogo, ov'it'ho detto}

Che tu vedrai le genti dolorose".

Proceeding upstream, through the Atabapo, with many sacrifices, they then transported their canoe, overland to the Guainia River (NA-19,3-67c), one of the rivers which forms the Rio Negro.

Humboldt and Bonpland proceeded to the point at which the Orinoco joins the Rio Negro, by the Canal of Casiquiare. They arrived at the city of San Carlos (NA-19, 2-67c), in the frontier between Colombia and Venezuela, near the northern confines of Brazil. During their observations, they crossed to the Brazilian 
side. Humboldt was treated as a spy by the Portuguese authorities. During the night he was arrested, and all his instruments and notes were confiscated.

The Portuguese Crown had given orders to Captain General Francisco Mauricio de Souza Coutinho, Governor of Pará, to prevent Humboldt's travel in Brazilian territory. The "Gazeta da Colonia" (2 July 1800) announced alarmingly:

“... a certain Baron von Humboldt, from Berlin, has been travelling through the interior of America, making astronomic observations in order to rectify certain errors in the existing maps, and collecting plants $(\ldots)$. Under this pretext this stranger may hide plans for the propagation of new ideas and new religious principles among the loyal subjects of this domain. His excellency [the Governor of Pará] should investigate the case (...); otherwise, it would be extremely dangerous to the political intercsts of the Portuguese crown, if this were the case..."

After much discussion, Humboldt was released, and everything was returned to him. On the way back, the scientific party proceeded through the Casiquiare (NA-19, 2-67b; NA-20, 3-66b). passing by Cerro Duida (NA-20,3-66b), entering the Orinoco and descending the latter to San Fernando de Atabapo. Still following the Orinoco, they reached Angostura (presently Ciudad Bolivar). There Bonpland suffered attacks of fever, and his situation was alarming. He was transferred to the house of a doctor, where he was administered infusions of honey and quinine. Humboldt was very afraid of Bonpland's health, and the remembrance, that not far from there, Loefling had died with fevers, did not help. Fortunately Bonpland recovered, and the two naturalists, crossing again the 'llanos' north of the Orinoco, returned to Barcelona, arriving there on 1 September 1880, after having travelled 6,443 miles in the lands of Venezuela (Garcia, 1922; Hagen, 1945; Humboldt, 1861-1862; Terra, 1956).

The trips to Cuba, Nueva Granada (Map 2), and Ecuador (Map 3)

On 24 December 1800, Humboldt and Bonpland left Venezuela for Cuba, where they made several excursions in the interior, after which they returned to Havana. The collections made in Venezuela and Cuba were then divided in 3 portions - one to go to Germany, via England; a second to go to France, via 


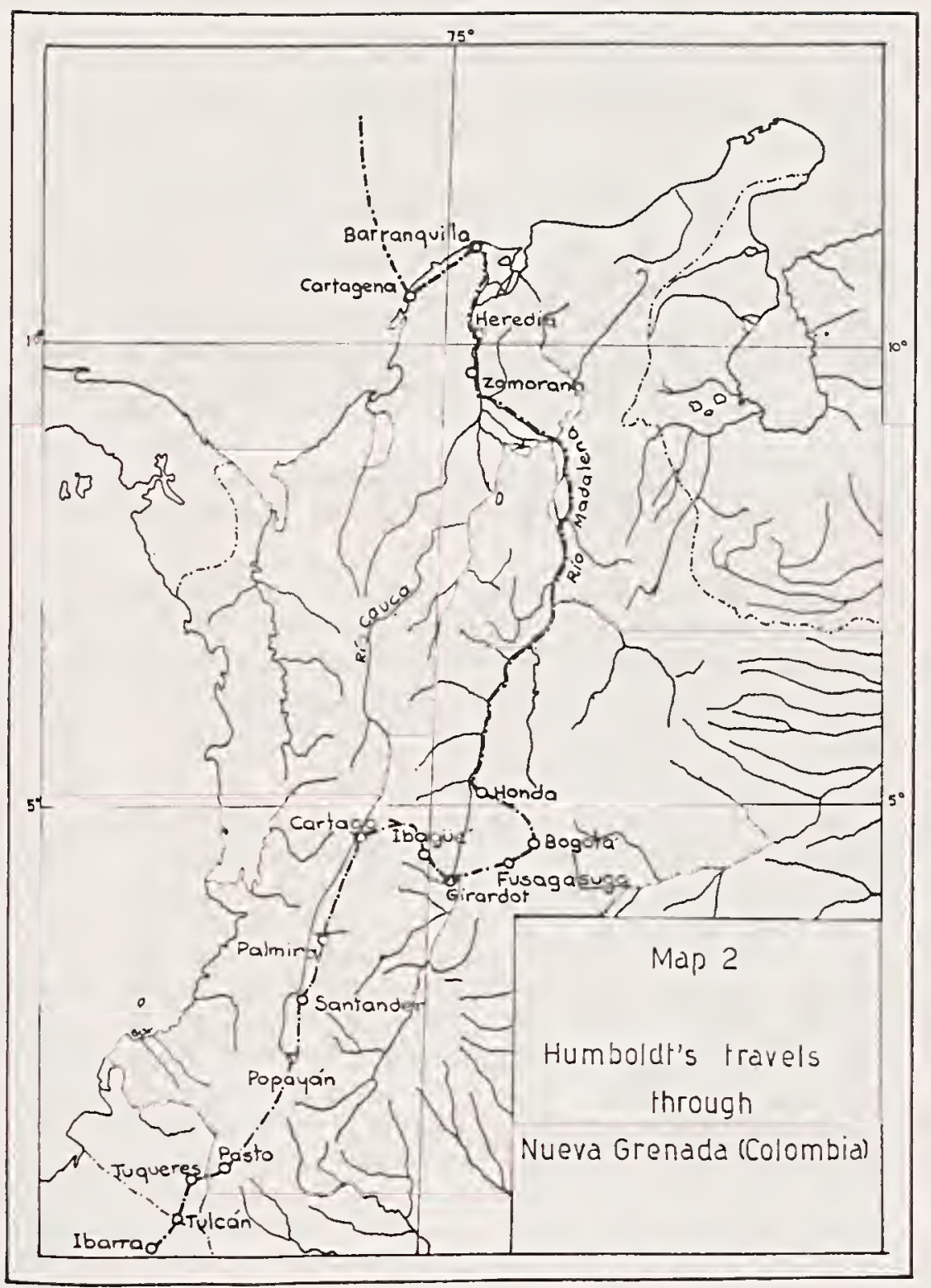

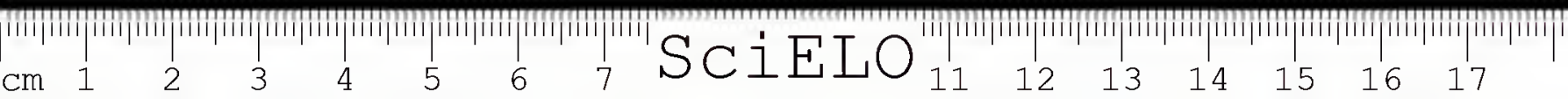




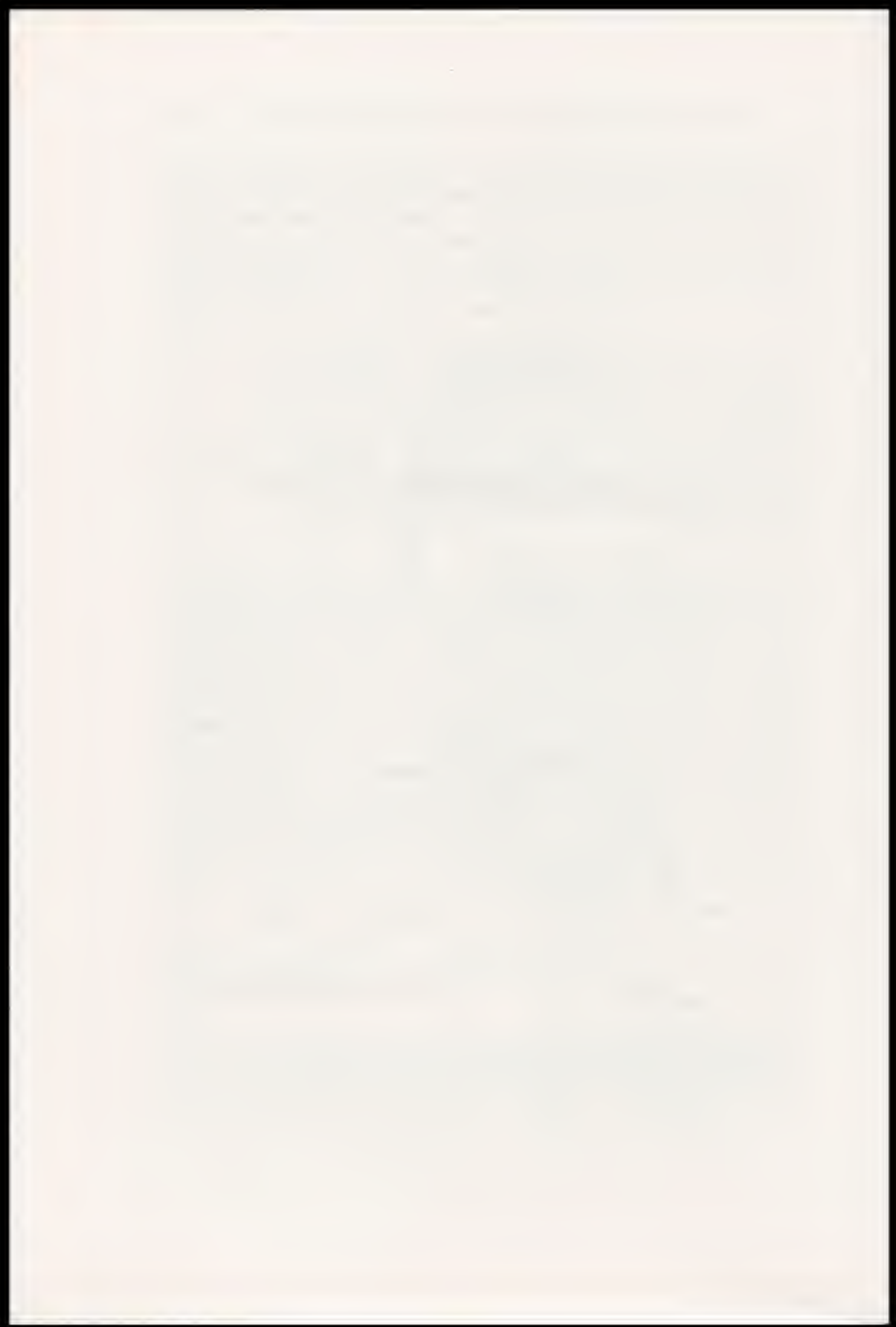

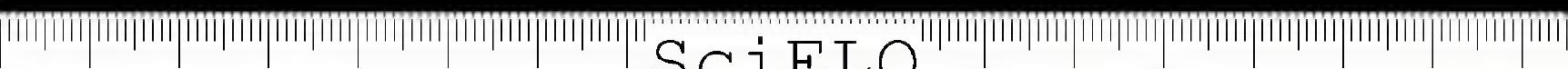

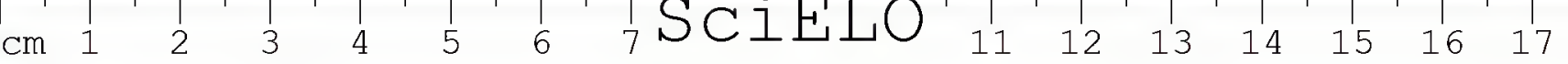


Cádiz; the third to remain in Havana. Father Juán Gonzáles, who had accompanied the two naturalists in the trip through the Lower Orinoco, was to transport the collections destined to Paris. The division of the collections proved an excellent idea, since when Father Gonzáles approached the coast of Africa, the collections and the Father were lost in a shipwreck, after an attack by pirates.

Leaving Havana, Humboldt and Bonpland arrived in Cartagena (NC-18, 10-75a), in the Vicekingdom of Nueva Granada (Colombia). In April they went in a native canoe up the Magdalena River (NA-18, 4-75; NB-18, 5-75b; NC-18, 10-75d). At the end of 55 days of river trip, the canoe landed in the small village of Honda (NB-18, 5-75b). With mules, the naturalists proceeded to Santa Fé de Bogotá (NB-18, 5-74c, 5-75d). There they visited the well-known botanist José Celestino Mutis, who had been sent to Nueva Granada by Charles III of Spain to investigate the flora; his herbarium had 20,000 plants, and he owned a very rich library; an army of artists drew the plants of his collections.

When Humboldt and Bonpland departed from Bogotá, on 8 September 1801, they were accompanied by a disciple of Mutis, José de Caldas. Through the valley of the Magdalena, they passed by Cartago (NB-18,5-76d), and going to the south, by the valley of the Cauca River (NB-18,7-76b), they stopped at the village of Popayan (NA-18, 2-77b), where the month of November was spent. Still proceeding to the south, through the mountains, they spent Christmas in Pasto (NA-18, 1-77a). Shortly after, they left the Vicekingdom of Nueva Granada, entering the "Audiencia de Quito" (Ecuador), passing by Tulcán (NA$-18,1-78 d$ ). Ibarra (NA-17, 0-78a), and arriving in Quito (SA$-17,0-79 \mathrm{~d})$ on 6 February 1802. From Quito they visited the Pichincha (26-28 May 1802), and V. Antisana (March 1802). Leaving Quito on 9 June 1802, they went southward, visiting Iliniza (SA-17, 1-79b) and Cotopaxi (SA-17, 1-79b) before reaching Latacunga $(\mathrm{SA}-17,1-79 \mathrm{~b})$. From Latacunga they went to Riobamba (SA-17, 2-79b), where they stayed for a while, in the meantime making the famous ascension of the Chimborazo (23 June 1802), and visiting Tungurahua (SA-17, 1-79d). From Riobamba, through the Páramo de Asuay, they went to Cuenca $(\mathrm{SA}-17,3-79 \mathrm{~b})$ and afterwards to Loja $(\mathrm{SB}-17,4-79 \mathrm{c})$ and Gonzanamá (SB-17, 4-79c). Traversing the Rio Calvas (SB-17, $4-80 \mathrm{~d})$, south of Gonzanamá, they entered the fabulous lands of the Vicekingdom of Peru. 


\section{The trip through Peru (Map 3)}

After crossing the Calvas River, the naturalists passed through Lucarque, Ayabaca (SB-17, 5-80b; 2 August 1802), Olleros (SB-17, 5-80b), Santa Rosa (SB-17, 5-80b). Yanta, Aranza, Guallaquillo, Hacienda Chulucanas, Guamani (SB-17, 5-80b), Angostura (SB-17, 5-80a), Huancabamba (SB-17, 5-80d), Sonderillo, Mandor, Saulaca, San Felipe (SB-17, 6-70a), Llamoca, Pomahuaca (SB-17, 6-79a), Ingatambo, Pucará (SB-17, 6-80d), Las Huertas, Matará (SB-17, 6-97d), Cabico (SB-17, 6-79b), Chamaya (SB-17, 6-79b), Choros (SB-17, 6-79b), Jaén (SB-17, 6-78b). Tomependa (15 August to 1 September 1802), Jaen-la-Vieja, returning to Cabico, and then following by Querocotillo (SB-17, 6-97c) (5 September 1802), Sigues, Mollebamba (SB-17, 6-79c), Huambos (SB-17, 6-79d). Montán, Santa Cruz (SB-17, 7-79b), Hualgayoc (SB-17, 7-79b), Micuipampa, Yanahuanea, Cajamarca (SB-17, 7-79d), Pultamare (= Baños del Inca), returning to Cajamarca (13-17 September 1802), Magdalena (SB-17, 7-79d), Aroma, Cunturcaga, Huangamarca, Contumazá (SB-17, 7-79d). Chorillos, Los Molinos, San Diego (SB-17. 5-80b), Trujillo (SC-17, 8-79a), Moche, Santa (near the mouth of the Santa River, SC-17, 9-79b). Huambacho (SC-17, 10-78c), Huaura, Huacho, Salinas, Ramadal, Chancay (SC-18, 12-77a), and finally arriving in Lima (SC-18, SD-18, 12-77b). At this point of the voyage they had made 3734 Latin descriptions of plants, of which two thirds were writen by Bonpland. They had travelled 4,000 miles, bringing 35 boxes with collections, the plants only being represented by 60,000 specimens.

In Lima they remained from 23 October to 24 December 1802, preparing their collections. From Callao they sailed aboard the royal frigate "La Castor", on 24 December, going to Guayaquil ( $\mathrm{SA}-17,2-80 \mathrm{~d}$ ), where they remained from 3 January to 15 February 1803. In the meantime they went as far as Babahoyo (SA-17, 2-70a), returning to Guayaquil, and, sailing aboard the frigate Atlante, went to Acapulco, Mexico (Petersen, 1960).

During the trip up the Magdalena River, as well as in the flooded plains of Guayaquil, Humboldt discovered new species of mosquitoes, which were called Culex cyanopensis, C. lineatus, C. Ferox, C. chloropterus and C. maculatus. The diagnoses of the new species are presented in a footnote on page 340 of the first volume of his 'Rélation Historique' (1814). 


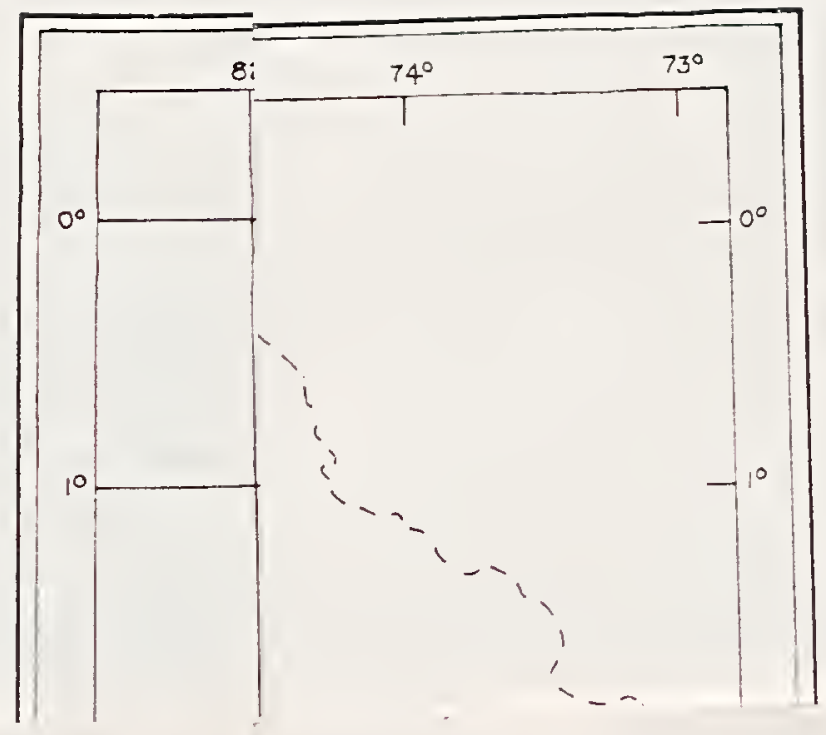

||||||||||||||||||||||||||||||||||||||||||||||||||||||||||||||||||||||||||

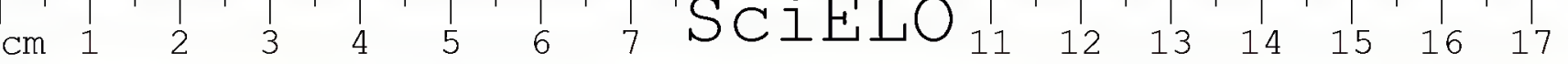




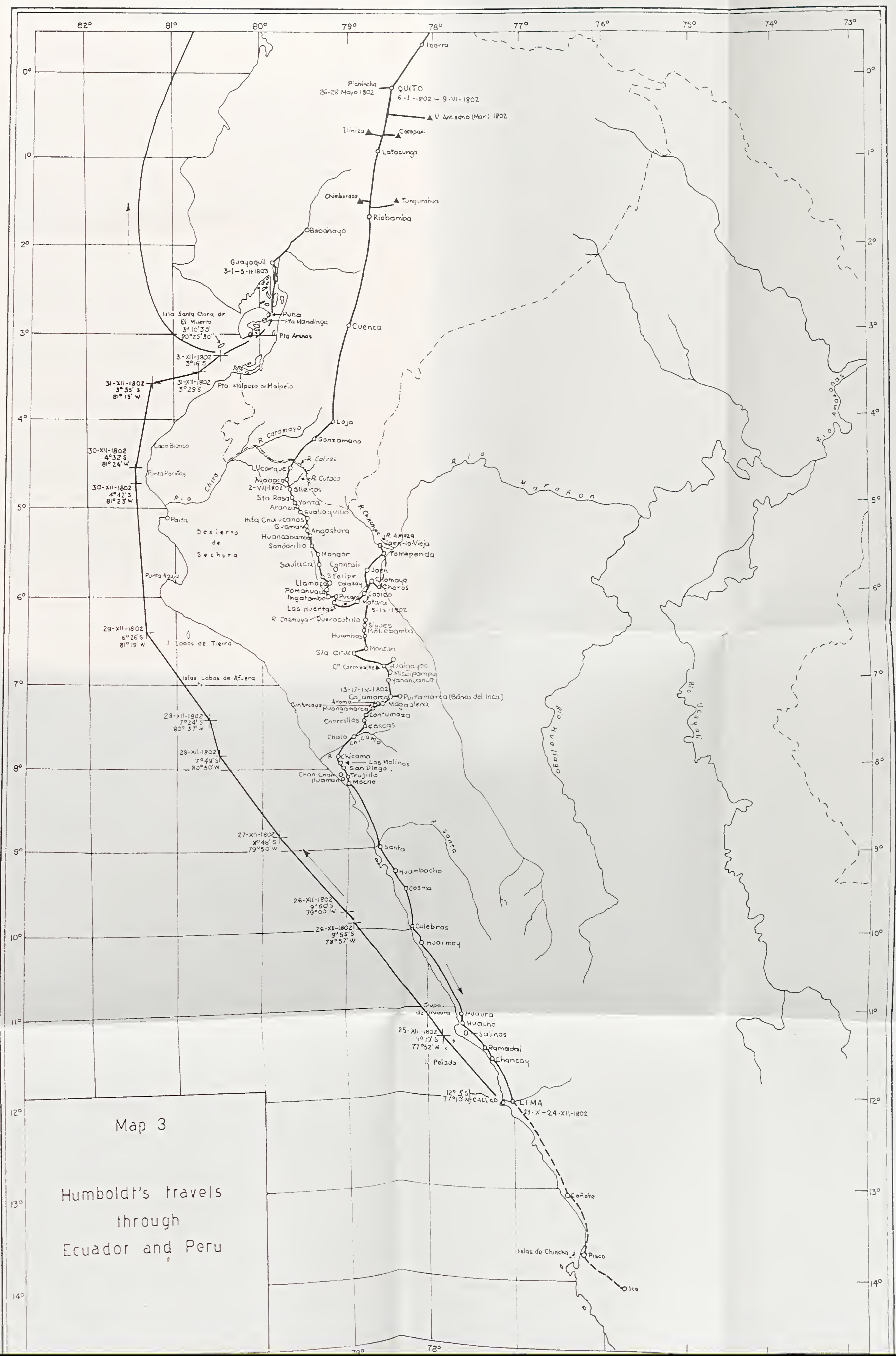




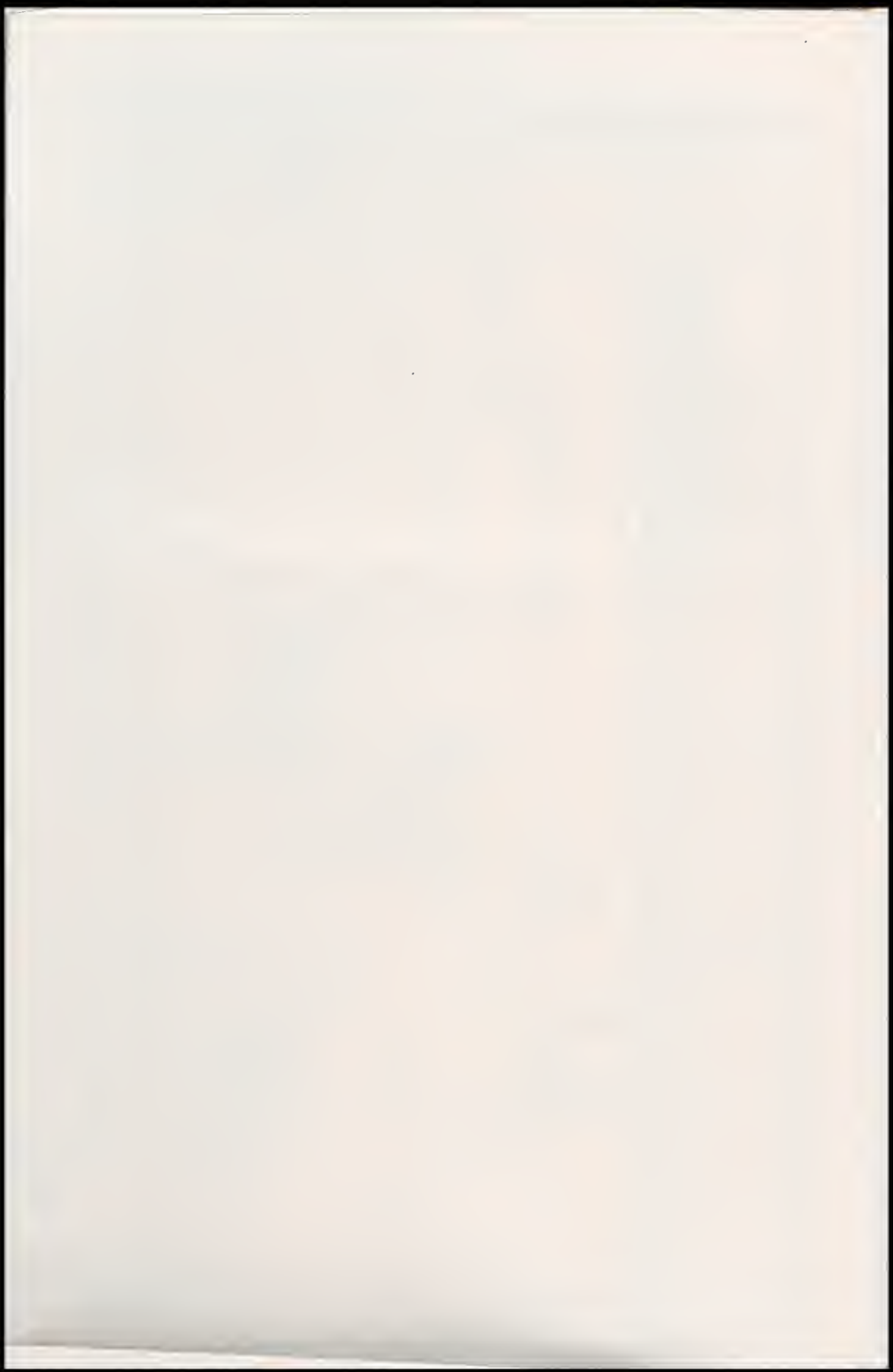




\section{The trip through Mexico (Map 4)}

On 15 February 1803 the naturalists had left the port of Guayaquil, carrying precious collections. On 23 March they arrived in Acapulco (NE-14, 17-100d), in the Vicekingdom of New Spain (Mexico). They began their march to the interior almost immediately, through the present State of Guerrero, passing by Chilpancingo (NE-14, 18-100d), Taxco (NE-14, 19-100d), and Cuernavaca (NE-14, 19-99c). In Mexico City (NE-14, NF-14, 20-100d), they were received by the Viceroy, Count Iturrigaray. After a stay in the Capital, they went, on 1 August 1803, to Guanajuato (NF-13, 21-102d). On 9 September they arrived in Jorullo (NE-14, 19-102d), near Uruapán (NE-14, 19-102b), proceeding thence to Toluca (NE-14, 19-100b), via Morelia (NE-14, $20-101 \mathrm{c}$ ), on the 21 st.

Returning to the city of Mexico, they packed their collections, and on 20 January 1804, went to Veracruz (NE-14, 19. -96a), passing through Puebla (NE-14, 19-98a). They arrived at the former city on 19 February. On 7 March they sailed once more to Cuba, staying shortly in Havana, where they picked up the collections made in the Orinoco and left there since 1801 . Through the consul of the United States, Humboldt received a letter from Thomas Jefferson, inviting him to visit that country. The naturalists sailed for the United States, and after some weeks returned to Europe, arriving there in August 1804.

Humboldt and Bonpland after the travels

The 85,000 talers owned by Humboldt in 1798 were now reduced to 38,500, due to the expenses of the travels in America. In Paris, Humboldt made a contract to pay his editor, Candolle, 180,000 francs for the publication of the big folios relating his observations, and this consumed almost all his fortune. The situation was saved by the King of Prussia, who gave Humboldt a pension to cover his expenses.

Humboldt obtained from Napoleon an annual pension of 3,000 francs for Bonpland, who could then work on the elaboration of the "Plantes Equinoxiales". Bonpland was also nominated director of the botanical gardens of the Malmaison. and private doctor to the Empress Josephine, who was also interested in botany. When Napoleon divorced Josephine, Bonpland's luck chan- 
ged, since he was a "protegé" of the Empress. He was then invited to go to Caracas, in Venezuela, by Simón Bolivar, but could not accept for several reasons. By that time, Bernardino Rivadavia was in Paris, trying to find people who wanted to go to Argentina. Bonpland accepted the offer to go to Buenos Aires.

On 23 November 1816, he embarked on the "Saint-Victor" for La Plata, arriving to Buenos Aires on 18 January 1817. In 1820 he became established in the colony Santa-Ana, on the banks of the Rio Parana. Francia, the dictator of Paraguay, had the idea that the colony belonged to his country, and that Bonpland was an agent of the Argentinian government. On 8 December 1821, 400 Paraguayans invaded the colony, taking Bonpland as prisoner. The botanist remained imprisoned for seven and a half years (7 December 1821 to 12 May 1829). In spite of all the protests. Francia could not be moved from his silly idea of keeping Bonpland prisoner, not even the menaces of Simon Bolivar of invading Paraguay, as can be seen in the following letter (translated from the Spanish by George C. Steyskal):

“To Scrior Doctor Francia, Dictator of Paraguay

Lima. Octobcr 23, 1523

\section{Most Exccllent Sir:}

Sincc the earlicst ycars of my youth I havc had the honor of cultivating the Friendship of Señor Bonpland and Scñor Baron von Humboldt, whose knowledge has donc more good to the Americas than all thcir conquerors.

$I$ am now confrontcd with thc information that my beloved fricnd Señor Bonpland is bcing held in Paraguay for somc reason unknown to me. I suspect that some false informces have been able to calumniatc this worthy scientist, and that the govcrnment over which your crcellency presides has becn misled in regard to this gentleman.

Two circumstances impcl mc to ask your cxccllcncy most carnestly for the freedom of Scrior Bonpland. The first is that $I$ ant the causc of his coming to Amcrica, because it was I who invited him to move to Colombia, and having alrcady decided on his journcy. the circumstances of war forced him to turn to Buenos Aires: the sccond is that this savant can brighten my country with the light of his wisdom, if you will only have the goodncss to allow him to comc to Colombia, whose government I preside oucr by the will of the people.

Doubticss your exccllency knows ncither my namc nor my scrvices to the American cause; but if $I$ werc to use all my pouer to secure the frccdom of Scrior Bonpland, I would still direct this rcqucst to your cxccllcncy. May your cxccllency deign to hear the clamor of 4 million Americans frccd by the army I command, all of whom together with me implore your cxcelleney's cicmency out of respect for humanity, wisdom, and justicc, out of respect for Serior Bonpland. 


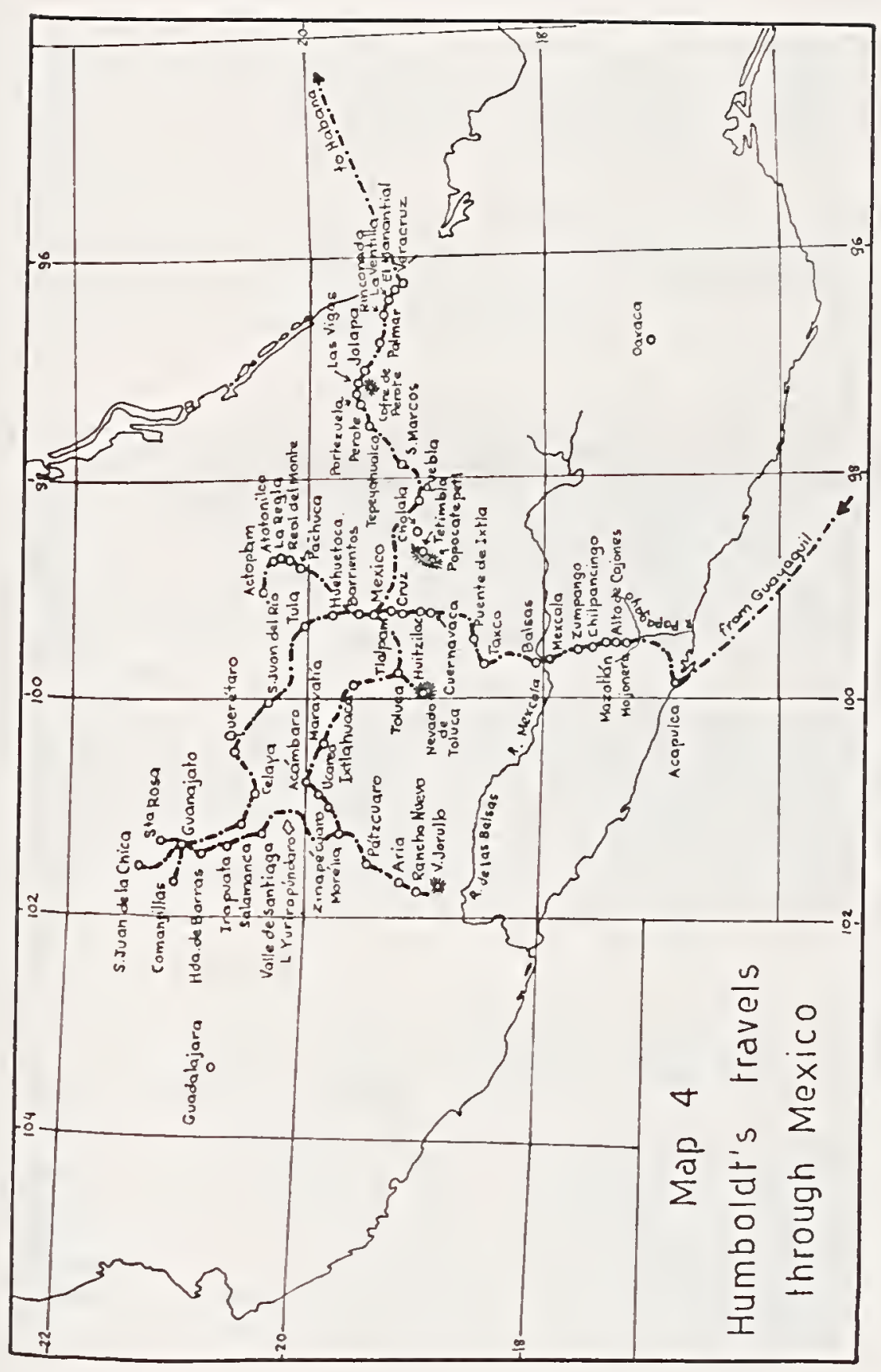

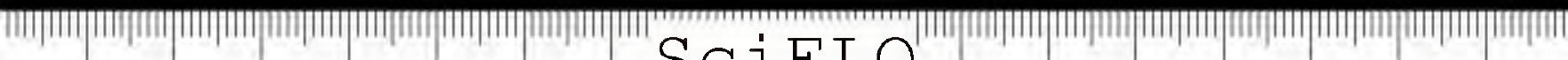

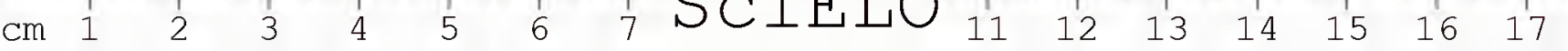




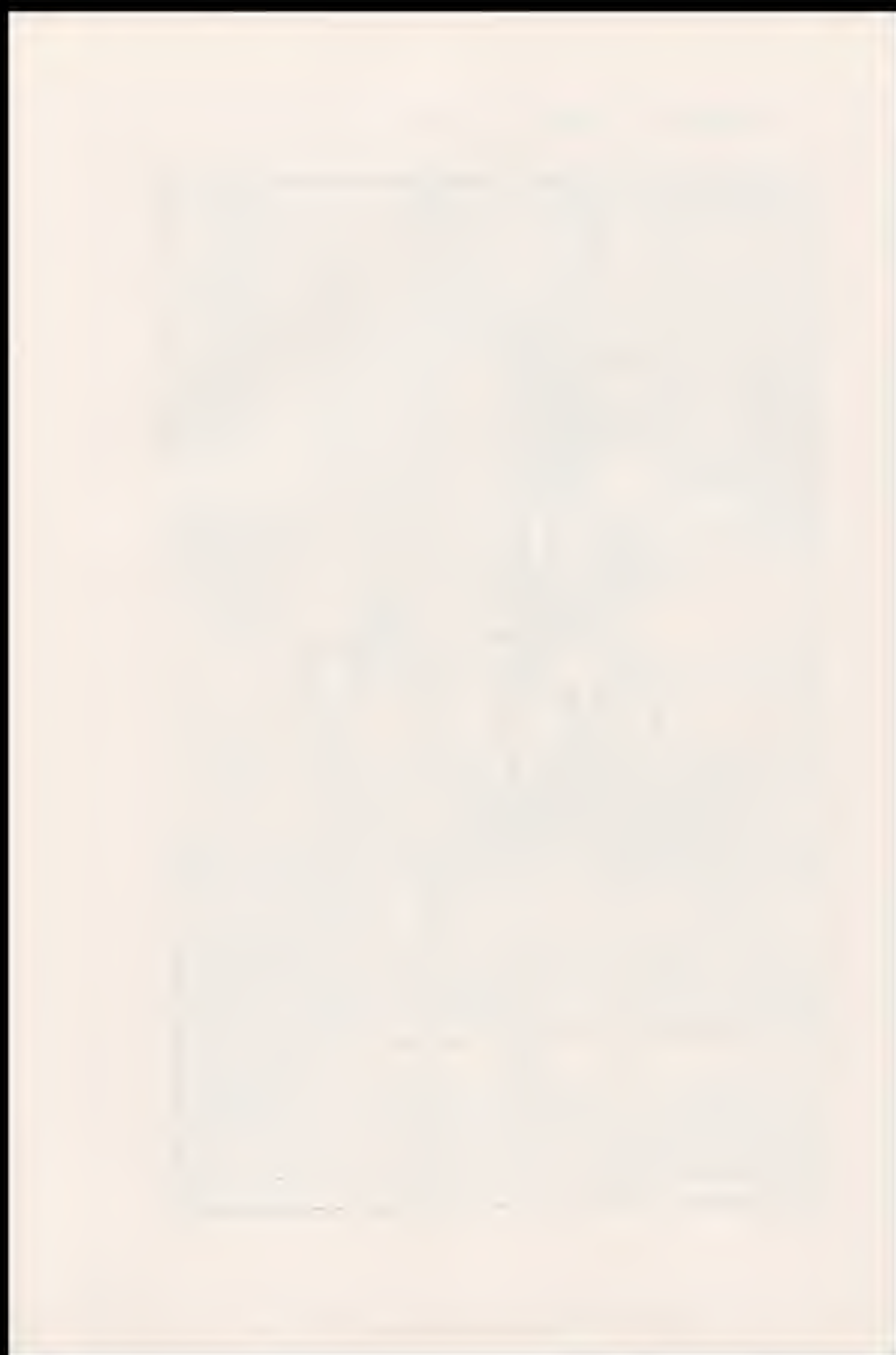

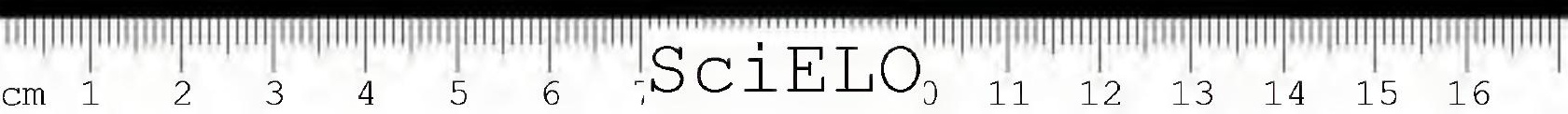


Señor Bonpland can swear to your excellency before he leaves the territory you command, that he will leave the provinces of the Rio de la Plata in order not to be able in any manner at all to cause any prejudice toward the province of Paraguay, and that I meanwhile will be awaiting him with the anxiety of a friend and the respect of a disciple who would be capable of marching on Paraguay just to libcrate the greatest of men and the most famous of travelers.

Most excellent Sir, I hope that your excellency will not leavc my ardent request without effect and $I$ also hope that your excellency may count mc among your most faithful and thankful friends as soon as the blameless one whom I love is no longer a victim of injustice.

I have the honor to be your excellency's attentive and obedient servant.

\section{Bolivar".}

Finally, after several interrogations, Bonpland was set free on 2 February 1830. Bonpland made then several trips in the region, and finally returned to Buenos Aires, in April 1832. From then on, he made several trips through Argentina (Corrientes). Uruguay, and the western part of Rio Grande do Sul, in Brazil, always collecting plants. He died on 11 March 1858, in Restauración. During his lifetime he collected 10,000 species of American plants.

While all this occurred. Humboldt printed his monumental "Voyage au régions équinoxiales du nouveau continent, fait en $1799,1800,1801,1802,1803$ et 1804", and several other important works. He also made a trip to Russia, and, surrounded by great fame and the respect of the learned world, he died in 1859 . at the age of 90 years (Hagen, 1945; Hamy, 1906; Terra, 1956).

\section{Pierre André Latreille}

The chapter on insects for Humboldt's 'Recueil d'observations de zoologie et d'anatomie comparé was entrusted to the leading entomologist of France, Latreille.

Pierre André Latreille was born on 29 November 1762, in Brive, a small village in the Province of Limousin, France, and died in Paris on 6 February 1833, in consequence of a "vesical affection". He was the natural son of General Jean Joseph Sahuguet d'Amarzit. Baron d'Espagnac, and a noble woman, whose name is not known. His mother, before his birth, took refuge in the village of Brive, being attended by a doctor named Laroche. The child was taken to a nearby church, where some peasants 
took care of him. He was baptized with the simple name of Pierre-André, since his father was unknown. Only in 1813, by decision of the Tribunal of Brive, "Latreille" was officially added to the name of the great entomologist.

His first studies were made in his native town, and $D_{r}$. Laroche and a certain Malepeyre developed in him the taste for natural history, lending him some books on the subject. In 1778 . he left Brive to live with his father, who had recognized him, and entered the college of Cardinal Lemoine. On his father's death, in 1783, his studies were financed by the family d'Espagnac, and Latreille was transferred to the Seminar of Limoges, where he was ordained priest in 1786 .

During the French Revolution, he took refuge among his friends in his native Brive. However, as he had not presented himself to swear the new Constitution, they could not help him. and Latreille was arrested and condemned, together with 73 other priests, to be deported to Cayenne.

While he waited in the prisons of Bordeaux to be deported he saw a tiny beetle coming out of the walls of his cell. While he was examining it, the doctor of the prison. marvelling to see such an interest in a prisoner, asked him whether it was some rare insect. Receiving a positive answer, the doctor said:

- In that case, I would be glad to have it. I know a person who collects insects. who would appreciate having the specimen you have collected.

- Here you have it, answered Latreille, but I want to be informed of the name of this animal.

The doctor's friend was Bory de Saint Vincent, a great student of natural history, who would later be a member of the French House of Representatives, and one of the founders of the Société Entomologigue de France. Bory de Saint-Vincent was not able to identify the beetle, and it was returned to Latreille. Informed by the doctor, Latreille asked for Saint-Vincent's help. saying: "I am Latreille, condemned to die in Guiana, before finishing my studies of the genera of insects created by $\mathrm{Fa}$ bricius".

Bory de Saint-Vincent used his influence among the representatives of the Revolution, and obtained an order of conditional liberty for Latreille, and went immediately to the prison. Arriving there, however, he had the disappointment of finding out that the prisoners had already sailed, and the ship was descending the Garone River. A friend of Bory de Saint-Vincent at once 
took a boat, and both reached the ship. Once the order was exhibited, Latreille was released. But only in 1794 would he be definitely set free.

In 1796 Latreille published his 'Précis des caractères génériques des Insectes, disposés dans un ordre naturel'. In 1798 he received a contract at the Paris Museum to work there for three months, receiving the miserable sum of 4.20 francs a day; through the influence of his protector, Lamarck, the contract was always renewed. In 1794, Latreille had been appointed "aide-naturaliste", and in 1805 was confirmed in that position. During the years 1802 to 1805 he printed the 14 volumes of his 'Histoire Naturelle, générale et particulière, des crustacés et des insectes'.

He remained as "aide-naturaliste" until 1820 , publishing in the meantime his 'Genera crustaceorum et insectorum' (18061809), the 'Considérations générales sur l'ordre naturel des animaux composant les classes des Crustacés, des Arachnides et des Insectes' (1810), the chapter on insects in Cuvier's 'Règne Animal', and the 'Mémoires pour servir à l'histoire des Insectes' (1819).

In 1820, he replaced old Lamarck, then almost entirely blind. With the death of the great zoologist in 1829, the chair of "zoology of insects, worms, and microscopic animals" became vacant, and at the same time it was divided to create a separate chair of entomology, the first created in the world. On 10 March 1830 , Latreille was designated to occupy it. He remained in that post until his death in 1833 (Nussac, 1907; Carrera, 1958).

Latreille described only one species of Neotropical Diptera in his "Insectes de l'Amérique Équinoxiale" (1811) - Tabanus trilineatus. The remaining flies collected by Humboldt and Bonpland in the Americas would be described by Wiedemann, Robineau-Desvoidy, and Macquart.

\section{References}

Carrera, $\mathrm{M}$.

1958. Pierre-André Latreille. Bol. Soc. Brasil. Ent., São Paulo 1 (9) : 7-18, illus.

Garcia, R.

1922. Historia das expediçōes scientificas, pp. 856-910, in Instituto Historico, Geographico e Ethnographico Brasileiro, Diccionario Historico, Geographico e Ethnographico do Brasil 1 : 1688 pp. Rio de Janeiro.

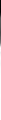


Hagen, W. von

1945. South America called them, xn $+311+\mathrm{xx}$ pp., illus. Alfred A. Knopf. N. York.

Hamy, E. T.

1906. Aimé Bonpland, médécin et naturaliste, explorateur de l’Amérique du Sud: sa vie, son oeuvre, sa correspondence, avee un choix de pièces relatives à sa biographie, un portrait et une carte, Xcvi +300 pp., portrait, 1 map. Librairie Orientale ES Américaine E. Guilmoto, Éditeur. Paris.

Humboldt, A. von

1814. Relafion historique $1: 352 \mathrm{pp}$. [Atlas géographique et physique (1814-1819], in A. von Humboldt \& A. Bonpland, 1805-1837 : Voyage aux régions équinoxiales du nouveau continent, fait en 1799, 1800,1801, 1802, 1803 et 1804, 24 vols. Paris.

1861-1862. Reise in die aequinoctial-Gegenden des neuen Continents 1 (1861) : xi1 + 260 pp.: 2 (1861): 300 pp.: 3 (1862) : 242 pp.; 4 (1862) : 293 pp.; 5 (1862) : 267 pp.; 6 (1862) : 396 pp. J. G. Gotta'scher Verlag, Stuttgart.

Latreille, P. A.

1811. Insectes de l'Amérique Équinoxiale, recueillis pendant le voyage de MM. de Humboldt et Bonpland, pp. 127-252, in A. von Humboldt $\mathcal{E}$ A. Bonpland. Voyage aux régions équinoxiales du nouveau continent. Recueil d"observations de zoologie et d"anatomie comparé, vol. 1.

Nussac, L. de

1907. Les débuts d'un savant naturaliste, le prince de l'entomologie, Pierte-André Latreille, à Brive de 1762-1795, vi + 264 pp., illus. G. Steinheil Editeur. Paris.

Petersen, G.

1960. Sobre la ruta de viaje de Alexander von Humboldt y sus observaciones geológicas y geofisicas en el Peru. Facultad de Letras, Universidad de San Marcos, Publ. Inst. Geogr. (Serie I, Monografias y Ensayos Geográficos) 4 : 101-124, 1 map.

Terra, H. de

1956. Humboldt. su vida $y$ su época. 1769-1859, 313 pp., illus. Biografias Gandesa, México, D.F. 
Chapter V

Collectors in Brazil (1801-1835)

Hoffmannsegg's collectors: Sieber, Gomes, Feijô

As we have seen, Humboldt had been able to count on the special favor of the Spanish Crown for his travels. However, he was strictly forbidden to enter Brazil by the Portuguese authorities. This was in accord with the regulations made by the Portuguese Government that no foreigners could enter the Brazilian territory. A small kingdom like Portugal did not feel that it could afford, in an epoch of fierce competition with other European powers over colonies in South America, that strangers could travel through an enormous colony like Brazil, disseminating ideas of independence. No naturalist, therefore, was allowed to enter the colony to study the land and its products, or to collect natural history specimens, even if that was his sole purpose.

However, by the end of the 18 th century, Johann Centurius, Count von Hoffmannsegg, who had been travelling in Portugal to collect and study plants, was able not only to obtain the esteem and friendship of the inhabitants, but even that of the King himself. He was much interested in increasing his collections of insects, and had written a booklet with instructions to collectors who might be interested in sending him insects of the Portuguese possessions in the four continents (1798). 
Hoffmannsegg's influence was so great that he obtained from the King of Portugal a permission, absolutely unique in that epoch. to send to Brazil his servant and preparator, Friedrich WiLHELM Sieber.

Leaving Lisbon in the first year of the new century (1801). Sieber went to the Province of Pará. where he remained 12 years in constant activity, not only in the vicinity of Belém (SA-22. 49-1d), but also travelling to different parts of the Provinces of Pará and Rio Negro (the latter now the State of Amazonas). He collected along the Rio Amazonas, near the mouth of the Rio Tocantins (SA-22,55-2a). Cametá (SA-22, 50-2d). Monte Alegre (SA-21, 54-2a), Santarém (SA-22, 54-3a), Óbidos (SA-21, $55-$ $-2 a)$, and in the vicinity of the Rio Negro (SA-19,67-0d). He gathered many specimens, which were sent to the Count, especially in 1806 and 1809 (Stresemann, 1950, 1951; Urban, 1908).

The collections of Count von Hoffmannsegg were also enriched by the efforts of two other collectors - Gomes and Feijo.

Francisco Agostinho Gomes was born in São Salvador, Bahia, on 4 July 1769. In accordance with the wishes of his parents, he began to study for an ecclesiastical career, but upon their death, owner of a reasonable fortune, he abandoned those studies for natural history, political economy, and literature. He collaborated in the foundation of the public library of the Province of Bahia, making the gift of his own, at the time the second in the Province. While studying in the University of Coimbra, Portugal, he met Count von Hoffmannsegg, to whom, after his return to Brazil, he sent several insects from Bahia. Elected deputy in Lisbon, Gomes refused to swear the Portuguese constitution, since he was one of those who wanted the independence of Brazil, and had to leave Portugal, going to England, and thence to Brazil, where he spent one year in Pernambuco. Also from Pernambuco he sent some insects to the Count. Gomes was afterwards elected deputy to the first Brazilian Legislation (Assembléia Constituinte, 3 May 1823), and senator in 1826. He was a correspondent member of the Edinburgh Natural History Society, to which he sent several collections from his own museum. He had not only a private cabinet of natural history, but also a laboratory of physics and chemistry. He died on 19 February 1842 (Blake, 1893: Stresemann, 1950, 1951).

JoÃo DA SILva Feıjó was born in Rio de Janeiro in 1760 and died in the Province of Ceará on 9 March 1824. He studied mathematics in the University of Coimbra and served in the corps of engineers, attaining the post of colonel, as well as secretary of the government in the island of St. Jago, in Cape Verde, in the 
last years of the 18th century. Returning to Brazil, he worked for many years in the Province of Ceará, and was named teacher in the Military Academy in Rio de Janeiro. He was a distinguished naturalist, being a member of the Portuguese Royal Academy of Sciences, in Lisbon. He published a book on the Province of Ceará (1810), and an article on the same subject (1814). His other writings were published in other books (1874), or left unpublished, in the National Library of Rio de Janeiro (1800, 1809, 1810).

The collections of Hoffmannsegg, consisting of materials gathered in the Amazons by Sieber, in Pernambuco and Bahia by Gomes, and in Ceará by Feijó, were afterwards presented by the Count to the Museum of Berlin, and served for the first dipterelogical publications of Wiedemann. A certain BELTRÃo, who seems to have been a judge in Rio de Janeiro, and about whom nothing else is known, also seems to have sent material to the Count. A butterfly (Calligo beltrao) was named after him.

\section{The Russian expeditions}

Several events changed the politics of isolation imposed by Portugal on her Brazilian colony. During his war with England. Napoleon demanded that all European nations close their ports to British merchant vessels. Portugal, who had been a traditional ally of England, refused to obey those orders. In retaliation, Napoleon sentenced the small European kingdom, dividing her territory between the Queen of Etruria and the King of Spain, Charles IV. On 19 November 1807, the troops of General Junot invaded Portugal.

The small country could not resist the Napoleonic troops, and the royal family decided to transfer the government to Brazil, leaving on a fleet 27 November 1807, accompanied by the nobility and protected by British warships. During the voyage the ships were separated by a storm, one part landing at Salvador, Bahia, and the other at Rio de Janeiro. The Regent Prince, Dom João VI, arrived in Salvador on 23 January 1808, sailing immediately to Rio de Janeiro, where he landed on 7 March.

Brazil was elevated to the status of United Kingdom, with Portugal and Algarves, with the capital in Rio de Janeiro. One of Dom Joāo's first acts was to open ports of Brazil to the nations of the world, and to permit entrance of foreigners into the country. and travels into the interior. This caused a tremendous affluence 
of naturalists desirous of studying the magnificent nature of the country.

One of the first naturalists to arrive was Baron GEorG Heinrich von LangsdorfF, in 1813, as General Consul of Russia.

Langsdorff was born on 18 April 1774, in Wöllstein, Grand Duchy of Hesse (Germany). He graduated in medicine and natural history from the University of Göttingen. In 1797, at the age of 23 years, he defended a thesis on obstetrics, published under the title "Commentatione medicinae obstetriciae sistens phantasmarum sive machinarum ad artis obstetricia facientium vulgo Fasmae dictorum brevem historiam". Once he had obtained his medical degree, he departed in the same year to Portugal. in the train of Prince Christian von Waldeck, the "generalissimo" of the Portuguese Army. After the death of the Prince he remained in Lisbon as a private doctor, introduced there the practice of vaccination, and learned the language, which would be so useful in his future travels.

In 1801 he engaged himself as surgeon of the British troops, in war against Spain. After the Peace of Amiens he returned to his homeland (1802). On 29 January 1803, he was made corresponding member of the Russian Academy of Sciences.

His first voyage to Brazil was made from 20 December 1803 to 2 February 1804, as a naturalist in the Russian expedition aboard the ships 'Neva' and 'Nadezhda', destined to the exploration of the Americas. This expedition, commanded by Captain, afterwards Admiral, Adam Krusenstern, landed on the Island of Santa Catarina (in the city of Destêrro, presently Florianópolis. SG-22, 48-28a), on its way to Cape Horn. While the ship underwent repairs Langsdorff used his time profitably making frequent excursions in the island and the nearby continent. In those excursions he was accompanied by Manoel Cardoso Caldeira, also a naturalist. There Langsdorff obtained good collections, both zoological and botanical (Krusenstern, 1818). The relation of the voyage was printed by Langsdorff in 1812 .

On 1 April 1812, he was made "academic extraordinary" in zoology, and on 17 June, in botany. In that same year, probably according to his own wishes, he was appointed Consul General of Russia in Rio de Janeiro, where he arrived on 5 April 1813. after a voyage of 67 days.

During his stay in Rio de Janeiro as Consul, from 1813 to 1820, he shared his time between his official duties as consul and agricultural pursuits on a farm, named 'Mandioca' (cassava). which he had bought in the present State of Rio de Janeiro, near 


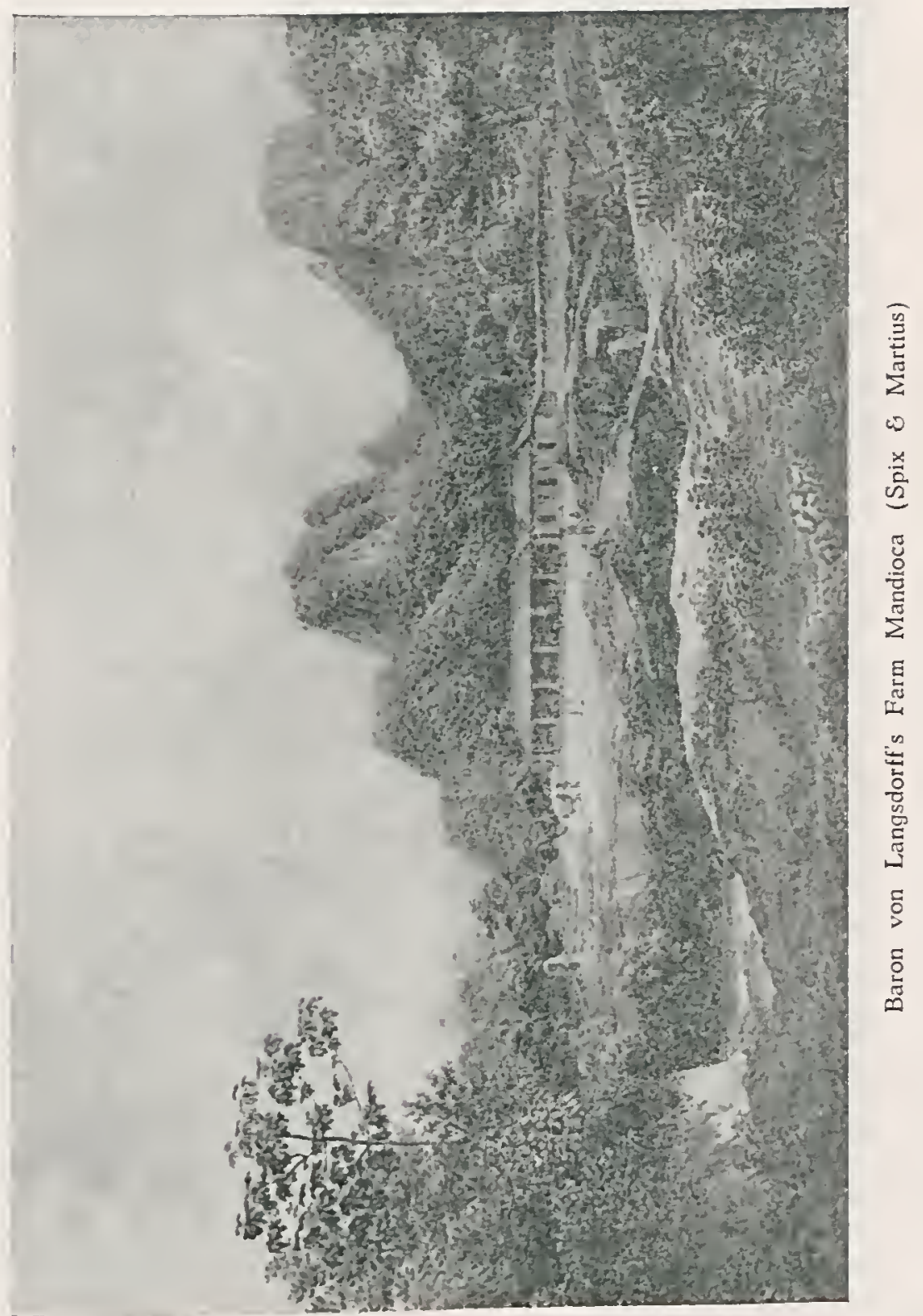

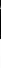

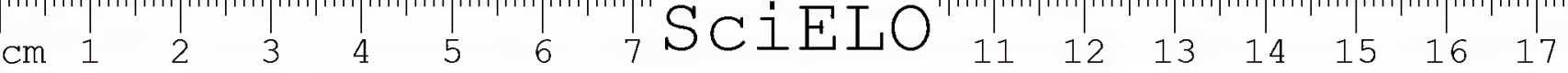




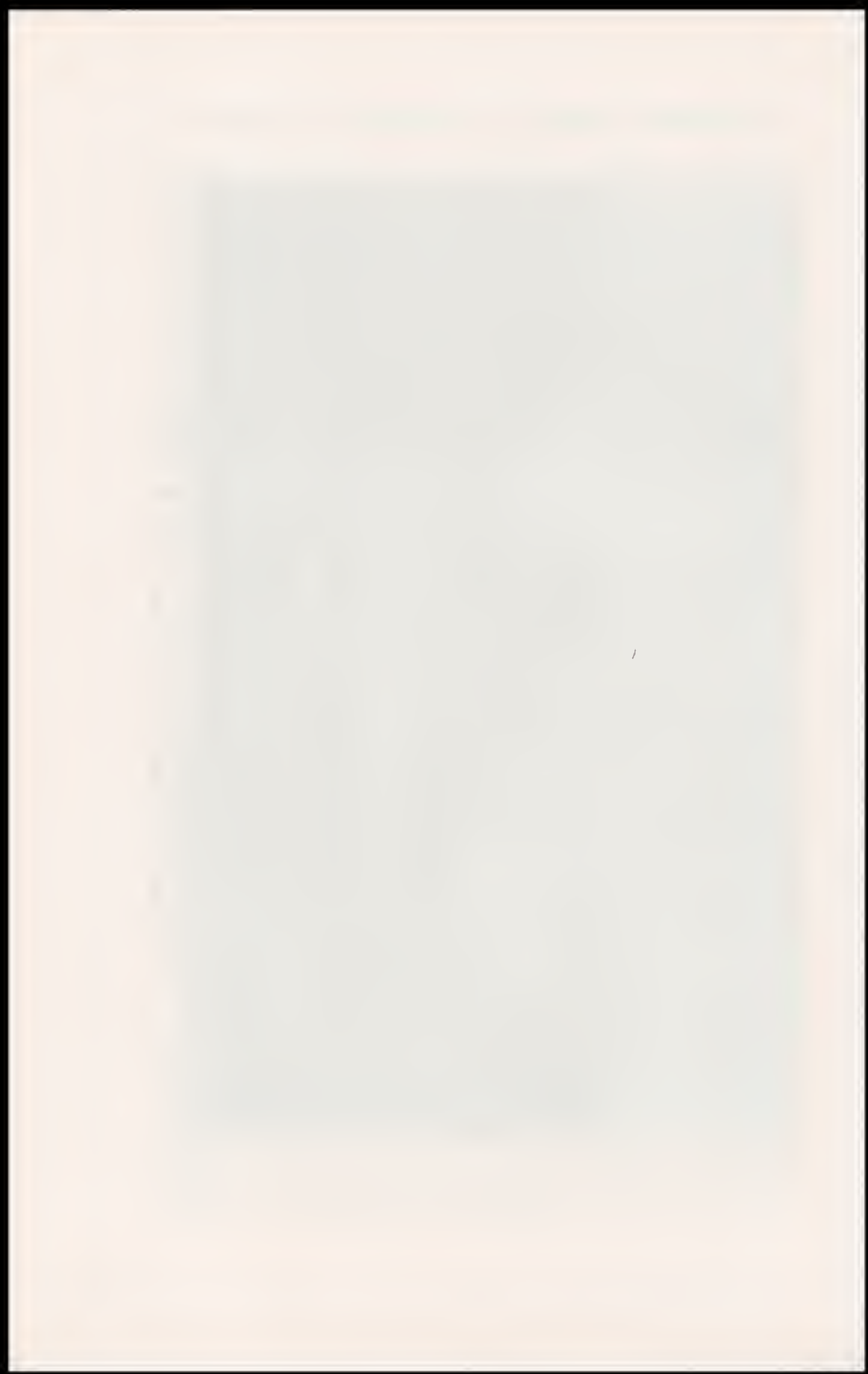


the foot of the Serra da Estrêla (SF-23, 43-23a). There, and in the city of Rio de Janeiro, especially in the Corcovado Mountain (1815-1816), as well as in the shore regions of the State of Rio de Janeiro, as far as Cabo Frio (SF-23, 42-23a), he collected many insects, which were sent to the Museum of the Russian Academy of Sciences, in St. Petersburg.

While Langsdorff collected insects in Rio, another Russian expedition explored the coasts of Brazil.

On 31 January 1815, the ship 'Rurick' had left St. Petersburg. sailing from Kronstadt, Denmark, on 30 July, for Copenhagen (17 August), and from Plymouth sailed for South America. Passing by Teneriffe on $2 \delta$ October, the expedition crossed the equator on the 23rd of November. The expedition was destined to a scientific study of the seas, especially of the Bering Strait, being financed by the Chancellor of the Russian Empire, Count von Romanzoff. The captain was Otto von Kotzebue, and two naturalists were present - Louis Claude Adelaide Chamisso de Boncourt (1781-1838), and, the one who interests us now, JOHANN Friedrich Eschscholtz.

Eschscholtz was born in Dorpat. Estland, on 1 November 1793, and died in the same city, on 19 May 1831. He was very well educated, having received a degree of Doctor of Medicine. At the time of his death he was Professor Extraordinary of Medicine and teacher at the University of Dorpat, Professor of Zoology and Director of the Zoological Museum of that same University, member of the natural history societies of Moscow and of the Leopold-Carolin Academy of Natural Research of Bonn, and Knight of the Order of St. Vladimir. He acted both as naturalist and doctor aboard the 'Rurick'.

On 6 December 1815, the 'Rurick' passed along Cabo Frio, and followed to the south, arriving in the neighborhood of the Island of Santa Catarina, where they landed on the 13th, in the same place where Krusenstern had anchored the 'Nadezhda' 12 years before. The following day, the naturalists went to the city of Destêrro (or Nostro-Senhor-dudesterro, as it was spelled by Kotzebue, the present city of Florianópolis; SG-22, 48-28a), a few hours from their landing place. There they were received by the Governor, Major Luis Mauricio da Silveira, and around the city they collected insects and made observations on physics and astronomy. They left the Island on 26 January 1817, sailing for Cape Horn.

After the passage of the Straits of Magellan, they sailed to Concepcion, where they were anchored on 11 February. In the port of Concepcion (SJ-18, 37-73d), they were visited aboard by 
Don Miguel de Rivas, Commander of Talcanuano ("Talcaguano" of Kotzebue; SJ-18, 37-73a), who marvelled at the Russian Imperial flag, seen for the first time in a Chilean port. They collected around the city, leaving for Kamtchatka on the 8th of March.

The narrative of the voyage was published by Kotzebue (1821). The specimens collected during that voyage were deposited in the Museums of Berlin and St. Petersburg.

In 1816, with Saint-Hilaire (see Chapter VIII), Langsdorff made a trip to the Province of Minas Gerais, passing through Vila Rica (now Ouro Prêto, SF-23, 20-44d). Mariana (SE-23. 43-20c). Catas Altas (SE-23, 43-20c). Inficionado, and Itajuru. There Langsdorff had to leave Saint-Hilaire and return to Rio de Janeiro.

Returning to Europe in 1820, in November he arrived at Paris, where he published a booklet destined to increase immigration to Brazil, entitled "Mémoire sur le Brésil pour servir de guide à ceux qui désirent s'y établir, par M. le Chevalier G. de Langsdorff, Consul général de Russie au Brésil, Membre de l'Académie Impériale des Sciences à Saint-Petersbourg et de plusieurs sociétés savantes" (20 pp.). From Paris he went to Germany. where he published a German edition of the same booklet, which appeared in 1821, with 107 pages. He gave his collections, made during 7 years of residence in Brazil, to the Berliner Zoologisches Museum. The value of the collection was calculated at 40,000 francs.

In the beginning of the spring of 1821 Langsdorff was in St. Petersburg. In February he was invested with the title of State Counsellor and with the Order of St. Vladimir, and was made an effective member of the Academy of Sciences.

Before returning to Rio de Janeiro, Langsdorff was encharged by the $C$ zar with the mission of making an expedition to the interior of Brazil. On 20 June 1821, he informed the Conference of the Academy of Sciences of the project, asking for special committments, and asked the Academy's permission to contract the entomologist Edouard Ménétriés and the artist Moritz Rugendas, whom he had met either in Paris or Bremen. The Academy had no special recommendations, and accepted the services of Ménétriés, who remained on duty until his death, in 1863.

Edouard MÉNÉTriẻs was born in Paris on 2 October 1802. He first studied medicine, but very soon, stimulated by the discoveries in the field of natural sciences in the beginning of the last century, abandoned medicine in order to work at the Museum of the Jardin des Plantes, under Cuvier and Latreille. Having 
met Alexander von Humboldt, and after having read his relations of travels, Ménétriés had also thought of going to some country to collect, when in 1821 Czar Alexander planned the expedition to Brazil under the direction of Baron von Langsdorff. He published "Observations sur quelques lépidoptères du Brésil" ("Mém. Soc. Nat. Moscou, vol. 7, 1829).

After the voyages in Brazil Ménétriés became established in St. Petersburg, being charged with the curatorship of the zoological collections of the Museum of the Academy of Sciences. In 1829 , by order of Nicholas I, he explored the Caucasus, being at that time only 27 years old. Returning from that trip, he studied the collections of the St. Petersburg Museum until his death on 10 April 1861, victim of a severe emphysema (Anon., 1863).

Some of his Brazilian collections were given to the Paris Museum, and were later studied by Macquart.

On his arrival in Brazil on 3 March 1822, Langsdorff found a changed political situation. The King, Dom Joāo VI, had returned to Portugal, and with him, a part of the diplomatic legations. Later, on 7 September 1822, his son, Dom Pedro de Alcântara, proclaimed the independence of Brazil, assuming the title of Emperor. After that, Langsdorff returned once more to Europe, making a trip to the Urals in 1823. During his absence, Ménétriés collected in the Provinces of Rio de Janeiro and São Paulo (Hagen, 1855).

In 1824, returning to Brazil, Langsdorff made a trip to Minas Gerais, accompanied by Rugendas and Ménétriès (Pinto, 1952). By the end of April they left Rio de Janeiro and crossed the Rio Paraiba, entering the Province of Minas Gerais. They passed by Barbacena (SF-23, 21-44d), where they stayed during May and June, the Serra da Mantiqueira, São Joāo del Rei (SF-23, 44-21c). Prados, Serra de São José, Vila Rica (Ouro Prêto, SF-23,44-20d). Serra de Itacolomi (SE-24, 44-19d; 18 August), Mariana (SF-23, 43-20c). Bento Rodrigues, Inficionado, Catas Altas (SF-23, 43-20c), Brumado, Serra do Caraça (SF-23, 43-20c). Gongo Soco (October). Caeté (SF-23, 43-22a), Rio das Velhas (SF-23, 44-20d). Sabará (SE-24, 44-20b). Santa Luzia (SE-23, 44-20b) (3-12 September), Lagoa Santa (SE-23, 44-20b). Serra da Lapa (16 October to 4 December). Congonhas (SE-23, 44-19b). Parauna, and arrived at the limit of their excursion, the city of Tejuco (now Diamantina, SE-23, 44-18d). on the llth of December. There they stayed until the 29 th, returning through Serra da Lapa (3 January 1825). Serra da Piedade, Vila Rica, Ouro Branco, Queluz (SF-23, 44-21b), Barba- 
cena, and Rio Paraibuna, to the city of Rio de Janeiro, where they arrived in February 1825. The insects collected on this trip also went to the Museum of Berlin, except for 6 boxes with several collections, made in 1824, which were received by the Academy of Sciences of St. Petersburg in August 1825.

The beginnings of a mental sickness in Langsdorff caused disagreements between the consul and his companions Ménétriés and Rugendas, who secured their dismissal, being substituted by the zoologist Christian Hasse and the artists Aimé Adrien Taunay and Hercules Florence.

Langsdorff decided then to launch the long-protracted expedition to the interior of Brazil, ordered by Czar Alexander I.

The party, composed by Langsdorff as the chief. Ludwig Riedel as botanist, Christian Hasse as zoologist, Aime Adrien Taunay and Hercules Florence as artists, and Rubzoff as astronomer, left Rio de Janeiro on 3 September 1825 aboard the ship "Aurora", and arrived in Santos (State of Säo Paulo) 48 hours later. Landing in that port, they proceeded, after a stay of 20 days, to Cubatão (SF-23, 46-24a), and to the City of São Paulo (SF-23, 47-24b), capital of the Province. From that city the commission went to Jundiai (SF-23, 47-23d). Itu (SF-23, 47-23c). São João de Ipanema (presently Varnhagen), and arrived in Pôrto Feliz (SF-23, 47-23c), where Langsdorff had decided to embark on the Tiete River (SF-23, 46-24b, 48-23d) in order to use the facilities of a river communication with the city of Cuiabá.

On 7 December, however, the commission was still stationed in Pörto Feliz, being always delayed by Langsdorff, who had to go to Rio to dispatch some important business. In his absence Riedel commanded the expedition, which explored the western parts of the Province of São Paulo. After 5 months, Langsdorff came back to join his companions, and finally, on 22 June 1826. they embarked. Meanwhile, the zoologist Hasse abandoned the expedition, and Langsdorff took over his functions as zoological collector.

The members of the expedition embarked on the Tiete in two big canoes, two small ones, and three 'bateloes' (large dugouts). with a crew of approximately 40 persons. They went down the Tiete (which runs westward) to its confluence with the Parana River ( $\mathrm{SF}-23,52-22 \mathrm{c}$ ). making a short digression to the waterfalls of Urubupunga. On 13 August they entered the Parana. and on the 18th the mouth of the Rio Pardo (SE-21, 54-20a). reaching Camapuã (SE-21, 54-19c), on 9 October. where they resided for 43 days. Then, the canoes were trans- 


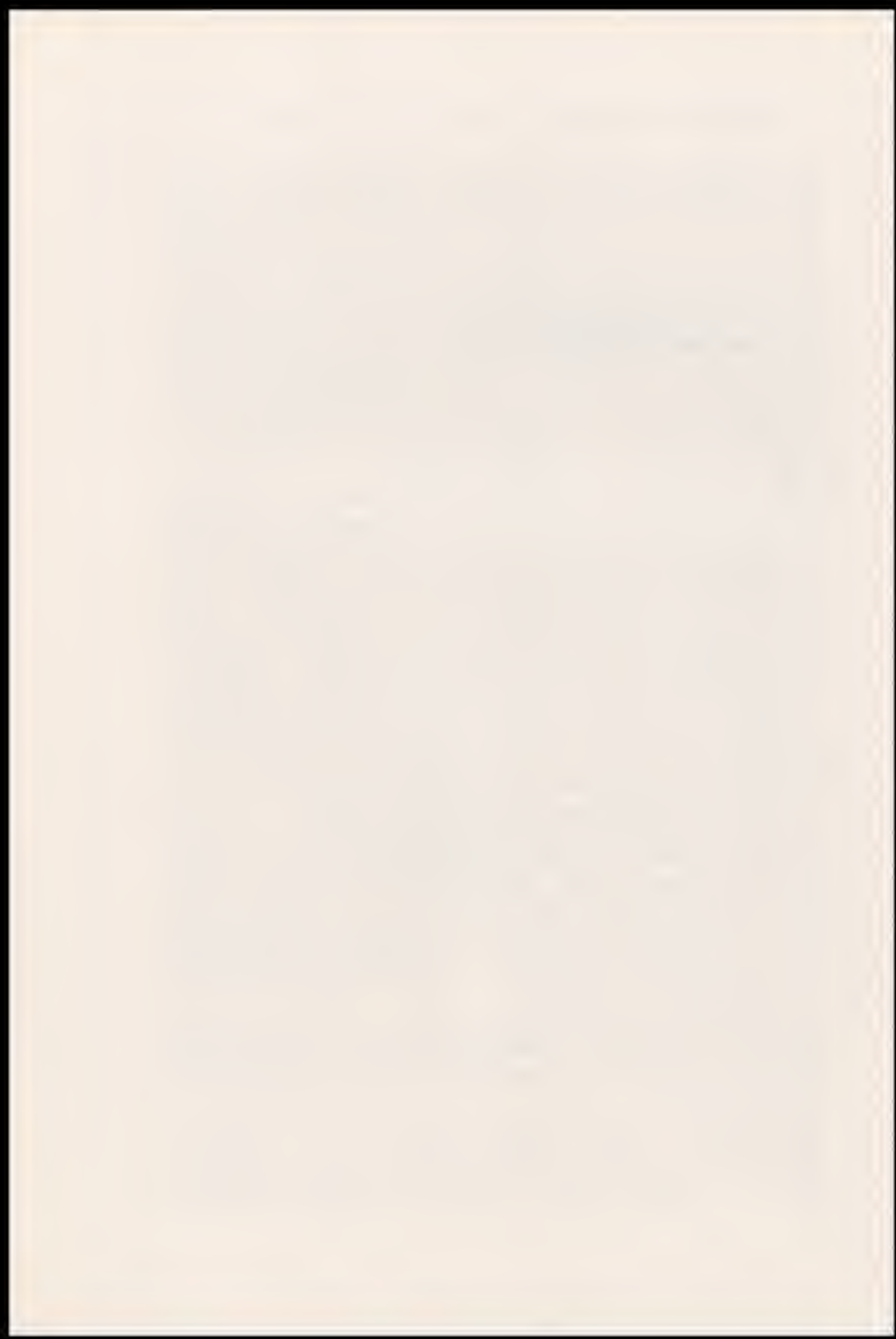

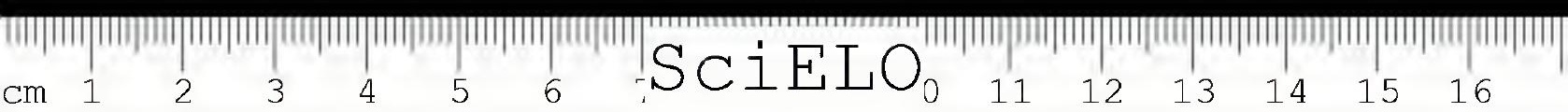


ported in wagons through mountainous regions, to the Rio Coxim (SE-21, 54-18c, 55-19b), where the scientists reassumed navigation. After portaging the many waterfalls of the Coxim, they entered the Rio Taquari (SE-21,54-18c) on 3 December, arriving at the Paraguay River (SE-21, 57-17c) on 12 December. On the 27th they entered the Rio São Lourenço (SE-21, 55-17a); on 4 January 1827 , the Rio Cuiaba (SE-21,56-16c), and finally landed in the city of Cuiaba (SE-21, 56-16a), the capital of the Province of Mato Grosso, on 30 January 1827, after seven and a half months of a painstaking voyage.

The important collections made during the first part of the trip were sent to Rio de Janeiro from Cuiabá, through a certain Sr. Angelini ${ }^{1}$, an Italian merchant who was going to Rio. The boxes with the specimens, reports, manuscripts, and drawings by Taunay and Florence were addressed to $\mathrm{Mr}$. Kielche, vice-consul of Russia in Rio de Janeiro. From Cuiabá, Langsdorff addressed a letter to the Academy of Sciences of St. Petersburg, with a catalogue of the ethnological artifacts, the observations on astronomy, meteorology and geography by $\mathrm{N}$. Rubzoff and the drawings made from June 1826 to January 1827 , representing birds existing in the collections. The letter was received on June 1828 and published in the St. Petersburgische Zeitung, n 52, of 29 June 1828.

The expedition stayed in Cuiabá until 6 December 1827. On the first day of May, they made a short trip to Chapada (dos Guimarães) (SF-21,56-21d), where they remained for one and a half months. While Langsdorff remained in Cuiabá, Riedel and Taunay went to Diamantino (SE-22, 53-17a), and Rubzoff and Florence to Vila Maria (Cáceres, SE-21, 58-16d), 40 leagues west of Cuiaba, on the banks of the Rio Paraguay.

By that time Langsdorff was mentally ill and causing serious troubles to the members of the expedition. They decided, be-

1 This Angelini, when young, had abandoned his parental home in Trieste, and travelled through Europe. Eventually he came to Brazil, in the times of D. Jošo VI, and began selling precious stones in the streets of Rio de Janeiro. Increasing his capital, he became very wealthy, and lived a grand life, inviting to his dinners contemporary ministers and ambassadors. By this means he may have known Baron von Langsdorff. Having a special bent for financial speculations, he went in 1827 to Mato Grosso, in order to do business in diamonds, thus meeting Langsdorff in Cuiabá, and bringing his collections to Rio de Janeiro. Later on Angelini travelled to the mines of Potosi, and became an intimate friend of Bolivar (Cenni, F., Os lialianos no Brasil, p. 53). 
cause of that, to divide the commission into two sections - one, composed of Langsdorff, Rubzoff, and Florence, to go to the north, and, leaving the vililage of Diamantino, descend the Rivers Preto. Arinos, Juruena, and Tapajós, arriving in the city of Santarém. and then proceed to Manaus; the second, composed of Riedel and Taunay, to go to Vila Bela (the city of Mato Grosso now) and. descending the Rivers Guaporé, Mamoré and Madeira, would meet the others in Manaus. Thence, both sections would ascend the Rio Negro to the Canal of the Casiquiare, and, through the Orinoco, try to reach the Guianas.

The project, however, did not succeed. Already in the village of Diamantino (SE-22, 53-17a), while the first section waited for the arrival of the other, the illness of Langsdorff became aggravated. The members of the expedition descended the Rio Arinos (SD-21, 56-14a, 56-14d), and remained for many months in a post of the Apiaca Indians. The stay in the Arinos proved fatal to the expedition - attacked by malignant fevers many lives were lost; Rubzolf, with beriberi, remained invalid for the rest of his days. There also Langsdorff lost his powers of reason completely. The remaining members descended the Rio Juruena (SD-21, 59-15a, 59-13c, 59-12d; SC-21, 59-11b, 58-9c; SB-21. 58-8a) and the Tapajós (SB-21, 57-5d; SA-21, 55-3a), reaching the city of Santarem (SA-21,55-2d), whence they sent Langsdorff to Belém, and then to Rio de Janeiro, in 1829.

In that same year the unfortunate naturalist was transported to Europe, and lived in Freiburg in Brisgau until 29 June 1852. without regaining his sanity. Nicholas I, with the generosity of the Russian autocrats, and as a homage to the memory of his brother, who had had the idea of this ill-fated expedition, granted Langsdorff a pension during his lifetime (Florence, 1942; Garcia, 1922: Hoehne, 1942; Ihering, 1902; Manizer, 1967; Stresemann. 1950; Urban, 1908).

\section{Sellow and Freyreiss}

Langsdorff was one of the most enthusiastitc naturalists in Brazil. Almost every collector during the First Empire had some advice or substantial help from him. One of the naturalists aided by Baron von Langsdorff was F. Sellow.

Friedrich Sellow (or Sello) was born on 12 March 1789. in Potsdam, Germany, son of Carl Julius Samuel Sello, a royal gardener of the Sanssouci. Friedrich practiced gardening 
with his uncle, Johann Wilhelm Sello, and was employed as auxiliary gardener at the Botanisches Garten in Berlin. There he met Wildenow, then occupied with the study of the American plants brought by Humboldt and Bonpland. Through Wildenow. Sellow went to Paris, working at the Jardin des Plantes, studying botany under Jussieu and attending classes of Cuvier, Haïy, Lamarck, and Godeffroy. Helped by Baron Alexander von Humboldt, he was transferred to England, in 1811, where he utilised the facilities of the library of Sir Joseph Banks. In London, Sellow studied zoology with Leach and Koenig.

In January 1813, he became acquainted with Baron Langsdorff, who was in the stage of final preparations to go to Rio de Janeiro as Consul of Russia. Sellow was invited to join him, but for financial reasons, his acceptance was impossible. However, Sir Joseph Banks and Dr. J. Sims offered to finance his voyage, and Sellow embarked for Brazil in 1814.

Arriving in Rio de Janeiro, Sellow went to live in the house of Langsdorff, learned Portuguese, and in his first year of residence made frequent excursions in the surroundings of the $\mathrm{Ca}$ pital, going also to Petrópolis (SF-23, 43-23a), to the Farm Mandioca. Serra dos Órgãos (SF-23, 43-22d, 42-22c), and Sumidouro ( $\mathrm{SF}-23,43-22 \mathrm{~d}$ ). In the city of Rio de Janeiro his favorite place was the forest-clad Corcovado Mountain. He also visited the coastal regions of Angra dos Reis ( $\mathrm{SF}-23,44-23 \mathrm{c}$ ) and probably also Macaé (SF-23, 43-22c) and Cabo Frio (SF-23. 42-23a). The collections made during those trips were sent to Banks and Sims as a compensation for their financing.

As Sellow was now free from his obligations to the English zoologists, Langsdorff suggested that he go to the northern regions of Brazil. The trip would be financed by Langsdorff, who in turn would keep the zoological collections for himself. Sellow was ready to start on his trip when another naturalist arrived in Rio: G. Freyreiss.

GEORG WILHELM FREYREISS was born in Frankfurt on 12 July 1789. In 1812 he had left Russia with Langsdorff, but as the trip had been a tiresome one, he remained in Carlshamn, Sweden, and went on to Uppsala. There he met the eminent botanist Swartz, and Thunberg. The latter furnished Freyreiss with letters of recommendation to the General Consul of Norway and Sweden in Rio, LORENTz WestiN, also an amateur entomologist. who had sent some insects to Thunberg.

Once in Rio. Freyreiss became a good friend of Westin, who did everything to help him to travel and collect natural history specimens. In July 1814. Freyreiss went to Minas Gerais, pro- 
fiting by a trip made by Wilhelm von Eschwege, then the director of the mining companies of Brazil, by appointment of the Brazilian Government, and one of the most learned students of Brazilian geography and natural resources.

Leaving Rio on 29 June 1814, Eschwege and Freyreiss took a boat as far as Pôrto Estrêla, crossed the Serra dos Órgãos. and after crossing the River Paraibuna, entered the Province of Minas Gerais, via Juiz de Fora (SF-24, 44-21d), Chapéu d'Uvas (SF-23, 44-22b). Barbacena (SF-24, 44-21d; which they left on 7 August). Congonhas do Campo (SF-23, 44-20d), to Vila Rica (presently Ouro Prêto, SF-23, 44-20d), where Eschwege had his headquarters.

Leaving Vila Rica on the 2nd of September, Freyreiss returned to Congonhas do Campo, and went on to the Rio $\mathrm{Pa}$ raopeba (SE-23, 44-20a; SF-23, 44-20c), visiting two farms (Bicas and Varginhas), the city of Pompeu (SE-23, 45-19c; on 10 and 11 September), the Rio São Francisco (SE-23, 45-18a; SE-23, 44-18a), the village of Santana (SE-23, 43-20a), and the Rio Indaiá (SE-23, 46-19b, 46-19d; SF-23, 45-20c). He returned to Vila Rica, going to visit a lead factory situated 80 leagues away of that city, where he remained for a month, which he dedicated to "the discovery of the most important objects of natural history".

On 22 December 1814, he again left Vila Rica for another trip, at this time passing by Mariana (SF-23, 43-20a). Serra do Itacolomi (SE-23, 44-19d), Santana dos Ferros (?), Santa Rita (SE-23, 43-19b), Presidio de São Joāo Batista (?). This voyage was made with the sole purpose of studying Indian tribes (Freyreiss, 1902, 1907).

On his return to Rio, after meeting Sellow in Langsdorff's house, Freyreiss decided to join the trip which was being planned. Sellow and Freyreiss received letters of recommendation to the authorities of the Brazilian Provinces, and the title of "financed naturalists". granted by the Brazilian Government, with an annual pension of 400:000 (400,000 'reis'). Everything was ready for the trip, when in July, 1815. Prince Maximilian zu Wied-Neuwied, who was also a naturalist, and was interested in undertaking a trip to the interior of Brazil, arrived in Rio de Janeiro. Wied-Neuwied, who was a guest of Baron von Langsdorff, decided to accompany Sellow and Freyreiss in their voyage.

The three naturalists left Rio de Janeiro on 4 August 1815. taking 13 beasts of burden with the equipment, and 10 servants. From São Cristóvão (now a district of the city of Rio de Ja- 
neiro), they went by the coast to Cabo Frio (SF-24, 41-22a), Macaé (SF-24, 42-22d), and Campos (SF-24, 41-22a), with a short trip up the Rio Paraiba, to visit a village of the Puri Indians. Entering the Province of Espirito Santo, they reached Vitoria (SF-24, 40-20c) in November 1815. There Sellow and Freyreiss decided to stay for some time, collecting more specimens, while the Prince proceeded to the north, to Caravelas (SE-24, 39-18a).

Sellow and Freyreiss stayed in Vitória for some 6 months, occupied with the collection of plants and animals (until June 1816). Near the Rio Mucuri (SE-24, 40-18d), they again met the Prince. Arriving in Salvador, in Bahia (SD-24, 38-13c), Wied-Neuwied considered that his collections were sufficient, and departed for Europe on 10 May 1817. His book of travels (1820-1821) is one of the best ever written about Brazil (for a gazetteer of Wied-Neuwied's voyage, with annotated localities. see Bokermann, 1957).

Sellow, in no hurry, camping frequently, and always collecting, passed by way of Caravelas (SE-24, 39 18a) in December, 1816, Pôrto Seguro (SE-24, 39-16d). Belmonte, Una (SE-24, 39-15c), Olivença (SE-24, 39-15b), and reached Salvador (SD$-24,38-13 \mathrm{c}$ ) at the end of 1817, staying afterwards in Nazaré (SD-24, 39-13c).

Freyreiss returned to Rio de Janeiro. From the trip through Espirito Santo and Bahia he sent three shipments to the Berliner Zoologisches Museum:

1. The first in March 1816, from Vitória;

2. The second in September 1816, from Caravelas;

3. The third in January 1817, also from Caravelas.

He made four more shipments of collections of specimens collected in Salvador, between July 1817 and August 1818, comprising in the total 2,000 bird skins and 8,000 insects.

Freyreiss contributed later to the foundation of a German colony in southern Bahia (Colonia Leopoldina), where he died in 1825. In 1824, he published his "Beyträge zur Kentniss der Kaiserthums Brasiliens". His collections were distributed among the museums of Stockholm. Uppsala, Moscow, Berlin, Leyden, Hannover, and Frankfurt (Senckenberg).

Sellow still remained in Bahia. In a letter dated $15 \mathrm{De}$ cember 1817, to the Prussian Minister of Culture, Karl Freiherr von Altenstein, he offered his services as collecting naturalist to 
the Berliner Museum. If his proposal was accepted, he asked that the funds be sent in the name of Count von Elemming, in Rio de Janeiro. By Humboldt's influence, his request was granted, and Sellow received instructions from the professors of botany and zoology, Lichtenstein and Link, with a credit of 8,000 marks, payable at a rate of 4,000 a year. On 7 May 1818, this news was communicated to him in Bahia by von Altenstein. He collected a little more in the surroundings of Salvador, and sent from there, on 4 October 1817,600 skins of birds, 3,000 insects, 300 species of plants (with 4 to 6 specimens of each species), and several kinds of seeds, collected between Caravelas and Salvador between December 1816 and July 1817. Lichtenstein received that collection in Berlin on 25 March 1818. This may have induced Lichtenstein to accept Sellow as a collector.

After the receipt of the letter by von Altenstein. Sellow sent a new collection, also from Salvador (made from September 1817 to May 1818), and this shipment arrived at the Museum of Berlin on 25 September 1818. After that he returned to Rio de Janeiro.

We shall now leave Sellow for a while to consider the expeditions of the Austrian scientists, and we shall return to the other journeys undertaken by him.

\section{The Austrian expeditions}

In 1817, several events resulted in the coming of still more zoologists to study the Brazilian fauna.

Dom João VI had sent his Ambassador, the Marquis of Marialva, to beg the hand of the Archduchess Leopoldina Carolina Josefa of Austria for the crownprince, Dom Pedro de Alcantara, the future Emperor of Brazil. Kaiser Friedrich I conceded, and Count von Wrbna was immediately sent to Rio de Janeiro with the good news from Vienna.

The Chancellor of the Austrian Empire, Prince von Metternich-Winneburg, was responsible for the organization of a scientific commission which would join the train of the Archduchess on her departure to Brazil. Those scientists were to explore the Brazilian Kingdom, making collections of animals, plants, and minerals, investigating the productions of the countries visited, the culture, the inhabitants, etc. Counsellor Ritter von Schreibers, Director of the Imperial and Royal Cabinet of Natural History 
in Vienna, was to report the activities of the scientific commission upon its return to Austria.

The Austrian commission was composed of the zoologist Johann Natterer, the Imperial hunter Dominick Sochor, the mineralogist and botanist Johann Emmanuel Pohl, the entomologist and botanist Johann Christian Mikán, the painter of plants Johann Buchberger, the royal gardener Heinrich Wilhelm Schott, the painters Thomas Ender and Franz Joseph Frübeck, and the librarian Rochus Schüch, who had been until then curator of the cabinet of natural history in Vienna. Dr. Johann Kamerlacher, also a naturalist, came as the private doctor of the Archduchess.

At the instance of the House of Tuscany, the botanist Giuseppe Raddi, who arrived with the Grand Duke Karl August of Saxony-Weimar, joined the scientific commission.

King Maximilian Joseph I of Bavaria, who had had since 1815 the idea of sending a scientific expedition to South America, took the occasion to send the zoologist Johann Baptist von Spix and the botanist Karl Friedrich Philip von Martius.

The Archduchess left Vienna on 2 June 1817, and proceeded overland to Livorno, sailing on 5 August aboard the Portuguese corvette 'Dom Joāo VI'. Pohl and Raddi also sailed from Livorno, aboard the warship "São Sebastiāo", with the Grand Anbassador Count von Eltz.

Mikán and his wife, Ender, Spix, Martius, the counsellor of the Austrian Embassy, Baron von Neveu, and the Counts von Schönfeld and von Palfy, embarked on the frigate 'Austria'; Natterer, Buchberger, Schott, and Sochor, aboard the 'Augusta'. Both frigates sailed from Trieste on 10 April 1817.

On the arrival in Rio, the naturalists intended to make a joint expedition to the interior of the country, but several reasons having rendered the plan impossible, each group took a separate route.

Johann Christian Mikán, born on 5 December 1769, in Teplitz, Bohemia, studied medicine in Prague, and obtained his title of 'Doctor Medicinae' in 1793. His dedication to entomology and botany obtained him the post of professor of natural history in the University of Prague in 1800. In 1812 he replaced his father in the chair of botany. His travels in Brazil, which he undertook with Schott and Buchberger, were limited to the City of Rio de Janeiro (Corcovado, Boa Vista, Laranjeiras, etc.). the regions of Saquarema (SF-23, 43-23b), and Cabo Frio (SF-24. 41-22a). He left Rio on 1 June 1818, and died in Prague on 24 December 1844. His collections are kept in the Museum of Vienna (Urban, 1908). 
Johann Emmanuel Pohl, born in Kanitz, Bohemia, on 22 February 1782, was also laureated in medicine, in 1808, and professor of botany in the University of Prague. He died on 22 May 1834, as curator of the Imperial and Royal Brazilian Museum of Vienna, where were deposited the collections made by the Austrian scientists.

During his first weeks in Rio de Janeiro (he arrived on 7 November 1817), he collected around the city, and tried several techniques to preserve the zoological and botanical collections from the ants, termites, and humidity.

On 15 February 1818 he started a new journey going first to Sepetiba (SF-23, 44-23b), where he met Natterer. On the 4th of March he visited the Ilha da Madeira (SF-23, 44-23b), and on the next day went to Itaguai (SF-23, 44-23b) and Pirai (SF-23, 44-23b). On 19 March he started to Angra dos Reis ( $S F-23,44-23 c)$, where he arrived only on the 25 th, due to the heavy rains, that rendered the roads almost impracticable.

From Angra dos Reis he went by sea to Mangaratiba (SF-24, $44-23 b)$ and returned to Sepetiba, where Natterer was waiting for him. On the 5th of April he arrived in Rio. There he learned that Buchberger had suffered a severe accident, falling from his mule - a branch of a tree had wounded his abdomen, causing internal damage. Due to this unfortunate accident, Mikán. Ender and Raddi had returned to Rio. The collections gathered thus far were arranged and packed, and on the lst of July 1818 . when the Grand Ambassador Count von Eltz returned to Europe, Buchberger, Mikán, Ender and Raddi embarked with him, taking the collections.

Buchberger was installed in the Imperial palace in Schönbrunn, where he died in January 1821. Karl von Schreibers received the collections, and wrote a notice about them in a booklet published in Brünn (1820).

After the departure of von Eltz, Baron von Neveu, now plenipotentiary Minister from Austria, took up the direction and the financing of the expeditions of the remaining members.

On 6 September 1818, furnished with the portarias authorizing his voyages through Minas Gerais and Goias, Pohl left Rio de Janeiro, and went to Pôrto Estrêla. After collecting in the Farm Mandioca, he passed the Serra dos Órgāos, and the Paraibuna River, entering the Province of Minas Gerais.

Pohl travelled through Simão Pereira (SF-23, 43-22a), Matias Barbosa (SF-23, 43-22a). Chapéu d'Uras (SF-23, 44-22b) (28 September), Barbacena (SF-24, 44-21d), where he remained 


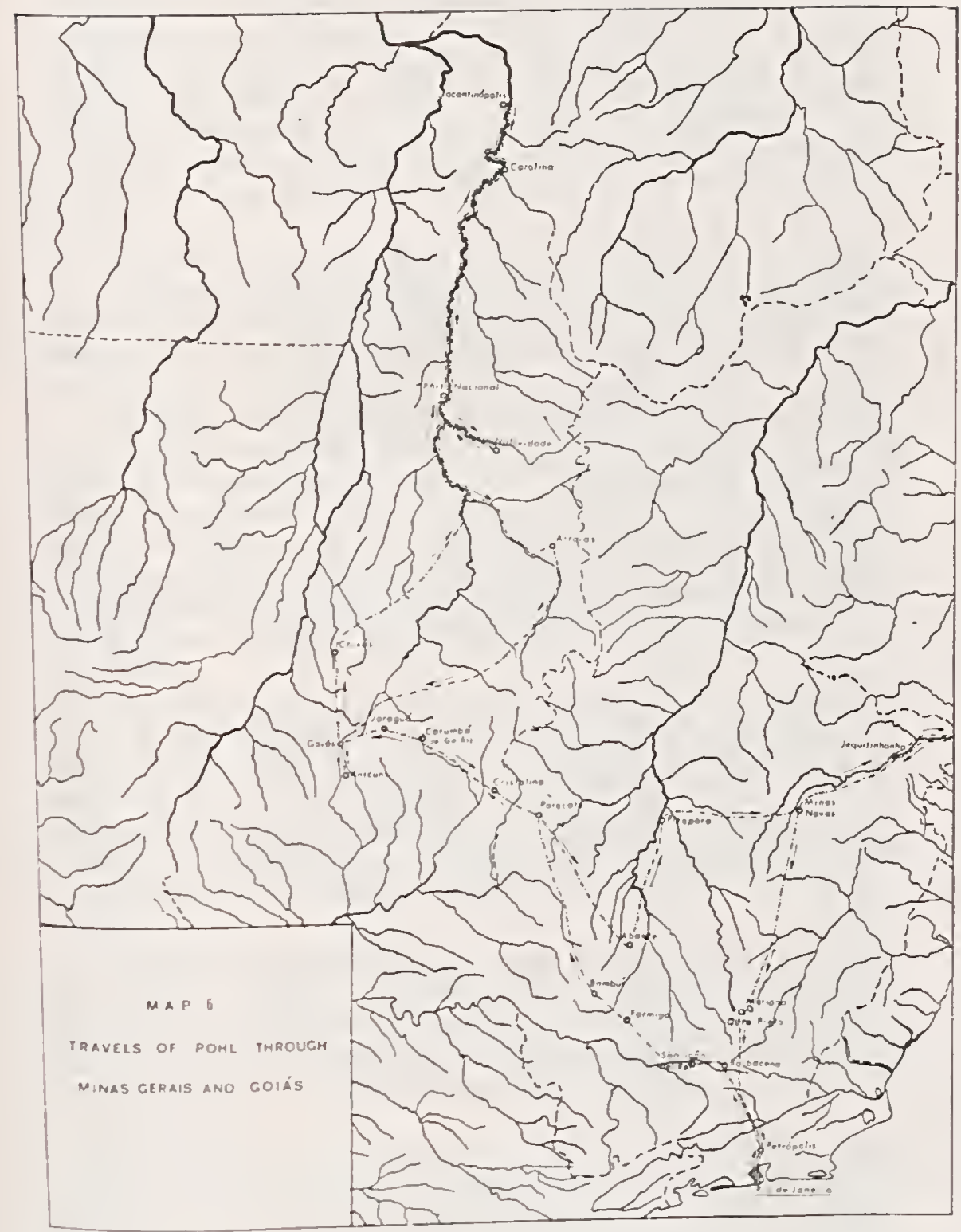

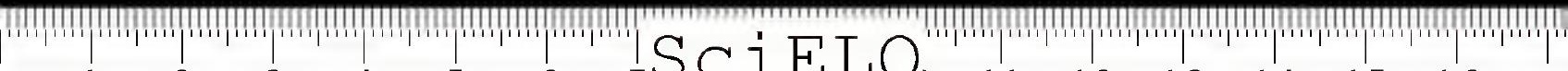
$\mathrm{cm} 1$ 


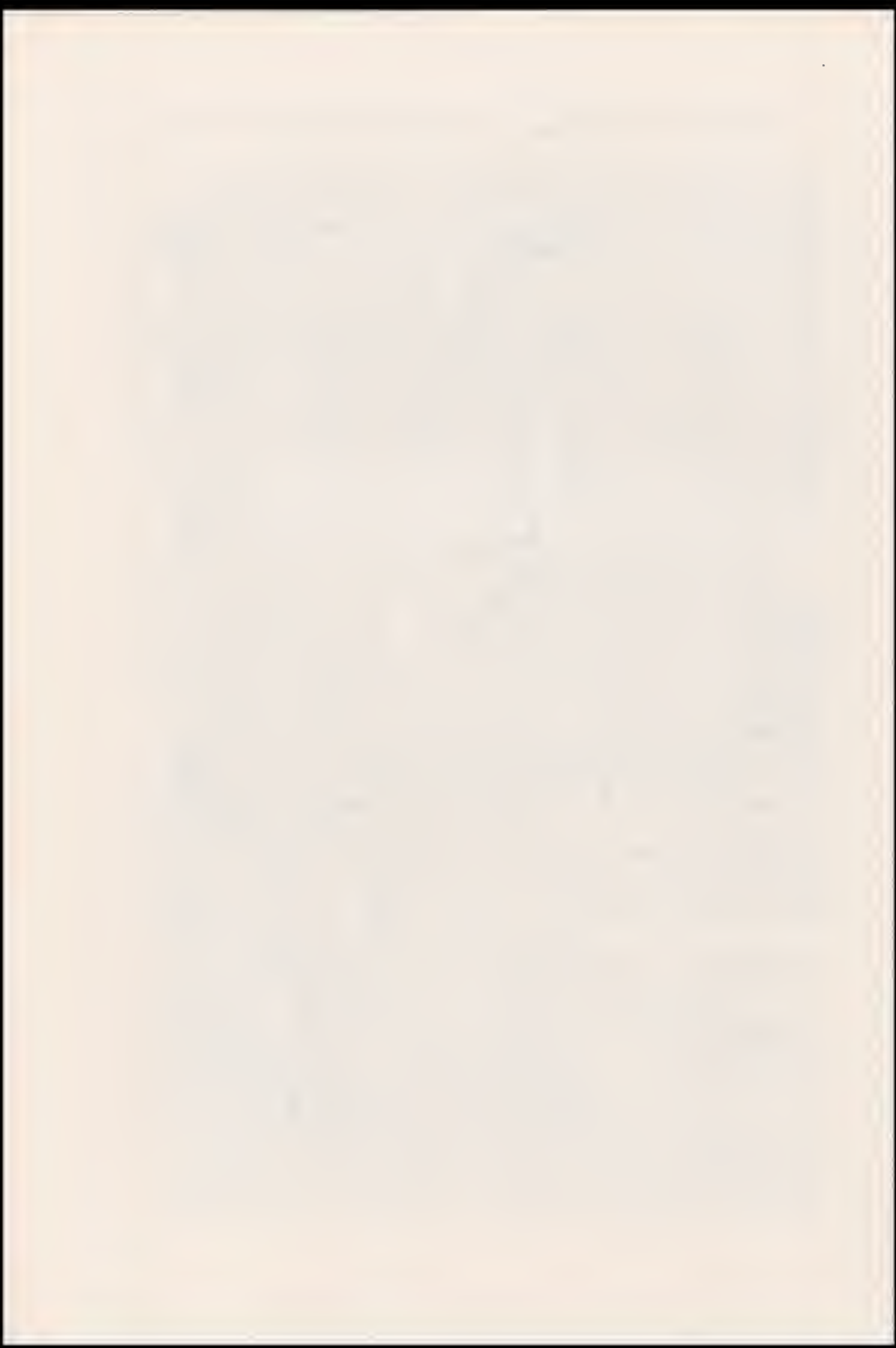

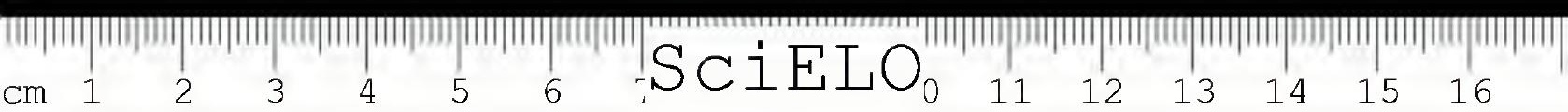


from 1 to 11 October, and São João del Rei (SF-23, 44-21c), whence he sent to Rio the collections gathered in this first part of the trip. On 21 October 1818 he left that city, and proceeded to Formiga (SF-23, 45-20c) (31 October), Bainbuí (SF-23, 46-20b). Guarda-Mor (SE-23, 47-18a). and Paracatu (SE-23, 47-17d) (25 November). From Paracatu he visited the Serra dos Cristais, where he went to investigate the mineral productions, and arrived at Santa Luzia (?), sending again collections to Rio de Janeiro.

Already in the Province of Goias, Pohl journeyed to Corumbá (de Goiás, SD-22, 49-16b), crossed the Pirineus Mountains, proceeding to Jaraguá (SD-22, 49-16a) and Vila Boa (presently the city of Goias, SD-22, 50-16a), where he arrived on $23 \mathrm{Ja}$ nuary 1819.

With the arrival of the rainy season, he was forced to remain for some time in Goiás, and also had to wait to buy new beasts of burden, which had to come from Mato Grosso or São Paulo. In the meantime, he went to Anicuns (SE-22, 50-16d) to investigate gold mines, returning to Vila Boa in the middle of March. and again, desirous of seeing the mining of diamonds, proceeded on 22 March to São José de Mossâmedes (Mossâmedes, SE-22. 50-16c), and to Piloes (SE-22, 51-16d), on the Rio Claro, on the 28th.

He left Vila Boa (Goiás) on 22 April, resuming his trip. and going to Santa Rita (27 April), Crixás (SD-22. 50-14d) (18 May). Ouro Fino, Agua Quente (28 May). Trairas, on the banks of Rio Trairas (SD-22, 48-15a), where he remained for some time, making excursions in the surroundings, collecting minerals and exploring caves. There he left the collections of natural history, to be taken to Vila Boa and then to Rio, and left on 28 June.

Following the upper course of the Rio Tocantins, he passed by São Fẻlix (4 July). São Joāo da Palma, on the banks of the Rio da Palma (SD-23,46-13a, 47-12c), where he again left his recently gathered collections, and left on $20 \mathrm{July}$, proceeding to Pörto Real (now Pôrto Nacional, SC-22, 48-11a), arriving on 1 August 1819.

He decided then to travel on the Rio Tocantins (called "Maranhão" by Pohl. SC-22, 48-10c, 49-12b), and descended it as far as São Pedro de Alcântara (Tocantinópolis, SB-23, 48-6d). Returning the same way via the river, he explored several of its tributaries - by the Rio Manuel Alves (SC-23, 47-12a, 48-12b) he went to Natividade (SC-23, 48-12b); by the Rio da Palma 
(SD-23, 46-13a, 47-12c) and by the Rio das Arraias (SC-23, 48-9d; SD-23, 47-13a) to the village of Arraias (SD-23, 47-13b); via the Rivers Paranã (SD-23, 48-13b) and Campos Belos (SD-23. 47-13d) to Chapéu. He also explored the rivers Prêto (SD-23. 48-14d). Tocantinzinho (SD-23, 48-14d, 47-14c; SD-22, 48-14c). da Bagagem (SC-23, 48 12b), and, overland, after crossing the Rios Maranhäo and dos Patos (SD-22, 49-16a, 49-15d), he returned once more to Vila Boa (6 December 1819).

Leaving the capital of the Province of Goias definitely on 15 April 1820, where he had waited for the end of the rains, he returned to Paracatu and went on to Abaeté (presently São Gonçalo do Abaeté, SE-23, 46-18d), where he arrived on 4 July. Afterwards he followed the Rio Säo Francisco to Pirapora (SE-23, 45-17d; 22 July), and Barra do Rio das Velhas (presently Guaicu). On the 28th he left Barra, and arrived on the 30 th to Jequitai (SE-23, 45-17d). Proceeding to the east, after having crossed the Rios Jequitinhonha and Araçuai. Pohl arrived at the Vila do Fanado (Minas Novas, SE-23, 43-17d) on 13 August. leaving on the 19th, and, following the Rios Setúbal, Araçuai and jequitinhonha, reached São Miguel (now Jequitinhonha, SE-24, 41-16d). From Sảo Miguel he navigated down the Jequitinhonha River, to Salto Grande (now Salto da Divisa, SE-24, 40-16c). arriving on 7 September. The village of Salto Grande situated between the Province of Minas Gerais and Pôrto Seguro (Bahia). marked the easternmost point of his trip. Thence he departed for São Miguel and Fanado, arriving in the latter city on 17 November, and still making several excursions in the neighborhood.

Deciding that it was time to return to Rio de Janeiro. Pohl proceeded southwards, through Vila do Principe (Sêrro, SE-23. 43-19a). Itapanhoacanga (SE-23,43-19a). Itambé do Mato de Dentro (SE-23, 43-19c). Bento Rodrigues (SF-23, 43-20c), Camargos (SF-23, 43-20c), Mariana ( $\mathrm{SF}-23,43-20 \mathrm{a}$ ). Vila Rica (Ouro Prêto; SF-23, 44-20d; 4 December 1820). where he remained until 7 February 1821, resting and collecting. Queluz (Queluzita, SF-23, 44-21b), Barbacena (SF-23, 44-21d), and, crossing the Rio Paraibuna, entered the Province of Rio de Janeiro, arriving in Rio on 28 February 1821.

In Rio he again met Natterer and Schott, who had returned from their voyage to Säo Paulo, and a month afterwards Pohl returned to Europe. Although primarily a botanist and mineralogist, he also collected some animals.

In Austria he published the first volume of his book of travels (1832), but died before the publication of the second, which was printed by order of the Emperor, in 1837. 
Included in his "Reise" there is a short paper on Brazilian arthropods, coauthored by V. Kollar - "Vorzüglich lästige Insecten - in which Simulium pertinax is described.

The Bavarian naturalists KarL Friedrich PhiLjp voN MARTuus (born 17 April 1794 in Erlangen, northern Bavaria; died in Munich, 13 December 1868) and JoHAnn BAptist von SpIx (born 9 February 1781 in Höchstadt; died 14 March 1826 in Munich), after some weeks in Rio, where they made the acquaintance of Krusenstern and Langsdorff, decided to initiate their trip through Brazil.

Through Baron von Neveu they obtained permission to enter the Brazilian Provinces (see Appendix I). They collected in the city of Rio de Janeiro (Laranjeiras, Corcovado, Aqueduto, Fonte da Carioca (where the English Consul, Mr. Chamberlain, an amateur entomologist, had a coffee plantation). Tijuca, Botafogo, Jardim Botânico). Invited by Langsdorff, they spent some days at the Farm Mandioca, and continued for a distance on the road to Minas Gerais, to a farm not too far from the Rio Paraiba.

Upon their return to Rio, informed by Count von Wrbna that they could not stay in Brazil for more than two years, they decided to go immediately on their expedition.

After acquiring mules for the transportation of the equipment, they went through Itaguai (SF-23, 44-23b) (13 December 1817), Areais (already in the Province of São Paulo, SF-23, 45-23a), Lorena, Guaratinguetá (SF-23, 45-23a), Aparecida (SF-23, 45-23a, 46-23b), Pindamonhangaba, Taubaté (SF-23, 46-23c), Jacarei (SF-23, 46-23d). Mogi das Cruzes (SE-23, 46-23c), arriving in the City of São Paulo (SF-23, 47-24b) on 31 December 1817. In São Paulo they met Count von Wrbna, Thomas Ender (who had been making drawings along the Rio-São Paulo road), Prince von Thurn und Taxis, and Count von Palfy, who had come with the Archduchess' train.

Leaving São Paulo on 9 January 1818, they proceeded by way of Cotia, São Roque (SF-23, 47-24a). Sorocaba (whence they sent collections of natural history to Sảo Paulo and Rio), Ipanema (now Varnhagen). Pôrto Feliz (SF-23, 47-23c), then returned to Sorocaba (SF-23, 47-24a), and proceeded to Itu (SF-23, 47-23c). Jundiai (SF-23, 47-23d), and Atibaia (SF-23, 47-23d), all in the Province of São Paulo.

Entering Minas Gerais, Spix and Martius journeyed through Camanducain (SF-23, 46-23a), crossed the Rio Sapucai (SF-23, 46-22b). continued along São Gonçalo (do Sapucai, SF-23, 46-22b). Campanha (SF-23, 45-22a) (14 February 1818), crossed 
the Rio do Peixe and the Rio Grande, passing by São João del Rei (SF-23, 44-21c), and arrived at the then capital of the Province of Minas Gerais, Vila Rica (Ouro Prêto, SF-23, 44-20d).

From Vila Rica they went to visit a village of the Coroado Indians, and afterwards continued their trip via Mariana (SF-23. 43-20a; 21 April 1818). whence they visited the Serra do Caraça, and returned on the 28th to Vila Rica. Through the Governor, Manuel de Portugal e Castro, they dispatched the collections gathered in the itinerary between Sorocaba and Vila Rica.

On 1 May 1818, they left the capital of the Province, and went on to Sabará (SF-23, 44-20b), Caeté (SF-23, 43-22a, at that time also called Vila Nova da Rainha), Vila do Principe (Sêrro, SE-23, 43-19a). Tejuco (Diamantina, SE-23, 44-18d), Fanado or Bom Sucesso (presently Minas Novas, SE-23. 43-17d). Montes Claros (SE-23, 44-17a), and Contendas (Brasilia de Minas, SE-23,44-16c), where they remained for some time, for that region was very rich in zoological specimens, and left on 12 August 1818. Following a N-NE direction, they crossed the Rio São Francisco and the Rio Carinhanha, entering the present State of Bahia (at that time a part of the Province of Pernambuco), going as far as the Serra Geral, and returning by Cócos (SD-23, 45-4d) to Carinhanha (SD-23, 44-14d) and Malhada (SD-23, 44-14d).

Proceeding through the Province of Pôrto Seguro or Bahia, they passed by Vila Nova do Principe or Caitité (SD-23. $\$ 3-14 d$ ). Rio das Contas (SD-24, 42-14b; which they left on 17 October 1818). Maracás (SD-24,40-13c). São Félix, and Cachoeira, on the banks of the Rio Paraguaçu (SD-24. 39-13b). Navigating the Paraguaçu downstream, after passing the Island of Itaparica, they arrived at the capital of the Province, Salvador (SD-23, 38-13c), on 10 November 1818.

From Salvador, on 11 December, they went to Ilhéus (SD-24, 39-15b). S. Pedro de Alcântara (now Itabuna, SD-24, 39-15a). and Almada; then returned to Ilheus, and along the coast, proceeded to Maraú (SD-24, 39-14d), returning to Salvador by sea.

In Salvador they received letters from von Neveu, with the permission, which they were anxious to receive, to travel to the Province of Maranhào, and the money necessary for the trip. In Salvador they left the boxes with the collections, which should be dispatched to Hamburg.

On 18 February 1819, they left Salvador, and passed by Cachoeira (SD-24, 39-13b), Feira de Santana (SD-24, 39-12d; Ist of March), and Arraial do Coité (presently Conceição do 


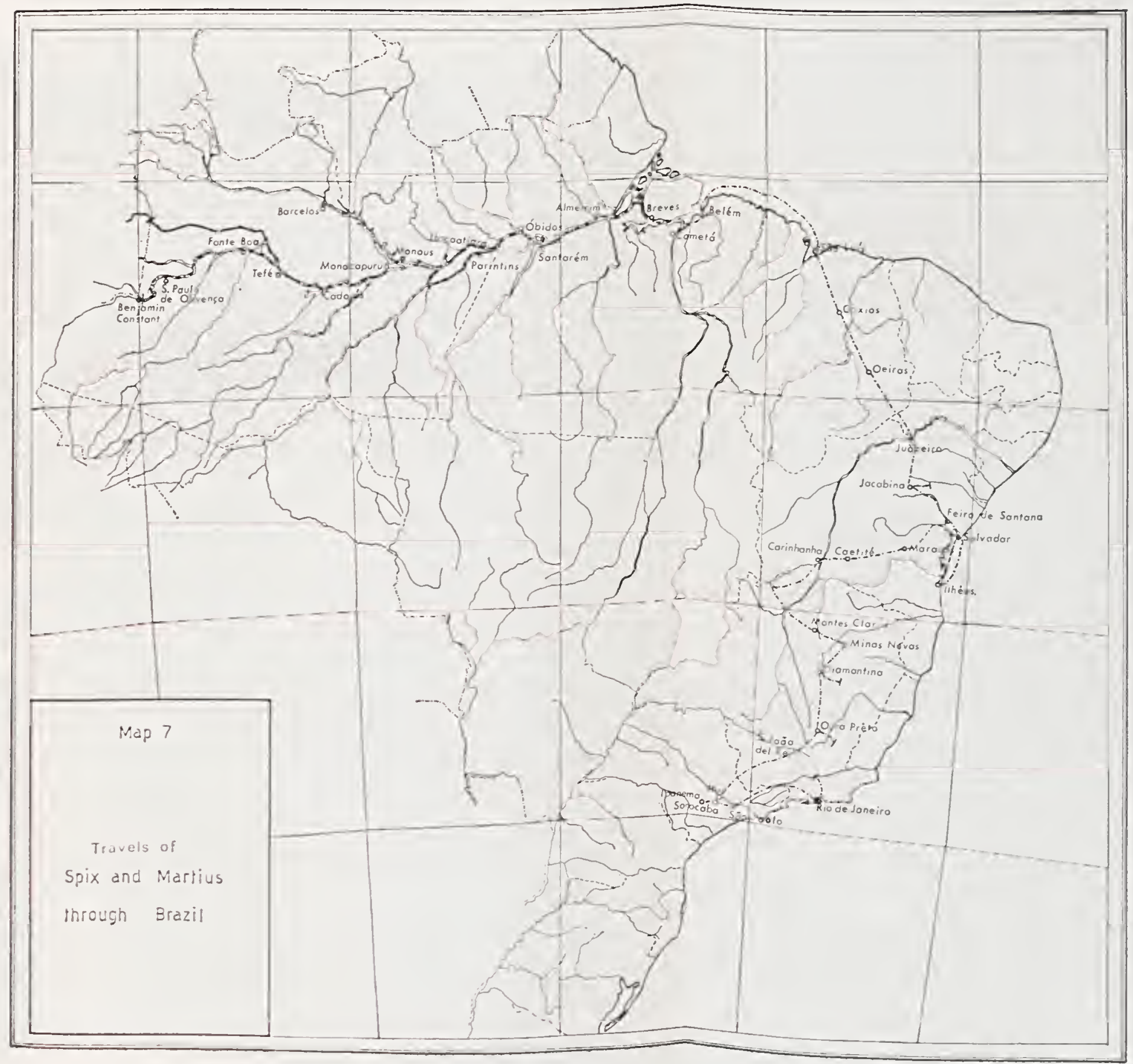

P. $\mathrm{cm}$

$\begin{array}{llllllllll}2 & 3 & 4 & 5 & 6 & 7 & 8 & 9 & 10 & 11\end{array}$




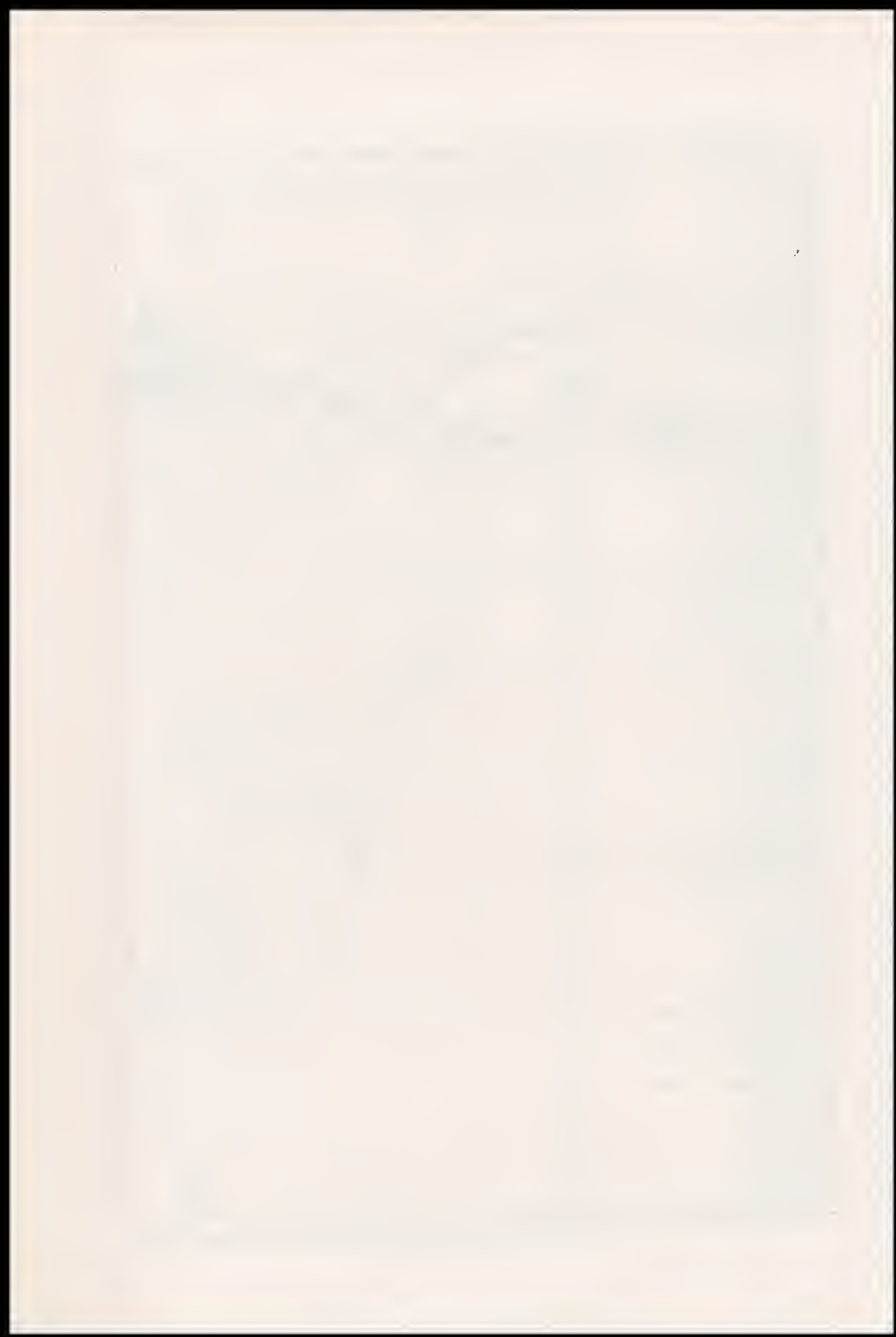

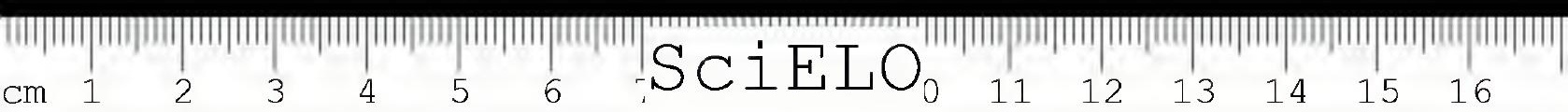


Coité, SC-24, 39-12a). The voyage was made under severe conditions of drought. In the burning 'caatingas' water was a most difficult thing to find. What little supply they had, had to be carefully transported in rubberbags. Many villages had been abandonned by their inhabitants. When the naturalists arrived in Coité, almost 30 persons were surrounding a scantily flowing spring in some rocks, waiting to obtain some water. Men armed with guns kept order. When Martius asked for some water, the only thing he obtained was an angry answer - "This water here is only for us, not for wandering Englishmen". Martius was forced to buy a little water from a soldier, who advised him that he should leave that place with all his party, and so he did, going to a farm, where a providential rain saved the naturalists.

Proceeding with many sacrifices through Santo Antônio das Queimadas (Queimadas, SC-24, 40-11b; which they left on 8 March 1819). Vila Nova da Rainha or Jacobina Nova (Jacobina, SC-24, 41-11d), food became very scarce, and had to be acquired at exorbitant prices, due to the severe drought. In Jacobina the situation was slightly better, and there they stayed, going to Monte Santo (SC-24, 39-10c) to investigate a meteorite which had fallen on the rivulet Bendego (this meteorite is now at the Museu Nacional do Rio de Janeiro), and the fossils which existed in that area. On 25 March they returned to Jacobina.

Leaving the latter city, after 4 days of marching, they arrived in Joazeiro (SC-24,41-9d), on the north of the Province, at the banks of the Rio São Francisco, on the frontier with Pernambuco, where finally they found abundant water.

Crossing the Province of Pernambuco, they entered the Province of Piaui, and following the Rio Caninde., arrived in Oeiras (SB-23,42-7c), then the capital of that province, on 3 May 1819. After some days of rest, they left on the 1lth, and on the 15th arrived in São Gonçalo do Amarante (Amarante, SB-23, 43-6d). In the next days of travel. Martius was attacked by a violent fever. His condition was very bad, and Spix remained faithfully at $h$ is side, helping with what remedies he could apply. Spix, on his turn. when he took a bath in a shallow pond, contracted a malady of the skin, and his body was covered with small ulcerating tumors (probably he contracted a schistosomiasis, of which he died in 1826). Proceeding with incredible difficulties, they crossed the Rio Paraiba, entering the Province of Maranhão, and finally arrived in Caxias (SB-23, 43-5a), where they remained until 3 June 1819 . to recuperate from the sickness and privations.

Of further relief to the naturalists was the fact that here ended their voyage by land. Embarking on the Rio Itapicurn 
(SB-23, 43-5a, 44-5d), they reached the capital, São Luis (SA$-23,44-3 a)$. There they were received by the English Consul, Robert Hesketh, and in his company made some excursions on the Island of São Luis, as well as to the nearby city of Alcântara. In São Luis they heard of the death of von Neveu, who had helped them in all their previous trips, but at the same time received a piece of good news - they had been permitted to investigate the Province of Grão-Pará, their great dream. Finally they could study the Amazonian forest.

Knowing that a Portuguese brig, the 'Prontidão' was ready to proceed to Belém they left São Luis on $20 \mathrm{July,} \mathrm{and} \mathrm{reached}$ the capital of the Province of Grão-Pará on 25 July 1819.

In Belém (SA-22, 49-1d), the two naturalists collected in several places, and went to the Rio Guamá (near Belém). On 21 August they decided to proceed up the River Amazonas.

Entering the Rio Moju (SA-22, 49-2d), they arrived at the Tocantins River, in front of the city of Cameta (SA-22, 50-2d). Going up the Tocantins, they entered the Furo do Japim and reached Breves (SA-22, 50-2a), in the south of the Island of Marajo. Proceeding by the Canal do Tajapuru, on 9 September they were in Gurupa (SA-22, 52-1d), and on the following day in Pôrto de Moz (SA-22, 52-2a), on the Xingu River.

Narigating along the right bank of the Amazons, they went by Santarém (SA-21, 55-2d) (19-30 September 1819), Óbidos (SA-21, 55-2a), Vila Nova da Rainha (Parintins, SA-21, 56-3a; on the lst of October). Serpa (Itacoatiara, SA-21, 58-3c) (12 October), arriving to Barra do Rio Negro (Manaus, SA-20, $60-3 c$; SA-21, 60-3d), where they stayed from 22 October to 2 November 1819.

Passing by Manacapuru (SA-20, 61-3d), Codajás (SA-20, 62-4a), and Coari (SB-20, 63-4c; 16 November), all localities on the Amazon River, the naturalists reached Ega (Tefé, SA-20, $65-3 d$ ) on 26 November. They decided then to follow different routes, in order to better explore the region.

Spix left Ega on 7 December 1819, ascending the Rio Solimōes, by Fonte Boa (SA-19, 66-3a), Tonantins (SA-19, 68-3b). Sāo Paulo de Olivença (SA-19, 64-4b), and arriving in Tabatinga (SB-19,70-4d), on the border between Brazil and Peru. From Tabatinga he returned to Manaus, where he arrived on 3 February 1820. Leaving again, he went up the Rio Negro to Moura (SA-20,62-1d) and Barcelos (SA-20, 63-1a), the ancient capital of the Province of São José do Rio Negro (now State of Amazonas), whence he returned to Manaus, arriving on 26 February. 
Martius, leaving Ega on 12 December, ascended the Rio Japura (SA-20, 65-2c; SA-19,69-2b, 66-2a), to the border of Brazil, and returned to Manaus on 11 March.

In Manaus, Spix and Martius received news from Belém, that a Brazilian fleet was leaving for Lisbon, and that they should go immediately to Belëm.

They left Manaus, descending the Amazons to the mouth of the Rio Madeira, and entering the latter, passed south of the Island of Tupinambarana $(\mathrm{SA}-21,58-3 \mathrm{~b})$, reaching Parintins. Proceeding by Óbidos, Santarém, Almeirim (SA-22, 53-2b), Gurupá, and Breves, they finally arrived in Belem on 16 April 1820.

After arranging all the collections, they took the ship "Nova Amazona", and on 13 June 1820 embarked for Europe.

Their stay in Brazil lasted for 2 years and 11 months. Their collections, sent to Munich, via Hamburg, consisted of 3,381 species of animals, thus distributed: 85 species of mammals, 350 of birds, 130 of reptiles (including amphibians), 116 of fishes, 1,800 of Coleoptera, 120 of Orthoptera, 30 of Neuroptera (in the old sense), 120 of Hymenoptera, 120 of Lepidoptera, 250 of Hemiptera, 100 of Diptera, 80 of Arachnida, and about the same amount of crustaceans.

Of plants, Martius collected 6,500 species, which formed the basis of the gigantic work "Flora Brasiliensis", on which almost every botanist worked, until the beginning of this century, and which was financed by five emperors, including that of Brazil, Dom Pedro II (Garcia, 1922; Hoehne, 1942; Sommer, 1954; Spix E Martius, 1823, 1828, 1831; Urban, 1908).

Let us return now to the other voyages undertaken by $\mathrm{F}$. Sellow, before following the expeditions of the last member of the Austrian commission, Johann Natterer, and the travels of P. W. Lund.

\section{Sellow's journeys in the interior of Brazil}

After the receipt of the letter of von Altenstein. Sellow returned to Rio de janeiro in July 1818. Two years before, in the company of the Prussian Consul, Count von Flemming, another naturalist had arrived - IgNaz Franz Werner Maria Von Olfers (born in Münster, Westphalia), who had studied natural history and languages at the University of Göttingen from 1812 to 1815 . Desirous of studying Brazilian nature, he joined the Legation of Prussia, as secretary to Count von Flemming. 
Upon his return to Rio, Sellow met von Olfers, and both planned a trip to some provinces of Brazil, financed by Count von Flemming. On 10 August 1818, all the equipment was ready; Sellow was in charge of the plants, while Olfers would collect insects and geological samples. Leaving Rio de Janeiro, they crossed the Serra dos Orgãos, and on 3 September passed the Rio Paraibuna (SF-23, 44-22b), entering the Province of Minas Gerais. Then they headed for Barbacena (SF-24, 44-21b). Ouro Branco (SF-23, 44-20d), Vila Rica (Ouro Prêto, SF-23, 44-20d) (23 September - 2 October). Itambé do Mato de Dentro (SE-23, 43-19c) (9 October), Serra de Santo Antônio (?) (17 October). Ribeirão do Galheiro (SE-23, 44-18d) (20 October). Serra do Vento (?) (22 October). Serra da Meada (?) (26 December). and Itabira (SE-23, 43-20a) (27 December). In 1819 they went by Serra da Cachoeira (10 January). Serra de Itacolomi (SE-24, 44-19d) (20 January and again on 10 May), arriving at the Serra da Piedade (SE-23, 45-18b) on the 30th of March, visiting the Serra do Caraça on 2 April, and returned afterwards to Vila Rica.

Leaving Vila Rica on 20 April 1819, they proceeded to São João del Rei (SF-23, 44-21c), entered the Province of São Paulo, passing by Jundiai (SF-23, 47-23d) and Itu (SF-23, 47-23c), and arrived in the City of São Paulo (SF-23, 47-24b) at the end of the month. From Sāo Paulo they went to Ipanema (presently Varnhagen), where they were received by the director of the iron forges, Varnhagen. There they met Natterer.

From Ipanema Olfers returned to Sāo Paulo, proceeded to Santos, and embarked for Rio. There he sent his collection to the Museums of Vienna and Berlin. Sellow remained in Ipanema for a while and then went to São Paulo, making an excursion to the Serra de Paranapiacaba (SF-23, 46-24a; now a biological station belonging to the Instituto de Botânica da Secretaria da Agricultura de Sāo Paulo), and went also to Ribeira do Iguape (SG-23, 47-25a; SG-23, 48-24d), where he worked during the month of October. The two following months he remained in Ipanema, which he left on 7 January 1820, going to the city of São Paulo, where he stayed from 12 January to 8 February. He proceeded then to Santos (SF-23, 46-24a), working there until 11 April, visited the Island of São Sebastitão (SF-23, 45-24a). and, going up the coast, arrived to Angra dos Reis (the ancient Vila da Ilha Grande, as was called in that period. SF-23, 44-23a).

Back in Rio, where he arrived on 9 May, Sellow had alieady. spent 6,500 marks. With Olfers he made a new plan to explore 
the southern provinces of Brazil, going afterwards to Mato Grosso, and then, down the Amazon River, to Pará. The plan was submitted to von Altenstein, who gave them a grant of 12,000 marks. On 16 April 1820. Dom João VI had granted Sellow an annual pension of $600 \$ 000$ (600,000 réis). "for voyages and philosophical observations in several parts of Brazil". with the condition that duplicates should be deposited in the National Museum of Rio de Janeiro, Olfers, however, gave up the idea of joining the expedition, and Sellow decided to travel alone.

Before going on to Uruguay, as he had planned, Sellow sent four shipments of collections to the Berliner Zoologischer Museum. The first was sent on 21 May 1820, and included the collections made in the trip from Rio to Minas Gerais, Minas Gerais to São Paulo and São Paulo to Rio (10 August 1818 to 9 May 1820); this first shipment arrived to Berlin on 8 November 1820 . The second was sent on 20 July 1820, arriving on 27 November 1820. The third and fourth collections were envoyed on 18 February 1821, and reached the Zoologisches Museum on 4 and 13 August 1821, respectively. The plants, birds, and mammals contained in those collections were mainly collected by Sellow, while Olfers took care of insects, fishes, amphibians, reptiles, helminths (later studied by Rudolphi), and geological samples.

Early in November 1821, Sellow sailed from Rio de Janeiro to Montevideo, arriving there after 18 days of voyage. He collected in the neighborhood of that city, and then, ascending the Rio Santa Lucia (SI-22, 35-56a; between the Provinces of San José and Canelones) up to its sources, proceeded to the Rio Cebollati (SI-22, 33-54d); then, passing by Minas (Lavalleja Province, SI-22, 34-55c). San Carlos (Maldonado Province, SI-22. $35-55 b$ ) and Maldonado (SI-21,35-55b), returned to Montevideo.

From the Capital he sent, in the end of September 1822, 3 boxes with mineral samples, 1 with 700 species of plants (each plant represented by 4 or 7 specimens), 1 with seeds and living plants, 4 boxes and 1 barrel containing a total of 2.300 specimens of insects, some mammals, 230 specimens of birds (representing 116 different species), 20 species of fishes, several snakes, intestinal worms, and several anatomical preparatitons, preserved in alcohol, for the collection of anatomy of the Berliner Museum. These collections represented the results of his voyages from Montevideo to the Rio Cebollati and back to Montevideo, from 2 January to July 1822. The collections were received in Berlin on 16 May 1823. To the Museums of Rio de Janeiro and Lisbon 9 boxes with duplicates were shipped. 
In November 1822, Sellow started a new trip, going from Montevideo to Colonia del Sacramento (Colonia Province, SI-21, 34-58d). Crossing the Rio de La Plata, he visited Buenos Aires (SI-21, 35-58a), and, returning to Colonia del Sacramento, proceeded along the left bank of the Rio Uruguay, passing by Conchillas (SI-21, 34-58c). Carmelo (SI-21, 34-58c). Nueva Palmira (SI-21, 24-58a) (all in the Province of Colonia). Dolores (SI-21, 34-58a), Mercedes (Soriano Province, SI-21, 33-58c; 19 December 1822 to 7 January 1823). Haedo (SI-21, 33-58b). Bellaco (SI-21, 33-58b) (both in the Province of Rio Negro). Paysandú (SI-21, 32-58c). Constancia (SI-21, 32-58c). Queguay (SI-21, 32-58d). Quebracho (SH-21, 32-58b), Pda. Guaviyú (SH-21, 32-58b). Pda. Rivas (SH-21, 32-58b), Chapicuy (SH$-21,32-58 b)$. Dayman (SH-21, 32-58b) (all in the Province of Paysandui), finally arrived in the city of Salto (Salto Province. SH-21, 31-58d), where he remained from 21 February to 7 March 1823. Travelling in the western part of the Province of Salto, he reached the city of Tacuarembo (Tacuarembó Province, SH-21, 32-56a), and then, crossing the Province of Rivera in a northward direction, reached the city of Rivera (SH-21, 56-31b). and entered again the Brazilian Province of São Pedro do Rio Grande do Sul, in the city of Livramento (SH-21, 56-31b), close to Rivera.

His route took him through the arroios (creeks) of Vacaqua (SH-21, 55-30c), the city of Rosário do Sul (SH-21, 55-20d). Banhado do Inhatium (SH-21, 55-30d). São Gabriel (SH-21, 54-30c). Arroio Igá (SH-21, 54-30c), Arroio Ibiajutura (SH-22. 54-30c). Caçapava do Sul (SH-22, 53-30d). Arroios Capanèzinho and Capane (SH-22,53-30d), and arriving at the banks of the Rio Jacui, he followed the course of that river to the city of Rio Pardo (SH-22, 52-30a). going on then to Taquari (SH-22, $52-30 \mathrm{~b})$, and reaching the city of Pôrto Alegre (SH-22, 51-30c) in May 1823.

From Pôrto Alegre Sellow shipped, on 18 August 1823, the collections gathered on the itinerary Montevideo-Colonia-Salto-Sāo Gabriel-Pôrto Alegre (6 November 1822 to 14 May 1823). these having reached the Museum of Berlin on 15 May 1824.

Once the collections were sent. Sellow started a new journey through Rio Grande do Sul. Leaving Pörto Alegre, he followed the Rio Jacui to the city of Cachoeira do Sul (SH-22, 53-30d), and proceeded to Arroio Acangupá (SH-22, 53-30c). Arroio São Sepé (SH-22, 53-30c). Caçapava do Sul (SH-22, 53-30d: where he stayed for a while, studying the gold mines of the Serra de 
Caçapava: "Kassapawa im Innern von Brasilien" of Wiedemann). Arroio Irapuã (SH-22, 53-30c), Rio Camaquã (SH-22, 54-31b). Arroio das Palmas (SH-22, 54-31d). Arroio do Tigre (SH-22, $54-31 \mathrm{~d})$, and Bagé (SH-22, 54-31c). From the city of Bagé he entered the Rio Negro (SH-21, 55-32b), which he navigated, entering a second time into Uruguay, as far as the Sierra de Aceguá (Cerro Largo Province, SH-21, 32-54a), whence he returned to Rio Grande do Sul after crossing the Rio Jaguarão (SH-22. 54-32b). Proceeding then past Erval (SH-22, 53-32a). Arroio Basilio (SH-22, 53-32b), Piratininzinho (SH-22, 53-32a). Piratini (SH-22, 53-32a). Arroio Solidão (SH-22, 53-31d), Arroio Saraiva (SH-22, 53-32b), and Arroio Pelotas (SH-22, 52-32a). he reached the city of Pelotas (SH-22, 52-32a). In the city, on 6 June 1824, during the flood of the Arroio Pelotas. he lost a box with dried plants, one with skeletons, and part of his insect collections. This would be the first of a series of unfortunate occurrences. Continuing his trip, he crossed the Canal de São Gonçalo (SH-22, 52-32a), and passed by the southern limit of the Lagoa dos Patos, reaching the city of Rio Grande in July 1824. While passing by the Lagoa dos Patos, he had a fall from his horse, which resulted into a fracture of the clavicle.

After his recovery. Sellow sent to Berlin two shipments of the collections obtained in the itinerary Pôrto Alegre-Caçapava- Bagé-Rio Grande (during the period of 29 August 1823 to July 1824 ), both in different days of November 1824. The first shipment was lost in a shipwrech near Helgoland. The second arrived safely to Berlin, on 1 July 1825. Leaving the city of Rio Grande on 31 December 1824. Sellow sailed through the Lagoa dos Patos (SH-22, 51-31a), arriving to Porto Alegre (SH-22. $51-30$ c) on 9 January 1825.

Sellow then made a decision to proceed on a more extensive trip, this time visiting the Province of Missones (now the western part of the State of Rio Grande do Sul). Leaving Pôrto Alegre on 17 February 1825, he crossed the Arroios dos Ratos (SH-22, 52-30d). Francisquinho (SH-22, 52-30c), and Itaticui-Mirim (SH-22, 52-30c), reaching the city of Encruzilhada do Sul (SH-22, 53-31b). From there, crossing the Arroio Capanezinho $(\mathrm{SH}-22,53-30 \mathrm{~d})$, the Rio Irapuã $(\mathrm{SH}-22,53-30 \mathrm{c})$, he visited again Caçapava do Sul (SH-22, 53-30d). Going on via Arroio São Sepé (SH-22, 53-30c). Arroio Ibiajutura (SH-22, 53-30c). Arroio Igá (SH-21,54-30d). São Gabriel (SH-21, 54-30c), Banhado do Inhatium (SH-21, 55-30d), Rosário do Sul (SH-21. 55-30d), he crossed the Arroios Vacaquá (SH-21, 56-31b), Ibi- 
rapuitã-Chico (SH-21, 56-30d). Ibirapuitã (SH-21, 56-30d), Sarandi (SH-21, 56-31a), and Quarai (SH-21, 56-30c), entering Uruguay for the third time.

Exactly at that place, the Brazilian and Uruguayan troops were fighting. The Provincia Cisplatina (nowadays the Republic of Uruguay, at that time a province of the Brazilian Empire) wanted its independence. The fight would end only in 1828, resulting in the autonomy of Uruguay. Thanks to the Brazilian Commander Bento Manuel Ribeiro, Sellow traversed the battle field without trouble, and through the Province of Artigas, reached the city of Belén (Salto Province, SH-21, 31-58b), on the banks of the Uruguay River, in the middle of January 1826.

Leaving Belén, Sellow returned to Rio Grande do Sul, which he entered after crossing the Arroio Quarai (SH-21, 56-30c). Continuing his journey, he passed through the area between the Arroios Aval and Cati (SH-21,56-30c), and crossing the Arroio Pai Passo (SH-21,56-30d), reached the city of Alegrete (SH-21. 56-30b) (May, 1926). From Alegrete he wrote on 18 April 1826 to the President of the Province of Rio Grande do Sul about the discovery he had made of a giant fossil (Megatherium), found near the Rio Arapei in Uruguay, and asked the President to send his boxes with collections to the National Museum of Rio de Janeiro (see Appendix II). Following the course of the Rio Ibirapuitã (SH-21,56-30b) to its mouth in the Rio Ibicui (SH-21, 56-29c), he arrived in São Borja (SH-21, 56-29b), near the margins of the Uruguay River. Proceeding through the Missões, he crossed the Rio Icamaqua (SH-21.56-29b), the Arroio do Urucutai (SH-21, 56-28d), and the Rio Piratini (SH-21. $55-28 c$ ). and went on to São Luis Gonzaga (SH-21.55-2Sd) and São Miguel das Missões (SH-21, 55-29b). Crossing the Ijui and Ijuizinho Rivers (SH-21,54-28c), he went through Santo Angelo (SH-21, 54-28c), Cruz Alta (SH-22, 54-29b), Cruz Altinha (SH-22, 52-28d), Muliterno ( $\mathrm{SH}-22,52-28 \mathrm{~d}$ ), arriving at the banks of the Rio Pelotas (SH-22, 51-28d) at the border between Rio Grande do Sul and Santa Catarina. Returning and heading south, he crossed the Rio Carnciro (SH-22, 52-28d), passed through the city of Guapore (SH-22, 52-29b), and finally arrived at Pôrto Alegre (SH-22, 51-30c), on 10 November 1826.

The collections obtained on this long journey (from 9 June 1825 to 10 November 1826), were sent from Pôrto Alegre in November 1826, and arrived at the Museum of Berlin on 14 May 1827. However, only a part of those collections could be shipped. The Brazilian Emperor had come to Pôrto Alegre in order to su- 


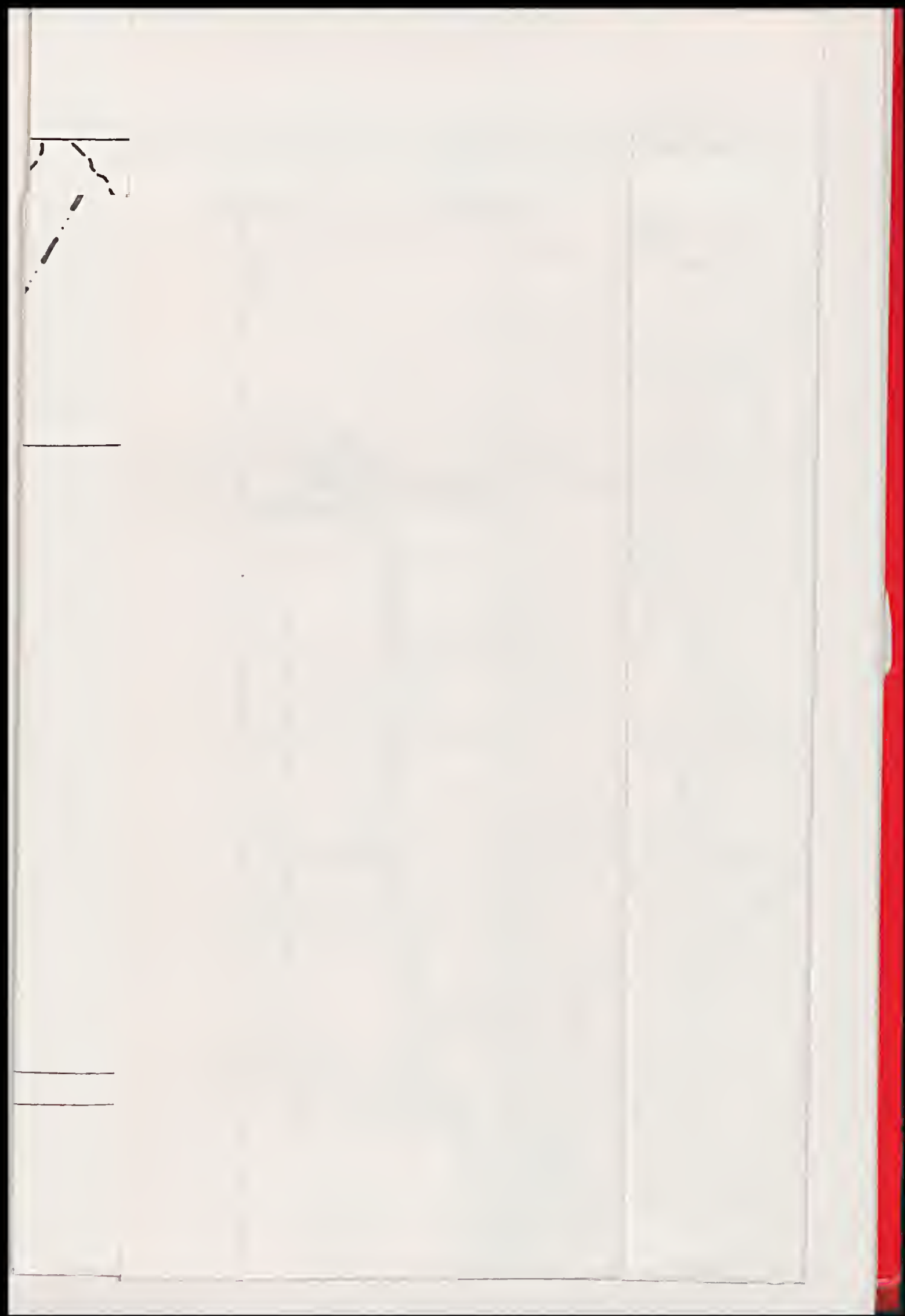




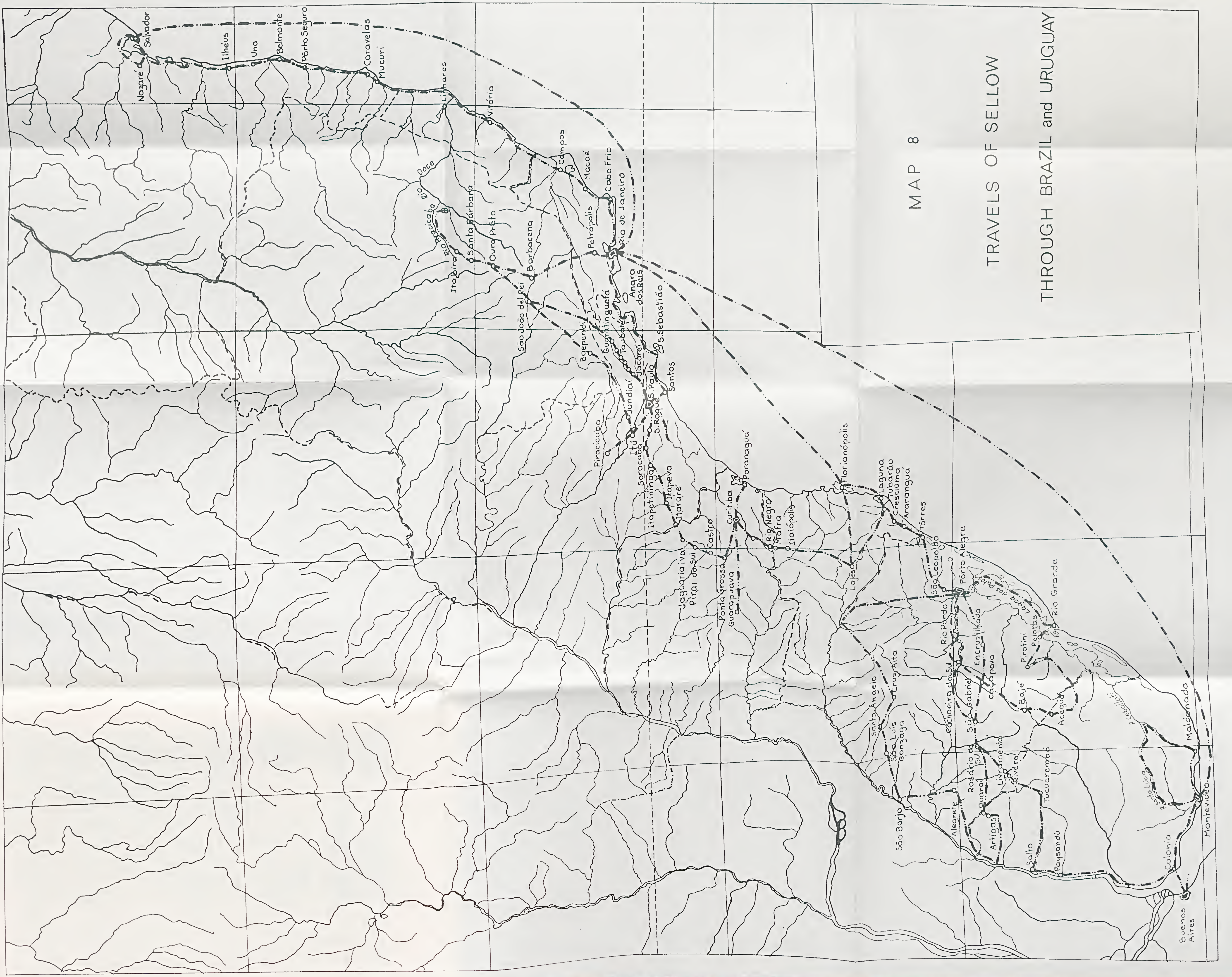




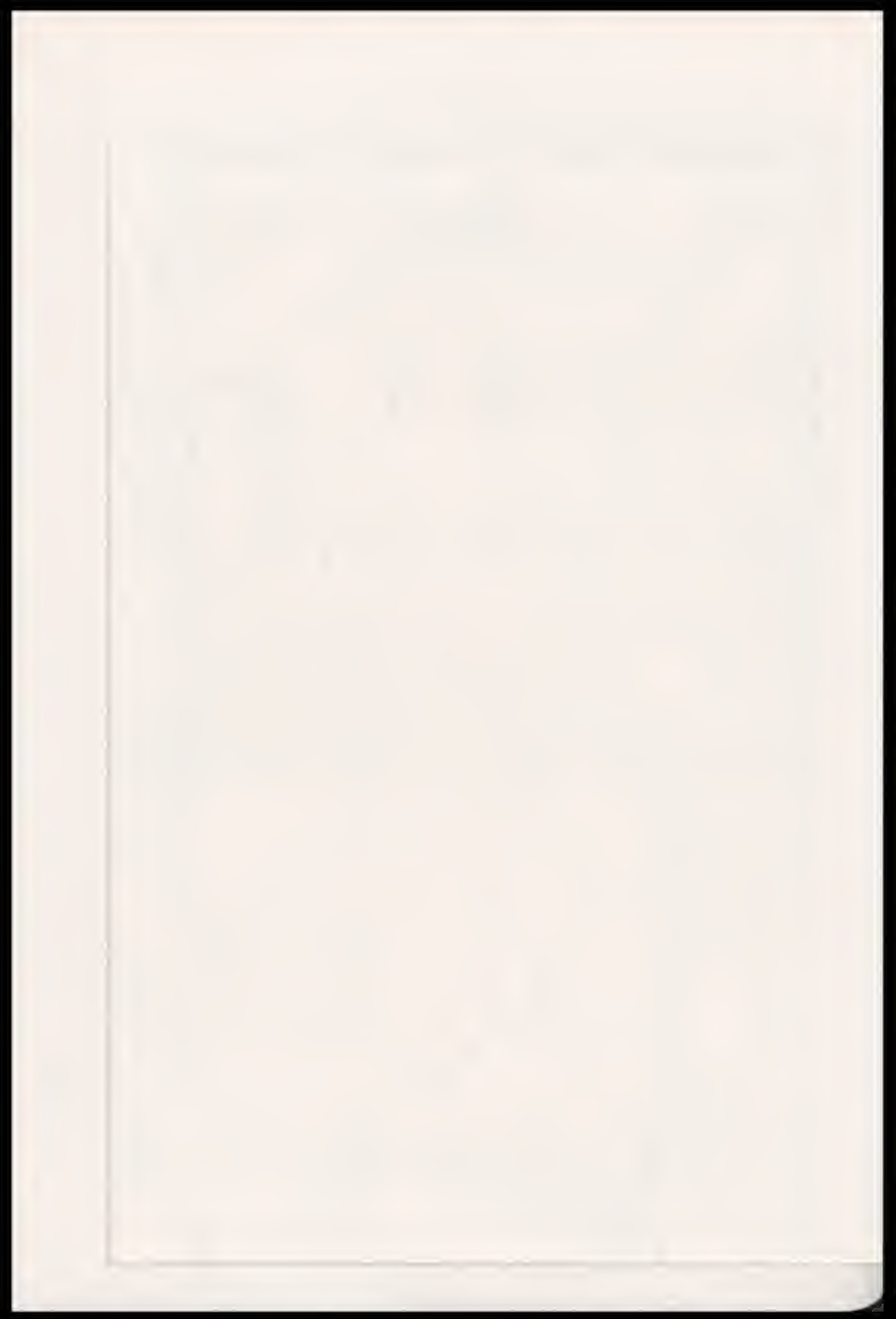

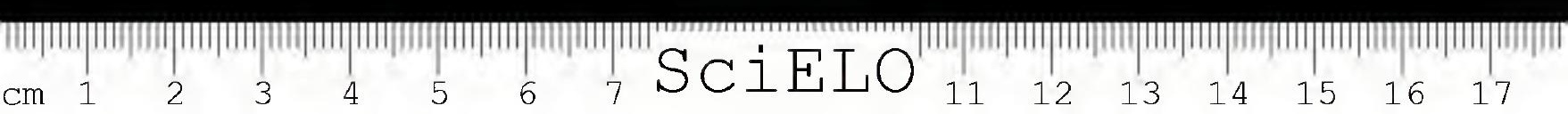


pervise the campaign against the Uruguayan rebels, and, meeting Sellow, who was also employed by the Brazilian National Museum of Rio de Janeiro as collecting naturalist, asked him to go after interesting minerals in the mines of Caçapava. The Emperor wished to present those minerals to his wife, the Empress Leopoldina.

Leaving Pôrto Alegre on 9 January 1826, Sellow followed the Rio Jacui to the city of Rio Pardo (SH-22, 52-30a), and from there, overland, following a northwesterly direction, headed to Candelária (SH-22, 53-30b). Sobradinho (SH-22, 53-29d). and Cachoeira do Sul (SH-22, 53-30d). Crossing the Rio Vacacai (SH-22, 53-30a), and again following the Rio Jacui (SH-22, 53-30a). for a distance, again in a northwesterly direction, reached a point near the village of Taquarembó (SH-22, 54-29d) and São Martinho (SH-22, 54-30b). Proceeding by Santa Maria (SH-22, 54-30b), after crossing the Arroio Tambaquaré (SH-22. 54-30b), the Banhado Santa Catarina (SH-22, 54-30b), and the Rio Vacacai (SH-21,54-30c), he arrived in the city of São Gabriel (SH-21, 54-30c). After crossing the Rio Camaqua-Chico (SH-21, 54-31c). Sellow reached Caçapava do Sul (SH-22. 53-30d), and passing by Encruzilhada do Sul (SH-22, 53-31b), returned to Pôrto Alegre (SH-22, 51-30c).

The Emperor, however, had returned to Rio de Janeiro after receiving the sad news of the death of the Empress Leopoldina. Sellow had not wasted his time on that trip, in spite of all. He brought back new collections of natural history. which. with the remaining specimens of his penultimate trip (through the Missôes). were sent from Pôrto Alegre in April 1827, arriving to Berlin in October of that same year. This was probably the last collection of Sellow which Wiedemann was able to study, since the other shipments (see Table I), sent by Sellow at later dates, reached the Museum of Berlin in 1829 (Wiedemann's first volume of the "Aussereuropäische zweiflügelige Insekten" had already been published), and 1831 (after the second volume was published).

After those prolonged trips. Sellow missed the companionship of his fellow countrymen, and decided to go to São Leopoldo. north of Porto Alegre, where a florishing German colony had begun to grow. There he had a well deserved rest.

Leaving São Leopoldo (SH-22, 51-30a) on 3 April 1827, he headed to the east. arriving at Santo Antônio da Patrulha (Santo Antonio, SH-22,51-29-a), and went on to the north, entering the Province of Santa Catarina. Passing by Araranguá (SH-22. 
49-29a), Criciúma (SH-22, 49-29a), Jaguaruna (SH-22, 49-29a), and Tubarão (SH-22, 49-28c), he reached the city of Laguna (SH-22, 49-28d), on the coast of Santa Catarina. Passing again by Tubarão, he then went on to Lajes (SH-22, 50-28a). in the interior of the Province, remaining there for some time. His pack of mules, which had had no rest since his departure from Montevideo, were left there, witht the objects not necessary to his next trip to Rio de Janeiro. While his mules rested. Sellow went to the capital of the Province. Florianópolis (SG-22, 48-28a), whence he embarked in July 1827. for Rio de Janeiro, carrying his collections. In the same month he arrived in that city and sent his specimens to the Berlin Museum, where they arrived in 24 December 1829. After spending about two months in the capital, Sellow decided to return to Santa Catarina, making use of the opportunity presented by Captain P. King, who, aboard the ships 'Adventure' and 'Beagle' was sailing for Florianópolis on his way to Cape Horn. Sellow landed in Florianopolis, sailed to Laguna, and went overland to Lajes.

After staying in Lajes from 31 January to 6 March 1828. he left for the north, through Taio (SG-22, 50-27d). Itaiopolis (SG-22, 50-26d), and Mafra (SG-22, 50-26d), and entered the Comarca de Curitiba (presently the State of Paraná) at the city of Rio Negro (SG-22. 50-26d). Passing Lapa (9 April: SG-22. 50-26b). Contenda (SG-22, 50-26b). Araucária (SG-22, 49-26a). he reached the city of Curitiba (SG-22, 49-25c). From Curitiba. going down the Serra do Mar, he visited Paranaguá (SG-22. 48-26a), and returned to Curitiba. Proceeding then to the west. he went to investigate the "campos" (grasslands) of the region of Guarapuava (SG-22, 51-25c). spending there the months of September. October, and November of 1828 . Returning again to Curitiba. he followed by Ponta Grossa (SG-22, 50-25d. 50-25c). Castro (SG-22, 50-25a). Pirai do Sul (SG-22, 50-25b). and Jaquariaiva (SG-22,50-24d) to the Province of São Paulo, which he entered at Itarare (SF-22. 49-24b). Through Itapeva (SF-22, 49-24b). Itapetininga (SF-22, 48-22a). Sorocaba (SF-23. 47-24a). São Roque (SF-23, 47-24a) and Cotia (SF-23, 47-24a). he arrived in the city of São Paulo (SF-23. 47-24b) on 25 March 1829. staying there until May 1830. not only to restablish his health, but also to put some order into his collections.

Meanwhile, he made several excursions. to the Pico do Jaragua (now in the outskirts of the city of São Paulo) and also Constituiçāo (presently Piracicaba. SF-23,48-23b). down the Serra do Mar to Santos (SF-23,46-24a), visiting the Ilha da 
Moela (SG-23, 46-24c). On those trips he obtained interesting zoological, botanical, and mineralogical specimens.

Sellow's plan was then to go on to Paraguay, via the rivers Tietê, Paraná, and Paraguay. However, two events made the plan unfeasible - the Jesuits forbade the entrance of anyone into Paraguay, and news reached Sellow that Bonpland had been arrested by the dictator of that country, some people even saying that the naturalist had been shot. Sellow decided then to go through Minas Gerais. Goiás, and Mato Grosso to reach the Amazons.

Sellow started from Sāo Paulo on 23 May 1830, taking the road to Rio de Janeiro, to the village of Guaratinguetá (SF-23, 45-23a). From there he sent to Rio on 20 June 1830 the coliections obtained in his trip from Florianópolis to Lajes. Curitiba. and São Paulo. These collections reached the Museum of Berlin on 29 June 1831. Crossing the Serra da Mantiqueira, he entered the Province of Minas Gerais, going to Itajubá (SF-23. 45-22c) and São João del Rei (SF-23, 44-21c). where he arrired in August. In Norember he reached the city of Ouro Prêto ( $S F-23,44-20 d)$. where he found with great pleasure a fascicle of the monumental botanical work which was being edited by Martius - the 'Flora Brasiliensis'. Sellow remained in that city for some time, collecting in the neighborhood. going to the Serra do Caraça (Municipio de Santa Barbara, SF-23, 43-20a), in the second half of December, and making the preparations for his intended trip to the north of the Empire. On 18 February 1831. he sent to Lichtenstein the last collection, including the specimes gathered between São Paulo and Ouro Prêto (fron 30 May 1830 to 18 February 1831): this collection arrived to Berlin on 13 December 1831.

In Ouro Prêto he made his last will (which is here published as Appendix. III to this chapter). with provisions concerning the destiny of the scientific collections and instruments. freeing his slave, and disposing of the money and equipment; he received the last 3.500 marks owned him by the Brazilian Government, and left the city on 29 March 1831.

Sellow went through Congonhas (SF-23, 44-20d). Paraopeba (SE-23, 44-20c). Serra de Itabira (SE-23, 43-20c; 12 May 1831). Cocais, and Antonio Dias (SE-23, 43-20b). on the banks of the Rio Piracicaba. which he followed to its confluence with the Rio Doce. While bathing in the Rio Doce, he drowned, on an unascertained day of November 1831, at little more than 42 years of age. Was it suicide? Why should Sellow have made 
his last will in Ouro Prêto before leaving on this trip? After 17 years of experience in Brazil, he would have no fear of the dangers of an expedition to the northern provinces. His death is surrounded by mystery.

The last collections obtained by Sellow, together with his scientific instruments and personal papers, were transported by his servants to Rio de Janeiro and delivered to his old friend and colleague Olfers.

Olfers kept everything with him. Leaving Brazil in 1836. as Prussian commercial agent in Berne. Switzerland, he still retained Sellow's materials, comprising a big trunk with manuscripts, 12 boxes with plants retained by Sellow for his own use, ten boxes of natural history objects, books, and instruments, all of which were thus rendered useless to science. Soon afterward. Olfers was named general director of the Museum of Arts in Germany, and had no time or interest to dispose of the collections. Several years passed before the last collections organized by Sellow found their way to the Museum. Olfers saved, however. all the manuscripts, which were given to the Royal Museum of Botany of Berlin only after his death in 1872 .

In the above-mentioned trunk which remained for such a long time in Olfers' possession were found:

1. Sellow's notes regarding the numbers of the plants in the herbarium.

2. Sellow's correspondence, bills, letters of recommendation and presentation granted by the Brazilian authorities, his correspondence with the Prussian Minister of Culture, and his last will.

3. Extensive journals of his journeys, which unfortunately have never been published (containing. however. limited information on the botanical and zoological specimens collected).

4. Several astronomical and meteorological observations.

5. Astronomical determinations of several localities and cities.

6. Glossaries of the dialects of several Indian tribes among which Sellow stayed during his voyages, such as the Minuano and Charrua of Rio Grande do Sul, who were already nearing extinction at the time, and of the Parana or Cojopó Indians of Guarapuava, in the State of Parana., and some tribes of southern Bahia. 
7. Common names of many plants.

8. List of the plants collected in southern Brazil in the years 1823-1829.

9. Many diagnoses of new species of plants, which later were partially used by Klotzsch (Hoehne, 1942).

A number of sketches, prepared by Sellow, not only of plants, but also of landscapes and Indians, were also included. Of these, 12 drawings were made in his trip from Rio de Janeiro to Bahia, 56 in the States of Minas Gerais and São Paulo; 135 on his trip to Montevideo, and from there to Minas Gerais. Only three of these drawings have been published, namely, the aspect of the coast of Taberuçu, of Pôrto-Seguro, and of Ilhéus (all three localities in Bahia), in the book of travels of Prince Maximilian $z u$ Wied-Newied (plates 15, 16, and 18, respectively).

Sellow's collections of zoology, organized from 1817 to 1813 and deposited in the Berliner Zoologisches Museum, were one of the most valuable ever gathered by a naturalist. They comprised 263 mammal and 5.457 bird skins, more than 100,000 specimens of insects, nests and eggs of birds, skeletons. a number of molluscs, anatomical preparations preserved in alcohol, several helmints, etc. He also collected 12,500 specimens of plants, which were studied by several authors in the 'Flora Brasiliensis' of Martius, 1,698 different seeds, over 2,000 geological samples, and many ethnographic artifacts.

The Diptera portion of his collection was studied by Wiedemann, and was the basic collection which served for his 'Aussereuropäische zweiflügelige Insekten". Unfortunately, Wiedemann does not mention the specific locality, but this is mentioned on some of the labels (Fairchild, 1967).

The National Museum of Lisbon also received specimens from Sellow, but only those which were duplicates of the materials obtained until 1822. Of the materials collected by Sellow for the National Museum of Rio de Janeiro, nothing is left. I have seen in the archives of the National Museum a number of letters of the Director of the "Alfandega" of Rio de Janeiro (Customs Director) to the various directors of the National Museum. telling of the arrival of the several collections sent by Sellow to Rio de Janeiro. But no zoological specimen collected by Sellow exists in the collection nowadays. Of the plants given by him to the Museum, part was taken away by Gaudichaud- 
-Beaupré (see Chapter IX), the rest having been eaten by museum pests or left unstudied.

Sellow was to Wiedemann what Saint-Hilaire (see Chapter IX) was to Macquart. Both collected in the same areas, and most probably obtained almost similar collections (Garcia, 1922; Hoehne, 1942; Lacerda, 1905; Ladislau Netto, 1870; Stresemann, 1948: Urban, 1908).

\section{J. Natterer}

Of the naturalists who came with Archduchess Leopoldina, there remains to be mentioned Natterer and Kamerlacher. JoHANN NATTERER was born on 9 November 1887 in Laxenburg, near Vienna. His father was 'Imperial and Royal falconeer' and a collector of birds and insects. Emperor Francis bought in 1793 the collections made by Natterer senior, who was made curator. Johann, after his first studies. frequented the lectures on chemistry. anatomy and natural history, as well as modern languages. and learned to draw with perfection. His father made him an excellent hunter and taxidermist. During the years of 1806 and 1808 Johann Natterer travelled through several countries under the domain of the Austrian Crown; in 1809 he worked at the Imperial Zoological Museum, and accompanied the collections to Hungary. during the invasion of Austria by Napoleonic troops. In 1810 he returned to Vienna. At his own expenses he travelled from 1812 to 1814 through Italy to Calabria, and worked several times on the Adriatic coast. In 1815 he was sent to Paris to help in the transportation of objects of art and scientific materials stolen during the French occupation of Austria, and profited thereby in broadening his knowledge of natural sciences. In 1818 he was named assistant of the Imperial Cabinet of $\mathrm{Na}$ tural Objects, and in 1817 he was appointed member of the scientific commission which was to go to Brazil with the Archduchess.

His journeys in Brazil can be divided as follows:

1. Journey through the present States of Guanabara and Rio de Janeiro.

Natterer left the city of Rio de Janeiro on 5 February 1818. and sailed to Sepetiba (SF-23, 44-23b). passing by Barra de Guaratiba, Pedra, and Ponta do Piai. He landed in Sepetiba on 7 February and remained there until 18 March. In the meanti- 
me, he visited from Sepetiba the Rio Itaguai (bordering the present states of Guanabara and Rio de Janeiro). on the 28th. and went to the River 'Piraquao' (Piração) and Piraqué (11-15 February). On 19 March he crossed the Bay of Sepetiba and landed on the Restinga (sand bar) de Marambaia, collecting there until the 23rd. On the 24 th he visited the Island of 'Tacuczar' (Itacurussá), and returned to Sepetiba, remaining there from 28 March to 4 May. In that period he crossed the Rio Itaguai, going to the city of Itaguai (SF-23,44-23b), and São João Marcos, both in the present State of Rio de Janeiro. Sailing from Sepetiba on 7 May, he arrived in Rio de Janeiro, where he remained until 1 November 1818.

2. Trip from Rio de Janeiro to Ipanema, in São Paulo

Leaving Rio de Janeiro on 2 November 1818. Natterer went by Santa Cruz (State of Guanabara; 4 November). Itaguai (SF-23. 44-23b). Rio das Araras (SF-23, 43-22c; 7 November). Pirai. at the margins of the Rio Pirai ( $\delta$ November) (all three localities in the present State of Rio de Janeiro), and entered the Province of São Paulo. Passing by Areias (SF-23. 45-33a) (November 15), Lorena, Guaratinguetá (SF-23, 45-23a). Aparecida (SF-23, 45-23a). Pindamonhangaba (SF-23. 46-23b). Tremembé, Taubaté (SF-23, 46-23c) (24-25 November). São José dos Campos (1 January 1819). Jacarei (SF-23, 46-23c; 1-3 January), and Mogi das Cruzes (SF-23, 46-23c; 7-8 January). Natterer reached the city of São Paulo on 12 January. remaining there until the 27th. From São Paulo (SF-23, 47-24b), he went on then via Cotia, São Roque and Sorocaba (all SF-23, 47-24a) to the iron works of Ipanema (presently Varnhagen), remaining there for a long period (2 February 1819 to 15 July 1820). On 25 March 1820, he paid a visit to the city of São Paulo.

Natterer's plan was to proceed from Ipanema to Porto Feliz, and thence. along the rivers Tietê, Paraná, Paraguay. São Lourenço, and Cuiaba, to the city of Cuiabá, in the Province of Mato Grosso. However, he was ordered by the Austrian Minister to return to Rio de Janeiro, and then to Europe. Natterer protested against the order, stating that he would rather proceed at his own expense than return to Europe. While he waited for the Minister's answer. he sent the collections gathered so far from São Paulo, which he visited on 25 March 1820 to Rio. The collections were sent to Santos, and then by ship, to Rio de Janeiro. Returning to Ipanema, Natterer decided to follow to Curitiba, while his companion Sochor, who had accompanied him on the trips, remained in Ipanema. 
3. Trip from Ipanema to Paranaguá (in the present State of Paraná).

Leaving Ipanema on 15 July 1820, Natterer proceeded through Itapetininga (SF-22, 48-22a), Itapeva (SF-22, 49-24b) (10 August to 7 September), and Itararé (SF-22, 50-24b). and entered the 'Comarca de Curitiba' (then a part of the Province of São Paulo, now the State of Paraná). Passing by Jaguariaiva (SG-22, 50-24d; 15-21 September 1820), he crossed the Rio das Cinzas (SG-22, 50-24d) (22-23 September), and passing by Castro (SG-22, 50-25a; 27 September) and Ponta Grossa (SG-22. $50-25 \mathrm{~d}, 50-25 \mathrm{c}$ ), arrived to Curitiba (SG-22, 29-25c) on \& October. There he remained until 21 December 1820, making excursions to Castro on 12 and 20 December, and to Paranaguá (SG-22. 48-26a) on 13-19 December. Leaving Curitiba definitely on 21 December, he went to Paranaguá, remaining there until 10 January 1821, when he sailed for Rio de Janeiro, arriving after a voyage of 22 days.

4. Trips in vicinity of Rio de Janeiro and second trip to Ipanema.

While waiting for a permission from the government in Vienna to stay in Brazil. Natterer explored the vicinity of the city of Rio de Janeiro from 1 February to 21 March 1821. visiting especially the Corcovado Mountain. Aboard the brigantine 'Henriquez' he sailed from Rio de Janeiro to Santos (14-16 August). proceeded up the Serra do Mar to Sāo Paulo, and went on to join Sochor in Ipanema. There they remained from 2 September 1821 to 30 September 1822.

5. Trip through the northern part of the Province of São Paulo and the Provinces of Goias and Mato Grosso, to Cuiaba.

In Ipanema Natterer finally received the permission to continue his explorations in Brazil, and the necessary funds for the trips. With Sochor he left Ipanema on 7 October 1822. and departed for the Provinces of Goiás and Mato Grosso. From Ipanema he proceeded through Sorocaba (SF-23. 47-24a). Itu (SF-23, 47-23c; 26 October). Salto (26 October to 5 November). Campinas (SF-23, 47-23a: 12 November). Rio Atibaia (SF-23. 47-23d) (16 November). Rio Jaguari (SF-23,47-23b). Mogi Mirim (SF-23, 47-22d) and Oriçanga, a small locality near Mogi Mirim (SF-23, 47-22d). where he collected from 28 November 
to Europe

| $\mathrm{cm}$ 


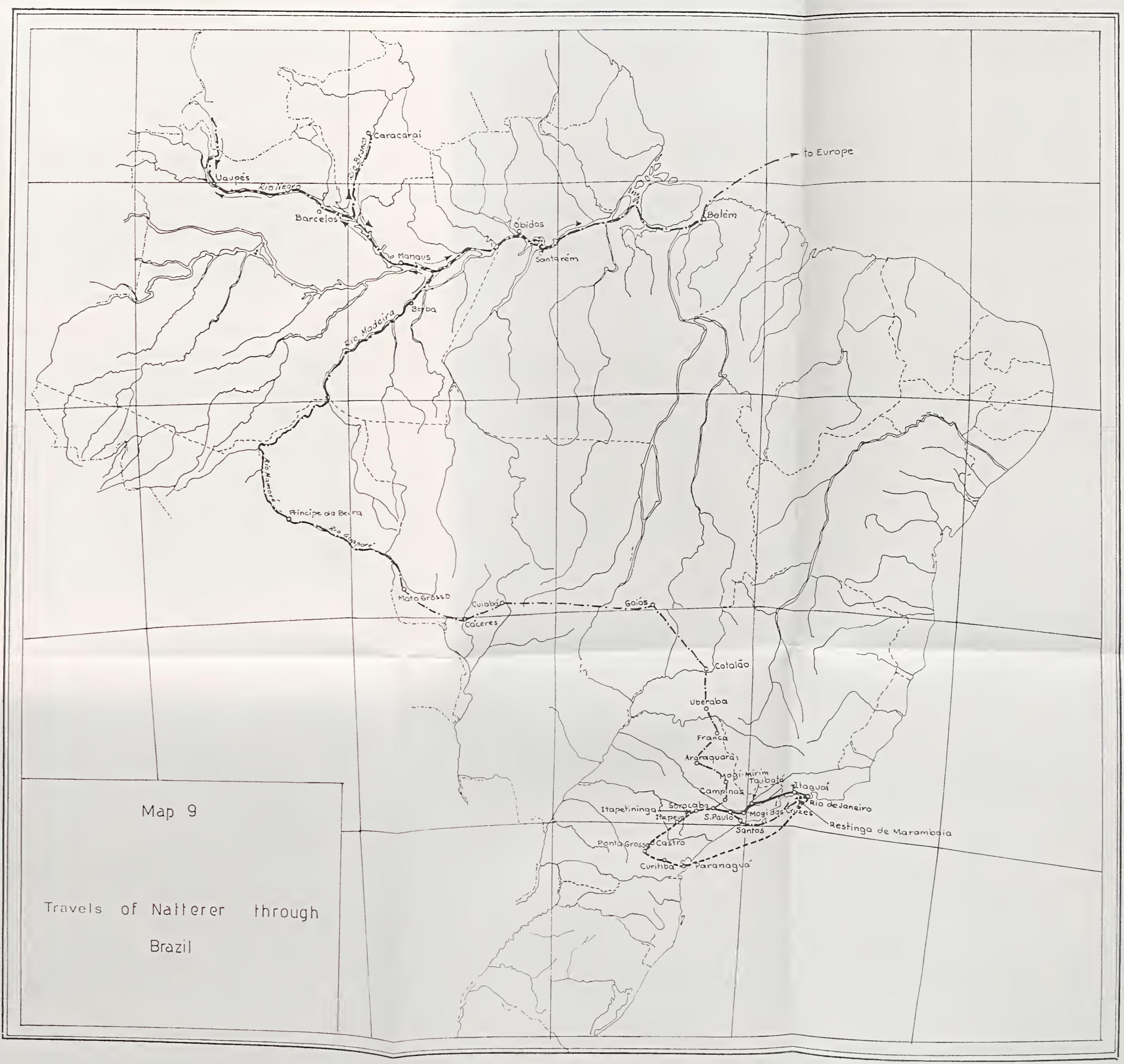

$\mathrm{Cm}$
$\mathrm{cm}$ 


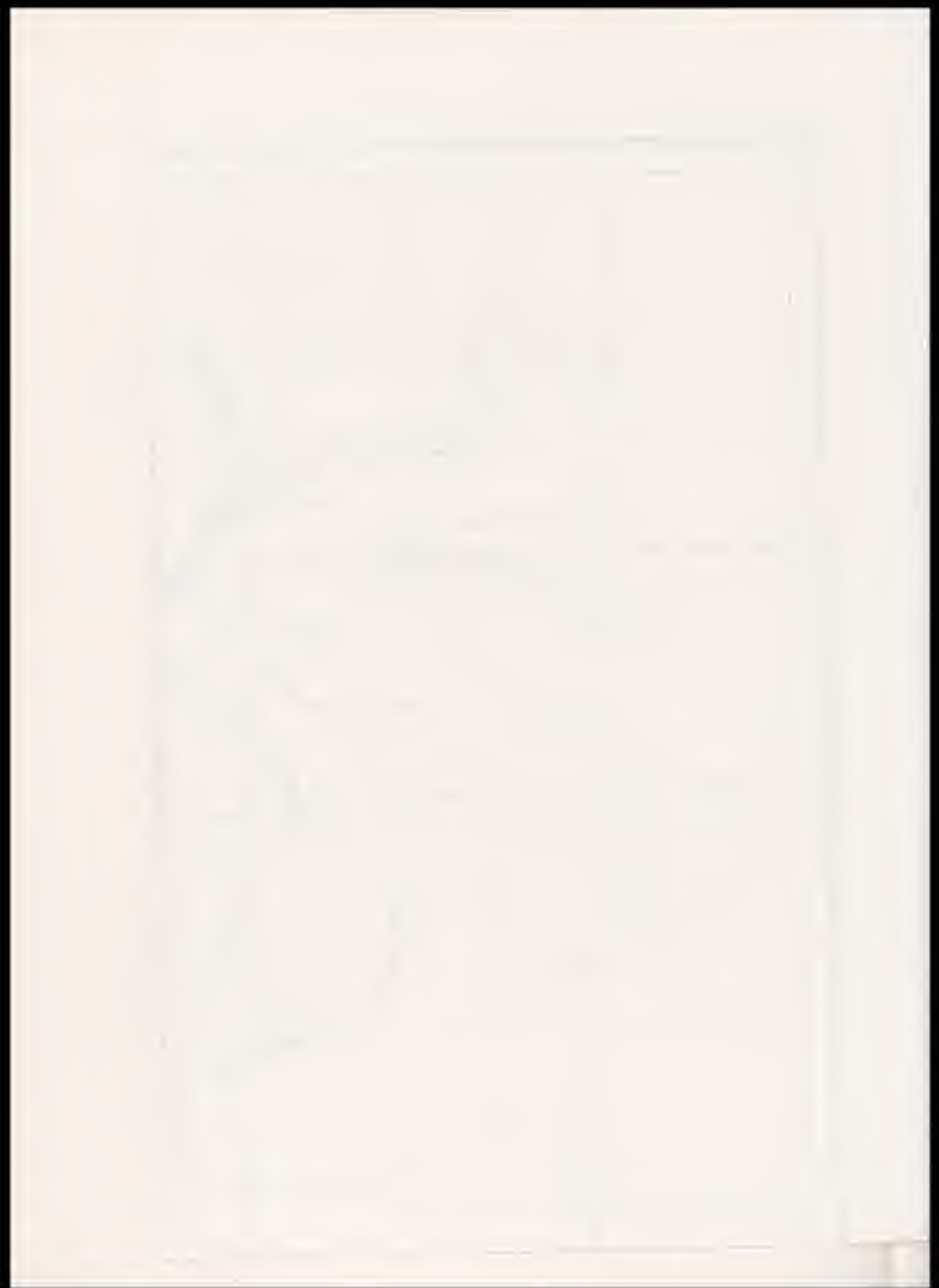


1822 to 19 March 1823. Mogi Guaçu (SF-23, 47-22d) (November 27). Continuing his trip, passing through Araraquara (SF-22, 48-22a: 6 April 1823). Batatais (SF-23, 48-21b; 7 April). Franca (SF-23, 47-21a), he crossed the Rio Grande (between 19 April to 1 June), entering the Province of Minas Gerais.

Crossing Minas Gerais via Uberaba (SF-23, 48-20b), Rio Araguari or das Velhas (10 June), and Rio Paranaiba (18 June). Natterer and Sochor went on to the Province of Goiás.

In Goiás they went by way of Parnaiba de Goiás (SE-22. 48-18c; 20 June 1823). Catalão (SE-23, 48-18d; 21 June), crossed the Rio Verissimo (SE-23, 48-17d; 23 June), passed by Jaragua (SF-22, 49-16a; 22-25 July), and reached Vila Boa, the capital of the Province (presently city of Goiás, SD-22, 50-16a). remaining there from 2 August to 14 September 1823. Proceeding westwards, after crossing the Rio Araguaia (SD-22 52-16b; 10 October to 15 November 1823), they entered the Province of Mato Grosso, reaching the Capital, Cuiabá (SE-21. 56-16a) on 23 December 1823. Natterer and Sochor remained in that city. collecting in and near it, for about one year (until the end of December 1824).

6. Journeys in the Province of Mato Grosso.

After staying in Cuiabá (SE-21, 56-16a) from 1 January 1825 to 19 June 1825. Natterer and Sochor went to Vila Maria (now Cáceres, SE-21, 58-16d), remaining there from 28 July to 28 September 1825. Going through Caiçara, they reached Jauru (SE-21, 54-19a) on 28 June 1826, after having spent the period between 29 September 1825 and 18 June 1826 in Caiçara. Leaving Jauru, the naturalists journeyed to the city of Mato Grosso (SD-21, 60-15d), remaining there from 8 October to 9 December 1826, and then going to a nearby village. 'Arraial de São Vicente' (unknown to me). where they stayed from 12 December 1826 to 10 May 1827. In that village, Natterer and Sochor were attacked by severe fevers, of which Sochor died on 13 December 1826. Natterer fortunately recovered from his fever bout, returning to Mato Grosso, and staying there from 14 May to 25 September 1827. He afterwards visited the Rio Guapore (SD-21, 60-15c; 28 September). and. passing through Cáceres (16 October), returned to Cuiabá. In the capital he remained for a while (26 October 1927 to 8 January 1828). recuperating. collecting, and arranging his collections. 
He decided then to go to the northern Provinces of Brazil. and left for good the city of Cuiaba. proceeding once more to Cáceres (10-17 April) and Mato Grosso (27 May 1828 to 15 July 1829), and reached the banks of the Guaporé River, on the Brazilian border.

7. Trip to the Rivers Guapore (border of the present State of Mato Grosso), Mamoré (border of the present State of Acre). and Madeira, in the Capitania do Rio Negro (present State of Amazonas), and the city of Borba.

From the city of Mato Grosso (SD-21,60-15d), Natterer travelled up the Rio Guaporé (SD-21. 59-15d, 60-15d; SD-20. $60-14 c, 63-13 b, 64-13 a, 65-12 a)$, passing the mouth of the Rio $V$ erde on 28 July 1829, next the mouth of the Rio Cabixi, and reaching the Forte do Principe da Beira (SD-20, 64-12c; now in the Territory of Rondonia), on 10 August. Leaving on the 18th. he sailed down the Rio Guapore, entering afterwards the Rio Mamore and the Rio Madeira (SC-20, 65-10a, 65-10c, 64-9c, 63-8c; SB-20, 63-7b, 61-5d, 61-5b; SA-21, 59-4b), finally reaching the city of Borba (SB-21 60-4d), on 24 Norember 1829. In Borba he remained until 25 August 1830, meanwhile visiting several places in the neighborhood.

8. Journey from Borba along the Rivers Amazons and Negro to the border of Venezuela, and return to Barcelos.

Leaving Borba, Natterer proceeded down the Rio Madeira. passing to the south of the Island of Tupinambarana (SA-21. 58-3b). and arrived at the mouth of the Madeira in the Amazons River near the city of Parintins (SA-21, 56-3a). From there he proceeded up the Amazons to Barra do Rio Negro (Manaus. SA-20, 60-3c: SA-21.603d), where he remained from 10 September to 5 Norember 1830.

Sailing upstream from Manaus on the Rio Negro, Natterer passed Moura (SA-20, 62-1d). Barcelos (SA-20, 63-1a). Sāo Gabriel (now Uaupés, SA-19, 67-0c; 3-4 January 1831), and São José de Marabitanas (NA-19,67-1d), reaching San Carlos (NA-19, 2-67c) in Venezuela on 15 Eebruary 1831. He proceeded then to the mouth of the Casiquiare, and returned to São José de Marabitanas on May 23. He explored afterwards several tributaries of the Rio Negro - the Rio Xié (NA-19.68-2b. 67-1a). from 28 May to 6 June: the Rio Içana (NA-19.68-1b). on 9 June, going upstream until 27 June (NA-19.69-2c), then 
returning to the Rio Negro, to the city of Içana (NA-19,68-1b); back on the Rio Negro, he proceeded to the Rio Uaupés (NA-19. 69-1c, 60-0a) from 1-10 July, and went back to Barcelos (SA-20, 63-1a), on 23 August 1831.

9. Voyage from Barcelos to the Rio Branco (in the present Territory of Roraima), and down the Amazons to Santarem (in the present State of Pará).

Natterer remained in Barcelos from 23 August to 5 September 1831. going then to the mouth of the Rio Branco, a major tributary of the Rio Negro. On 24 September he started travelling up the former to the mouth of the river Mucajai (NA-20, 61-3d: 24 September 1831 to 2 July 1832). Descending the Rio Branco and the Rio Negro, he arrived at Manaus (SA-20, 60-3c: SA-21, 60-3d), where he stayed from 29 August 1832 to July 1834. During this long period he collected extensively in and around the city, and, after preparing all his collections, decided to go down the Amazons River. After stopping at some cities along the river, he entered the Province of Grão-Pará (present State of Pará), and arrived in Santarém (SA-21, 55-2d) in August 1834.

10. Voyage from Santarém to Belém and departure for Europe.

Natterer left Santarém in August 1834, and, after visiting some cities down the Amazons River (see the voyage of Spix and Martius for cities between Santarém and Belém), arrived at the city of Belém in September 1834. His plan was, in 1835. to go down the Atlantic coast of Brazil through the Provinces of Maranhão, Ceará, Rio Grande (do Norte), Paraiba, Pernambuco, and Bahia. From Bahia he intended to sail to Rio de Janeiro, since that Province and that of Espirito Santo had already been explored ornithologically by Prince Maximilian zu Wied-Neuwied. However, a revolution in the northern and northeastern Provinces of Brazil, the 'Cabanagem', rendered Natterer's plan impossible, and he remained in Belem, collecting near the city, until September 1835 . All his live animals were killed and eaten by the revolutionaries. After organizing his enormous collections and carefully packing everything. Natterer decided to return to Europe.

He embarked on 15 September 1835, aboard a British ship. with his wife. Dona Maria do Régo, whom he had married in the Rio Negro, and his three daughters, all born in Brazil. 
After his return. Natterer was employed by the Imperial Museum of Natural History in Vienna. There he started a critical work on general ornithology, travelling for that purpose from 1838 to 1840 , to northern Germany. Denmark. Sweden and Russia, and then through south Germany, France, England and Holland. However, death caught him in the middle of his work, on 17 June 1843, at the age of 56. His wife and two daughters died soon after their arrival in Europe, leaving only his daughter Gertrud, who later married Julius Schröckinger, Baron von Neudenberg. To them we owe the biographical information on Natterer published by Goeldi (1895).

Natterer's collection, gathered during 18 years of strenuous efforts in Brazil, were deposited in the Museum of Vienna, and comprised:

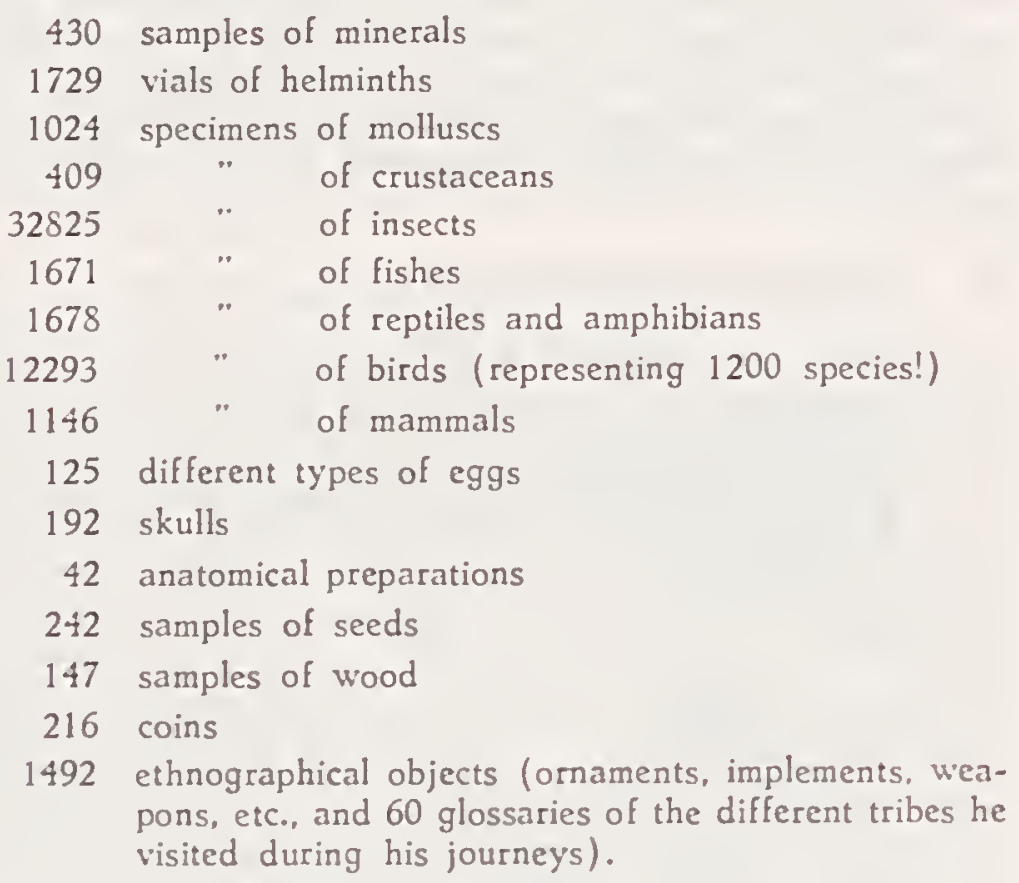

A simple calculation show's that he must have prepared, as average, 2 bird skins a day. for every day during his 18 years in Brazil. not counting Sundays and holidays, days employed in travelling, etc. 
Five years after his death, in 1848, a great fire destroyed the ancient 'Imperial Cabinet of Natural History' in Vienna. In the catastrophe were lost the collection of skeletons, part of the fishes, almost all his manuscripts and journals relating to the Brazilian journeys; the other collections were fortunately saved (Garcia, 1922; Goeldi, 1896; Ihering, 1902; Pelzeln, 1871: Stresemann, 1951).

\section{Kamerlacher}

Very little is known about the private doctor of Empress Leopoldina, Johann KaMerLacher. He came to Brazil aboard the corvette "Dom João VI", with the train of the Archduchess, but nothing is known of his activities in Brazil. Schiner studied specimens collected by Kamerlacher in Oriçanga, near Mogi-Mirim (SF-23, 47-22d). State of São Paulo. It is very probable that he travelled with Natterer from Rio to São Paulo (see Natterer's second trip). and then proceeded to the north of the Province of São Paulo, while Natterer and Sochor stopped at Ipanema. Kamerlacher must have followed the same itinerary as Natterer's fifth trip. but we do not know how far he did go. According to Oberacker (1963: 64), Kamerlacher returned to Europe in 1819.

Bescke

Very rich collections from Brazil were also sent to European Museums through the efforts of a certain "Bescke". Actually, there existed two "Besckes" (or Beske, Beské, Besche). The son, CARL HeINRICH (or Charles Henry, as he called himself later) BESCKe, and the father. Christian Friedrich Beske, seem to have been commercial agents, who, during their trips to North and South America, the East Indies, etc., collected insects and also received collections from friends and relatives living in those areas.

Christian Friedrich Carl Bescke made a voyage in 1821 to Buenos Aires, Rio de Janeiro and Bahia (see Germar's Mag. d. Ent. 4: 441-442). The materials obtained were studied by Wiedemann. Bescke senior died in 1824 . 
The son, Carl Heinrich Bescke collected on the coasts of Guinea in 1831 (see Isis 8: 10. 1931), and later became established in the city of Nova Friburgo (SF-23, 43-22d), in the State of Rio de Janeiro, Brazil.

He was a tremendous collector, being especially interested in butterflies, which he reared at home in Nova Friburgo. A large part of his collections went to ron Winthem. who distributed it for study (Weidner, 1967: 108-112). Bescke wrote some articles (Revue d'Entomologic 4: 73-100, 101-102, 1834), about his wanderings in the State of Rio de Janeiro. especially relating to butterflies. It is probable that many of the Tachinidae studied by Brauer and Bergenstamm were reared by Bescke in Nova Friburgo.

Bescke Jr. was in those days a well-known collector, being frequently visited by naturalists arriving in Rio de Janeiro. Ida Pfeiffer, for instance, who visited him in 1864 makes the following comments (Pfeiffer, 1880: 67): "5 October 1846. The little town of Novo-Friburgo (sic), or Morro-queimado, founded about 20 years ago by German and French Swiss colonists, still consists of no more than a hundred brick houses. A large part of the houses forms an extremely broad street, and the others are placed all about them.

Already in Rio de Janeiro we hear much about Monsieur Bescke. We promised ourselves not to fail to visit him.

Monsieur Bescke is a naturalist and lives in Novo Friburgo with his wife, who is nearly as well informed as he. We had many interesting conversations with him; they showed us strange collections of quadrupeds, birds, snakes, and insects. Among the latter we found samples more remarkable than in the museum in Rio de Janeiro.

Monsieur Bescke. who always has numerous orders for objects of natural history. makes frequent shipments to Europe." Pfeiffer, for instance, who visited him in 1846 makes the following impressions (English translation by G. C. Steyskal): "In New-Freiburg lived a collector well-known to me for years, Herr Carl Heinrich Bescke from Hamburg, with whom I had long been corresponding and who with his advice could be especially useful to me in my goals and their attainment. On that account. I had determined to look the place up first of all. Herr Bescke complied with all my wishes, showed me every newly received animal, and placed his entire rich stock at my disposal. The metamorphoses of insects especially occupied my attention, and since Herr Bescke always had a few dozed caterpillars being 
reared, there was no lack of opportunity to make drawings and descriptions of them. The greatest difficulty was always the determination of their food-plants; one got to see only the leaves, and one usually did not even know whether the leaf before him was from a tree, an herb, or a vine. One never saw any flower, let alone a fruit, and the scientific evaluation of the vegetation was therefore impossible. I had to abandon completely any effort to secure exact data concerning foodplants: it was always hopeless." (Burmeister, 1853: 154).

According to Burmeister (l.c.). Bescke died of dropsy on 5 December 1851.

\section{Lund and Claussen}

Among the naturalists of this period there remain to be considered in this chapter Lund and Claussen.

Peter Wilhelm Lund was born in Copenhagen, Denmark, on 14 June 1801. He was the son of a clothes merchant of Jutland peasant stock. His mother was born in Ditmark. After finishing his basic courses, he entered the Academy of Medicine in Copenhagen, but after a few years abandoned the medical course for the study of natural sciences, especially botany and zoology. In 1824 he published two theses, one on medicine, later translated into several languages, and for a long time used as a reference work, and the other on zoology.

As he suffered from pulmonary tuberculosis, a disease that had killed several members of his family, Lund decided in 1825 to look for a place with a milder climate and also favorable to the pursuit of his researches on natural history. He sailed from Copenhagen to Brazil on 28 September 1825. The crossing of the Atlantic was very rough, lasting for two months and ten days: he therefore arrived to Rio de Janeiro on 8 December 1825.

Lund remained in Rio for some days, until he could, with the help of the Dutch Consul. rent a house in Niterói (SF-23. 43-23b). opposite Rio de Janeiro, across the Bay of Guanabara. During his stay he collected plants and insects. After spending six months in Niteroi. Lund returned to Rio, at the request of the Dutch Consul, Mijnheer Brender Brandis, in whose company Lund lived until February 1826. After that, he went to live in 
Nova Friburgo (SF-23, 43-22d), on the Serra dos Órgãos. There he remained for four months, moving to a nearby farm. called 'Rosário', where he stayed for more than a year, assembling an important collection of insects and plants.

The climate of those mountains being very favorable to his health, Lund gained new energies and undertook a trip to Campos (SF-24, 41-22a) and São Fidélis (SF-24, 42-bb2). Later, with the Danish diplomat. Baron Loevensterns, he took one more trip. to the border of Minas Gerais, through the Serra dos Orgãos and the Rio Paraiba.

In the middle of January 1829. Lund returned to Denmark, arriving in April. His zoological collections were sent to the then Museum of Natural History of Copenhagen and to Prince Christian (later King Christian VIII) of Denmark, and were afterwards studied by Wiedemann.

In the fall of 1829 he travelled through Europe, to Berlin, Vienna, several cities of Italy, and France, visiting several museums and having contacts with Humboldt, Milne-Edwards, Cuvier, and others.

In 1833 he returned to Brazil, where he would remain for the rest of his days. With the German botanist Ludwig Riedel he undertook a long journey to the interior of the country. Returning from that trip. near the village of Curvelo, in Minas Gerais, Lund was resting in a 'pouso' for mule trains, when he was surprised by hearing a man speak in Danish, the last thing he could have hoped to hear in the interior of Brazil. Thus he met his compatriot Peter Clausses. Claussen was born in Copenhagen in 1804. He was forced to abandon his country due to some "dishonest affairs" ("ab res inhonestas patriam relinquere coactus": Urban. 1908), and came to Brazil in the time of Emperor Dom Pedro I, where he joined the Brazilian army. Soon afterwards, he established a liquor business, and travelled to the interior selling his wares. During the 1825-1828 war with Argentina he was employed as a scout. Next he operated a store in Cachoeira do Campo. Minas Gerais, and made so much money that he acquired a farm, named 'Porteirinhas', near Curvelo.

It was exactly in this village that Claussen and Lund met. Claussen was rery well known in the region, and was called by the people "Pedro 'Cláudio" (Claussen) Dinamarquès". On Claussen's farm. Lund saw for the first time the fossil vertebrates 


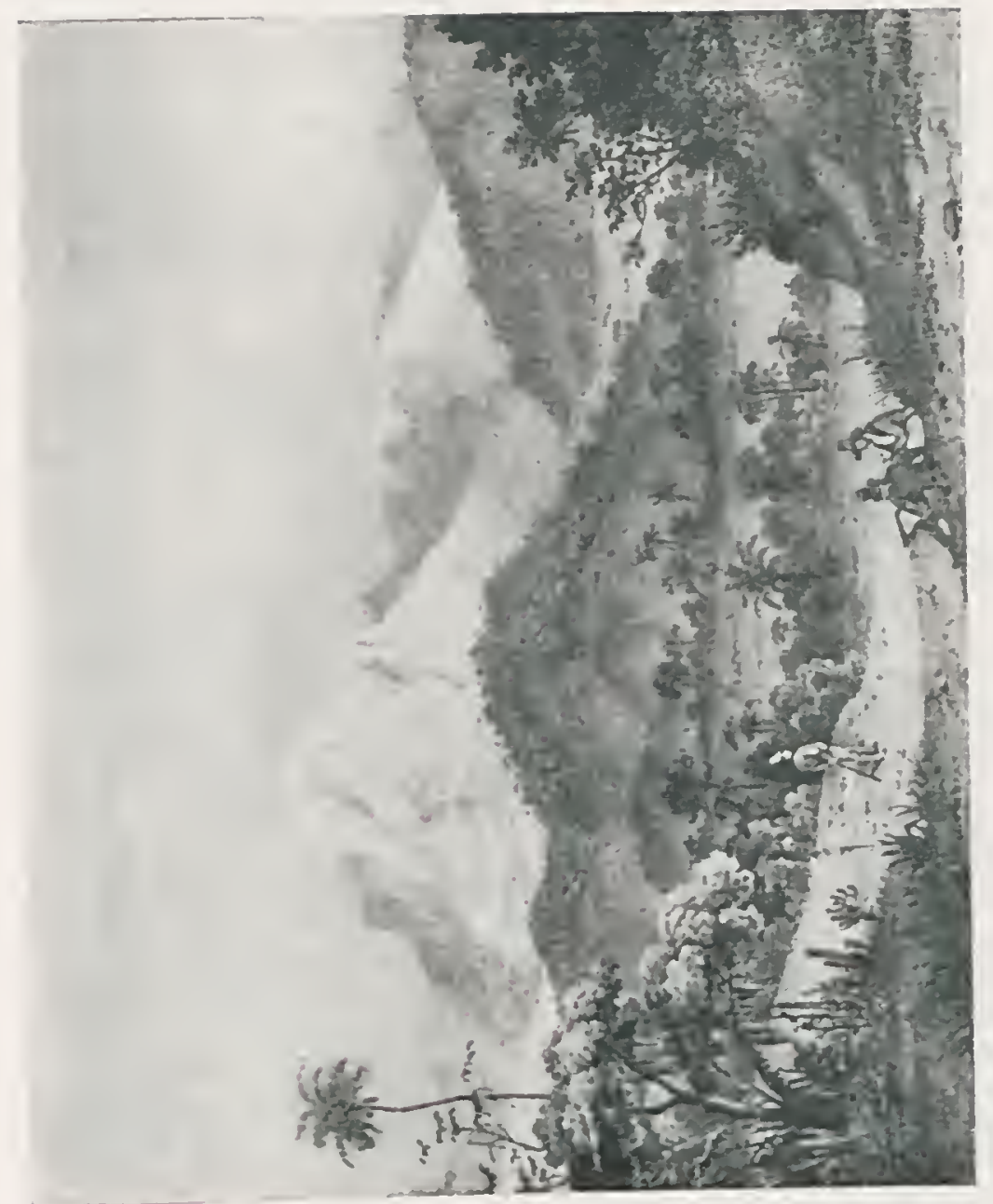

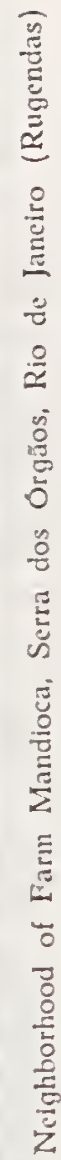

|

$\mathrm{cm} 1$ 2 3 $\begin{array}{llllll}11 & 12 & 13 & 14 & 15 & 16\end{array}$ 


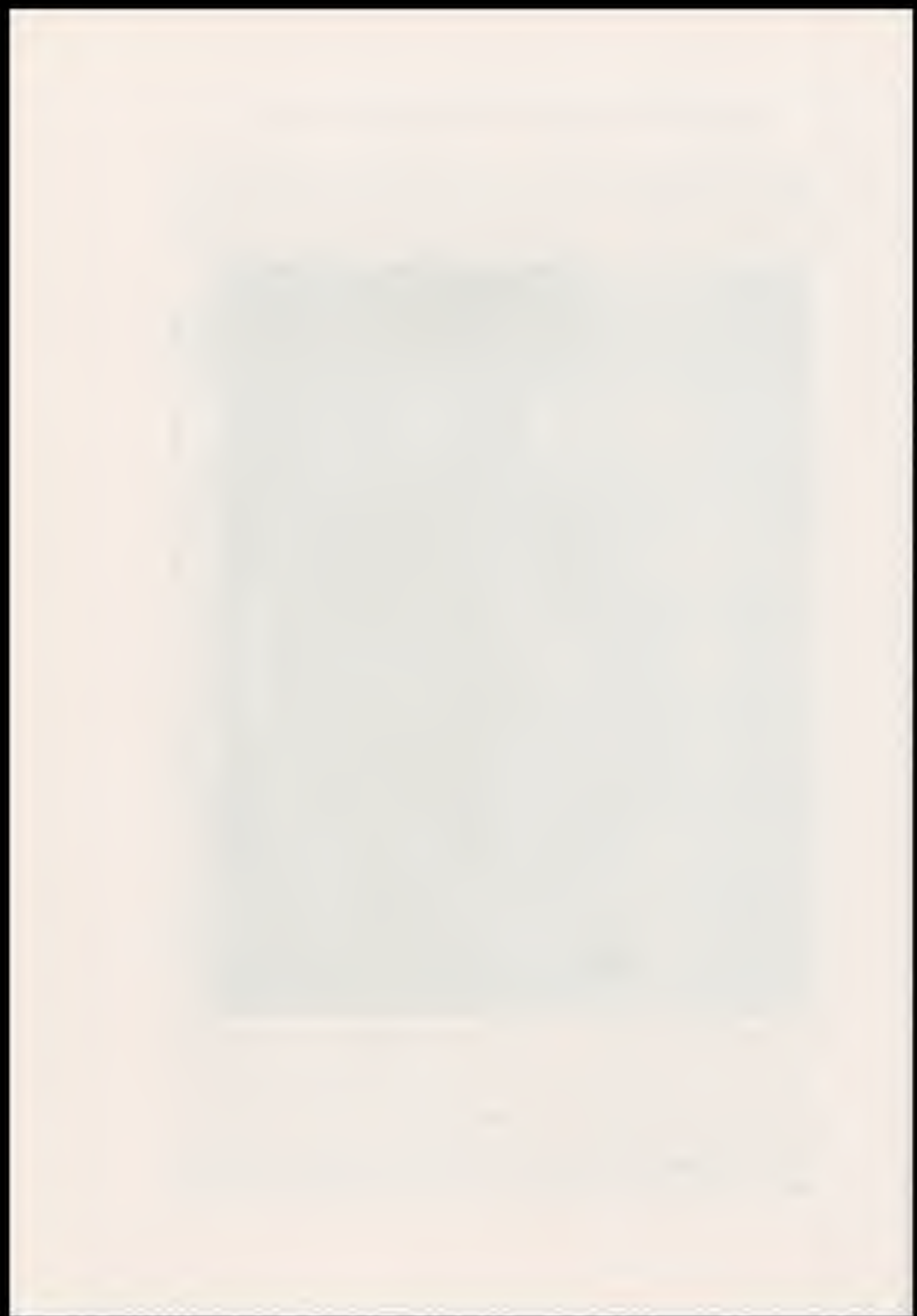

III||||||||||||||||||||||||||||||||||||||||||||||||||||||||||||||||||||| S

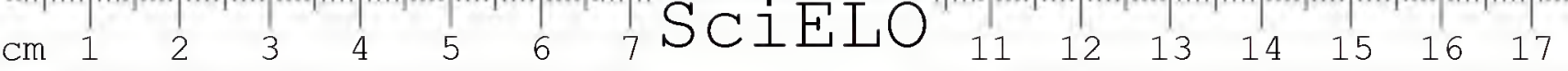


whose study would bring him everlasting fame. Lund found many caves in Minas Gerais with fossil bones, which he studied during his stay in Brazil, sending several scientific papers to the Royal Society of Denmark.

On 10 January 1845, Lund sent to Denmark his collections of fossils with a letter to King Christian VIII, his personal friend and protector, in which Lund said that he hoped that the collections would be used in the interests of Science, due to their great value ("at denne Samling, paa Grund af dens videnskabelige Vaerd og Interesse, saa snart og fuldstaenring som mulig kommer til Nytte for Videnskaben").

When the last boxes of fossils arrived to Denmark, in the middle of 1849. King Christian VIII was no longer living; the country was at war, and had several difficult social and political problems. The Royal Museum of Natural History did not have sufficient room to house the enormous collections, and they were left in a forgotten corner. They were brought to light only many years later, as a result of a campaign that Lund's nephew. Troes Lund, undertook in 1859 in the newspaper of Ploug, the 'Faedrelandet".

With advancing years, Lund's health worsened. The great palaentologist died in 1880 at the age of 79 , almost blind, surrounded by the respect and veneration of the simple inhabitants of the small village of Lagoa Santa, Minas Gerais, where he had lived for so many years working peacefully on his fossils. There he was buried, and his tomb, with a monument, can still be seen in Lagoa Santa (Paula Couto, 1950).

Let us return now to Claussen - he travelled in 1834, with Count F. de Castelnau and H. A. Wedell (see Chapter VIll) to Ouro Prèto (SF-23, 44-20d). He made other trips to Cachoeira do Campo (now Cachoeira, SE-23, 44-19b). Currelo (SE-23. 44-19a). Itabira (SE-23, 43-20a). Itacolomi (SE-23, 44-19d). Serra do Caraça (Mun. of Santa Bárbara, SE-23, 43-20a), and to the Rio São Francisco, all localities in the State of Minas Gerais.

In 1840 and 1842 he travelled to Europe, selling his collections of plants to Belgium and England, and his insects to the Museum of Paris. The Diptera were later studied by Macquart (Urban, 1908). 


\section{References}

Anonymous

1863. Notice biographique sur M. Edouard Ménétriès. Horac Soc. Ent. Ross. 2 : 1-7, portrait.

Blake, A. V. A. Sacramento

1893. Diccionario bibliographico brazilciro 2 : vm +479 pp. Imprensa Nacional, Rio de Janeiro.

1898. Diccionario bibliographico brazileiro 4 : 529 pp. Imprensa Nacional, Rio de Janciro.

Bokermann, W. C. A.

1957. Atualizaçāo do itinerảrio da viagem do Principe de Wied ao Brasil (1815-1817). Arq. Zool. Est. Săo Paulo 10 : 209-251. 4 maps.

Burmeister, $\mathrm{H}$.

1853. Reise nach Brasilien. durch die Provinzen von Rio de laneiro und Minas geraès. mit besonderer Rücksicht auf die Nafurgeschichte der Gold-und Diamantendistricte, vII + 608 pp., 1 map. Georg Reimer Verlag. Berlin.

Fairchild, G. B.

1967. Notes on Neotropical Tabanidae (Diptera). VII. The species described by C. R. W. Wiedemann. Pacific Insects 9 (1) : 73-104.

Feijó, J. da S.

1800. Carta topographica do Cearà à mina de Salpetra descoberta no sitio de Tatujuba, na distancia de 55 legoas da villa de Fortaleza, $0.175 \times 0.230 \mathrm{~m}$ (unpublished map in the Biblioteca Nacional. Rio de Janeiro).

1809. Carta demonstrativa da Capitania do Ceasá para servir à sua historia geral. $0.524 \times 0.740 \mathrm{~m}$ (unpublished map in the Biblioreca Nacional, Rio de Janeiro).

1810. Planta demonstrativa da Capitania do Ceará para servir de plano à sua carta topographica, delineada pelo sargento-mór naturalista J. da S. Feijo, $0.413 \times 0.536 \mathrm{~m}$ (unpublished map in the Biblioteca Nacional, Rio de Jaseiro).

1810. Preambulo ao ensaio philosophico e politico sobre a Capitania do Ceará para servir à sua historia geral, Rio de Janeiro. 
1814. Memcria sobre a Capitania do Ceará, escrita de ordem superior pelo sargento-mór, J. da Silva Feijó. Jornal Literário "O Patriota" 1814 (Jan-Apr). (Reprinted in Rev. Trim. Inst. Hist. Ceará $3: 5-25)$.

1814. Memoria sobre as minas de ferro do Cangati do Choró na Capitania do Ceara, escripta em 1814 (unpublished; portions of this article were included in 1874, by Senator Pompeo in his "Ensaio estatístico do estado do Ceará. vol. 1).

(no date). Memoria sobre as minas de ouro do Ceará (unpublished; Biblioteca Nacional, Rio de Janeiro).

Fleiuss, M.

1922. Historia administrativa, pp. 952-1067. in Instituto Historico, Geographico e Ethnographico Brasileiro: Diccionario Historico, Geographico e Ethnographico do Brasil 1 : 1688 pp., illus.

Florence, $\mathrm{H}$.

19ł2. Viagem fluvial do Tietẻ ao Amazonas de $1 S 25$ a 1829,218 pp., pls. Comp. Melhoramentos, São Paulo.

Freyreiss, G. W.

1902. Viagem a varias tribus de selvagens na Capitania de Minas Gerais: permanencia entre ellas, descripção de seus usos e costumes (traducção de Alberto Löfgren). Rev. Inst. Hist. Geograph. Säo Paulo 6 (1900-1901) : 236-252.

1907. Viagem ao interior do Brasil nos annos de 1814-1815 pelo naturalista G. W. Freyreiss (traduzido pelo dr. Alberto Löfgren). Rev. Inst. Hist. Geograph. São Paulo 11 : 158-228.

Garcia. R.

1922. Historia das explorações scientificas, pp. 856-910, in Instituto Historico, Geographico e Ethnographico Brasileiro, Diccionario Historico, Geographico e Ethnographico do Brasil 1 : 1688 pp.. illus.

Goeldi, E. A.

1895. Johhannes von Natterer. Biographia. Bol. Mus. Paraense $l$ : 189.217, portrait.

Hagen, $H$.

1855. Monographic der Termiten. Linnaca Entomologica $10: 1-144$. 
Hoehne, F. C.

1942. Notas bio-bibliográficas de naturalistas botânicos, in F. C. Hoehne, M. Kuhlmann E O. Handro, O Jardim Botânico de São Paulo. $656 \mathrm{pp}$. illus.

Hoffmannsegg, J. C., Count von

1798. Instrução completa sobre o methodo de apanhar, mancjar, conscruar e empacotar os Insectos, para serem enviados dos Paizes Estrangciros a Europa : para uso das Pessoas que quizcrem empregar-se na caşa delles em beneficio do Author, 67 pp., Lisboa.

Ihering, $H$. von

1902. Natterer e Langsdorff, exploradores antigos do Estado de São Paulo. Rev. Mus. Paulista 5 : 13-34.

Kotzebue, O. von

1821. Entdeckungs-Reise in dic Süd-Sec nach der Berings-Strasse zur Erforschung einer nördlichen Durchfahrt, unternommen in Jahren 1S15. 1S16. 1S17 und 1S1S, auf Kosten des Herrn Reichs-Kanzler Grafen Rumanzolf auf dem Schiffe Rurick $I$ : 168 pp., 2 pls.. 2 maps; 2 : 176 pp., 5 pls., 3 maps; 3 : 240 pp., 13 pls., 1 map: Hoffmann, Weimar.

Krusenstern. A. G. di

1818. Viaggio intorno al mondo fatto negli anni 1503-4-5 \& 1506 dordine di Sua Macstả Imperiale Alcssandro Primo su $i$ vascelli la Nadeshda e la .Neva 1 : 255 pp.. 3 pls.. 1 map: 2 : 297 pp., 4 pls.; 3 : 377 pp.. 4 pls. G. Sonzogno, Milano.

Lacerda. J. B.

1905. Fastos do Muscu Nacional do Rıo de Janciro. Recordasoócs historicas c scientificas fundadas $\mathrm{cm}$ documentos authenticos $c$ informaşōes veridicas, $\mathrm{N}+18 \mathrm{sp}$., pls. Imprensa Nacional, Rio de Janeiro.

Ladislau Netto, (-).

1870. Invessigaşöes historicas e scientificas sobre o Museu Imperial e Nacional do Rio de Janciro acompanhadas de uma breve noticia de suas colleçóes e publicadas por ordem do Ministerio da Agricultura, $w+310+x$ pp. Instituto Philomatico, Rio de Janeiro. 
Langsdorlf, G. H. vion

1812. Bemerkungen auf ciner Reise um die Welt in den Jahren 1503 bis 1S07, von G. H. Langsdorf, kaiserlichrussischen Hofrath. Ritter des St. Annen-Ordens Zweiter Classe. Mitglied mehreren Akademien und gelehrten Gesellschaften I : 12 pp. n. numb. + 303 pp., 28 pls.; 2 : 335 pp., 18 pls., 17 pp. n. numb.

Manizer, G. G.

1967. A expedição do académico G. I. Langsdorff no Brasil (1821-1828), 244 pp., illus. [Série 'Brasiliana', vol. 329], Comp. Editora Nacional, São Paulo.

Oberacker, C. H., Jr.

1963. Franz Josef Frühbeck — pintor e desenhista desconhecido. Humboldt 3 (7) : 64-67, ilus. Ubersee Verlag. Hamburg.

Paula Couto, C. de

1950. Introdução, pp. 5-26, in P. W. Lund, Memórias sübre a palcontologia brasileira, 589 pp., 56 pls., 16 figs. Rio de Janeiro.

Pelzeln, A. von

1871. Itinesarium von Natterer's Reise in Brasilien von 1817-1835, in his Zur Ornithologie Brasiliens. Resultate von Johann Natterers Reisen in den Jahren 1817 bis 1835 (Abtheil.) 5 : 1 - xx. Wien.

Pleilfer, 1.

1880. Voyage d'une femme autour du monde, 612 pp., illus. map. Librairic Hachette $\mathcal{E}$ Cíe., Paris.

Pinto, O. M. de O.

1952. Sủmula histórica e sistemática da ornitologia de Minas Gerais. Arq. Zool. Est. Săo Paulo 8 : 1-51.

Pohl, J. E.

1832-37. Reise im Innern von Brasilien, auf Allerhöchsten Befehl seinen Majestát des Kaisers ton Osterreich. Franz des Ersten. in den Jahren 1S17-1S21, 2 vols. (vol. 1. 1832; vol. 2, 1837). Wien.

1951. Viagem no interior do Brasil, cmpreendida nos anos de 1817 a 1821 e publicada por ordem de Sua Majestade o Imperador da Aus:ria Francisco Primciro I : 400 pp., pls.; 2 : 471 pp., pls. Ministério de Educaçăo e Saúde. Instituto Nacional do Livro (Coleção de Obras Raras, n 111). Rio de Janeiro. 
Screibers, C. F. A. von

1820-23. Nachrichten von den kaiserl. Österreichischen Naturforschen in Brasilien und den Resultaten ihrer Betricbsamkeit. Aus Amtrelationen der k.k. Ministerium der auswärtigen Angelegenheiten in Wien, aus den Berichten und Briefen der Naturforseher an den k.k. Hof-Naturalienkabinets-Direktor, Herrn Karl v. Schreibers, als Referenten des wissenschattlichen Altheiles der Expedition, und nach Untersuchung und Betund der eingesandten naturhistorischen Gegenstände der k.k. Hot-NaturalienkabinetsDirektion 1 (1820) : vT + 191 pp.: 2 (1823), I map. Brünn.

Sommer. F.

1954. A vida do botânico Martius, 184 pp. pls. Comp. Melhoramentos, São Paulo.

Spix. J. B. von $\mathcal{E}$ C. F. P. von Martius

1823-1831. Reise in Brasilien auł Beł̣chl S. M. König Maximilian Joseph I von Bayern. 1817-1S20 unternommen und beschricben von Dr. John. Bapt. von Spix und Dr. Carl Fricdr. Phil von Martius, 3 vols. (vol. 1, 1823; vol. 2, 1828; vol. 3, 1831), and Atlas. Munich.

(no date). Viagem pelo Brasil. 1817-1820 l : 283 pp., 2 : 332 pp., 3 : 344 pp. Comp. Melhoramentos, Săo Paulo.

Stresemann, E.

1945. Der Naturforscher Friedrich Sellow († 1831) und sein Beitrag zur Kenntnis Brasiliens. Zool. Jahrb., Abt. \&. Syst. 77 (6) : $401-425$.

1950. Die brasilianische Vogelsammlungen des Grafen von Hoffmannsegg aus den Jahren 1800 bis 1812. Bonner zool. Beitr. 1 : 43.51.

1951. Dic Entwicklung der Ornithologic von Aristotcles bis zut Gegenuart, 431 pp., 14 pls., 3 text-figs. F. W. Peters, Berlin.

Urban, I.

1908. Vitae itineraeque collectortm botanicorum, notae collaboratorum biographicae, florae Brasiliae ratio edendi chronologica, systeza. index familiarum, pp. 1-cx, in C. F. P. von Martius ct al.o Flora Brasilicnsis, enumeratio plantarum in Brasilia hactenus detectarum quas suis aliorumque botanicorum studiis deseriptae et me:hodo naturali digesias partim icones illustratas I (1): $\mathrm{Cx} \div 266+31$ pp., 59 pls. 
Weidner, $\mathrm{H}$.

1967. Geschichte der Entomologie in Hamburg. Abh. Verh. Naturwiss. Vereins Hamburg (N.S.) 9 (Suppl.) : 387 pp.

Wied-Neuwied, Maximilian Prinz zu

1820-21. Reise nach Brasilien in den Jahren 1815 bis 1917 $1: 380$ pp. (1820), 2 : Xvil + 343 pp. (1821). H. L. Brönner, Frankfurt a. M.

1958. Viagem ao Brasil nos anos de 1815 a 1817, xIX +535 pp. Biblioteca Pedagógica Brasileira, Série 5* (Brasiliana, Grande Formato), vol. 1. Comp. Editora Nacional, São Paulo. 


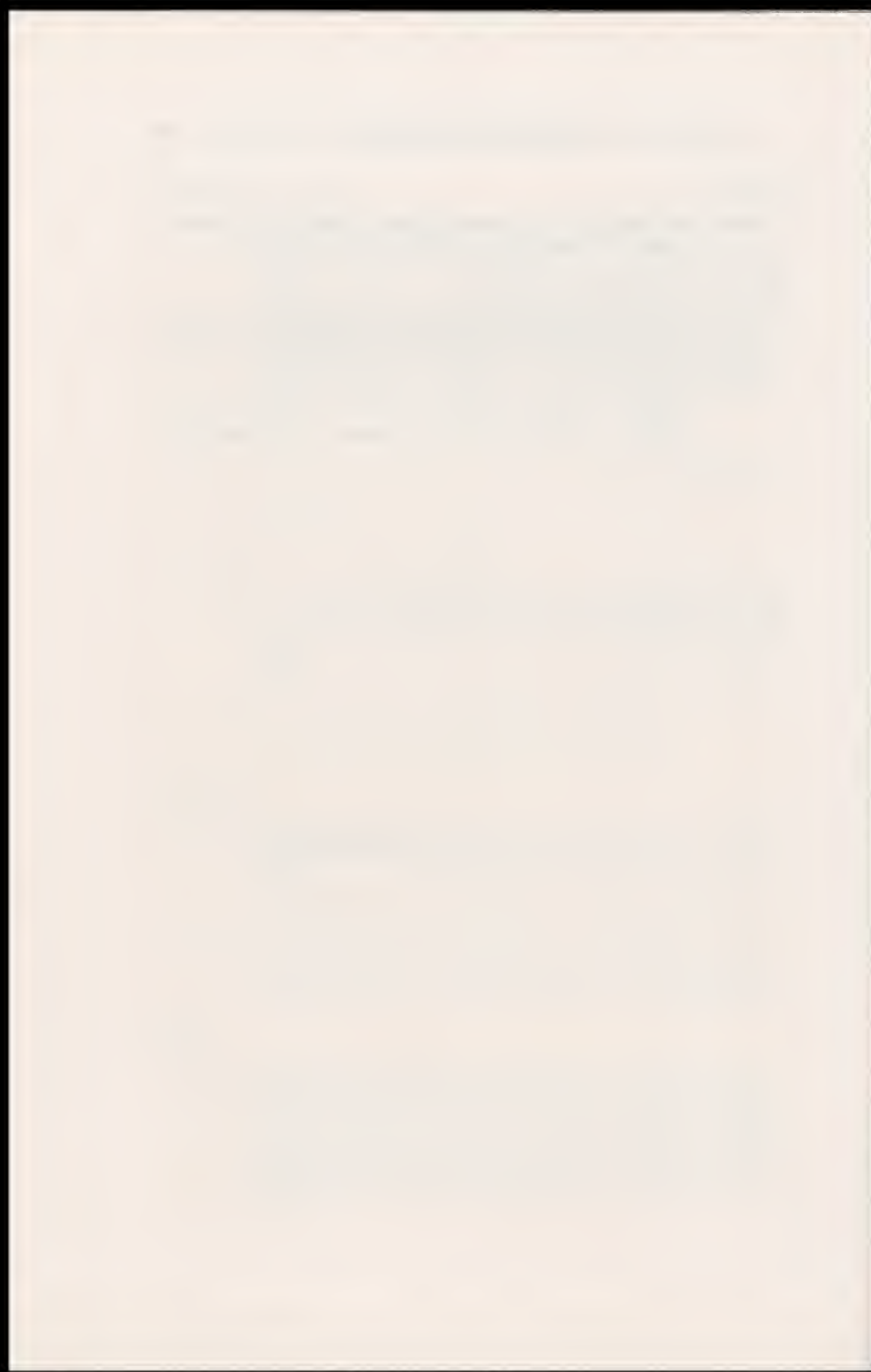




\section{Appendix to Chapter V}

1. "Portaria" (royal permit) granted to Martius and Spix, permitting their travels in the Province of Rio de Janciro: later on, the permission was extended to other Brazilian Provinces.

"Manda El-Rey Nosso Senhor a todas as Authoridades Militares ou Civis a quem esta for apresentada, e o seu conhecimento perteneer, que se nảo portha embaraço algum á livre jornada de Mrs. Spix e Mlartius. Membros da Acadcmia Real das Seienscias de Munich, aos quacs Sua Magestade tem concedido permissảo necessaria para viajar em qualquer parte dentro dos limites desta Capitania do Rio de Janciro. E determina Sua Magestade. que lhes preste nessa sua degreçăo toda a assistencia e auxilio de que precizar. logo que o pedir. Palacio do Rio de Janciro. em 12 de setembro de 1917. - Joúo Paulo Bezerra."

II. Letter of F. Sellow to the President of the Province of Rio Grande do Sul, telling about the finding of a giant fossil in Uruguay. (Unpublished manuscript in the Museu Nacional. Rio de Janeiro. Pasta 1, Documento $\left.n^{\circ} 45\right)$.

\section{"Jimo. c E.rmo. Snr!}

Empregado nihuma viagem, pelo Intcrior desta Provincia, a/ bem das sciencias naturais, tive com a minha chegada a/ Alegrete o praser de congratular-me, pela certeza q." ob/tive da feliz chegada de V.a Ex.a a esta Capial, el ouso aproveitar a oportunidade q.e hoje aleanço p./apresentar a V.a Ex.०. ainda q.e tarde em consequencial das circumstancias $\mathrm{cm}$ q.e $m \mathrm{c}$ ochava, a homenagem do/ meu respeito $c$ da minha obediencia./

Nesía mesma occasiso tendo a ousadia de solicitar/ licença para remetter as ordens de V.a Er.o. pelo favor do S.or José Maria da Silucira Vianna n'esia Cida/de, quarro caroes com productos naturacs, p." mim ulti/mamente 
rccolhidos e marcados de $M I$ e N.o 8./ N.o VIIII, X c XI. rogando a V.a Ex.c Se digna mandalos/ remetter a Secretaria do Estado dos Negocios do Imperio, $p . \&$ serem entregues ao Musco Nacional nesta Corte./

O caxão N.o VIIII contem os restos assas interessantes,/ de hum mammitero colossal, q.e recolhi os restos no/ Arapey cheio. A fama dava a cste animal hum/ comprimento de quarenta palmas, e q.e huma carcta/ nāo seria sufficiente p.c levar os seus ossos: porem/ isso achei muito exagerado. Pela inspeç̧āo destes/ fragmentos, q.e consistem $\mathrm{em}$ varios pedaços do casco//

com que a modo de Tatús era coberto, $\mathrm{em}$ o antebraço esquer/aio com a maior parte da māo e em grande parte do pél esquerdo, com a ponta da ¿ibula, parece claro q.e. com effci/to pertencia a ordem dos Cavadores (:Elfodientia:), e q.e/ o comprimento do seu corpo cra de circa 15 palmas; isso/ sededuz principalm.te da curva que forma o maior peda/ço do casco, o qual tem 24 polegadas de comprido e 10 de / alto, e ha da parte inferior c anterior do lado esquerdo./ Estc pedaço, e os mencionados ossos acharão se $\mathrm{cm}$ parte/ enterrados n'huma marga argilosa, em parte calcarca./ q.e cobre até certa altura o alvo do Arapey cheio/ e dos varios rios c arroyos da sua visinhança, os/ quaes todos correm em terreno basaltico. Sem duvida per/tence a mesma creação q.e aquelles ossantentos remar/caveis, q.e forão achados no calcareo grosseiro de Paris./ ou estes Elcphantes e Rhinocerontes q. $\mathrm{se}$ achavåo $\mathrm{cm} /$ varias partes da Allemanha c da Sibiria, ou o Mammouth do Ohio ou o Megatherium do Rio da/ Prata. Lamento q.e nāo foi possivel achar algum dente ou outras partes do craneo, $p .^{a}$ melhor escla/recimento./

Si durante a continuaçäo da minha viagem/ pela Provincia de Missües e acima da Scrra se//

se offerecesse qualquer occasiäo p. ${ }^{a}$ empregar me no ser/viço de $V .{ }^{a}$ Ex. ${ }^{a}$ : certamente terei o maior prazer $\mathrm{cm} /$ empenhar ńclla obedientissimamente todo - meu zelo./

Digna Se Extmo Senhor de acolher os protestos! firmissimos de respeito com q.e tenho a honra de ser/

\section{De V.a Excellencia}

o muito obediente scruo Frederico Scllow"

Alegrate

15 de Avril 1526

III. Sellow's last will, made in Ouro Prêto, on 29 March 1831 (unpublished manuscript, in the Museu Nacional, Rio de Janeiro, Pasta 1, Documento n*147).

"Traslado do Testamento do Dor Frederico Scllou" - Eu Frederico Sellow natural da Cid'se de Potsdamin/ no Marquezado de Brandemburgo. determino no caso de lalescer, durante as minhas viagens pela Ameri/ca o seg.e: e quero q o Consul de S. M. o Rei da Prussia na Corte do Ro de Jaño Guilherme de Theremin [corruption of "Dürming"]/ ou aquelle $q$ o substituit, c o Conselheiro d'Ambassada do mmo Rei Ignacio Franco lose Maria de Olfers. c of mais antigo Dirctor do Real Museio de Histo/ria Natural, em Berlim verifiquem a execuşo desta mis vonte. Primeira. Todos os Manus/ criptos, Desenhos, Mappas, Liuros, Impressos./ c Instrumentos Physicos e 
Mathematicos./ Relogios e Plantas Seccas, q.e possuo, encaixotadas, tal co/mo os dispus, e deixar em Canastras, ou Caixoens/ marcados com a mor de $F$. $S$. com, ou sem addiç̧ōles. seräo entregues ao Conselheiro d'Ambassada de/ S. M. o Rei da Prussia Ignco Franco Je Maria de/ Olfers, que delles fará aquelle uso, $q$ mais util. $\mathrm{e} /$ proveitoso for para as Sciencias, e especialme para/ o adiantamento dos Conhecimios do Brasil; $e$ tambem/ cuidará $q$ os Muscos publicos da Corte de Berlim, e do Rio de Jarro obtinhão sufficientes Catha/logos dos productos naturaes, $q$ estes estabelecimios de/ mim riceberão. = Segundo. Depois de concluido/ o trabalho Botanico, que sobre plantas sudame/ricanas o mmo Sr Ignco Franco Je Ma de Olfers/ julgar util fazer, ou causar de fazer as mencionadas plantas seccas, q reservei pa seme fims. e os meus Desenhos Botanicos pertencerão ao//

3o Real Musêo de Historia Nal de Berlim/ exceptuados das plantas seccas, dous exemplares/ de todas as especies, das $q^{s}$ a $\mathrm{m}^{m a}$ Colleç̧äo conta, ma/is que huma amostra, as quaes offereço como levej signal de meu reconhecimento ao Snr. Barão/ Alexandre de Humboldt e ao Snr. Ignto Frro Je Mo de Olfers : Huma lista por mim feita e assig/nada q junto a este testambo será conservada. expe/cifica os objectos mencionados, nos precedentes arjtigos e nomeio os lugares onde se achảo depositados. = Terceiro. Se acontecer $q$ depois de mor morte falescer o Snr. Igneo Fneo Je Mo de Olfers, antes del receber os assima mencionados objectos e sem/ ter encarregado pessoa alguma do arranjo, e/ da publicaşão dos materiaes, ou observaçōes re/colhidas durante as nosses viagens no Brasil/ todos os sobredos objectos serío remettidos ao $\mathrm{Mu} / \mathrm{seo}$ Real de Berlim e entregues as ordens da/ correspondente Repartị̧a do Ministerio de S. M./ o Rei da Prussia. = Quarto. $O$ meu primeiro crea/do Sebastiāo Arnal de Andreas, ou aquelle que/ o substituir, segundo particular ordem $m^{a}$ / escripta, será encarregado de conduzir quanto an/tes ao Rio de Janeiro, com os camaradas precisos,l e o meu Escravo Enrique. do lugar onde eu fales/cer, todas as canastras e caixiōes com Manus/critos. Deserhos, Mappas, Livros, Impressos./Instrumentos Physicos, e Mathematicos. marcados/ com a mea F. S. depois de fechados, e sellados./ como tambem todas as colleçōes de produtos nall

naturais, q então houver presentes, $p^{3}$ apresen/tal-as ao Consul de S. $M$, Prussiana no Ro de Janro/ valendo-se nesta diligra das Portarias q o Supremo Govo me concedeo : no caso porem q eu falescer./ durante a viagem do Matto Grosso ao Gram/ Pará, o mmo Creado as apresentará ao Consul del S. M. Bribanica na Capital do Pará. a quem/ rogo de verificar $p^{r}$ antor das sciencias a remessa/ delles pis Berlim. pr via de Hamburgo, e inter/venção do Consul Prussiano naquelle Porto./ $\mathrm{e} \mathrm{em}$ Navio seguro. $=$ Quinto $=0$ mesmo crea/do pode i'ender dos meus Cavallos, e bestas, mi/rhas aquellas. $q$ năo precisar $p^{a}$ o seu regres/so, com os mencionados volumes: ccmo $p^{m}[\mathrm{r} / \mathrm{com}$ outras superfluas, papel pardo. polvora./ chumbo, armas de logo. forsagers. e do importe./ e do dnro q achar, feitas as despezas do regresso./ dar conta ao Sr Consul, a fim q este possa pres/tar conta á Compete Repartíço do Minis/terio de S. M. Prussiana. $=$ Sexto $=0 \mathrm{~m}^{\mathrm{m}}$ Consul pa/gará segundo especificaş̌́o, $q$ deixar as meus/ Crcados. o q lhes deva, e os recompensará como jus/to for $=$ Setimo $=0$ meu Excravo Enrique fical libertado. e obtem cem mil is em metal, e a roupa $q$ deixar $=$ Oitavo. Serăo conservados desic Tes/tamento dous Exemplares, hum em Lingoa Por/tuguesa, outro $\mathrm{em}$ Allemio na $\mathrm{m}^{\text {tha }}$ Carteira/ dous exemplares $\mathrm{em}$ poder do Consul de S. M./ Prussiana no Ro de lanro. e dous em poder do Sr Igneo Freo Je Ma de Olfers. hum cumprido/ os outros nảo terảo vigor. 1. C. de O. Preto a 29 de março de 1531. Frederico Sellour." 


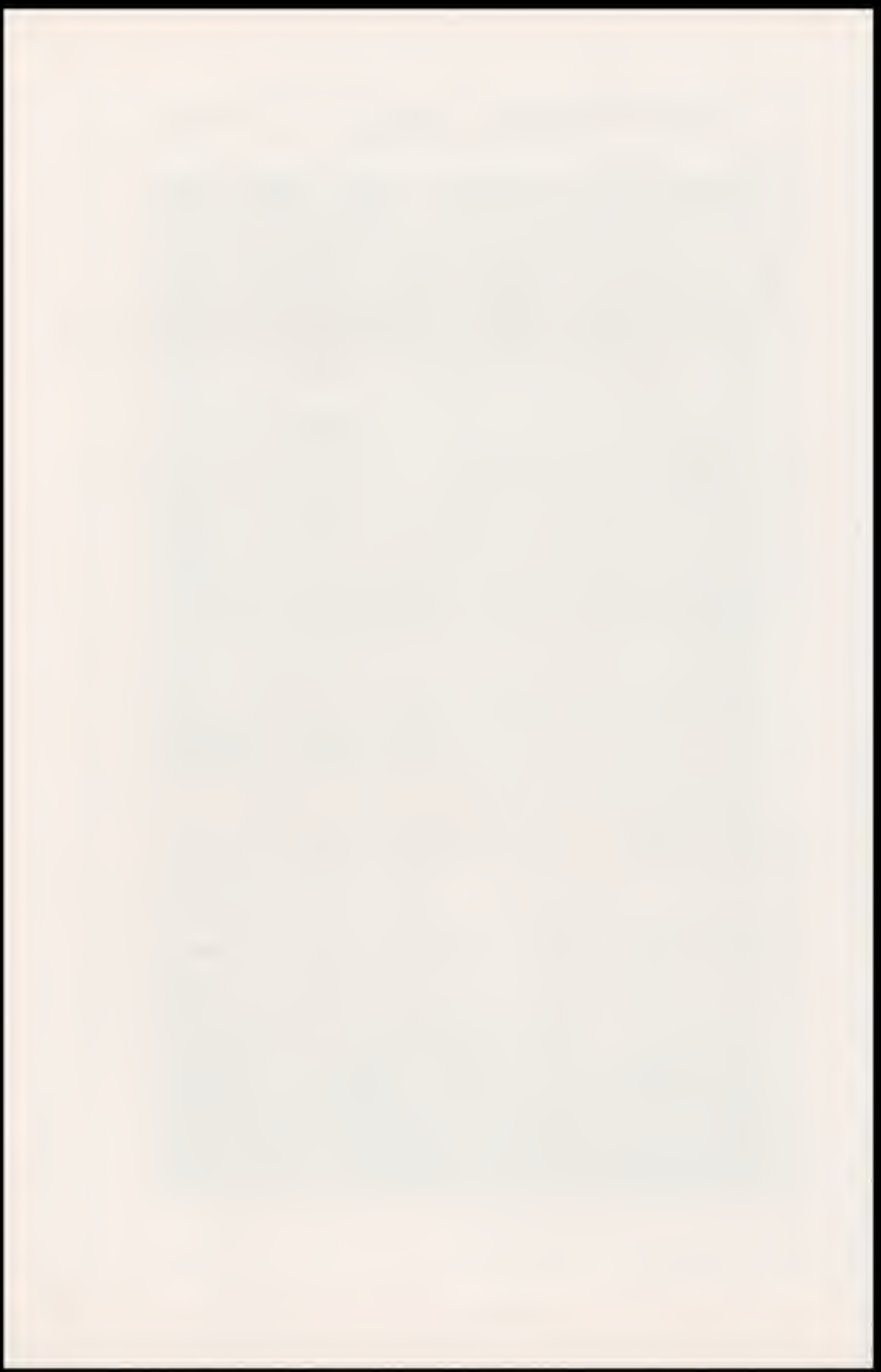


Chapter VI

\section{Collectors in Mexico and the West Indies}

\section{Forsström}

JoHAN: ERIC Forsström was born in the Parish of Trastrand. Province of Dalarna, Sweden, on 16 February 1775. He studied at Uppsala, and in 1800 became "Magister Philosophiae". making in that same year a botanical trip to Lapland and Finmarken. After passing examinations in surgery in 1801, he became a preacher in 1802, was government preacher from 1803 to 1812 and government doctor also from 1805 to 1812 on the Island of St. Barthélemy (NE-20, 18-63d) in the Lesser Antilles, from which he visited other islands, such as Saba (NE-20, 18-65a) and Guadeloupe (NE-20, 16-62b). In 1817, returning home, he became minister of the Parish of Munktrop. province of Vestmanland. Sweden, in 1819 Prior of the same, and died there on 30 May 1824. His collection went to the museum in Stockholm (Urban, 1903: 48).

Ferdinand Deppe's travels in Mexico

Mexican independence, which dates from 1821, made it possible for Europeans of any nationality to settle in Mexico and send home whatever they wanted. As early as 1823 William

| 6 
Bullock went to Mexico with the aim of acquiring abandoned gold and silver mines. Bullock was a former London goldsmith, well known as the owner of the 'London Museum' which was sold by auction in 1819. When he returned to London at the end of 1823 he brought back with him all sorts of Mexican curiosities which served for a public show, called 'New Mexico' in his 'Egyptian Hall'.

In Germany the news that mysterious Mexico had become accessible to the ordinary traveller excited the curiosity of a wealthy nobleman, the Count von Sack, 'Zweiter Ober-Jägermeister', and chamberlain to the King of Prussia. He had recently returned from a royage to Egypt and Cyprus, where he had made a small collection of birds, and at once felt inclined to visit Mexico, provided that there was a collecting naturalist of good reputation to go with him. A gardener by the name of FERDiNixid DEPPE, appointed to the Royal Gardens, was recommended for this task by Professor Hinrich Lichtenstein, director of the Zoological Museum of Berlin University. Deppe was an intelligent and energetic young man born in 1794. For a long while his connections with the Zoological Museum had been intimate, the more so as his eldest brother Wilhelm was accountant of the institution. On Count von Sack's advice Deppe gave up his job in 1821 and prepared for the voyage to Mexico. He trained himself in skinning birds and mammals, a technique which he soon mastered to great perfection. Besides, he studied books on the zoology, botany, and geography of South America, took lessons in drawing and painting, and acquired English and Spanish. However, the wayward Count remained undecided for three more years, and it was only due to the insistence of Deppe that the plan to go to Mexico was finally carried out in 1824.

The party, increased by the Count's domestic, arrived in London on 23 August 1824, where Deppe visited, besides the British Museum (the zoological section of which he judged far inferior to that of the Berlin Museum). Mr. Bullock's Show and Mr. Leadbeater's shop.

On $\delta$ October they sailed from Falmouth on board a British ship to Jamaica via Barbados. There they took another vessel bound for Alvarado, Veracruz, arriving in mid-December 1824 , shortly after the Count's footman died from an yellow fever attack.

Two years later, in January 1827. Deppe left Mexico, after having travelled via Mexico City to Oaxaca and Tehuantepec and back via Oaxaca to Alvarado. He and William Bullock's 


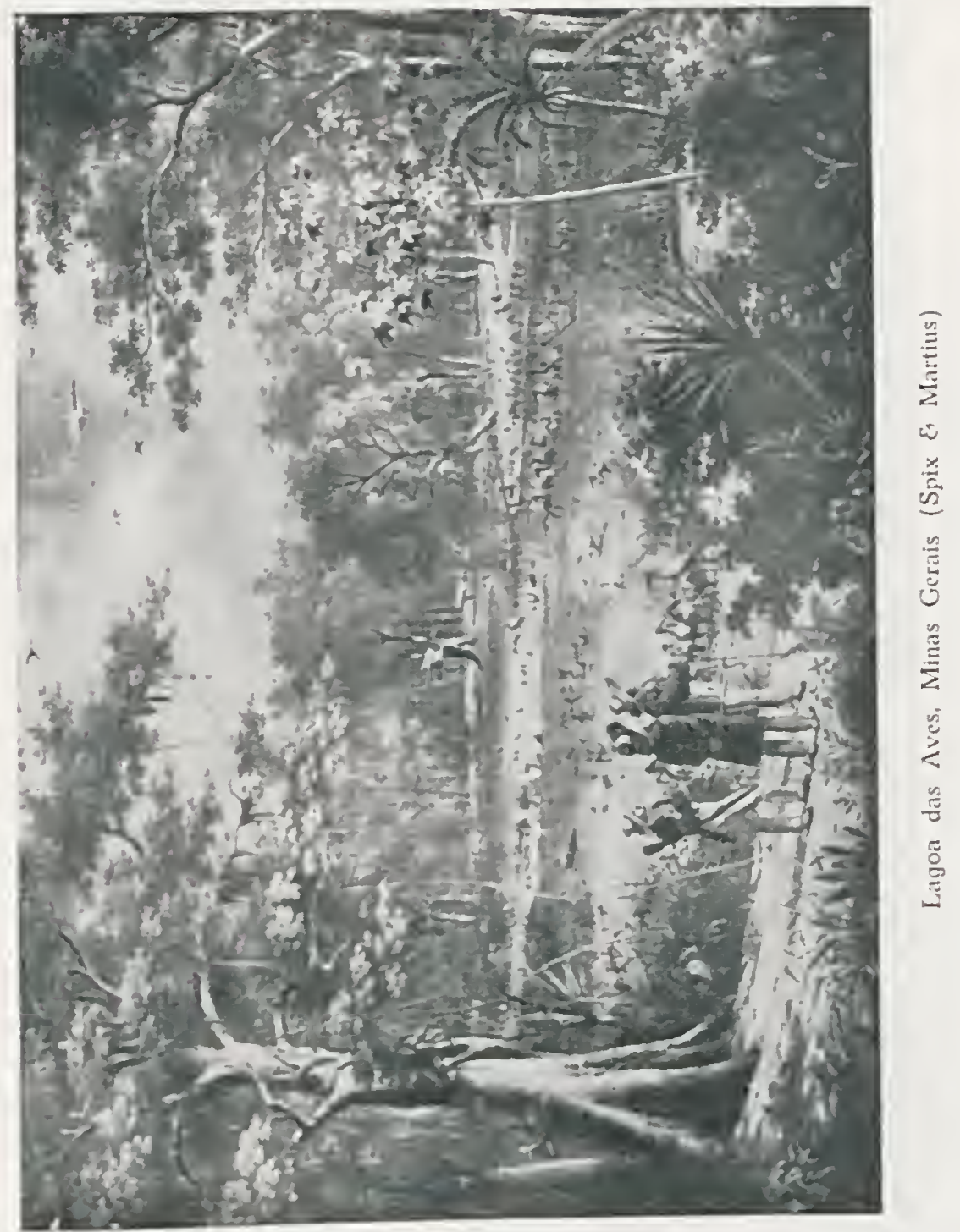




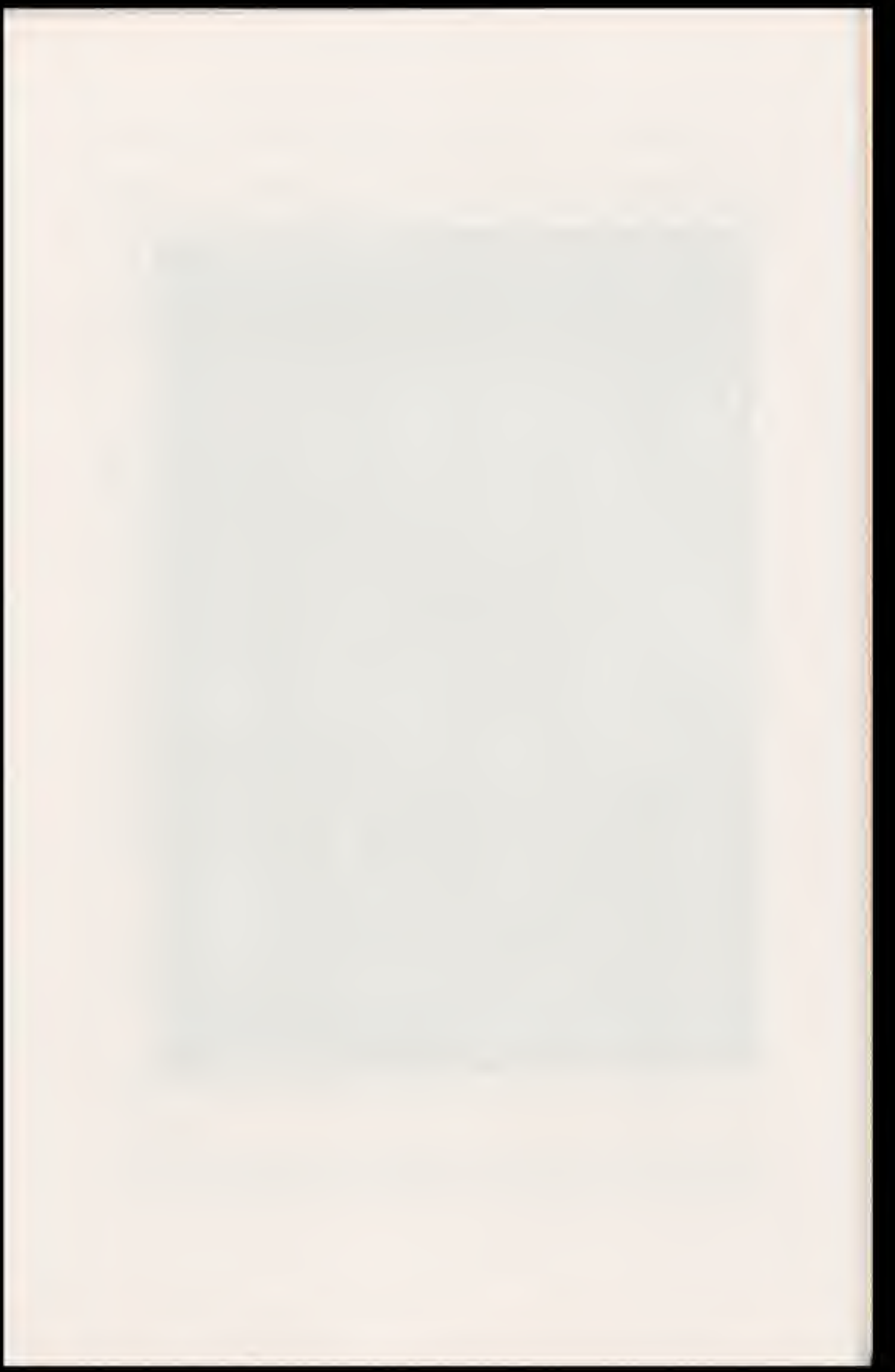


son, who joined him on the voyage from Mexico City to Tehuantepec, are the first naturalists who ever collected birds for scientific purposes in Mexico.

The following itinerary has been compiled from Deppe's letters, kept in the archives of the Zoological Museum in Berlin, and from the entries in Lichtenstein's lists of acquisitions.

From 25 December 1824, to January 1825, an excursion was made from Alvarado (NE-15, 19-96d) to the swamps and lagunas near Tlacotalpán (NE-15, 19-96d) in Veracruz. In January he went from Alvarado to Jalapa (NE-14, 20-97d), Veracruz, and in February from Jalapa to Mexico City (NE-14, 19-99a).

In April an excursion was made from Mexico City to Temascaltepec (NE-14, 19-100a), State of Mexico, where Deppe made the acquaintance of Mr. Bullock Jr., who, like his father, took the hobby of collecting birds and was an excellent shot. He had came over with his father in 1823 and lived in Temascaltepec as an agent of a British mining company. Deppe went back to Mexico City on 10 May. He stayed in and near Mexico City from 11 May to the end of the month.

In June and July a trip was made to Chico (NE-14, 19-97b) and Toluca (NE-14,20-97c) in the State of Mexico, including a stay at Tlalpujahua (NE-14,20-100c) and another at Cimapán (?).

On 25 August. Deppe, joined by Bullock Jr., started for a long voyage to Tehuantepec. Taking the route via puebla (NE-14, 19-98a) and Tehuacán (NE-14, 18-97a) they reached the city of Oaxaca (NE-14, 17-96d) by 6 September. Extensive field work was done in the vicinity. On one of these trips they reached Villa Alta (NE-14, 17-96a) '37 legoas' from Oaxaca on 22 September.

On 22 October Deppe and Bullock continued their journeys, and six days later they reached Tehuantepec (NE-15, 16-95a) via San Bartolo (NE-14,17-97d). Early in November they proceeded to the Pacific shore (San Mateo del Mar. Santa Maria del Mar (NE-15, 16-95b) and were back at the city of Oaxaca (NE-14, 17-96d) by the 22nd of that month.

On 5 December, Bullock left for Mexico City to meet his father. Deppe left Oaxaca (NE-14, 17-96d) the next day and chose a direct route to Alvarado which proved very difficult. On 18 December, he crossed the Cordillera Costal at a place called Valle Real (?). Veracruz, clad with luxuriant forest. He was back in Alvarado (NE-15, 19-96d) on 22 December. 
Early in January of 1826 Deppe paid another, and this time extensive, visit to Valle Real. From there he returned to Alvarado in March and proceeded via Santuario to the city of Veracruz (NE-14, k9-96a), which was reached by 23 March. After a short stay he left for Mexico City (NE-14, 19-99a) at the end of March. The time from 13 April to 16 July was devoted to excursions to the environs of Mexico City, including a trip to Chico (NE-14, 19-97b) and Ixmiquilpec (?).

On 17 July Deppe left the capital to visit his friend Bullock Jr., at his place in Rincón de Temascaltepec (NE-14, 19-100a). He crossed the range of Las Cruces and proceeded via Tenancingo (NE-14, 19-100d) and Saculpán (?). México. His stay in Temascaltepec (NE-14, 10-100a) lasted from 28 July to late September, with excursions to Real (de) Arriba (?). México, and to Jantepeque (?) and Cuernavaca (NE-14, 19-99c) in Morelos.

In August in Temascaltepec Deppe met William Bullock, who had made a business voyage to Mexico in company of his wife and daughter. After his return to London in 1823 the senior Bullock founded a British mining company of which he was the director.

At the end of September. Deppe went back to the Federal Capital and prepared for a quick departure. He reached Jalapa (NE-14, 20-97d) by 26 October and embarked at Veracruz (NE-14, 19-96a) at the end of January for Hamburg on the German vessel 'Anna Maria'. On 9 April 1827, after almost three years of absence, he was welcomed back to Berlin.

Since the landing at Alvarado in December 1824, there has been no mention of the Count von Sack in this short review of the itinerary. The Count seems to have been a very queer and whimsical person. No longer disposed to suffer his employer's bad manners. Deppe parted company with him in May of 1825 and carried out all the rest of the expedition at his own risk. The Count returned to the coast in the autumn of 1825 . sailed back to Jamaica, and reappeared in the summer of 1826 in Berlin. where three years later he died.

In the years 1825 and 1826. Deppe had gathered, all by himself, 958 bird skins, a number of mammals, a quantity of reptiles. amphibians. fishes, snails, and thousands of insectts. Nor had botany been neglected by this indefatigable naturalist. All his zoological material was bought by the Zoological Museum of Berlin. But in vain had be hoped to be rewarded with a post at one of the scientific institutions of the Prussian capital. This induced hirn to return to his beloved Mexico once more. this time 
in the company of a dear friend, the botanist Dr.Wilhelm Schiede. They expected to make their living in Mexico by selling zoological and botanical specimens to European museums and dealers.

In July of 1828 they settled in Jalapa, whence they made distant excursions to various places, all within or near the boundary of the State of Veracruz; among others were the Pico de Orizaba (NE-14, 19-97a), which they ascended almost to the summit, Misantla (NE-14, 20-97d), Papantla (NE-14, 20-97a). Veracruz (NE-14, 19-96a), and the Laguna Huetulacán (?). west of the Cofre de Perote (NE-14, 19-97a). But they were very soon disappointed. Lichtenstein was no longer able to buy quantities of Mexican materials at reasonable prices, and although part of the specimens collected up to 7 May 1829, was been acquired by the Museums of Berlin and Vienna, the financial result of their efforts was far from what they had expected. Ferdinand Deppe and Schiede were forced to give up this kind of business in 1830. The latter died very soon afterward. Deppe became a commission agent to merchants located in Acapulco and Monterey. California. In 1836 he was tricked out of all he had earned and decided to sail home to Germany once more. Back in Berlin in 1838, the unfortunate Deppe was again denied an official appointement. He died in oblivion about 1860 (Stresemann, 1954).

\section{Hornbeck}

HANS BALTZAR (or Balthasar) HoRNBECK was born on 9 January 1800, in Copenhagen. He studied medicine, and went to St. Jean, in the Lesser Antilles, in 1825 as a medical doctor. There he became district doctor and in 1827 the official physician for the Danish West Indies. He collected plants and other natural history specimens, especially in St. Jean (NE-10, 18-65b). but also in St. Thomas (NE-20, 18-65b). St. Croix (NE-20, 18-65d) and Puerto Rico. In 1844 he returned to Copenhagen. bringing with him a collection of insects, which was sold by auction after his death. which occurred at the Copenhagen Hospital (Kobenharns Sygehjem) on 2 February 1870. Part of his collections (the beetles) was later incorporated to the Zoological Museum of Copenhagen, but the fate of the rest is not known. As regards the Diptera of Dr. Hornbeck in Westermann's collections, the type-specimens have been lost, but specimens determined by Wiedemann still exist there (Urban, 1903: 61: Zimsen. 1954: 7). 


\section{ESSAYS ON THE HISTORY OF NEOTROPICAL DIPTEROLOGY}

Wiedemann makes special and repeated references to the Island of Crabs (Vieques) in Puerto Rico, which seems to have been the preferred spot where Hornbeck collected.

\section{References}

Stresemann, E.

1954. Ferdinand Deppe's travels in Mexico, 1824-1829. The Condor 56 (2) : 86-92.

Urban, I.

1903. Notae biographicae peregrinatorum Indiae occidentalis botanicorum. in his Symbolae Antillanae 3 (1) : 14.158. Lipsiae (= Leipzig).

Zimsen. E

1954. The insect types of C. R. W. Wiedemann in the Zoological Museum in Copenhagen. Spolia Zool. Mus. Hauniensis 14: 1-43. 


\section{Thunberg, Erichson, Perty and Wiedemann}

K. P. Thunberg

The chair of botany of the University of Uppsala was left vacant due to the death of Linnaeus Jr. in 1784. Karl Peter Thunberg was nominated to take the position. He was born in Joenkoepping. Province of Smaaland, Sweden, on 11 November 1743, and studied at the University of Uppsala under Linnaeus. As a medical doctor, the entered the employ of the Company of the East Indies and was sent in 1772 to the Cape of Good Hope, where, for approximately three years, he collected many specimens during his excursions, and visited the Hottentots and Kaffirs. In 1775 , also as a Company physician, he travelled to Japan, returning to the Cape in 1778 . From there he returned to his homeland, having been appointed teacher at the University of Uppsala to replace Carl Linnaeus Jr. He donated his collections to the University and transformed the ancient Royal Gardens of Uppsala into botanical gardens, which were inaugurated on 4 May 1807, at the occasion of the first centenary of the birth of Linnaeus. Thunberg died on $\delta$ August 1828 (Enc.).

Although better known as a botanist. Thunberg wrote many entomological papers. Due to his acquaintance with the General Consul of Sweden and Norway in Brazil. Lorentz Westin, and with the naturalist Wilhelm Freyreiss, whom he had met in 
Uppsala, Thunberg received some insects from Brazil; he described the two largest Diptera, one a Mydas (1818), and the other the first Pantophthalmid (1822), collected by Forsström in St. Barthélemy.

\section{W. F. Erichson}

Wilhelm Ferdinand Erichson was born on 26 November 1809, in Stralsund, the eldest son of Senator Erichson. His first studies were made in the local gymnasium, which he left to enter the University of Stettin, in October 1828. After four years of study he became a medical doctor, publishing his doctoral dissertation on 7 December 1832. After passing the habilitation examinations of the State he became a doctor in medicine and surgery, on 14 April 1834. Even as a student, he dedicated some time to building an entomological collection, which would be the basis of his future writings. In 1836 he began to be paid by the Stettin Museum, becoming curator in 1843. He was then already suffering from lung disease, losing blood during the more severe attacks. However, he paid no attention to the illness, which was aggravated through strenous physical and intellectual effort. In 1837 he was made Doctor Philosophiae by the University of Jena. He was appointed assistant professor in the Faculty of Philosophy of the Stettin University in May 1838 and extraordinary professor on 21 March 1842. On account of repeated attacks and losses of blood due to his lung disease, he died at the age of 40 on 18 November 1849 (Klug. 1850).

His great contribution to the study of Neotropical Diptera was his revision of the "Henopier" (Acroceridae). published in 1840. Studying the collection of the Museum of Berlin, he revised Wiedemann's types, and described several new species based on the collections presented to the Museum by Baron von Langsdorff (from Minas Gerais, in Brazil, especially). Bescke. Sellow (also from Minas Gerais, especially Sāo Joāo del Rei). Deppe (from Mexico), and collections gathered by a certain VIRMOND, concerning whom we have no information.

\section{J. A. M. Perty}

Joseph Anton Maximilian Perty, was born in Ohrnlau (Duchy of Anspach) in 180\%, and died in 1884; he studied medicine and natural sciences in Landshut and Munich. He joined the Faculty

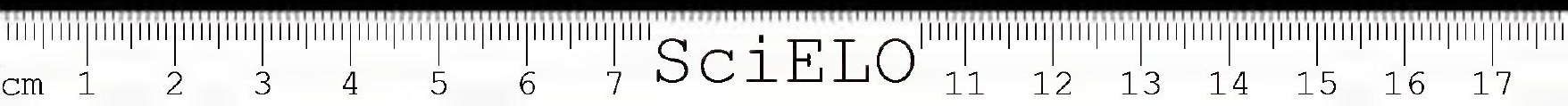


of Sciences of Munich, being charged with the organization of part of the zoological collections of the city's Academy of Sciences. Among the valuable collections existing in the Academy there was that brought home by Drs. Johann Baptist von Spix and Karl Friedrich Philip von Martius, from their long journeys in Brazil, financed by King Maximilian Joseph I. The results of Perty's studies of this collection were published in a large folio. from 1830 to 1833. Several interesting Diptera (as for instance, the first flies collected in the Brazilian "caatingas" of the Northeast) were reported in that book.

In 1833 Perty was named Professor of the Academy of Berne, Switzerland, transferred to the University in the next year, and was the Dean of the University from 1837 to 1856 . He also wrote many other books on zoology. especially on microscopic animals, anthropology and psychology (Enc.).

\section{R. W. Wiedemann}

Christian Rudolph Wilhelm Wiedemann, one of the greatest dipterologists who studied the Neotropical fauna, was born in Braunschweig in 1770 and died in 1840 in Kiel, at that time part of the Danish Duchy of Holstein. He obtained his degree of Doctor Medicinae in Jena in 1792, and in 1805 was made successively professor of obstetrics at the University of Kiel, and professor, later director, of the School of Midwifery. Eventually he became "Justitsraad".

His medical publications include a book on anatomy (1796). a manual for resuscitating the drowned and asphyxiated (1797). and one with instructions for midwives (Enc.).

He very soon became interested in the study of Diptera, and was strongly influenced by the great master. Meigen. his contemporary. From 1800 to 1806 he edited the "Archiv für Zoologie und Zootomie" (5 volumes). and from 1817 to 1825 the "Zoologisches Magazin" (2 volumes), where he published his first articles on Diptera.

Through Count von Hoffmannsegg he obtained the Diptera collected in Brazil by Sieber. Gomes, and Feijo, and these were the subject of his first paper on Brazilian flies (1819). (It is not known whether Wiedemann also studied materials from Hoffmannsegg's collections collected by Ruiz and Pavón, but a label of Hoffmannsegg's collection, from the Berlin Museum. which came with a collection of Pyrophorus loaned to my collea- 


\section{ESSAYS ON THE HISTORY OF NEOTROPICAL DIPTEROLOGY}

gue C. Costa, gave indication of material collected by the two Spanish naturalists).

Wiedemann, after this start, decided to undertake a thorough study of the exotic Diptera, thus complementing the work that Meigen was doing for the European flies. Wiedemann's initial intention was to redescribe the species of Fabricius. The latter's collection, which was in a very poor state of preservation. had been transferred by the King of Denmark to the University of Kiel. Wiedemann revised the entire work of Fabricius. making a better generic assigment of the species, and redescribing most of them. Fabricius' descriptions were very inadaquate, and even the names of colours employed by him had to be deciphered. Wiedemann built a glossary of colour names and morphological terms employed by Fabricius, which was printed in the first volume of the "Aussereuropäische zweiflügelige Insekten" (1828: xxiii-xxvii).

This work appeared first in Latin, in 1821; it was afterwards translated into German, and appeared in a much enlarged two volume edition $(1828,1830)$. In 1824 Wiedemann published an "Analecta Entomologica", with new species of flies, later embodied in the "Aussereuropäische zweiflügelige Insekten".

For his descriptive work, Wiedemann had access to the great collections of the time, deposited in the Museums of Berlin, Leyden. Frankfurt, Copenhagen, and in private collections, such as Westermann's, Winthem's, and Prince Christian of Denmark's (later King Christian VIII).

Those collections included the rich harvests reaped by Humboldt and Bonpland in Venezuela, Colombia. Ecuador, Peru, and Mexico: Eschscholtz's collections made in Brazil (Santa Catarina) and Chile; by Sieber, Gomes, and Feijó in Brazil (Amazonian region. Ceará. Pernambuco, and Bahia) : by Freyreiss and Westin. von Olfers, Sellow, Bescke, and Lund, in Brazil; by Deppe in Mexico; and by Hornbeck in the West Indies (cf. Fairchild. 1967). He also discovered many new species, even among Fabricius' specimens. Wiedemann also had many specimens of flies from Surinam: part of these was obtained from the collection of a certain Holthuysen. sold by auction at Hamburg, on 3 February 1796 (Weidner, 1967: 43). and part from a collector named Cordua (?), about whom we were not able to obtain any detail. Another unknown collector is Virmond. cited above, who collected in Brazil (material in the Berlin Museum;

News of the recent Austrian expedition to Brazil also reached Wiedemann, and he wrote to $\mathrm{M}$. von Mühlfeld, at the lmperial Museum of Vienna, trying to borrow the specimens. But to his 
disappointment, Wiedemann was informed that the Austrian Emperor had forbidden him to study the specimens, which had been collected at the expenses of the Austrian Crown. Wondering at that order. Wiedemann applied directly to the Emperor, saying that the specimens would be returned, after being studied, in perfect conditions. The answer, however, was again negative, and Wiedemann complained bitterly about this incident in the introduction of his great work (1828: v): "May God forgive those who have given such advice! My concern was only with science. Now I can do no more than wish that some future describer of the Diptera in Vienna might recognize the species from my descriptions and synonymy might be avoided." (Translated by G. C. Steyskal).

Wiedemann was not able either to study the collections of the Museums of London and Paris, for lack of money to travel to those countries.

His work was one of the best of the older authors, in spite of the unavoidable shortcomings, and still remains one of the basic books for the taxonomy of Neotropical Diptera (Henriksen. 1921-37: Zimsen, 1954).

\section{References}

Fairchild. G. B.

1967. Notes on Neotropical Tabanidae (Diptera). VII. The species described by C. R. W. Wiedemann. Pacific Insects 9 (1) : 73-104.

Henrikscn, K. L.

1921-1937. Oversigt over Dansk entomologis historiae. Ent. Meddel. 15 (1) $(1921): 1-48 ;$ (2) (1922) : 49-96; (3) (1923) : 97-144: (4) $(1925): 145-192:$ (5) (1926): 193-240; (6) (1927) : 24125s: $(7-8)$ (1936) : 289-384: (9-10) (1936) : 385-480; (11-12) (1937) : 451-578: 154 figs.

Erichson. IV. F.

1840. IV. Dic Henopicr, cine Familie aus der Ordnung der Dipteren. pp. 135-175. 1 pl. in his Entomographicn. Untersuchungen in dem Gebiete der Entomologie mit besonderer Benutzung der Koonnigl. Sammlung zu Berlin I : 180 pp., 2 pls. Berlin.

Klug. $F$.

1850. Nekrolog [W. F. Erichson]. Stcttin. Ent. Ztg. 11 (2) : 33-36. 


\section{ESSAYS ON THE HISTORY OF NEOTROPICAL DIPTEROLOGY}

Perty, J. A. M.

1830-1833. Delectus animalium articulatorum, quae in itinere per Brasiliam annis MDCCCXVII-MDCCCXX jussu et auspiciis Maximiliani Josephi I. Bavariae regis augustissimi peracto collegerunt Dr. J. B. de Spix et Dr. C. F. Ph. de Martius, $44+224$ pp., 40 pls. Monachii (= Munich). (Pp. 1-60, pls. 1-12, 1830; pp. 61-124, pls. 13-24, 1832; pp. 125-224, pls. 25-40, 1833). "1830-1834".

Thunberg, C. P.

1818. Mydas gigantea beskrifven. Vetensk. Akad. Handl. 181S : $246-248$

1822. Beskrifning paa en ny Insect, Pantophthalmus tabaninus. Götteborgs Kongl. Vettensk. och Vitterhets Samhällets Handl. $3: 7$.

Weidner, $\mathrm{H}$.

1967. Geschichte der Entomologic in Hamburg. Abh. Verh. Naturuiss. Ver. Hamburg (N.F.) 9 (suppl.) : 1-387, illus.

Wiedemann, C. R. W.

1819. Brasilianische Zweiflügler. Zool. Mag. 1 (3) : 40-56.

1821. Diptera exotica 1 : 19-244 pp. 2 pls. Kiliae (= Kiel).

1824. Munus rectoris in Academia Christiana Albertina aditurus analecta entomologica ex Museo Regio Hauniensi, 60 pp. 1 pl. Kíliae $(=\mathrm{Kiel})$.

1828. Aussercuropäische zu'eiflügelige Insekten 1 : xxxul +608 pp. 7 pls. Hamm.

1839. Aussereuropāische zweiflütugelige Insekter $2: \mathrm{xI}+6 S t$ pp., 5 pls. Hamm.

1831. Monographia generis Midarum. Nova Acta Acad. C. Lcopold. Carol. Nat. Curios. 15 ([= ser. 2 (5) (= Verhandl. 7) (2)] : 19-56, p15. $52-54$.

Zimsen, E.

1954. The insect types of C R. W. Wiedemann in the Zoological Muscum in Copenhagen. Spolia Zool. Mus. Hauniensis 14: $1-\{3$. 
Chapter VIII

\section{The French collectors}

\section{Saint-Hilaire}

Augustin François César Provençal de Saint-Hilaire was born in Orléans. France, on 4 October 1779 , and died in the same city on 30 September 1853. His parents had destined him to commerce, and with that purpose made him travel through Holland and Holstein. However, after his return to France he dedicated himself to botany.

On 1 April 1816, he sailed from the port of Brest, France, aboard the frigate 'L'Hermione', which carried to Rio de Janeiro the Ambassador of France, Duke of Luxembourg. After the customary stops in Lisbon, Madeira and Teneriffe, they arrived to Rio on 1 June 1816.

Saint-Hilaire was also accompannied by another naturalist - Pierre Antoine Delalande. Delalande was born in Versailles in 1787, and died in 1828. In his earliest years he studied painting. and when he was 13 was employed by his father as technician in the laboratory of zoology and ornithology of the Muséum d'Histoire Naturelle of Paris. Having been excused from entering the army by Napoleon, he travelled through the French 'Midi', Spain, and Portugal (1808). Having probably met Saint-Hilaire at the Museum, he came with him to Brazil in 1816. He returned to France after a short voyage through the Province of 
Rio de Janeiro, carrying the collections obtained. He travelled later to Africa (1818-1819), and has been better known by his trip to the Cape of Good Hope, about which he published a report in the Mémoires du Muséum d'Histotire Naturelle de Paris, vol. 8 (Enc.).

The first journey undertaken by Saint-Hilaire, accompanied by Delalande, was to a farm of a certain J. Rodrigues de Almeida in Rio de Janeiro. The two naturalists also collected in and near the city.

The remaining journeys will be arranged here partly according to Saint-Hilaire's books, and partly according to the citations given in the works of Robineau-Desvoidy and Macquart.

1. Journey to the Province of Rio de Janeiro ("Rio-Janeiro. M. Aug. Saint-Hilaire", and "Brésil. Delalande", of Macquart)

Crossing the Bay of Guanabara. Saint-Hilaire and Delalande entered the small Rio Miriti (near the present city of São João do Meriti. SF-23, 43-23a), and proceeded past Iguassu (now Nova Iguaçu, SF-23, 44-23b). Benfica (?). Rio Itu (?). Vale das Pedras (?) (where they were in the beginning of December. 1816). Serra da Viúva (?). Pau Grande (?). and Ubá (SF-23. 43-22c). near the banks of the Rio Paraiba, approximately 25-30 leagues NNW of Rio de Janeiro, where they made a large collection of insects. They visited on that occasion a village of the Coroado Indians, and returned by the same route to Rio de Janeiro. After this rapid trip. Delalande went back to France with the collections, and Saint-Hilaire started a second trip.

2. Trip to the Province (or 'Capitania") of Minas Gerais ("Capitainerie des Mines" of Macquart)

Leaving Rio de Janeiro on 7 December 1816. Saint-Hilaire went to Minas Gerais by the invitation of Antonio Ildefonso Gomes, a resident of that Province. They were accompanied by Baron von Langsdorff, who had made the acquaintance of Saint-Hilaire in Rio. Passing through São Cristóvāo (in the neighborhood of the city of Rio de Janeiro). Inhauma. Iguassu (Nova Iguaçu. SF-23. 44-23b). Benfica. Ubá (SF-23, 43-22c) and Encruzilhada ( $S F-23,43-22 \mathrm{c}$ ), the party arrived at the banks of the Rio Paraiba, and entered Minas Gerais, following the itinerary: Rio Paraibuna, Rocinha da Negra, Vargem. Simào Pereira (SF-23. 43-22a). Matias Barbosa (SF-23,43-22a). Juiz de Fora (SF-23, 43-22a). Chapéu d'Uvas (SF-23, 44-22b). Retiro, across the Serra da Mantiqueira. Borda do Campo, Barbacena (SF-23. 
44-21d), Queluz (Queluzita, SF-23, 44-21b), Ouro Branco (SF-23, 44-21b), and Vila Rica (Ouro Prêto, SF-23, 44-20d).

In Vila Rica the naturalists stayed at the house of Baron von Eschwege, until 26 December 1816. There A. I. Gomes left the party to visit his family in São Miguel do Mato Dentro.

Proceeding with the trip. Saint-Hilaire and Langsdorff went to Mariana (SF-23, 43-20a), Camargos (SF-23, 43-20c), Bento Rodrigues (SF-23,43-20c). Serra do Caraça (in the county of Santa Bảrbara, SF-23, 43-20a). Inficionado, Morro de Água Quente. Catas Altas de Mato Dentro (now Catas Altas, SF-23. 43-20c). and Itajuru, then returned to Serra do Caraça. At this Doint Baron von Langsdorff left the party and went back to Rio de Janeiro. Saint-Hilaire continued by himself through Itabira (SE-23, 43-20a) to visit the mines of Conceição (de Piracicaba, SE-23. 43-20a), south of Itabira, going afterwards to Santana (SE-23,43-20a). Itambé do Mato (de) Dentro (SE-23, 43-19c). Morro de Gaspar Soares (presently Morro do Pilar, SE-23, 43$-19 c$ ). Conceição de Mato Dentro (Conceição, SE-23, 43-20b). 'Tapanhuacanga' (Itapanhoacanga, SE-23, 43-19a). Rancho do Ouro Fino, near the Ouro Fino creek (SE-23, 44-19b). Vila do Principe (Sêrro, SE-23, 43-19a), leaving that village on 9 April 1817.

Next he proceeded to 'Passanha' (Peçanha, on the banks of the Rio Suaçui, SE-23, 43-19b), which they left on 21 April. Ponte dos Paulistas (Paulistas, SE-23, 43-18d). Rio Vermelho. Penha (Penha de França, SE-23. 43-18d). Sāo Joāo Batista (now Itamarandiba, SE-23, 43-18b). Vila do Fanado (Minas Novas. SE-23. 43-17d). Chapada, Sucuriủ (now Francisco Badaró, SE-23, 42-17c), São Miguel da Sétima Divisão (presently Jequitinhonha, SE-24,41-16d), near the Rio Jequitinhonha.

From the village of São Miguel Saint-Hilaire went down the Rio Jequitinhonha to the Ilha do Pão and Canal do Vigia, returning next to Säo Miguel. Leaving this village on 15 July 1817, he journeyed overland by way of Sucuriu. Virgem da Lapa (Sảo Domingos, SE-23, 43-22b), Chapada (SE-23, 42-17c), Vila do Fanado (Minas Novas, SE-23, 44-18d). Vereda. Säo Joäo Batista (Itamarandiba, SE-23, 43-18b), and, turning to the NW. to Itacambira (SE-23, 43-17c). Montes Claros (SE-23, 44-17a). and Contendas (Brasilia de Minas, SE-23,44-16c), to the Rio Säo Francisco. Then, travelling south, he went through Coração de Jesus (SE-23, 44-17a), to Curimatai (SE-23, 44-18b) (Saint-Hilaire, 1830. 1938b).

Leaving Curimatai on 22 September 1817, he went through Sāo Joảo da Chapada (?). Pinheiros (SE-23, 44-18d: 29 Septem- 
ber) to Tejuco (Diamantina, SE-23, 44-18d), where he remained until 30 October, collecting in the neighborhood.

From Diamantina he journeyed to Milho Verde (?). Três Barras (?). Vila do Principe (now Sêrro, SE-23, 43-19a), Itapanhoacanga (SE-23, 43-19a). Santo Antônio do Norte, Congonhas do Norte. Morro do Pilar (SE-23, 43-19c; 19 November. 1817). Itambé do Mato (de) Dentro (SE-23, 43-19c). Cocais, Santa Bárbara (SE-23, 43-20a). Serra do Caraça, Sabará (SE-23. 44-20b). Ouro Prêto (SF-23, 44-20d). Congonhas (SF-23, 44-20d: 13 February. 1918). São Brás do Suaçui, Lagoa Dourada. and São João del Rei (SE-23, 44-21c), proceeding directly to Rio de Janeiro, where he arrived on 17 March 1818.

As a result of this journey. Saint-Hilaire sent to the Museum of Paris 3 boxes with zoological collections, among which were 800 species of insects, 200 birds and mammals, 200 packets of seeds and severals memoirs on botany. During his stay in Rio de Janeiro he met several members of the Austrian commission. recently arrived, among them Olfers. Mikan. Pohl, and Raddi.

\section{Trip to the Province of Espirito Santo}

Having mailed the collection obtained in Minas Gerais, Saint-Hilaire decided to go to Espirito Santo. Leaving Rio de Janeiro on 18 August 1818, he went by sea to Cabo Frio (SF-24. 42-23b), where he landed. From Cabo Frio he visited Saao Pedro da Aldeia (SF-23, 42-23a), and following the coast, went to Macaé (SF-24, 42-22d) and São João da Barra (SF-24, 41-22a). near the mouth of the Rio Paraiba. He next proceeded to Campos dos Goitacazes (Campos, SF-24, 41-22a), and to the mouth of the Rio Muribeca, entering the Province of Espirito Santo at Itabapoana (SF-24, 41-21d). Travelling along the coast, he went through Itapemirim (SF-24, 41-21d), which he left on 4 October, Benevente (presently Anchieta, SF-24, 41-21b), Guarapari (SF-24, 40-21a), and arrived at the Capital of the Province, Vitória (SF-24, 40-20c) on 10 October 1818.

From Vitoria, still following the coast, Saint-Hilaire went through Vila d'Almeida (now Nova Almeida, SF-24, 40-20c). near the Rio dos Reis Magos (16 October). Aracruz (SE-24. 40-20a). Campos do Riacho (Riacho, SE-24, 40-20a), and reached the mouth of the Rio Doce, in the village of Regência (SE-24. 40-20b). Travelling up the Rio Doce (SE-24, 40-19d) by canoe, he arrived at the city of Linhares (SE-24, 40-19c) on 22 October. He entered the Lagoa Juparana (SE-24, 40-19c) through the canal which communicates with the Rio Doce, and then returned to 


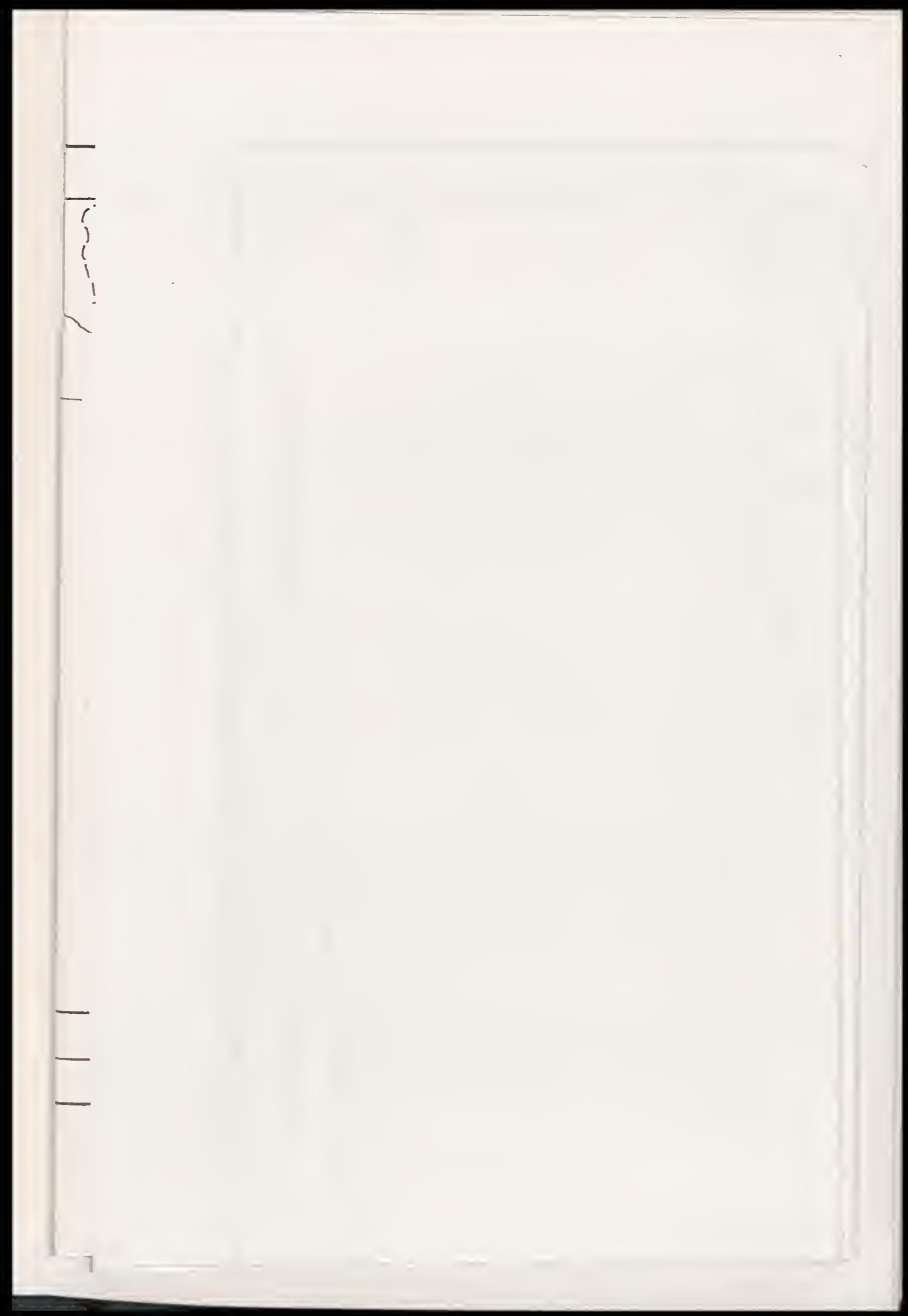




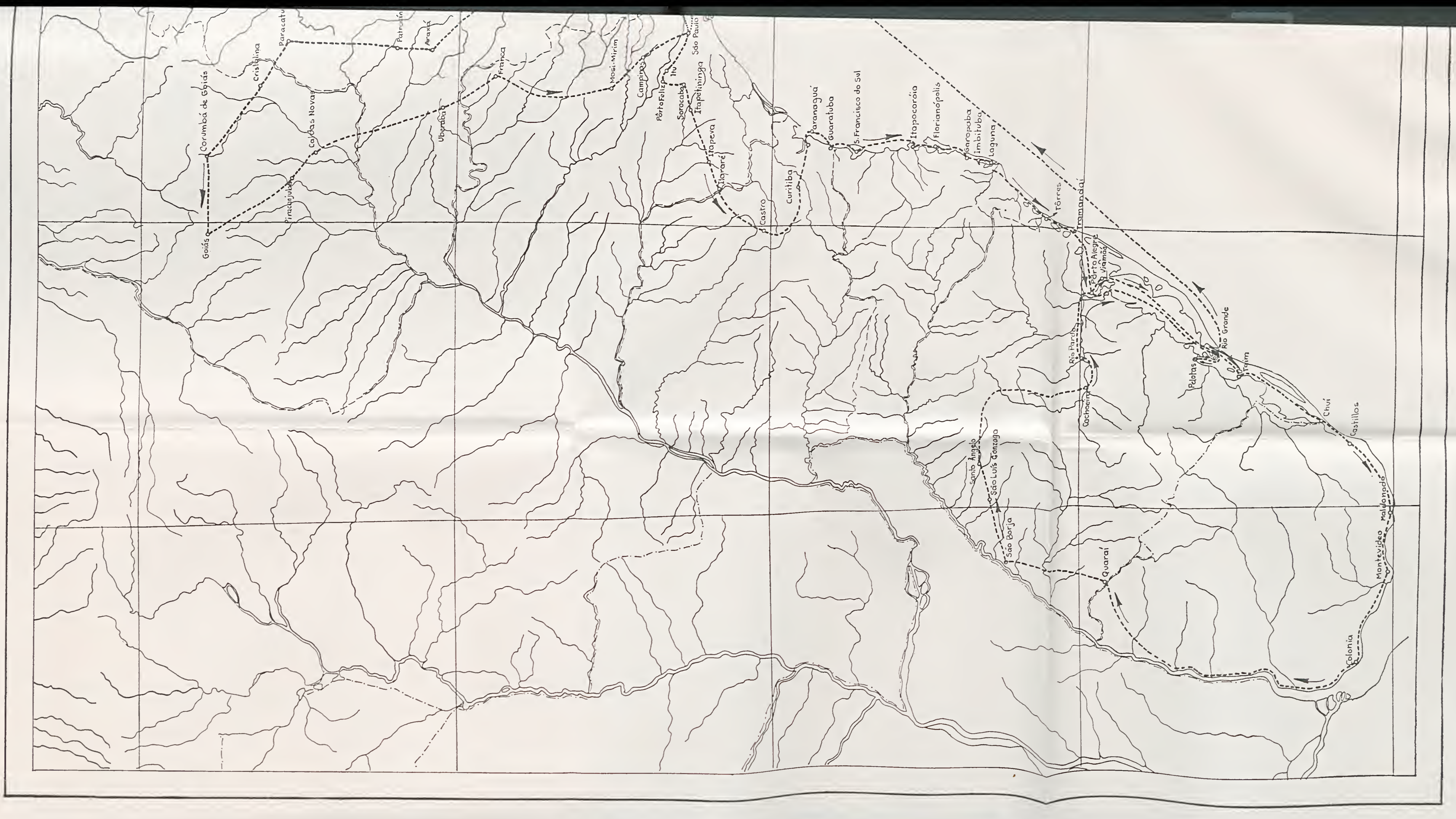

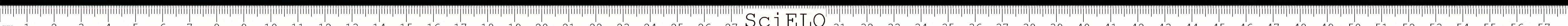




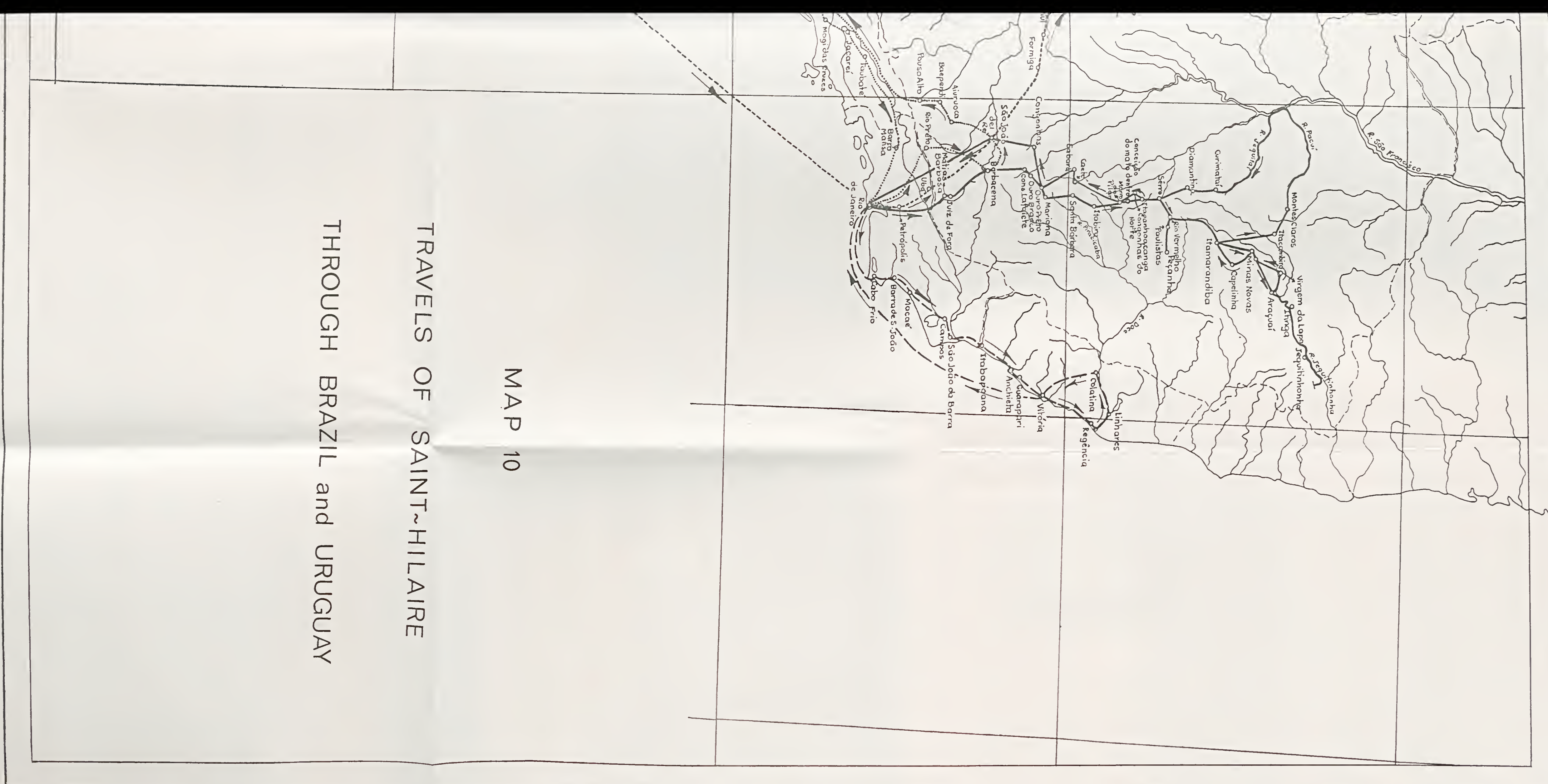

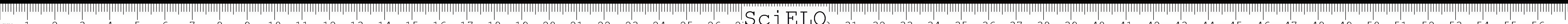


Linhares. Proceeding down the Rio Doce. Saint-Hilaire went back to Regência, and travelling overland, along the coast by Ponte dos Comboios (now Comboios, SE-24, 40-20b), and Vila d'Almeida (November 1), he arrived in Vitoria, from which he sailed to Rio de Janeiro, arriving after a 4 days trip (Saint-Hilaire, 1838, 1936b, 1941).

Back in Rio de Janeiro, he made a third shipment of the collections to the Paris Museum, keeping however a part of them, left with Mr. Maller, General Consul of France in Rio.

4. Second trip to Minas Gerais ("Capitainerie des Mines, Ouest" of Macquart), and voyage to Goiás ("Centre du Brésil" of Robineau-Desvoidy).

On 26 January 1819, Saint-Hilaire left Rio for a third voyage to the interior of the country. Leaving the Bay of Guanabara, he entered the Rio Inhomirim, to Pôrto da Estrêla. Thence he went to the Farm "Mandioca" of Baron von Langsdorff, where every naturalist of the time collected. Going on afterwards via Petrópolis (SF-23, 43-23a). Sumidouro (SF-23, 43-22d). Encruzilhada, Sucupira, and Ubá (SE-23, 43-22c), he arrived at the banks of the Rio Paraiba, proceeding to Forquilha (SF-23, 43-22b). Rio das Flores (SF-23, 44-22b). Valença (SF-23, 44-22b). Rio Bonito (SF-23, 43-23b), and arriving at the city of Rio Prêto $(\mathrm{SF}-23,43-22 \mathrm{c})$, on the banks of the river of the same name at the border between the Provinces of Rio de Janeiro and Minas Gerais.

Entering Minas, he headed for Sāo João del Rei (SF-23, $44-21 c)$, and went on to Oliveira (SF-23,45-21b). Formigas (SF-23, 45120c). Córrego Fundo, Pains (SF-23, 46-20d), Pimenta (SF-23, 46-20d). Piui (SF-23,46-20d), and Serra da Canastra (SF-23, $47-19 c$ ). where he explored the sources of the Rio Sāo Francisco. He proceeded then to Araxá (SE-23, 47-20b), crossed the Rio Quebra-Anzol (SE-23, 47-17c), and continued through Patrocinio (SE-23, 47-19a), Guarda-Mor (SE-23, 47$-18 \mathrm{a})$, and Paracatu (SE-23, 47-17d).

From Paracatu, turning to the NW, Saint-Hilaire entered the Province of Goias, going through Cristalina (SE-23, 48-17b). and after crossing the Montes Pirineus reached Corumbá (Corumbá de Goiảs, Brasilia. D.F., SD-22, 49-16b), and Vila Boa, capital of the Province (the city of Goiás, SD-22, 50-16a). After remaining there for some time, he departed on 3 July 1819 , going to Sảo Josẻ de Mossâmedes (Mossâmedes, SE-22, 50-16r) and Pilöes (SE-22, 51-16d), on the Rio Claro, returning later to Vila Boa (Saint-Hilaire, 1847, 1845, 1937). 
Saint-Hilaire decided then to proceed to the Province of São Paulo; leaving Vila Boa he passed the Rio Uru. Piracanjuba (SE-22, 49-17c), Caldas Novas (SE-22, 49-18b), crossed the Rio Paranaiba, entering the Province of Minas Gerais, and through Uberaba (SE-23, 48-20b), crossing the Rio Grande, entered the Province of São Paulo.

5. Trip through the northern part of the Province of São Paulo ("Nord de la Capitainerie de St. Paul" of Macquart)

Entering the Province of Sāo Paulo (which included at the time the present States of São Paulo and Paraná). Saint-Hilaire proceeded by Franca (SF-23, 47-21a). Mogi-Mirim (SF-23. 47-22d). Campinas (SF-23, 47-23a), and Jundiai (SF-23, 47$-23 a)$. and reached the city of São Paulo, where he remained from 1 November to 9 December 1819. His collections, gathered in the Provinces of Minas Gerais. Goiass, and in the northern portion of São Paulo, were left in the Capital.

Leaving São Paulo (SF-23, 47-24b). Saint-Hilaire went to Itu (SF-23,47-23c), Pôrto Feliz (SF-23, 47-23c). Sorocaba (SF-23. 47-24a), and Ipanema (Varnhagen), where he arrived on 22 December 1819. meeting Johann Natterer and Friedrich Sellow, who were stationed there.

6. Trip to the 'Comarca de Curitiba' (present State of Paraná). and to the Province of Santa Catarina.

Departing from Ipanema. Saint-Hilaire returned to Sorocaba (SE-23, 47-24a), and passed through Itapetininga (SF-22, 4822a). Itapeva (SF-22, 49-24b), and Itarare (SF-22, 50-24b). then entering the present State of Paraná by Jaguariaiva (SG-22. 50-24d). Castro (SG-22, 50-25a), and Ponta Grossa (SG-22. $50-25 d, 50-25 c)$, he arrived at Curitiba (SG-22, 49-25c). During that trip. which lasted three months, he had enormous difficulties in keeping his collections of natural history. due to the incessant rains.

From Curitiba he went down the Serra de Paranagua to the city of Paranaguá (SG-22, 48-26a). following the coast to Guaratuba (SG-22, 49-26b), where he collected many Diptera, described afterwards by Robineau-Desvoidy and Macquart.

He then sailed to the Island of Sāo Francisco. landing in the village of Sāo Francisco do Sul (SG-22, 45-26a). He remained there until 21 April 1820, and sailed next to Barra do Araguari, going overland to Barra Velha and Itapocoroia (SG-22. 49-27b). Again by sea, passing by Itajai (SG-22, 49-27b). Ca- 
beçudas (SG-22, 49-27b), Camboriú (SG-22, 49-27d), and the small islands of Galés. Deserta, and Arvoredo, he landed in the Capital of the Province, the city of Desterro (presently Florianópolis, SG-22, 48-28a).

Leaving Desterro on 18 May 1820, he sailed to Garopaba (SH-22, 49-28d). He obtained three large ox-carts to travel by land, and leaving that city on 21 May. headed for Laguna ( $\mathrm{SH}-22,49-28 \mathrm{~d}$ ). Following the beaches, after crossing the rivers Urussanga. Araranguá, and Mambituba, he entered the Province of Rio Grande de São Pedro do Sul (presently the State of Rio Grande do Sul) (Saint-Hilaire, 1851, 1936a, 1940).

7. Trip through Rio Grande do Sul ("Capitainerie de Rio-Grande", or "Rio Grande" of Robineau-Destoidy and Macquart)

The first city reached by Saint-Hilaire in Rio Grande do Sul was Tôres (SH-22, 50-29d), near the border with Santa Catarina, on 5 June 1820. Proceeding afterwards to the Lagoa Itapeva (SH-22, 50-30a) (7 June), and Tramandai (SH-22, 50-30a; 11 June), he turned west, by Viamão (20 June), and arrived at the Capital. Pôrto Alegre (SH-22, 51-30c), remaining there from 6 August to 4 October 1820. He then visited the city of Pelotas (SH-22,52-32a), near the river of the same name and returned to the city of Rio Grande on 13 October.

Proceeding by way of Taim (SI-22, 53-33b), on the banks of the Lagoa Mirim (SI-22, 33b), he went by land between the Lagoa Mirim and the Lagoa Mangueira (SI-22, 53-33d) to the Arroio Chui, presently the southernmost limit of Brazil (30 October 1820), passing into the Provincia Cisplatina (at that time belonging to Brazil, now the Republic of Uruguay).

8. Trip through Uruguay ("Brésil, Montevideo" of Macquart). and through the western part of the same country ("depuis l'embouchure de l'Uruguay jusquaux Missions" of Macquart)

Entering Uruguay at Angostura (SI-22, 34-54d) (9 November 1820). Saint-Hilaire went on to Castillos (SI-22, 34-54d). where he arrived the next day, and then to Maldonado (SI-21. 35-55b; 19 November), and Montevideo (SI-21, 35-56a), where he arrived 10 days later. From the Capital of Uruguay, he followed the left bank of the Uruguay River, through Colonia (SI-21. $34-58 d$ ). Soriano (SI-21,33-58c). Mercedes (SI-21,33-58c), and Salto (SH-21,31-5Sd), reentering the Province of Rio Grande do Sul in its western portion (at that time called Province of Missōes). on 28 January 1821 . 
9. Trip through the Province of Missōes (Sete Poros das Missões) (now the western part of the State of Rio Grande do Sul; "Brésil. Missions" of Macquart)

Passing through São Borja (SH-21, 56-29b; 19 February; 1821), São Nicolau (SH-21, 55-28c; 9 March). São Luis Gonzaga (SH-21, 55-28; 13 March): Sāo Miguel das Missōes (SH-21, 55-29b: 17 March). Santo Angelo (SH-21, 54-28c; 22 March), Tupanciretã (28 March). Santa Maria (SH-21, 55-30b; 9 April). following the courses of the rivers Vacacai-Mirim (SH-22, 53-30a) and Jacui (SH-22, 53-29a), he reached Cachoeira do Sul (SH-22, 53-30d; 23 April), and the city of Rio Pardo (SH-22, 52-30a; 29 April): sailing down the Rio Jacui he arrived at Pörto Alegre (SH-22, 51-30c).

On 19 June 1821. Saint-Hilaire left Pôrto Alegre, entered the Rio Guaiba (SH-22,51-30c), and sailed the Lagoa dos Patos (SH-22, 51-31a) to the city of Rio Grande (SI-22, 52-32c). whence he finally departed for Rio de Janeiro, arriving there at the end of August 1821 (Saint-Hilaire, 1887, 1939, 1940).

10. Third and last trip to Minas Gerais, and second trip to São Paulo

Saint-Hilaire remained in Rio de Janeiro, revising the collections which had been left there during his latest stay. There were 15 boxes of plants, and 24 of birds, mammals, and insects. He also prepared the collections brought from his trip to Uruguay and Rio Grande do Sul. All the collections were left in the care of an engineer. François Ovide, who had come to Brazil in 1816 with the French Artistic Mission.

On 29 January 1822. Saint-Hilaire left on his last trip. His intention was to go to Sảo Paulo to get the collections left there in 1819. Crossing the Rio Paraibuna on 7 February, he entered Minas Gerais, and collected on several farms along the route, arriving in Barbacena (SF-24, 44-21d) on 19 February. Leaving that city the following day, he reached São João del Rei (SF-23. $44-41 c)$ on the 23rd. Proceeding to the south, by Aiuruoca (SF-23, 45-22b: 5 March), and Santa Maria de Baependi (Baependi. SF-23. 45-22b: 10 March). he crossed the Serra da Mantiqueira, and entered the Province of São Paulo, reaching the city of Guaratinguetá (SF-23, 45-23a) on 23 March 1822. Proceeding by Taubaté (SF-23, 46-23c; 25 March). Jacarei (SF-23, 46-23d; 28 March). Mogi das Cruzes (SF-23, 46-23; 30 March). he arrived at the city of Sảo Paulo (SF-23, 47-24b) on 13 April.

There he obained eight mules to transport his collections (which filled 20 boxes), and left the city on 12 April 1822, fol- 
lowing the usual route to Rio de Janeiro (see trip of Spix $\mathcal{E}$ Martius). He arrived in Rio de Janeiro in the first days of May 1822.

After arranging all his collections, he departed for Europe early in August 1822. In the same year he read to the French scientists a short report of his activities and travels in Brazil; the report was printed in the "Mémoires" of the Paris Museum (1822), and also as a separate booklet (1823).

In 1830 he was received in the 'Académie des Sciences' as a Fellow, in the place of Lamarck, and was appointed professor of botany in the 'Faculté des Sciences' of Paris.

His books of travel were printed in nine volumes. The volume containing the account of his trips through the southern parts of Brazil (Rio Grande do Sul and Uruguay) was published posthumously by de Dreusy in 1887.

Saitt-Hilaire's collections, deposited in the Museum National d'Histoire Naturelle de Paris, comprised 7.000 species of plants (represented by 30.000 specimens). 2.005 bird skins, 16,000 insects, 129 mammals, 35 reptiles, 58 fishes, and other animals (Garcia, 1922; Hoehne, 1942: Sampaio, 1928; Urban, 1908).

Saint Hilaire's specimens had round labels in the pin, either differently colored and/ or with a number. indicating the locality. Samples of these small labels are preserved, and glued to the inside of the binding of the Paris Museum book of accessions ("Catalogue des animaux sans vertebres"). The code is the following:

"blane - Rio-Janeiro et Cape de Rio-Janeiro.

vert - Campos geraés partie mérid. Cape de St. Paul.

brique - des bords de l'Uraguay de puis son embouchure jusqu'aux missions.

brune - Cape de Monte video.

gris - 3 - Province de Monte Video, bords de Rio de la Plata, 7ore 9ise 1820.

noir - Près Rio-Grande de St. Pedro.

1 - de Contenda.

2 - Cape de Rio-Grande.

3 - des Missions.

4 - 2. Province de St. Catherine, bords de la mer mai 1820.

5 - du Nord de la Cape de St. Paul.

6 - du Midi de la Cape de Goyaz.

7 - du midi de la Cape des Mines.

8 - ouest de la Cape des mines.

9 - Cape de Rio-Grande entre les missions et Rio-Pardo." 


\section{Gaudichaud-Beaupré}

Charles Gaudichaud-Beaupré was born on 4 September 1789, in Angoulème, France. He studied pharmaceutics, first with one of his brothers-in-law established in Cognac, and later in Paris, where he also studied botany, under Desfontaines and L. C. Richard. In April 1810, he began his practical career. as "pharmacien de la marine militaire", serving at the ports of Anvers (1811-1814) and Rochefort (1814-1816). His activities as collecting naturalist were displayed on three great sea cruises.

His first voyage was made in the ships 'L'Uranie' and 'La Physicienne", under the command of Captain Louis Freycinet. Louis Claude de Saulses de Freycinet was born in Montélimar in 1779 and died in Freycinet, near Loriol (Drōme), in 1824. He entered the navy in 1794, at the same time as his elder brother. Both participated in several battles in the Mediterranean in 1795 against the united squadrons of Spain and England. In 1800 , both brothers were commissioned to Captain Baudin's expedition to New Holland - Louis Claude embarked in the ' $\mathrm{Na}$ turaliste', while his brother sailed aboard the 'Géographe'. Freycinet returned to France in 1803 . In 1805 he was attached to the cartographic department of the Navy, where he finished the relation of the voyages of the 'Géographe' and the 'Naturaliste', left unfinished by the naturalist Péron, due to his death in 1810 . In 1811 Freycinet was appointed captain of a frigate.

In 1817, the Government having decided to launch an expedition of circumnavigation. Freycinet was given the command of the ship.

The corvette 'L'Uranie' was appointed for the voyage, with a complement of 25 officers. Gaudichaud-Beaupré embarked as naturalist. with the help of the ship's surgeons. JEAx RENE CONSTANTIN QUOY (1790-1869) and JOSEPH PAUL GAIMARD (1790-1858). both also outstanding naturalists. Two artists joined the expedition: J. Arago and Aime Adrian Taunay (who would later die during Langsdorff's expedition to Central Brazil - see Chapter V).

The corvette was equipped with all the necessary instruments for scientific research, a number of maps, books on natural history. astronomy, etc. She had 20 guns and a crew of 120 seamen.

The "Uranie" sailed from Toulon on 7 September 1817. arrived on 5 October at Gibraltar, and left on the 14 th. On the $22 n d$ she landed at Sainte-Croix, in Teneriffe, remaining in quarantine. due to diseases in the port. until the 28 th. She crossed the equator on 20 November 1817, and reached Rio de Janeiro (SF-23. 


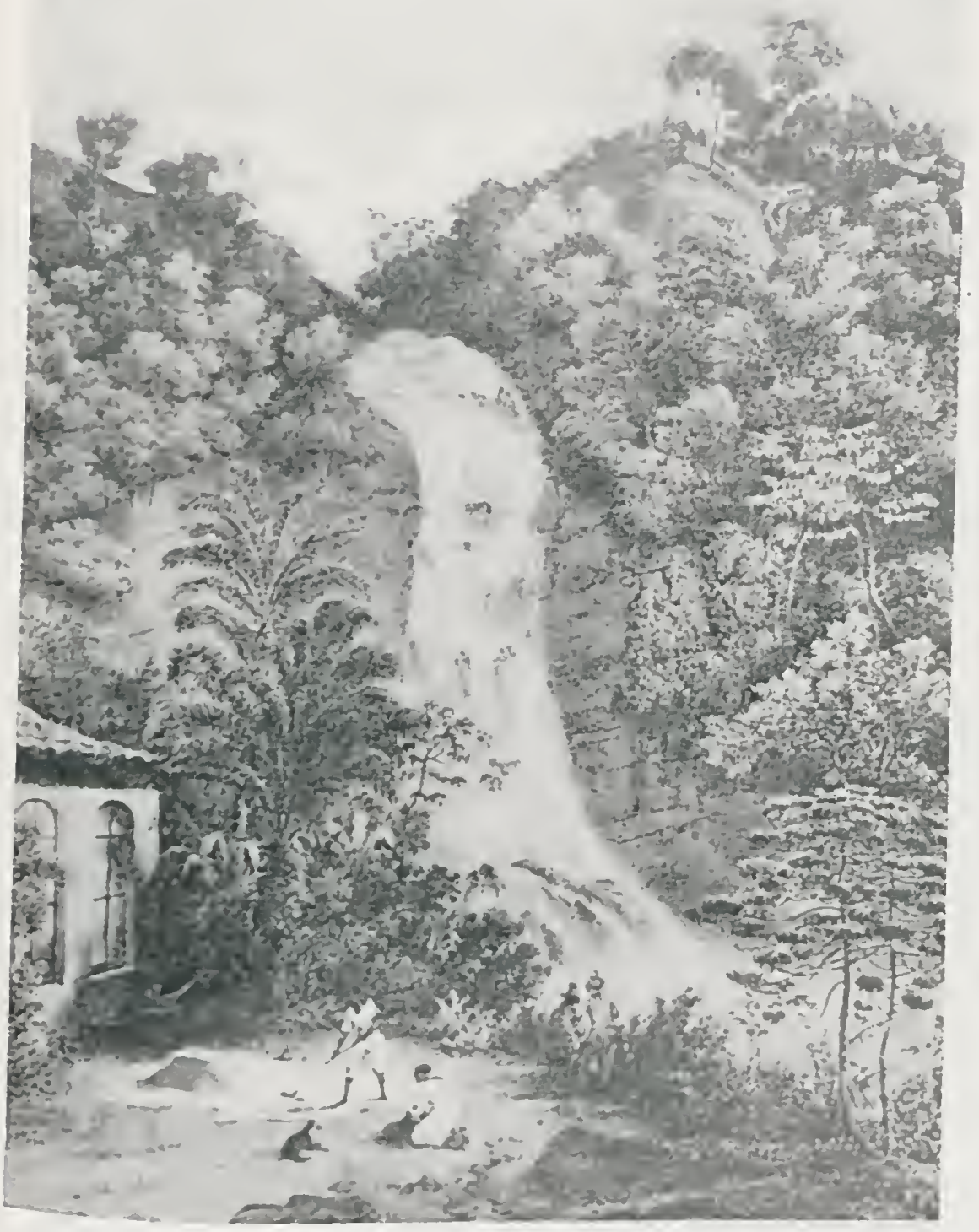

Tijuca uaterłall, near Rio de Janeiro (Rugendas) 


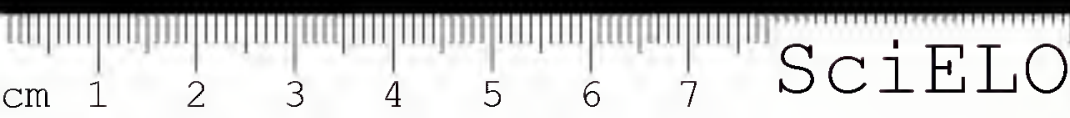


43-23a) on 6 December. There the crew remained for two months, while Gaudichaud-Beaupré, Quoy and Gaimard collected animals in the neighborhood of the city. Freycinet decided then to proceed with the voyage, and sailed for the Cape of Good Hope. Mauritius, and New Zealand.

After circumnavigating the globe, the corvette returned to South America, by way of Cape Horn, where several hydrographical observations were made. 'L'Uranie' touched at Tierra del Fuego on 25 December 1819. On 5 February 1820, the corvette was approaching Cape Desolación (SN-19, 55-72b), when the weather sudenly took a turn to the worse. The ship had to round Cape Horn to reach the protection of the Bay of Buen Suceso (in Argentina, SN-19, 55-65a), in the Strait of Lemaire. While at anchor there, a hurricane caused the ship to drift, and the cable had to be cut - the corvette was rapidly forced by the wind in the direction of the Falklands. entering "French Bay" (Baie Française) on $1+$ February. However, 'L'Uranie' hit a submerged rock and shipwrecked. The only solution now was to lower the life boats. No lives were lost, and the greatest part of the scientific results and collections were saved. The expedition itself, however, was over. While the crew remained in the Falklands, Captain Durville, the second in command, was sent in one of the boats to the Rio de La Plata for help. The waves carried the remains of 'L'Uranie' to the bottom of "Pernetty Bay" on 15 February.

Durville was able to obtain the help of an American ship. which went to the Falklands and brought the crew and the collection to Montevideo, where they arrived on 7 April. The American ship was acquired by Freycinet, being rebaptized as 'La Physicienne. After one month spent in Buenos Aires, Freycinet sailed for Rio de Janeiro, staying there until 13 September 1820. when the expedition returned to France, entering the port of Le Havre on 13 November 1820 . The voyage had lasted for 3 years and 2 months, covering about 26.000 marine leagues (of $4 \mathrm{~km}$ each).

Notwithstanding the accidents occurred during the expedition, the 'Jardin du Roi' received very rich collections. In the shipwreck of 'L'Uranie', is boxes had been lost, containing natural history collections. Those saved contained, according to Valenciennes, "aide-naturaliste du Muséum", 25 species of mammals, 313 of birds. 45 of reptiles, 164 of fishes, and a number of molluscs, worms, marine animals, etc. Of skeletons, 30 specimens were prepared. The collection gathered by Quoy, Gaimard, and Guadichaud-Beaupré comprised 4 new species of mammals, 45 of 
birds (and 3 new genera), 30 of reptiles, and 120 of fishes. preserved in alcohol.

With regard to the insect collection. Freycinet had sent to the Paris Museum, during the stay of the ship in Mauritius, 4 large boxes with approximately 200 Lepidoptera and 400-500 other insects, collected in Rio de Janeiro and neighborhood ("Brésil. Gaudichaud" of Macquart). These collections, therefore. were not in the shipwreck in the Falklands. On the return of 'La Physicienne'. Freycinet added 1,300 insects more to the Museum of Paris. Latreille estimated that around 300 species in all were represented in the collection.

The artists of the expedition. Arago and Taunay. and also Gaudichaud-Beaupré, had represented several natural history objects in their natural colours, especially the birds. fishes, molluscs. insects, and marine invertebrates. The drawings were also deposited in the Paris Museum (Barral. 1857: 135-175; Freycinet. 1828).

Gaudichaud-Beaupré stayed in Paris until 1831, when he left on a second voyage, this time aboard the frigate "L'Herminie". The voyage lasted for two years, and the expedition dropped anchor in Rio de Janeiro and several ports in Chile and Peru. Urban (1908) says that during this trip Gaudichaud-Beaupré also collected in São Paulo. Bahia. Mato Grosso, and Santa Catarina. It is very probable that "L'Herminie" touched Salvador (Bahia). Santos (São Paulo), and Florianópolis (Santa Catarina). but it is very doubtful that Gaudichaud-Beaupré ever collected in the province of Mato Grosso. During the stay in Rio de Janeiro Gaudichaud-Beaupré took to France the duplicates of the plants collected by Sellow. which had been turned over to the National Museum.

Returning from this royage. Gaudichaud-Beaupré embarked once more, and made his third trip. from 1836 to 1837, aboard "La Bonite".

The purpose of the voyage of the 800 -ton ship "La Bonite" was to transport to their various destinations consular agents appointed by the King of France, and at the same time to perform scientific observations.

The crew, commanded by Captain La Salle. consisted of 150 men. not counting the officers and passengers. The scientific commission was composed of Gaudichaud-Beaupré. zoologist and botanist: Eydoux, surgeon first class, zoologist: Chevalier, geologist: Touchard, in charge of the study of marine organisms: Darondeau, hydrographer: Lauvergne, artist: Touchard and Fisquet. aided by Missiessy and Dumatroy, in charge of the determination 
of geographical coordinates, as well as of other physical experiments.

"La Bonite" sailed from Toulon on 6 February 1836, proceeding directly to Rio de Janeiro (SF-23, 43-23a), and after a short stay there, to Montevideo (SI-21, 35-56a). Weighing anchor from Montevideo on 23 April 1836, "La Bonite" passed the following day by the Bahia de Todos Los Santos (in Argentina, SI-21, 35-57c), and on 5 May 60 leagues off Puerto Deseado (SL-19. 47-68c; SM-19, 48-68b). On 7 May, the ship passed by the Falklands. After passing Cape Horn. the ship reached the latitude of the Island of Chiloe (SK-18, 42-74d: SK-19, 42-72) on 3 June, anchoring in Valparaiso (SI-19,33-72d) on the 10th. Gaudichaud-Beaupré landed to visit a friend who lived there. The following day everything was ready for the scientific observations. The observatory was installed in the courtyard of a house. Darondeau and other officers took care of the experiments on physics and magnetism: Chevalier studied the geology of the country: meanwhile. Gaudichaud-Beaupré and Eydoux studied the animals and plants.

On 24 June, "La Bonite" sailed for Peru. Sailing along the coast, at a distance of 30-35 leagues, "La Bonite" arrived at Callao (SD-18, 12-77c), and proceeded to Cobija, then a Bolivian port, where the consul. M. Huet, had to land. The naturalists collected in Cobija until the 4 th of July, when "La Bonite" departed for the Sandwich Islands, Hawaii, Manila, the Philippines, Macao, Calcutta, and Pondichery (Barral, 1857: 231-233; Etcheverry Campaña, 1960; La Salle, 1845-1853).

Upon his return to France, Gaudichaud-Beaupré was made a member of the "Institut de France" and was attached to the Paris Museum, where he spent the rest of his life classifying and studying the plants collected during the three great voyages. He published several memoirs on the flora of the Falklands, and on the plants collected during the cruises of "L'Uranie" and "La Physicienne". He died in Paris in 1854 (Enc.; Urban, 1908).

\section{A. Plée}

Auguste PlÉE (born in 1787; died in 1825 in Martinique). was a French botanist. He started his career in several administrative jobs, and arrived to "chef de la division à la sécrétairie des conseils du roi". when he resigned, and sailed, as collecting naturalist of the Government, to the Lesser Antilles. He collected in Guadeloupe (starting on March 1820). Martinique (1820). St. Lucia (1821). St. Barthélemy (March 1821), and Martinique 
(1821); the years 1822 and 1823 were spent in Puerto Rico and Vieques; in August 1823 he visited St. Eustace and St. Christopher. In his manuscripts, preserved in the Muséum National d'Histoire Naturelle, Paris (MS 71, 72, 73). several localities of the Caribbean coast of South America are also cited: Isla Margarida, Cumaná, Gulfo de Cariaco, La Guaira, Macuto, Caracas and Cabo Blanco. He seems to have also visited the United States and Canada (vol. 3 of the "Atlas". MS 73). In the third volume of manuscript 73 are also mentioned the islands of Montserrat, St. Thomas and Saba. There are several unpublished plates depicting scenes of the Lesser Antilles islands in Plée's Atlas.

His collections have arrived to Paris in 1826, one year after his death in Fort-Royal. Martinique, the day where he was going to return to France. According to the entry in the Paris Museum book of accessions (Catalogue das animaux sans vertébres). "[Cet envoi de M. Plée, voyageur du Musẻum] consistant en insectes de differens ordres. N'a pas été catalogué. Les objets étaient en assez mauvais état. On a compté 14 boites d'insectes dont Sept de Lepidoptères. Chaque boite renfermait environ 50 individus."

Plée's collections were to be extremely useful to Macquart, since he collected in practically the same localities as Smidt, and other collectors, some years before. (Enc.: Pennel, 1945 : 42).

\section{The voyage of «La Coquille»}

The command of the expedition of "La Coquille" was granted by King Louis XVIII to Captain Louis Isidore Duperrey, who had a wide experience in sea cruises, having participated in other expeditions, such as that of the "L'Uranie", in the capacity of hydrographer. Born in Paris in 1786, he had joined the navy in 1803. and was also a member of the Academy of Sciences of Paris.

The complete plan for the expedition was submitted to the Marquis of Clemont-Tonerre by the commanders Duperrey and Dumont d'Urville. The Academy of Sciences and the Museum gave a decisive collaboration. Cuvier. Humboldt. Desfontaines and Latreille planned the general aspects and the specific purposes to which the naturalists should pay closer attention.

The scientific work was distributed between Dumont d'Urville, second in command in the expedition, and P. Lesson, botanist, who would also collect insects. Garnot, medical doctor, and chief surgeon of the ship. would be in charge of the collection of 
mammals and birds. Lesson would also collect geological samples, and Duperrey would study hydrography and the cartography of the regions visited.

"La Coquille" left Toulon on 11 August 1822, and anchored in Santa Cruz, Teneriffe, on the 22nd. Weighing anchor on the lst of September, the ship crossed the Tropic of Cancer on the 5 th, and a month later, went by the Islands of Martim Vaz $\left(\mathrm{SF}-24,29^{\circ}-20^{\circ} 30^{\prime}\right)$ and Trindade (SF-24, 29:20'-20'30').

On 16 October, they reached the Island of Florianópolis (SG-22, 48-28a) in Santa Catarina. Several excursions were made by the naturalists in the neighborhood of Florianópolis and on the mainland.

On 30 October, the ship sailed again and arrived in the Rio de la Flata ( 3 November). On the 17 th she passed Soledad, the easternmost of the Falklands, and on the 18th anchored in "French Bay". where Lesson collected with d'Urville. On 18 December 1822, they resumed the voyage, crossing Cape Horn on the first day of the New Year. On 20 January, the ship anchored in the bay of Concepción (SJ-18, 37-73d) in front of Talcahuano (SJ18, 37-73a). Their arrival coincided with the forced abdication of O'Higgins, and only on the 28th Lesson was able to make an excursion to the old part of the city of Concepcion, returning then to Talcahuano.

After the departure from Concepcion, "La Coquille" sailed along the coasts of Peru, arriving at Callao on 26 February 1823. There the naturalists remained for 6 days, making an excursion to Lima. "La Coquille" left Callao (SD-18, 12-77c) on 4 March 1823, touching Paita (SB-17, 5-81 c) on the 9th, remaining there until 22 March, and finally sailing for Tahiti.

The expedition brought to the Paris Museum only 12 specimens of mammals, 254 species of birds, some represented from 4 to 8 specimens ( 46 being new to science), 63 species of reptiles (15 or 20 of which were new). Lesson and Garnot collected 288 species of fishes, preserved in alcohol, almost all species represented by good series, and more than 80 representing new entities. Lesson had drawn more than 70 species of fishes in full colour. He also drew plates of molluscs, crustaceans, and other marine invertebrates. Molluscs were represented by 120 species ( 50 being gastropods).

More than 1,200 specimens of insects were collected by d'Urville. Lesson had also formed a collection of insects, from which d'Urville selected those that had evaded his investigations. The collection was organized by Latreille, in the Paris Museum, and according to him 1,100 species were represented, among 
which were 450 not previously represented in the Museum's collection, and 300 undescribed. The greatest number of species came from Lima and Payta, in Peru, and from Chile.

To finish with this expedition, it must still be said that 60 species of crustaceans were also prepared by Garnot, some of them representing new species (Araca Diaz, 1960; Barral. 1857: 176-222; Lesson. 1838).

\section{Leschenault and Doumerc}

In 1823 the Ministry of the Nary sent a mission to the French territories in South America, especially to French Guiana. Guadeloupe, Martinique, and Jamaica, to survey the agricultural progress of those colonies.

The man appointed to French Guiana was Louis ThÉODORE LeschenaulT DE LA Tour. Leschenault was born in Chālons-sur-Saone, France, on 13 November 1773. After the death of his parents he moved to Paris, where he studied natural history. Commissioned by the "Institut de France", he participated in Captain N. Baudin's expedition to Australia in 1800. aboard the ship "La Geógraphe", visiting Timor, where he felt ill in 1803; after exploring Java he returned to France, by way of Philadelphia, in 1807. In 1816, with the title of investigator of natural history. he travelled to the East Indies, visiting the Indian peninsula and Ceylon, and returning to France in 1822 (Urban, 1908).

For his third voyage, this time to South America, Leschenault invited his friend Adolphe Doumerc (born in Hamburg. 17 May 1802; died in Paris, 25 September 1868).

With instructions furnished by scientists of the Paris Museum, especially Cuvier, who followed the expedition with great interest. Leschenault and Doumerc left Paris on 25 May 1823. sailing aboard the corvette "Le Rhône" from Brest on 11 June. The corvette sailed directly to Rio de Janeiro (SF-23, 43-23a), arriving on $29 \mathrm{July}$. Doumerc and Leschenault collected plants. birds and insects in the city, and sailed on the 29th of August to Salvador (SD-24, 39-13c). Bahia, where they arrived only on 28 September, after a long and difficult voyage. The naturalists remained in that city for eight day. leaving on 5 November. for Cayenne. where they were to try to introduce the planting of tea.

After a short residence in Cayenne (NB-22, 5-52c). Leschenault and Doumerc proceeded to the colony of "Nouvelle Angoulème" (localization unknown) near the shores of the Mana River (NB-22, 6-5td) ("Lamana, Leschenault" of Macquart), whence they sent several collections to the Paris Museum. including the 
skeleton of a large ant-eater to Baron Cuvier. Doumerc visited the tribes of the Galibi and Arrowali Indians.

In December 1823, Leschenault departed for Surinam ("Guyane, Leschenault" of Macquart), without taking Doumerc along, due to lack of money. There he stayed for three months.

At the beginning of April 1824. Leschenault and Doumerc shipped to the Paris Museum the collections they had obtained, which filled 13 boxes. During the following months Doumerc stayed with Leschenault in Cayenne, without interrupting his studies and researches. He made several excursions to the nearby country, especially along the Oyapock (NA-22, 3-52a; NB-22, 4-52d) ("régions couvertes de forêt à l'Oyapock", of Macquart). The specimens gathered during those trips were then sent to France, and arrived there at the same time as the two naturalists.

Leschenault and Doumerc intended to leave in November for the Antilles, but Leschenault's health was very frail, and they had to depart from Cayenne on 31 August 1824 aboard the ship "La Bayonnaise". Caught by a strong storm in the night of 9 to 10 October, the ship remained in danger for several days. However, on 15 November the naturalists landed safely in Lorient (Girard, 1868).

The voyage of «La Thétis» and "L'Espérance»

On 2 March 1824, the frigate "La Thétis", commanded by Baron Bougainville, Jr., and the corvette "L'Espérance", commanded by Nouguer du Camper, sailed from Brest. They went first to India and China, and, after crossing the Pacific Ocean, approached the western coast of South America. On 15 December 1825. they landed in Valparaiso (SI-19, 33-72d). The crew went on an excursion to Santiago (S1-19, 33-71d), overland, proceeding afterwards to Curacavi (SI-19, 33-71c). Cuesta de Prado (SI-19. 33-71d). Rio de Purapel (SI-18, 36-72a), and then back to Santiago. On the 1Sth they rode to Salto del Agua, and on the 19 th to a farm of a certain Father Herrera, and to the Cerrito de Santa Lucia. On 8 January 1826 they left Chile, and after passing by the 1sla de los Estados (SN-19. 55-64a), touched the Island "Beauchene" (?) south of the Falklands. They then headed for Rio de Janeiro (SF-23, 43-23a), arriving on 2 March 1826. Bougainville Jr. made several excursions to the Botanical Gardens, Lagoa Rodrigo de Ereitas, Botafogo, Corcovado. Tiju$\mathrm{ca}$, etc. He also said that "Rio de Janeiro possesses a museum. which 1 visited several times $(\ldots)$. This was not at first wi- 
thout some difficulties which the director Monsieur Sylveira (italics mine) placed in the way when we wished to examine material in detail." (Translation by G. C. Steyskal).

Bougainville Jr. stayed in Rio waiting for Count Edmond de la Touanne, lieutenant of the Thétis, who had come from Valparaiso to Buenos Aires overland, with Bougainville's permission. His itinerary was the following:

19 January 1826. Valparaiso (SI-19, 33-72d) to Santiago (SI$-19,33-71 d)$.

26 January 1826. Chacabuco (SI-19, 33-71d) to Santa Rosa de los Andes (Santa Rosa, SI-19, 34-71a).

27 January. Entered Argentina (Provincia de Mendoza).

28 January. Cordillera del Portillo (SI-19. 34-70b).

29 January. Uspallata (SI-19, 33-69a).

1 February. Mendoza (SI-19, 33-69b).

5 February. Las Catitas (SI-19, 33-68c), La Dormida (SI-19, 33-68d).

7 February. San Luis (SI-19, 33-66c).

8 February. San José (SI-20, 33-66d), Rio Quinto (SI-20 $34-65 d)$.

9 February. Entered the Province of Cordoba. Achiras (SI-20 33-65d). Arroyo de la Baranquita (SI-20, 33-65d). Tambo (SI-20, 33-65b). Rio de las Barrancas (SI-20, 33-65b).

10 February. Tegua (SI-20, 33-64a). Santa Barbara (SI-20. 33-64a). Punta del Agua (SI-20, 33-65b). Arroyo San José (SI-20, 33-63a).

11 February. R. Saladillo (SI-20, 33-63d).

12 February. Entered the Province of Santafé, through Cruz Alta (SI-20, 23-62d), and then the Province of Buenos Aires. through Arequito (SI-20,33-61c). Arroyo del Medio (SI-21. 34-60d). Arrecife (SI-20, 35-60c).

14 February. Luján (SI-21, 35-59a). Buenos Aires (SI-21. 35-58a).

On 27 February 1826. Touanne left the Argentinian capital for Montevideo (SI-21, 35-56a), at that time theater of a war between Brazil and Argentina, and sailed to Rio de Janeiro to meet Bougainville.

Sailing from Rio on $\delta$ April, the ships arrived at Brest in 24 June 1826. All the collections made during the trip were deposited in the "Jardin des Plantes" (Bougainville. 1837). 


\section{Lacordaire and Banon}

Concerning these two naturalists we have very little information. JEAN THÉODORE LACORDAIRE was born in 1801 at Recey-sur-Ource, a small town in the department of Côte d'Or, situated in a hilly country near the sources of the Seine the Marne, and some of the tributaries of the Rhine. His father was a surgeon, and he was the eldest of four brothers, one of whom became the great Dominican preacher who acquired world-wide reputation by his eloquence and liberalism. Our Lacordaire was educated for the bar, but never became an advocate. Circumstances, of which we have no accunt, led him, at the age of 23 , to make a voyage to Buenos Aires, where he explored the Pampas for four months, and probably acquired or strengthened the tastes which he thenceforth evinced. After his return he prepared himself for a longer expedition; and for two years he traveled over La Plata. Uruguay, and the Brazilian Provinces of Rio de Janeiro and Minas Gerais. Not yet satisfied with his explorations of this part of South America, he visited it for a third time, and crossed the Continent, from Santiago in Chile to Montevideo. He returned to France in 1830, and published his first scientific essay. In the same year he went again to Cayenne, where he spent nearly 2 years, exploring all the inhabited parts of the colony, and following the Oyapock for more than one hundred leagues into the interior.

According to d'Orbigny (1853) on 20 October 1831 Lacordaire had arrived at the first rapids of the Oyapock (NA-22, 3-53a: NB-22, 4-52d), the following day he reached the "Saut Cachiri" (NA-22,4-52d). 50 feet high, and reached the place called Saint Paul (NA-22, 4-52d), which had been founded by the Jesuits more than a century before. On 24 October 1831. Lacordaire stayed at the house of an Indian chief, and after portaging many rapids and waterfalls, arrived on the 28 th at the mouth of the Camopi River (NA-22, 3-52a), where he remained among the Oyampi Indians. Proceeding upriver, he reached the Saut Aco, near the Yaroupi River (NA-22, 3-53d). Lacordaire stayed there for a while, at the house of a chief named Waninika, and then two weeks at the house of the chief Tapaiawar, studying the habits of the Oyampi Indians. Due to illness and fevers, Lacordaire had no strength to proceed, and returned from the Aco waterfall down the Oyapock to the coast, and then to Cayenne, after an absence of 80 days. 
On his return he published an account of the diurnal Lepidoptera and Coleoptera of Cayenne (1832, 1833a, 1833b). which. together with another paper on South American insects (1830). is all that he has given the world of his travels and adventures.

He appears to have devoted himself to the systematic study of the insects he had collected.

In 1835 he was made professor of zoology at the University of Liège, a position which he occupied for 35 years. He was married in 1834, and had 4 children, two sons and two daughters. He died on 18 July 1870, at the age of 69 , and was buried at Rosières, in the department of the Somme (Anon., 1870).

In one of Lacordaire's papers (1832), we find the following reference to BANoN: "the collection of Monsieur Banon is, to my knowledge, the finest that has been made in Cayenne. It is the fruit of 6 years of work, during which Monsieur Banon, besides his personal collecting, had at his disposal a certain number of negroes continually collecting for him. He bought indiscriminately all the insects that were brought to him; in this manner, sooner or later, everything that was taken in the colony came into his hands. It is thus that he has been able to gather in very large numbers certain rare species of which are taken only 3 or 4 specimens each year in the whole colony."

We shall now profit by the occasion presented by Banon to introduce into this part of the narrative a diggression on the activities of the negro collectors. Many of the specimens taken to European museums were the result of the efforts of these anonymous collectors, who many times explored the interior of the South American countries. A good report was given by Debret (1954: 17 -176, pl. 19), as follows, in translation: "lt is principally in the plantations that negroes destined to the profession of hunters are brought up. There, prepared since adolescence to accompany the troops, or simply their masters, in long and painstaking journeys, they always travel armed with a gun, not only for their personal safety. but also to obtain food during the indispensable halts in the midst of the virgin forests.

This kind of life becomes such a strong passion in the negro that he no longer aspires to liberty, unless it is to enter the forest as a professional hunter, and to travel without restraint under a compulsion that at the same time benefits his interests.

Free, no longer fearing the whip, the right of reasoning makes him a provider as clever as the white man. whose tastes he knows; and perfectly conscious of the value of a fine specimen mixed with the game brought to town, he sells it of preference 


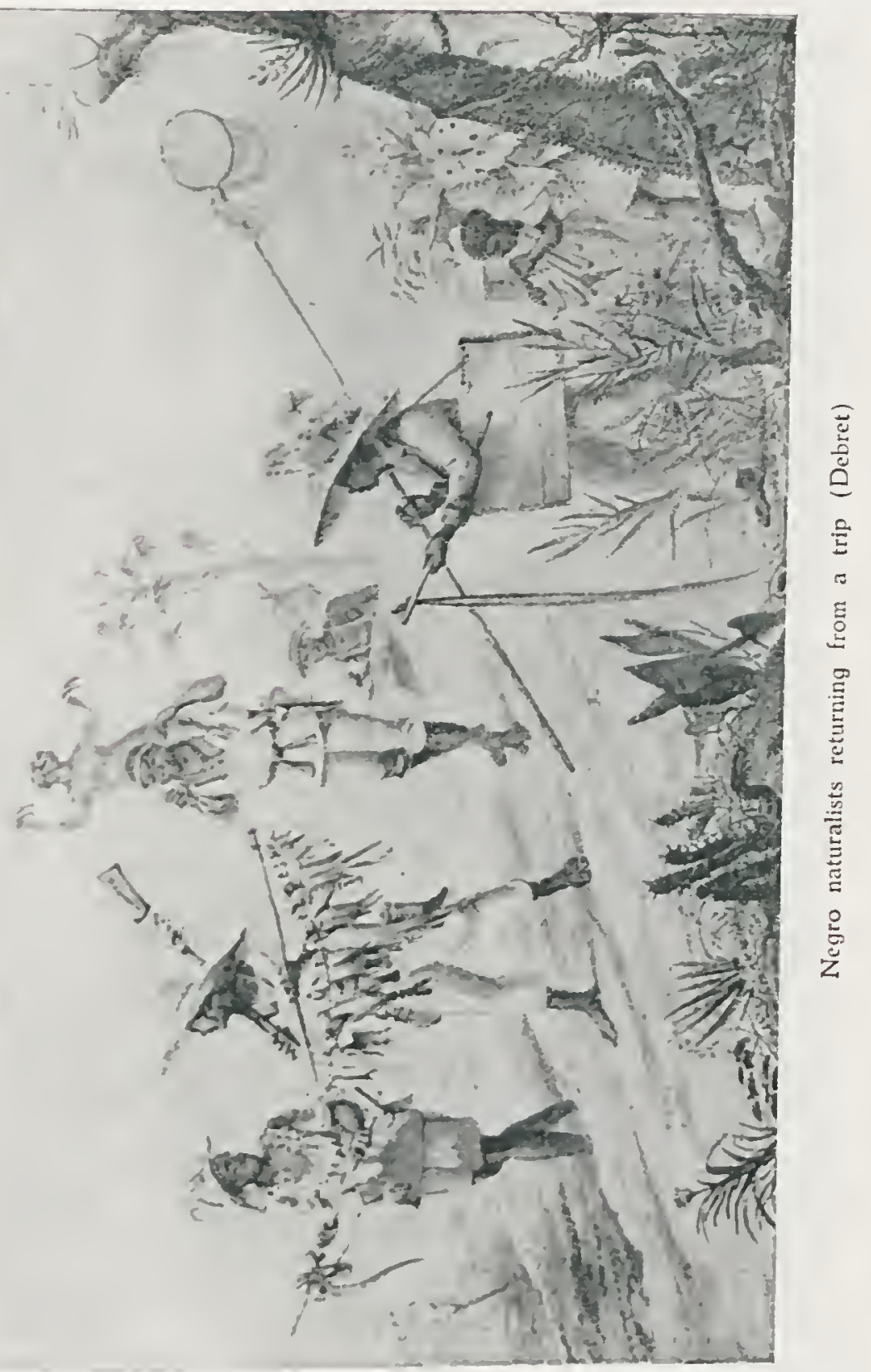

||||||||||||||||||||||||||||||||||||||||||||||||||||||||||||||||||||||||||||||

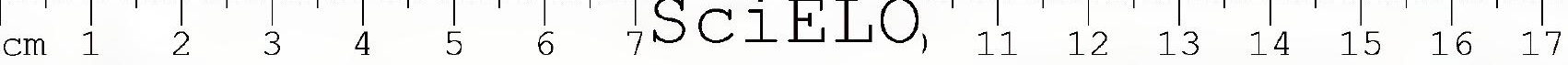




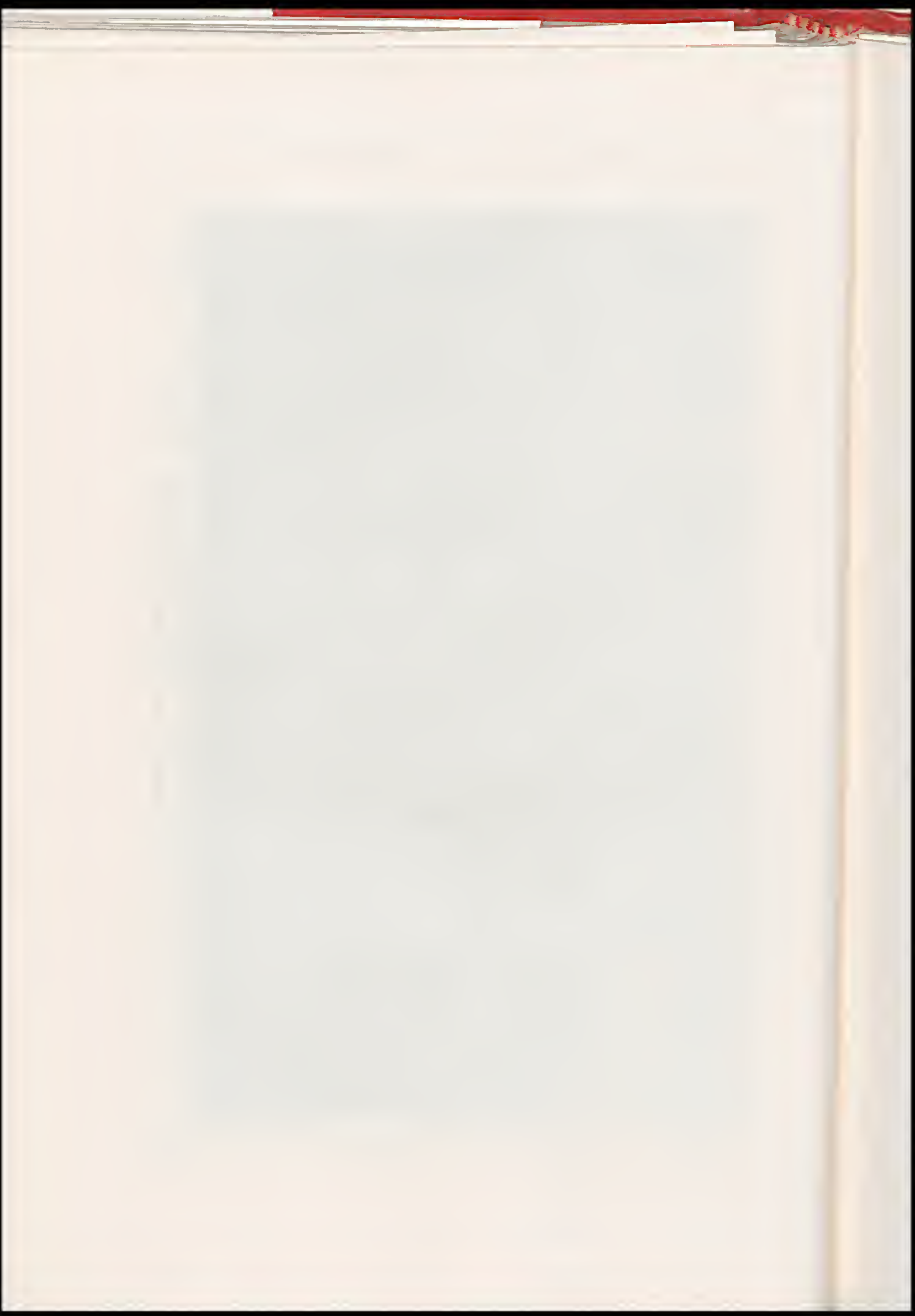


to the kitchen of a wealthy house, which will pay him well: combining intelligence with operosity he thus turns his profession into a very rewarding activity.

Other negro hunters, dedicated more especially to the collections of natural history, stay for many months in the forests, returning once or twice a year, bringing the collections obtained for amateurs of natural history, who wait for them in Rio de Janeiro.

For the same purpose, the administration of the Imperial Museum of Natural History (of Rio de Janeiro) employs several negro hunters scattered through several places in Brazil.

The negro, capable of being a good slave of a naturalist, can be considered as a model of the most generous traveling companion whose intelligence equals his faithfulness. That is the reason why we frequently see instances of generosity of foreign naturalists, who came to visit Brazil, and upon return from their wanderings, gave liberty to their faithful traveling companion, as a reward for the services rendered.

The slave, in these circumstances, acquires not only liberty but also a profession; as he has obtained through his liberator a certain facility in the preparation of natural history objects, he is demanded by other foreigners as guide. But this time, before the departure, he imposes the condition of being granted a certain amount of money, to be paid after the return, and then as a free man he starts a business trip.

Once in the city, in his turn, he hires some negro servants, as intermediaries, to offer to foreigners objects of natural history, whose sale brings him new orders. Notwithstanding, liberty is not always the desired reward; many negroes were seen, excessively deroted to their masters, whose lives they had often saved. demand as a reward only the permission to accompany them and to die in their service.

It is easy to recognize the negro naturalist, not only by his way of carrying a snake alive, but by the enormous straw hat studded with butterflies and insects mounted on long pins. He always proceeds armed with a gun and with an insect box hanging by his side $(\ldots)$.

One also know's in Rio de Janeiro, by the intensification of the activities of these negro naturalists, of the arrival of French ships, whose officers are generally great amateurs of collections of Natural History". 


\section{A. D. d'Orbigny}

Son of Charles Marie Dessalines d'Orbigny, Alcides DessaLINES D'ORBIGNY was born in 1802 in Coueron (Loire-Inférieure), and died in Pierrefitte (Seine) in 1857. He studied in the "Lycée de Rochelle", where he employed every holiday in the collection of marine animals. When 20 years old, he sent to the "Société d'Histoire Naturelle de Paris" a memoir on a genus of Gastropoda. In 1825 he published a paper on Foraminifera. which was printed the following year, bringing him a reputation as a naturalist.

Since 1824 he had selected Paris as his place of residence. and continued his studies of zoology and palacontology in the Museum. In 1826 the Museum decided to send him on an expedition to South America, giving him an anual stipend of 6000 francs. The Duke of Rivoli also helped to finance the expedition, with a grant of 3000 francs a year.

On 31 June 1826. d'Orbigny sailed from Brest, aboard "La Meuse", and, after short stops at the Canaries and Teneriffe, reached Rio de Janeiro (SF-23, 43-23a) on 24 September. By that time. Uruguay was trying to secede from the Brazilian Empire, and Argentina had also entered the ensuing revolutions. The situation caused some difficulties to d'Orbigny. who could not sail immediately to Buenos Aires, as he had intended. So he remained collecting in the neighborhood of Rio, visiting the Corcovado Mountain, São Cristóvão, and other places. Finally, he obtained a place on a ship bound for Montevideo, and left Rio on 11 October, arriving to the former city on the 29 th.

After exploring the vicinity of Montevideo (SI-21, 35-56a), he embarked on the "Zélée", which left him in Maldonado (SI$21.35-55 b)$, where he remained from the 17 th to the 30 th of November, when the "Zélée" returned to Montevideo. He established himself in the Capital until 10 January 1827. and then proceeded overland through Canelones (SI-21, 35-56b; 12 January). Rio Santa Lucia (SI-21, 35-56a). Rio San José (SI-21. 34-57d: 14 January). Arroyo del Rosario (SI-21. 34-57c: 17 January), and Las Vacas (SI-21, 34-58a; 20 January). From Las Vacas he took a boat, and, crossing the Rio de La Plata, arrived at Buenos Aires (SI-21, 35-58a).

In the Argentinian capital d'Orbigny met Lacordaire, and both undertook several collecting trips around the city. On 14 February 1827. d'Orbigny decided to go up the Rio Parana. He 
followed one of the arms of the Parana, touching at Baradero (SI-21, 34-59a; 17 February), Rosario (SI-20, 33-61d; 19 February), and La Bajada, the capital of Entre Rios (24 February). to Corrientes (SG-21, 27-59d), where he arrived on 15 March and stayed collecting.

On 22 April he rode to the interior of the Province of Corrientes, and through Guaicarás (?), Las Ensenadas (?). San Cosme (SG-21, 27-58c), La Cruz, reached Iribicuá (Iribú-cuá, 56-21, 27-58d; 25 April). There he suffered alternately from swarms of mosquitos and a biting cold. On the 3rd of May he undertook the return, by the same way, hunting along the route.

In Corrientes he stayed until 22 June. Then he rented a coach, and through San Roque (SH-21, 29-59b; 26 June) reached Rincón de la Luna (SG-21, 27-59b) on the 30th, in the south of the Province. As his companion had to draw a map of the region, d'Orbigny availed himself of this opportunity to travel with him in the neighborhood, until the 26 th of July. when they returned to Corrientes. There he stayed for another period, collecting not only in and around the city, but also on the islands of the Rio Parana.

On 20 September 1827 he decided to go on a more extended trip. going then to Itati (SG-21,27-58c) and on a second visit to Iribicuá, only seven leagues from the former locality. On 16 October he returned to Itati, with excellent collections, and on 7 November reentered Corrientes.

On his arrival in Corrientes he learned that the Indians of Misiones, in league with the inhabitants of the Province of Entre Rios, had attacked the village of Curuzú-Cutiá. Fearing the consequences of a civil war d'Orbigny decided to buy a boat to transport his collections and go up the Rio Paraná. On 12 December he left Corrientes and rode to Iribicuá. There a boat was built, and he went up the Paraná, arriving in Caacaty on 27 December. On the lst of January 1828, he went on to Taquaral (?), then to Yataity-Guazủ (?) on 4 January, a place 4 leagues distant from Taquaral and on the 13 th he was back at Caacaty. Two days afterwards he went to visit the Laguna de Iberá (SG-21, 28-57a; SH-21, 28-57c), returning to Caacaty on 22 January. He stayed in that village for one week; having decided that he had sufficiently explored the region, he left for Yataiti-Guazu again, with all his collections. and on 4 February returned overland to Corrientes. As he could not obtain transportation, he was forced to remain in that city from 9 to 29 February, using this time to put in order his travel notes. Finally, having obtained a small boat, 
which he sent to Iribicuá up the Paraná, d'Orbigny followed overland. On 1 March 1828 he returned to Corrientes. He visited next the mouth of the Rio Negro, where he made a good collection of insects. He also visited several Indian tribes, and undertook historical investigations. The swampy region was very rich in Culicidae. Tabanidae and other flies. D'Orbigny also cites Calliphoridae, whose larvae infested the wounds of the cattle of the area.

Once he had acquired a boat large enough for the transportation of his collections, d'Orbigny left Corrientes on 20 April 1828. sailing down the Paraná. He landed in Goya (SH-21. $29-59 \mathrm{c}$ ), remaining there for a short time, and proceeded down the river on the 27th; on 30 April he entered the Province of Entre Rios, and on 6 May the Province of Santa Fé, stopping in several localities to collect. On 12 May he entered the Province of Buenos Aires, reaching the capital on the 30 th.

In Buenos Aires he remained until 8 November, when he left to explore Patagonia: however, his ship had an accident near Punta de Lara. and the passengers had to return to Buenos Aires. D'Orbigny left again on 29 December. On 7 January 1829, he entered the Rio Negro (SK-20, 40-64d). between the Provinces of Buenos Aires and Rio Negro, and landed in Carmen de Patagones (SK-20, 41-63b). There he acquired a coach and horses, and on 13 January went to Bahia de San Blás (SK-20, 41-62a). 25 leagues from Carmen, arriving the following day. He explored every part of the Bahia, including several islands of the Rio $\mathrm{Ne}$ gro, and obtained valuable collections, including some specimens of seals, which he sent to the Paris Museum. He then returned to Carmen. where he remained, undertaking several excursions. until is February.

Next he visited a village of Patagones on the opposite bank of the Rio Negro. On 3 March he went down the Rio Negro to its mouth, remaining there in a "estancia" where he collected a great number of birds and insects. Returning to Carmen, he left again on 19 March. following the bank of the Rio Negro on horseback, in order to visit the "salinas" of Andrés Paz. There he gathered what he considered the best collections of his stay in Patagonia. Returning to Carmen, he took four days to organize his collections. He paid a second and short visit to the "salinas" on 25 March.

On 1 April 1829. he rode to Ensenada de Ros (?). where he remained from 3 to 11 April, and then sent a message to Carmen. to obtain a canoe for the transportation of the collections. 
When the canoe arrived, he sent the collections by way of the river, and returned to Carmen overland. Following that, he visited a sacred area of the Indians and went for a third time to Andrés $\mathrm{Paz}$ (22 April), returning to his headquarters at Carmen on the 24th. On the 29th he undertook one more trip, this time to San Javier (SK-20, 41-63a), where he remained for twelve days. On his return to Carmen (10 May) he dedicated himself to hunting nandus, but then the city suffered an attack of Indians. which ended only in the first week of July. During this brief period of peace, he visited Ensenada de Ros for a second time, and then left for Buenos Aires to seek help against the Indians. On his return, the city was agitated by internal revolutions, and on 22 July the Indians attacked again, and were beaten only at great cost.

On 1 September 1829, d'Orbigny gathered all his collections obtained in Carmen and its vicinity ("Rio Negro, M. d'Orbigny" of Macquart ) and went down the Rio Negro, returning to Buenos Aires.

He left Buenos Aires for the last time on 10 December, going to Montevideo, where he wanted to take a ship to Chile. He landed in Montevideo on the 12th, and learned that Uruguay was then an independent country, the República Oriental del Uruguay. On 26 December he departed from the eastern coasts of America, which he had explored for four years, and went to Chile.

The ship rounded Cape Horn on 19 January 1830, and then landed in Valparaiso (SI-19, 33-72d). D'Orbigny had hope to find peace to proceed with his investigations, but there the political situation was also bad and agitations occurred. He remained there from 16 February to 8 April, exploring the neighborhood of Valparaiso, and visiting Santiago (SI-19, 33-71d).

On 9 April he embarked aboard the "Kronpriz von Preussen", and reached Cobija on 14 April. On the 20th he embarked for Arica (SE-19, 18-70c) where he landed on the 23rd. He went overland to the interior of Bolivia, through Palca (SE-19. 18-70a). Tacna (SE-19, 1S-70c), and reached La Paz (SE-19. 16-68c) on 17 July. On the same day he proceeded to Obrajes (SE-19, 17-6Sa). Palca (SE-19, 17-68b: 19 July): Yanacachi (SE-19, 16-6Sd; until the 26th). Chupe (SE-19.16-68d; 27 July to 1 August). Chirca (SE-19,16-68d), and Chulumani (SE-19. 16-68d: 2 August), the capital of the Province of Yungas, where he stayed for some time in order to organize his notes and collections, and to send his notes to La Paz. On 25 August he went on through Irupana (SE-19, 16-67c), or Villa de Lanza 
(where he remained for 4 days), Circuata (SE-19, 17-67a). Suri (SE-19, 17-69a; 7 September), Inquisivi (SE-19, 17-67a), Charapacce (10 September), in the Province of Sicasica, and then through Capiñata (SE-19, 17-67a), Cavari (SE-19, 17-67d), and Machaca (SE-19, 17-67d), in the Departamento de Cochabamba (18 September). Proceeding through Chincuri (SE-19, 17-67d). Morochata (SE-19, 17-66a), Quillacolle (SE-19, 17-66c), Cochabamba (SE-19. 17-66c; 23 September). Tarata (SE-20, 18-66b; 21 October). Cliza (SE-20, 18-66b). Mizque (SE-20, 18-65a; 23 October). Chilon (SE-20, 18-65d; already in the Departamento de Santa Cruz). Mataral (SE-20.18-64c). Pampa Grande (SE-20. 18-64c). Samaypata (Samaipata; SE-20. 18-64d; 9 November), he reached his destination. Santa Cruz de La Sierra (SE-20, 18-63a), on 11 November 1830. There he established headquarters. collecting in the surrounding areas until May 1831.

On 21 June 1831 he left Santa Cruz de La Sierra, to visit the several missions in the eastern part of the Departamento de Santa Cruz. Crossing the Rio Grande (or Guapay) and the Rio San Miguel (30 June), he arrived in San Javier (SE-20, 16-62c), in the Province of Chiquitos, on 2 July. In that mission he remained for 4 days, going on to Concepcion (SE-20, 16-62). San Miguel (SE-20, 17-61b; 15 July). Santa Ana (SE-20, 17-61b; 19 July). and San Ignacio (SE-20, 16-61d: 29 July). where he remained until 5 August, then returning to Santa Ana. In this mission he stayed until the lst of September, when he decided to visit the missions of the South, going to San Rafael (SE-20, 17-60a: 3 September). San Nicolás (?), and San José de Chiquitos (SE-20, 1S-6Ib; 8 September). In San José he remained 6 days, exploring the vicinity and organizing his notes. Leaving on the 1 tith. he arrived in the Serranias de Santiago on 20 September. and on the 27 th proceeded to Santo Corazon de Jesús (SE-21. 18-59b; 29 September). From Santo Corazon he departed on 10 October for San Juan (SE-21, 18-60b: 15 October), and after staying 4 days there, retraced his steps, returning to San Javier.

After a short stay d'Orbigny went on a new expedition, this time to explore the Province of Moxos. leaving San Javier on 19 December, to visit a village of the Guarayo Indians. where he stayed until 25 January 1832. Then he went down the Rio San Miguel (SD-20, 16-54c, 15-64d), and reached the mission of Carmen de Moxos (SD-20, 14-64d), on the banks of the Rio Blanco, on 4 February. After less than a week's stay, he navigated the Rio Blanco to the mission of La Purisima Concepcion de Baures (Baures: SD-20. 14-64b), where he stayed until the 


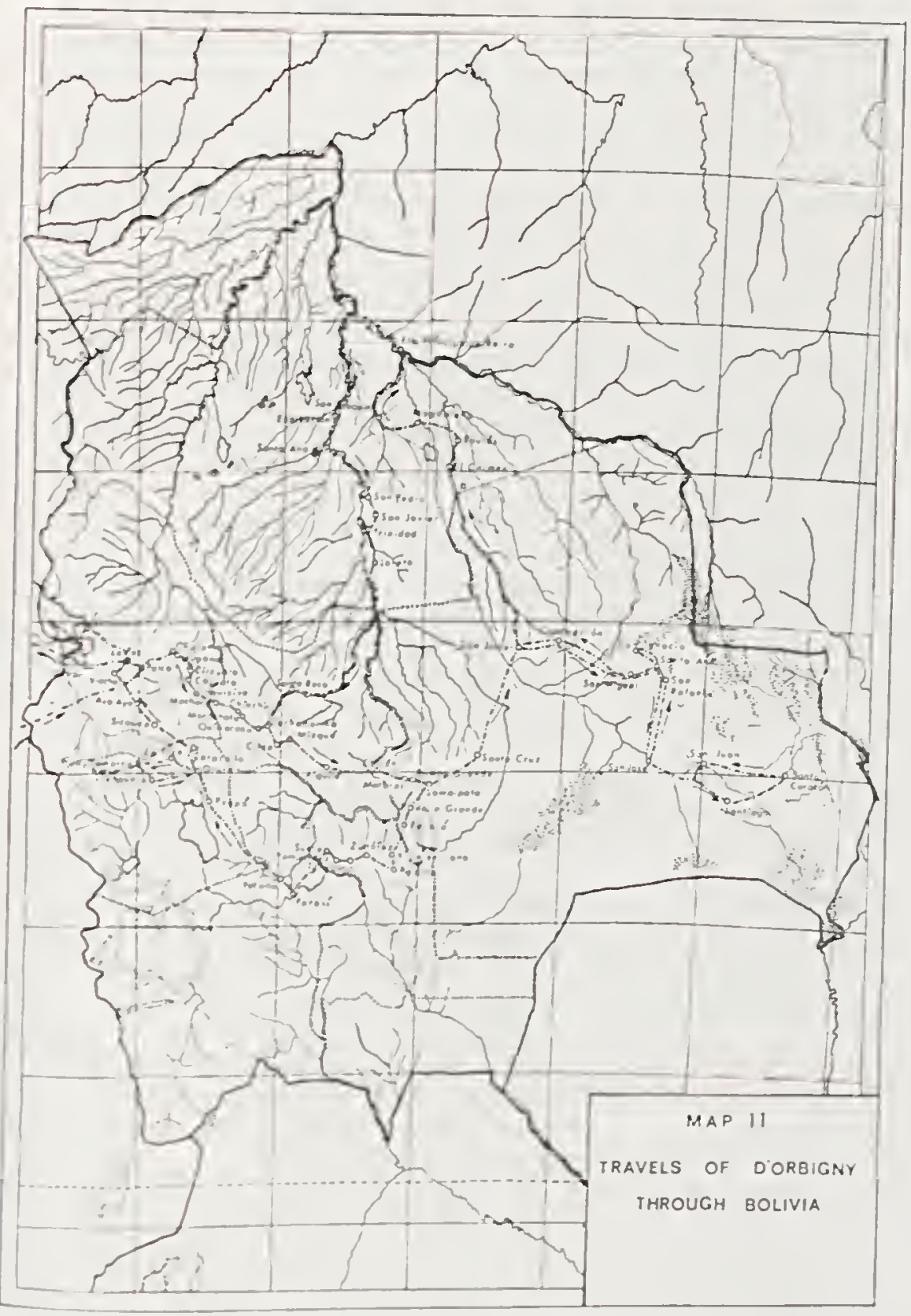

| ||||||||||||||||||||||||||||||||||||||||||||||||||||||||||||||||||||||||| C)

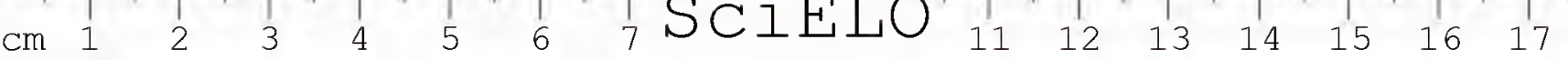


Ist of March. Proceeding then through San Ramón (SD-20, 13-65d), near the Fio Machupo (10 March), and San Joaquin (SD-20, 13-65d, 16 March); he followed the Rio Machupo to its mouth on the Rio Itenés or Guaporé, arriving at Forte Principe da Beira (SD-20,64-12c), in Brazil, and there remaining for four days. He left that village on 24 March, went down the Guaporé, entered the Mamoré. and on the lst of April reached the mission of Exaltación de La Cruz (Exaltación, 13-65c).

Proceeding up the Mamoré, on 7 April d'Orbigny arrived in Santa Ana de Moxos (Santa Ana, SD-20, 14-66b), and on the 14th at the mission of San Pedro (SD-20, 14-65d): the following day he departed for San Javier (SD-20, 15-65b) and on the 22nd reached Trinidad (SD-20, 15-65b). In the latter village he spent some time. leaving on 10 May; he passed the mouth of the Rio Ivari, arriving in Loreto (SD-20, 15-65d) on 12 May. On the 15th, availing himself of a convoy of canoes, he continued following the Mamore upstream, arriving on the 19th at the mouth of the Rio Chapare (SD-20, 16-57b, 16-65d). The convoy entered the Chaparc, whose navigation was very difficult because of fevers and heavy rains, and on the 27th reached the confluence of the rivers San Matco and Coni, which form the Chapare. By the Rio Coni d'Orbigny reached a village of the Yuracaré Indians on 28 May, and after 4 days went to the village of Asunción (?).

From Asunción he crossed the Cordillera Oriental on 8 June, and arrived in Cochabamba (SE-19, 17-66c), one month after his depart from Loreto. It was almost one year since he had last seen a large city, and d'Orbigny took great pleasure seeing the cupolas of the churches of Cochabamba. Everything seemed new to him, even bread, which he had last eaten in Santa Cruz de La Sierra. The French naturalist stayed in Cochabamba at the house of the ex-governor of Moxos. Don Matias Carrasco. with whom he discussed a new route from Cochabamba to Moxos. While in Cochabamba d'Orbigny received a safe-conduct from the President of the Bolivian Republic, which permitted him to investigate safely any part of the country.

After a stay of 24 days in Cochabamba, d'Orbigny left for another trip on 2 July, and crossing almost unknown regions reached the Rio Molato (SE-20.16-66d) on 30 July. On the lst of August he reached the Rio Securi (Sccurc, SD-20, 16-65a). which he followed to Moxos, where he arrired on 11 August. On 15 August he was in Trinidad (SD-20, 15-65b), leaving then for Loreto (SD-20,15-65d), where he had to wait several days 
for the arrival of pirogues. On the lst of September he went up the Mamore to the mouth of the Rio Sara (Rio Grande or Guapay), which he navigated to the mouth of the Rio Piray. (SD-20, 16-64c: 5 September). The Piray, in its turn, was followed with much difficulty, and d'Orbigny reached finally Santa Cruz de La Sierra (SE-20. 18-63a; 17 September). In Santa Cruz the naturalist worked very hard organizing his notes, and sent his collections to $\mathrm{La} \mathrm{Paz}$. While resting in Santa Cruz, nostalgia for his homeland became very strong. after so many years of arduous explorations, and he decided to leave the country.

On 17 November he left Santa Cruz de La Sierra for good, proceeding through Samaipata (SE-20, 18-6td: 23 November). Jesús del Valle Grande (Valle Grande; SE-20, 18-64c: 25 November), and Pucará (SE-20, 19-64a; until 2 December). crossing the Rio Grande (Rio Mizqué), and entering the Departamento de Chuquisaca. Then, through Villa Serrano (SE-20. 19-6łc). Padilla (SE-20, 19-6łc: 6 December), Zudáñez (SE-20. 19-65d). Tarabuco (SE-20, 19-65d: 10 December) and Yamparáez (SE-20, 19-65c), he reached the Capital of the Republic, Chuquisaca (Sucre; SE-20, 19-65c). In the Capital he made a long sojourn, leaving only on 10 March 1833. The following day he crossed the Rio Pilcomayo, entering the Departamento de Potosi, and arrived in Potosi (SE-20, 20-66b) on 15 March. Leaving on 28 March, he passed through Yocalla (SE-20, 20-66b). and entering the Departamento de Oruro, proceeded through Poopó (SE-19, 18-67c), and entered the city of Oruro (SE-19, 18-67a) on the 3rd of April.

From Oruro he decided to visit some more localities, and on 5 April departed for La Joya (SE-19, 18-68b). Huayllamarca (SE-19, 18-68b). Totora (SE-19, 18-68a). Carahuara de Carangas (SE-19, 18-6Sa), and Sajama (SE-19, 18-69d), returning to Totora (11 April) and Huayllamarca. In the latter village he leamed from a priest of a recent discovery of antiquities in the nearby village of Llanquera (SE-19, 18-68d), 10 leagues southeast of Huayllamarca. In spite of his desire to reach the coast as soon as possible, he could not lose this opportunity of increasing his archeological collections, and went on to Llanquera. To his disappointment, however, there were no antiquities, and he returned to Oruro (SE-19, 18-67a) on 13 April.

Two days afterwads, he went on through Caracollo (SE-19. 18-67a), entering the Departamento de $\mathrm{La} \mathrm{Paz}$, and passing Sicasica (SE-19, 17-68d; 17 April). Ayo Ayo (SE-19, 17-68c) and Viacha (SE-19, 17-6Sa), arrived at $\mathrm{La} \mathrm{Pa}=(\mathrm{SE}-19,16-6 \mathrm{Sc})$ on 
19 April. In La $\mathrm{Paz}$ his collections gathered during a period of three years, and sent from several localities in the interior of the country were waiting. The specimens were selected and packed. As d'Orbigny had no intention of leaving Bolivia without paying a visit to Lake Titicaca, on 4 June he made an excursion to that place, visiting Tiahuanaco (SE-19, 17-69b), famous for its archeological monuments, the Lake Chucuito (or Titicaca: SE-19, 16-69c), and Achacachi (SE-19. 16-69d; 9 June). where he caught malaria. The malady forced him to return to La $\mathrm{Paz}(\mathrm{SE}-19,16-68 \mathrm{c})$, where quinine sulphate cured him. Upon recovery, he still visited several other localities near $\mathrm{La}$ $\mathrm{Paz}$, and finally left on 27 June 1833. going to Tacna (SE-19, $18-70 \mathrm{c}$ ), in Peru, and then to the port of Arica (SE-19, 18-80c) in Chile.

Aboard the "Philanthrope" on 25 July, d'Orbigny travelled to the Peruvian port of Islay (SD-18, 17-72a), where the ship had to deliver some commercial goods, and there remained until the 7th of August. From Islay, the "Philanthrope" sailed for Callao (SD-18, 12-77c), where d'Orbigny remained for one week (7-14 August), visiting Lima (SD-18, 12-77c) in the meantime. On 3 September the ship finally left the Peruvian coast, and sailing at a distance of 100 leagues from the coast to avoid contrary winds, reached Valparaiso (SI-19,33-72d) in Chile on the 27th of September. On 18 October d'Orbigny left the last city which he would visit in South America, and after rounding Cape Horn, sailed to France, entering the mouth of the Gironde on 2 February 1834.

The collections brought home by d'Orbigny, gathered in South America from 1826 to 1833 , comprised 160 species of mammals, 860 of birds, 115 of reptiles, 166 of fishes, 980 of mollusks and other marine invertebrates, 5.000 of insects, and 3,000 of plants, in addition to geological, paleontological, and ethnographic materials.

In that same year of 1834 he received the "Grand Prix" of the Geographical Society of France, and his relation of travels, including 500 coloured plates, was printed at the expense of the French Government.

From 1840 on, d'Orbigny dedicated himself to the study of French paleontology, undertaking several trips, and gathering a collection of more than 100,000 fossils, which was acquired by the Paris Museum in 1858 for 50,000 francs. In 1853 he assumed the post of "professeur" of paleontology of the Paris Museum, and soon afterwards was placed in charge of the admi- 
nistration. He wrote numerous books on zoology and paleontology, and a "Dictionnaire Universel des Sciences Naturelles" in 55 volumes. He died on 30 June 1857 at Pierrefitte (Seine) (d'Orbigny, 1835-1847, 1945: Reyes Bianchi, 1960).

\section{«Vauthier»}

Nothing is known about the life of VAutmier. He arrived in Rio de Janeiro (SF-23, 43-23a) in December 1831, and stayed in the city from December 1831 to February 1832, exploring the Gávea, Santa Teresa, Laranjeiras, etc. He went to Pôrto Estrêla (12 February 1832), visiting Langsdorff's Farm Mandioca, near the Serra dos Órgãos, and then went to Minas Gerais, through Borda do Campo, Barbacena (SF-23, 44-21d). Congonhas do Campo (SF-23, 44-20d). Itabira (SE-23, 43-20a). Bela Fama, Sabará (SE-23, 44-20b). Serra da Lapa, Diamantina (SE-23, 44-18d; the ancient Tejuco), where he stayed for 2 months, Mariana (SF-23,43-20c), where he stayed for six weeks (until the beginning of October, 1832), and then returned to Rio de Janeiro, visiting the Corcovado, Ilha do Governador, and Serra dos Órgãos (for six weeks). Finally, he returned to France, arriving at the port of Toulon on 21 May 1833 (Urban, 1908).

\section{«Sylveira»}

The "Sylveira" to which Macquart refers so often in the first volume of his "Diptères Exotiques", is probably JoĀo DA Silveira Caldeird, director of the National Museum of Rio de Janeiro. He was called "Sylveira" by Bougainville Jr. (see above), who visited the Museum during his stay in Rio de Janeiro. in 1826.

Jox̃o da Silveira Caldejra was born in Rio de Janeiro on 28 June 1800 and died in the same city on 4 July 1854. He studied medicine at the University of Edinburgh. When 19 years old he was employed as first preparator in the "Jardin des Plantes" in Paris, where he worked with Vaucquelin, Haüy, and Laugier. staying there until his return to his home country.

Arriving in Rio de Janeiro, he was commissioned, together with the bishop of Anemuria and Manuel da Arruda Câmara, to revise and publish the "Flora Brasiliensis" of Father Jose Maria- 
no da Conceição Velloso. Silveira-Caldeira was professor of chemistry of the old military school, and in 1823 was made director of the National Museum of Rio de Janeiro.

Following the proclamation of Brazilian Independence by Dom Pedro I in 1822. José Bonifácio de Andrada e Silva was appointed Minister of the Empire. Being also a naturalist, José Bonifácio made an appeal to all naturalists who were visiting Brazil at the time to donate duplicates of natural history objects to the National Museum.

Baron von Langsdorff was the first to make a gift of specimens, including his collection of mammals and birds from Europe. Antônio Luis da Silva Manso, naturalist who accompanied Natterer to Mato Grosso, was also one of those who gave collections to the Museum. Natterer, Beske, and especially Sellow, who was employed by the Museum, as we have seen in Chapter V, increased the collections.

Silveira Caldeira also obtained from the Minister of the Empire, Estêvão Ribeiro de Rezende, afterwards Marquis of Valença, a directive to the presidents of the Brazilian provinces that objects of natural history should be sent to the National Museum. From the president of Pará. for instance, he received specimens collected by the "físico-mor" Antonio Correa de Lacerda. Lacerda was born in Portugal in 1777 and died in Brazil in 1852. He was a medical doctor and naturalist, and published several memoirs on natural history. Coming to Brazil in 1818, he became established in Belém, joining in the turbulent politics of the time. $\mathrm{He}_{\mathrm{e}}$ was one of the members of the Government of Para in 1823, and was forced to migrate to the United States during one of the revolutions in that province. He was a member of the "Instituto Histórico e Geográfico do Brasil", and of the now extinct "Sociedade Velosiana", to which he willed all his books, manuscripts, and scientific collections. His collections sent to the National Museum were possibly all from the neighborhood of Belèm.

Also from the Amazons the National Museum received collections gathered by the Italian naturalist FrANCESCO RICCARDO ZA.N. Zani was a native of Livorno, and had lived in the Province of Rio Negro (present State of Amazonas) for 14 years when Spix and Martius visited that province. Zani was a lieutenant-colonel of the Portuguese Army, and came to Brazil during the government of Dom Joào VI. Later on, he served the Brazilian Army, participating actively in the movements for the independence of the country, and became an active member in the political movements of the Amazonian provinces. During se- 
veral years he collected natural history specimens in the Amazons, and accompannied the naturalists Spix and Martius on most of their trip on that river.

Another naturalist who contributed with collections to the National Museum, was Rochus Scrüch, who came with the Archduchess Leopoldina, as we have seen. Schüch stayed only a brief time in the service of the Archduchess as librarian and curator of the cabinet of natural history. Later on. he dedicated himself to mining, establishing an iron works in Capanema. $\mathrm{Mi}$ nas Gerais, and was a teacher of sciences in Rio de Janeiro. He became an intimate friend of the Emperor Dom Pedro II, and died in 1844 .

Among the French naturalists who visited Rio and donated collections to the Museum, a certain PRÉGENT, who accompanied Saint-Hilaire in his voyages, after the departure of Delalande, must be cited. Prégent died in the Rio das Mortes, during Saint-Hilaire's second trip to Minas Gerais.

Silveira Caldeira also established during his directorship several exchanges with European Museums. It is known, for instance, that a collection of minerals was sent to Prince Christian of Denmark, and that collections contained in 17 boxes were sent in 1825, by order of Dom Pedro I, to the Berlin Museum. It is very probable that Silveira sent the collection of Diptera of the National Museum of Rio de Janeiro to the Muséum d'Historie Naturelle of Paris, although unfortunately we were not able to find in the archives of the Museu Nacional do Rio de Janeiro any documents related to this shipment. This negative evidence is not very strong, however, since many documents of the first Empire related to the Museu have been lost. Another possibility is that the collections were sent through one of the French naturalists who visited the Museum. It is known that Gaudichaud. -Beaupré took to France Sellow's collection of plants, which belonged to the Museu Nacional. He or some other naturalist may have also transported the insect collections.

So, it is very difficult now to know definitely whence came the Diptera described by Macquart in his "Diptères exotiques". attributed to "Sylveira". Most of the specimens came certainly from Rio de Janeiro. since the negro naturalists employed by the administration of the museum would find it easier to collect in the rich forests around the city, and most naturalists before that epoch had collected only in Rio or Minas Gerais.

At the end of 1527. Silveira Caldeira left the Museu Nacional do Rio de Janeiro, and was appointed director of the "Casa 
da Moeda". The remainder of his life is not known, but must have been very sad, for in 1854 he tried to commit suicide by taking hydrocyanic acid. As probably the substance was decomposed, it did not operate, and Silveira Caldeira cut open his throat with a knife (Blake, 1898: 51: Lacerda. 1905; Ladislau Netto, 1870).

The collections attributed to "Sylveira" must have been very rich, since that name is very frequently cited in Macquart's first volume of the "Diptères Exotiques", and several species have been named in his honor (sylveirii).

\section{The voyage of «La Favorite»}

Returning from his circumnavigation, after having visited India and China, Captain Cyrille Pierre Thêodore Laplace touched the Island of Masafuera (SI-18, 34-81b) (Juán Fernández Group), on 13 November 1831, and on the 16th. Cape Grumilla, in Valparaiso (SI-19, 33-72d), Chile, remaining there until 10 December, when he returned to Masafuera (18 December). Rounding Cape Horn, he landed in Tierra del Fuego, and next sailed directly to Rio de Janeiro (SF-23, 43-23a). staying in the Ilha dos Ratos (Bay of Guanabara). from 31 January to $8 \mathrm{Fe}$ bruary 1832. On the 9th of February he left Rio de Janeiro, and sailed for Toulon. France. Some insects were collected during the stops (Eicheverry Campaña, 1960; Laplace, 1833-1835).

\section{F. R. M. Lepricur}

Francols ReNé Mathias Leprieur was born in Saint-Dié, Vosges, France, on 17 April 1799. He was "pharmacien de première classe" in the French navy. He spent almost all his life in French Guiana. which he explored several times as entomologist. In July 1832. he left Cayenne (NB-22, 5-32c) to explore the interior, and followed the Oyapock River (NA-22, 3-52a; NB-22,4-52d) to its sources. Although no details are known of his trip, it is said that Crevaux (1883) did the same itinerary.

On his return to France, he shipwrecked on the coast of Bretagne, on 15 January 1833. losing almost his entire collection of insects, made during the voyage up the Oyapock, as well as the material collected in Cayenne (Anon., 1833: xv, 1xxviii). He died in 1870 (Saulcy, 1894: 453-458). 


\section{Claude Gay}

Claude Gay was born in Draguignan, capital of the Department of Var, France, on 18 March 1800. His first studies were made in his native town, and at the age of 18 he went to Paris to study medicine and pharmacy. He soon abandoned those studies to dedicate himself to the natural sciences. He attented lectures at the Paris Museum, given by Fèe, Cuvier, Desfontaines and Jussieu.

With G. B. Balbis he went collecting plants in the French Alps, and then in Italy (Carrara), in 1822. He returned to France in 1828, and was invited by Pierre Chapuis to go to Chile to teach physics and natural history in a school in Santiago. Gay accepted, and sailed with Chapuis and others, from Brest, at the end of May 1828. On their stop in Rio de Janeiro (SF-23. 43-23a). Gay collected plants (described by Jussieu and Cambassèdes in the "Flora Brasiliae Meridionalis"). and did some geological observations. He also collected during the two other stops of the ship, in Montevideo (SI-21, 35-65a) and Buenos Aires (SI-21,35-58a), and finally arrived to Valparaiso (SI-19,33-72d) on $S$ December 1828.

He began to teach in the "Colégio Santiago", using his spare time to collect in the neighborhoods. Through Jose Vicente Bustillos, "Boticario" in Santiago, who was a close friend of the Minister Portales, the Chilean Government commisioned Gay to explore the country. The decree was signed by President Ovalle on 14 September 1830.

Gay's first explorations were in San Fernando (SI-19. $35-$ 71 b; 20 March 1831), in the province of Colchagua. However, the lack of equipment forced him to go to France. Before leaving Chile he visited Juan Fernández (SI-18, 33-81d). His voyage to France was paid by the Chilean Government. On 14 March 1832 Gay sailed for Bordeaux in the French frigate Oedipe. Upon his arrival in France, he deposited his collection in the Paris Museum. In the beginning of 1833 he published in vol. 26 (pp. 369-393) of the Annales des Sciences Naturelles. his "Aperçus sur les recherches d'Histoire Naturelle Eaites dans l'Amérique du Sud, et principalement dans le Chili, pendant les années 1830 et $1831^{\circ}$. At the end of 1833, with the scientific literature and instruments he had obtained, he returned to Chile. He left Bordeaux on 1 February 1834, aboard the Sylphide, arriving to Valparaiso on 13 May.

At the end of October 1834, he explored the provinces of Valdivia and Chiloe, and passed thence to Coquimbo and San- 
tiago, entering the Cordilleras to study the San José Volcano. In the end of 1836 he moved to Santa Rosa de los Andes. In February 1838 he explored the provinces of Talca, Maule, Concepcion, and part of the territory of Arauca. The collections were organized in 1838, being placed in a special building given by the Government.

Commissioned by Minister Don Mariano Engaña to do some historical investigations related to Chile in the archives of the ancient vicekingdom of Peru, he went to Lima in March, 1839, and explored Tingo Maria (SC-18, 9-76d). Cuzco (SD-19, 14-71a), the valley of Santa Ana (?. SD-19,15-76b), the Rio Urubamba (SD-18, 12-73c). Arequipa (SE-19, 16-72d). Lima, and Callao (SD-18, 12-77c).

Returning to Chile, he continued his work, organizing the data for his work "Historica fisica y politica de Chile", taking part of his time to organize the Chilean Museum. He still collected in Valparaiso, Copiapó. Huasco, and Santiago. He was made Chilean citizen, and the Government furnished money to print his work. The Congress approved the presidential act on 29 December 1841.

He left Valparaiso in June 1842, and on the 24th of the same month embarked for Bordeaux. He arrived in Paris on October, and made contacts with specialists to prepare the various portions of his "Historia". The work was finally printed, in 28 volumes.

Gay returned to Chile in 1863 and died there on 29 November 1873 (Barros Araña, 1876; Porter, 1902).

\section{Erancis de Castelnau}

Francis Louis Nompar de Caumont de LAporte de CasTELNAu was born on 25 December 1810 , and died on 4 February 1880 in his residence of Aply-Place (East-Melbourne). Australia, as consul of France.

Very little is known of his life. Castelnau was one of the iounders of the French Entomological Society. At the end of 1837 he visited North America, travelling for 5 years through the States of the Union. Texas, and Canada. Having made the acquaintance of several authorities. Castelnau was invited by the Government of the Union to serve as American Consul in Lima. As he could not accept the position without permission of the French Government, he returned to Paris in 1841, where he published his "Vues et scènes de l'Amérique du Nord". King Louis 
Philippe, learning of this intention to serve the Government of the Union, decided to send him on an expedition to South America.

As companions on that trip Castelnau had Eugêne d'Osery, "ingénieur au corps des mines" who had attracted the attention of the scientific world during his examination in the "Ecole Polytechnique".

Hugh Algerson Weddel (born on 22 June 1819 in Birches-Houses, near Painswick. England, and died on 22 June 1877) was to be the botanist of the expedition. Weddel had studied botany with Adrien and Jussieu, and graduated in medicine in 1841. He had written a book on plants of the environs of Paris. and in 1843 joined Castelnau's expedition, accompanying him to Bolivia. From 1846 to 1851 , as we shall see, he travelled alone, and from Islay in Peru went to North America, before returning to Europe (Hoehne, 1942: 242).

Émile Douville, an employee of the Muséum National d'Histoire Naturelle was to help Castelnau with the zoological collections, as preparator.

Castelnau's plan was first to cross the South American continent from Rio de Janeiro to Lima, trying to follow, when possible, the dividing line between the hydrographic basins of the Amazons and of the Rio de La Plata; then to travel down the Amazons River. With those two transects, he hoped to establish the possibility of a communication between the two great basins, thus permitting uninterrupted navigation from the Antilles to Buenos Aires.

Aboard the French brig "Dupetit-Thouars", the members of the expedition sailed from Brest on 30 April 1843. arriving at Rio de Janeiro (SF-23, 43-23a) on 17 June. Through the French Consul. M. Taunay, they went to live in the former home of Baron von Langsdorff, at the side of the beautiful Gloria church (Igreja da Glória).

During their stay in the city. several points were explored. their excursions extending to Praia Grande (now the city of $\mathrm{Ni}$ teroii; SF-23, 43-23b). While Castelnau and d'Osery made astronomical observations. Douville collected animals around the city. Castelnau visited on several occasions the "Instituto Histórico e Geografico do Brasil". to study maps of the interior of the country, and documents relating to Brazilian history, especially the penetration of the "Bandeirantes" from Sảo Paulo. who in former centuries had entered the back country in search of gold and Indian slaves. At the end of 1843 Castelnau and d'Osery sent to the French Academy of Sciences their first observations made in Rio de Janeiro. The insect collection gathered in and 
about Rio was sold by Castelnau to the Musoum National d'Histoire Naturelle by 1.500 francs (cf. Catalogue des animaux sans vertèbres, vol. 3, pp. 102-104 [Paris Museum accessions book]).

Leaving the city on 12 October 1843, furnished with letters of recommendation to the authorities in the provinces, the commission entered the Rio Inhomirim, arriving at Pôrto Estrêla. Passing by Mandioca, they noted the state of abandonment of that Farm. after the death of Baron von Langsdorff. From 21 to 25 October they visited Magé (SF-23, 43-23a) and reached Sumidouro (SF-23, 43-22d). On 6 November they arrived at Encruzilhada (SF-23, $4322 \mathrm{c}$ ) and on the 8 th the banks of the Rio Paraibuna. the border between the provinces of Rio de Janeiro and Minas Gerais.

Proceeding by way of Juiz de Fora (SF-23, 43-22a; 10-11 November), Chapéu d'Uvas (SF-23,44-22b). crossing the Serra da Mantiqueira under strong rains, Barbacena (SF-23, 44-21d; 28 November). Queluz (Queluzitas, SF-23, 44-21b; 1 December). and Ouro Branco (SF-23, 44-21b; 2 December), they arrived to Ouro Prêto (SF-23, 44-20d) on 5 December 1843.

In the capital of Minas Gerais they met the Danish naturalist Claussen (see Chapter $V$ ), and with him they proceeded to Cachoeira (SF-23.44-20c; 11 December), staying at Claussen's home, where a real Museum could be seen. Claussen maintained several persons as curators of the different parts of his natural history collections, and offered to Castelnau several objects, including a herbarium of the regional flora. From Ouro Prêto Castelnau and his companions also visited the village of Mariana (SF-23, 43-20c).

Leaving Ouro Prêto (SF-23.44-20c) on 17 December 1843. they met Claussen again the next day in Cachoeira (SF-23, 44$-20 \mathrm{c})$. On the 19 th they reached Itabirito (SF-23, 44-20d). where some Englishmen had a gold mine. There they were received by a certain Mr. Champion, director of the establishment. Departing on the 22nd, they visited the mines of Morro Velho, at the time also operated by Englishmen; there the naturalists spent Christmas. On the 27th they reached Sabara (SE-23. $44-20 \mathrm{~b})$. leaving that city only on 8 January 1844 , proceeding to Curral del Rei (presently Belo Horizonte, capital of the State of Minas Gerais: SE-23, 44-20a).

Proceeding by way of Bicas (SE-23, 44-20b). Mateus Leme (SE-23. 44-20a; 15 January). Rancho do Mato (?: 16 January). Pitangui (SE-23. 45-20b; 20 January). they crossed the Rio São Francisco, and passed through Dores (Dores do Indaiä; SE-23. 46-19d; 26 January). Sāo Francisco de Chav'es, and Sảo 
Sebastiāo (5 February 1844). They reached Patrocinio (SF-23. 47-19a) on 8 February, and remained there for some days.

Leaving Patrocinio on 14 February 1844, they crossed the Rio Paranaiba on the 22 nd, entering the province of Goiás. Proceeding through Catalão (SE-23, 48-18d; 24 February), they remained until the 5th of March collecting in the vicinity, putting their notes in order, and organizing the collections.

Leaving Catalão ahead of his companions, since he had to meet the president of the province, who in a few days was to depart for Rio. Castelnau went directly to the city of Goiás (SD$-22,50-16 a)$, where he arrived on 19 March. Some days afterwards his companions arrived.

The scientific commision stayed in Goias, preparing for the planned royage to the north of the province, down the rivers Tocantins and Rraguaia. Meanwhile Weddel and Douville made an excursion to Serra Dourada (SE-22, 50-16c; \& to 17 April 1S44), near the city of Goiás.

Leaving the capital on 28 April 1844, the naturalists proceeded for only one league, when they discovered that the beasts of burden were not prepared for the trip. They had to return to Goiás, in order to reorganize the pack, and left again on 3 May.

They headed then for Crixás (SD-22, 50-14d; 8 May). where they remained for some days, Salinas (14 May), where canoes were built for the river trip. and on 10 June started down the River Crixas-Açı (SD-22. 50-15b; 50-14a: 50-14d). which they followed to the River Araguaia. Proceeding down the latter. they passed the Ilha do Bananal (SC-22, 50-11a: 49-9a), taking the right arm (Braço menor do $R$. Araguaia. SC-22, 50-10a: 5011c) of the Araguaia, passed the mouth of the Rio Chavantes ( 15 June). and reaching the confluence of both arms of the Araguaia on the 27 th. north of the llha do Bananal. After portaging many waterfalls. in their descent of the Araguaia. they reached São José dos Martirios on 9 July, after the Cachoeira Grande, and arrived at São Joāo das Duas Barras (Sāo Joāo do Araguaia. SB-22, 49-5d), at the confluence of the Araguaia and Tocantins.

In Sào João they prepared the collections to be transported to the French consul in Belem through one of the officials of São Joào who would go there down the Tocantins. However. the canoe in which the collections were being transported turned and the collections, which comprised 67 species of birds, several skins of mammals, reptiles. plants, etc., the geological collections of the Araguaia. besides weapons and utensils of the Indians of that region, were lost in the river. 
Departing from São João das Duas Barras (SB-22, 49-5d) on 20 July 1844 , the naturalists went up the Rio Tocantins, passing through Carolina (SB-23,47-7c; 11 August; the ancient village of São Pedro de Alcântara). Pôrto Imperial (Pôrto Nacional: SC-22, 48-11 a; 31 August), and Peixe (SD-22, 49-12d; 18 September). the limit of their navigation. Proceeding overland, through Amaro Leite (SD-22, 49-14a; 1 October), they headed directly to Goiás (SD-22, 50-16a), arriving on 18 October.

After having organized the collections obtained in the trip up the Tocantins, they departed on 29 October going on to Cuiabá.

Leaving Goias, they crossed the Araguaia on 14 November, entering the Province of Mato Grosso at the village of Araguaiana (SD-22, 52-16b), and went directly to the city of Cuiabá (SD-21, 56-16a). During their stay in the Capital of Mato Grosso, an excursion was made to Diamantino (SD-21, 57-14d; 20 to 25 December 1844). Daville explored several places around the capital, collecting a number of vertebrates and a considerable quantity of insects.

Leaving Cuiabá on 28 December 1844, they went to the banks of the Rio Cuiaba (SD-21. 56-16b; 56-17a), which was followed to the mouth of the Rio São Lourenço (SE-21, 56-17a; 2 February 1845). Proceeding down the Rio Cuiabá, they reached its confluence with the Rio Paraguay (4 February), and down the latter continued to Corumba (SE-21, 58-19b; $7 \mathrm{Fe}$ bruary). From Corumbá the naturalists went on to Albuquerque (SE-21,57-19c; 9 February), where they prepared the equipment necessary for a trip to Paraguay. Deville was left behind; if the dictator of Paraguay arrested the naturalists, he would go to Rio de Janciro to inform the French authorities. Castelnau knew too well what had been the treatment inflicted upon Bonpland by the dictator of that country.

Reaching Nova Coimbra (Coimbra. SE-21, 58-20b) on 11 February, they proceeded down the Paraguay River to Fuerte Olimpo (Province of Olimpo), in Paraguay. On 6 March 1845. they left that place, and sailing up the Paraguay River, went to Bahia Negra (9 March), returning to Nova Coimbra (SE-21, $58-20 b)$ and Albuquerque (SE-21, 57-10c; 16 March), following the Rio Miranda (SE-21, 57-20b), a tributary, to the city of Miranda (SE-21, 56-20c) on 28 March.

Leaving Miranda, travelling dow'n the Rio Miranda they again reached Albuquerque (SE-21, 57-19c; 17 April), and proceeded up the Paraguay Riv'er, to Vila Maria (Caceres; SE-21, 
58-16d), where they arrived on 18 May 1845. Castelnau left the collections obtained on this trip under the care of the bishop of that city, who dispatched them safely to Rio de Janeiro, from where they were afterwards sent to Paris.

Leaving Cáceres on 27 May 1845, the naturalists went to the village of Mato Grosso (SD-21,60-15d: 10 June). After a week in that city, they headed for Bolivia. After passing through Casalvasco (SD-21,60-15d; 18 June). they crossed the border on the 22nd, and proceeded by way of Santa Ana (25 June to 27). San Ignacio (SE-20, 16-61d: 28 June to 2 July). San Miguel (SE-20, 17-61b: 2-4 July). Concepción (SE-20. 16-62d: 9-11 July), and San Javier (SE-20, 16-62c: 12 July). Crossing the rivers San Miguel (16 July) and Rio Grande (21 July). they finally arrived at Santa Cruz de la Sierra (SE-20. 18-63a).

Weddel remained behind when his companions left the city on 3 September 1845, and continued his trip alone. Castelnau and the others, after bidding farewell to Weddel, proceeded along the Rio Grande or Piray. going past Sumaipata (SE-20, 18 September). Pampa Grande (SE-20, 18-64c). Chilón (SE-20. 18-65d: 14 September), and left the department of Santa Cruz. entering that of Cochabamba. Proceeding by way of Aiquilé (SE-20. 18-65c; 16 September). Chinguri (Quiroga?; SD-20, 18$-65 c)$. and crossing the Rio Grande, they entered the department of Chuquisaca, reaching the town of Chuquisaca (presently Sucre: SE-20, 19-65c), then the capital of Bolivia. on 20 September 1845 .

Departing again on 23 October, the naturalists left the Department of Chuquisaca, entering that of Potosi, reaching the capital. Potosi (SE-20, 20-66b). after 3 days travel. There they remained until 1 November 1845. when they left for Yocalla, after crossing the Rio Pilcomayo and continuing through the Department of Oruro, reaching Poopó (SE-19.18-67c) and then the city of Oruro (SE-19, 18-67a). where they met the geologist Aime Pissis (see below). who had been contracted by the Bolivian Government to inspect the mines of the region.

Leaving the city of Oruro, they went to Caracollo (SE-19. 18-67a), and entering the Department of La Paz, reached Sicasica (SE-19. 17-68d) on 13 November. After travelling through Patacmaya (SE-19, 17-6Sd). Ayo Ayo (SE-19, 17-68c) and Calamarca (SE-19, 17-68a), they arrived in $\mathrm{La} P a z$ (SE-19, 16-6Sc). After staying for some time there, the naturalists left on 2 December 1845. for Tiahuanaco (SE-19.17-69b) following along the margins of Lake Titicaca (SD-19, SE-19, 16-69c), through 


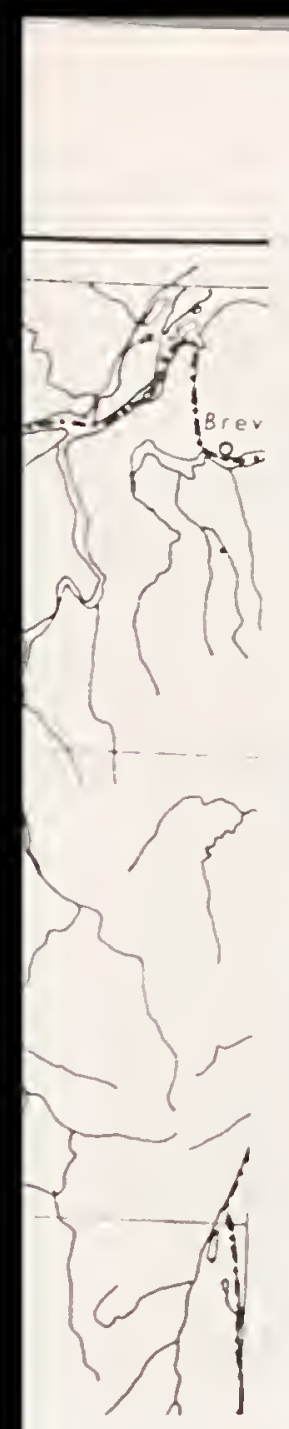

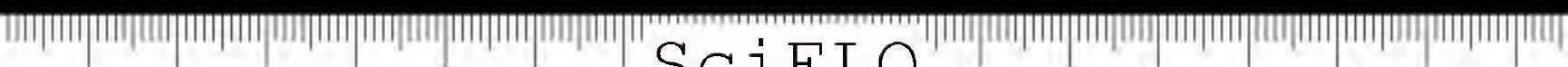

$\mathrm{cm} 1$ $\begin{array}{llllll}11 & 12 & 13 & 14 & 15 & 16\end{array}$ 17 


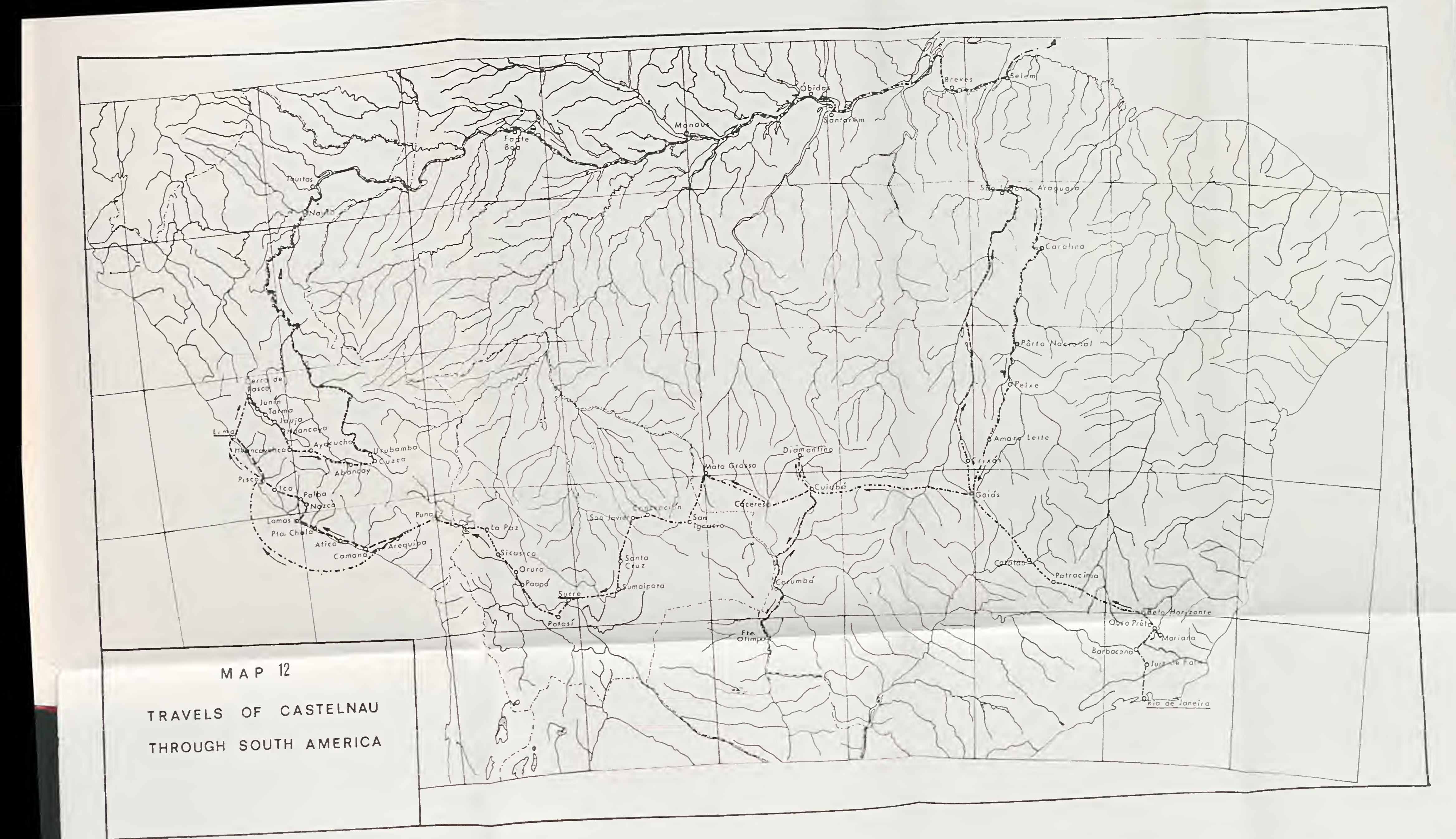


Guaqui (SE-19, 17-69b; 4 December), and Desaguadero (SE-19. 17-69a; 5 December) to enter Peru.

Through the Province of Puno, in Peru, they went through Pomata (SE-19. 16-69c; 6 December). Juli (SE-19, 16-69c). Ilave (SE-19, 16-70d: 7 December). Acora (SD-19, 16-70b; 8 December), and Puno (SD-19, 16-70a; 9-12 December), then going to Arequipa (SE-19,16-72d: 17 December), where d'Osery stayed. to follow next a different route. Castelnau and Deville left Arequipa on 23 December 1845. for Islay (SD-18, 17-72; 25 December). After 2 days at sea, they landed in Pisco (SD-18, 14-76a; Ica Province), to visit the "guano" islands; on $30 \mathrm{De}$ cember the ship arrived at Callao (SD-18, 12-77c) whence the naturalists went up to Lima (SD-18, 12-77c).

Meanwhile, d'Osery, leav'ing Arequipa (SE-19, 16-72d) on 24 December 1845, proceeded by way of Vitor (SE-19, 16-72d). Camaná (SD-18, 17-73b; 27 December). Ocaña (SD-18, 14-75d; 28 December). Atico (SD-18, 16-74d; 31 December 1845). Puerto de Chala (SD-18, 16-74a; 2 January 1846). Yauca (SD-18. 16-75b; 4 January), and Acari (SD-18, 15-75d; 5 January), all coastal localities in the department of Arequipa. Continuing by Nazca (SD-18, 15-75b; 9 January). Palpa (SD-18, 15-75b). Ica (SD-18, 14-76d; 13-16 January), Pisco (SD-18, 14-76a; 17 January), Chincha Alta (SD-18, 13-76c). Cañete (SD-18, 13-76c; 19 January). Cerro $A z u l$ (SD-18, 13-76c: 24 January), Mala (SD-18, 13-77b). Chilca (SD-18, 13-77b; 25 January), and Lurin (SD-18, 12-77d), d'Osery joined his companions in Lima $(\mathrm{SD}-18,12-77 \mathrm{c})$ on 26 January 1846.

After a stay of over three months, the naturalists left Lima on 10 May 1846 , and after eight days of royage reached Cerro de Pasco (SD-18, 16-73a) proceeding then to Junin (SC-18, 11-76d). Tarma (SC-18, 11-76d). Jauja (SC-18, 11-75d) and Huancayo (SD-18, 12-75c), in the province of Junin. Through Huancavelica (SD-18, 13-75a) and Licay (SD-18, 13-75b; Huancavelica Province). Ayacucho (SD-18, 13-74c) and Ocros (SD-18, 13-74d; Ayacucho Province). Chincheros (SD-18, 13-74d). Andahuaylas (SD-18, 1 $1-73 a$ ). Huancarama (SD-18, 14-73a) and Abancay (SD-18, 14-73b; Apurimac Province), they crossed the Apurimac River and reached Cu=co (SD-19, 14-7la).

Leaving Cuzco on 21 July, they arrived the next day at the banks of the Vilcanota River (SD-19,14-72b), in the city of Urubamba (SD-18,13-72c). There begun a difficult trip down the river. After many incidents, the naturalists were abandoned by their Indian guides. As several waterfalls remained to be 
crossed, and the margins of the river were inhabited by wild Indian tribes, Castelnau decided to send d'Osery to Lima, to leave the manuscripts and instruments in a safe place. D'Osery departed on 17 August, accompanied by Indian guides.

The remaining members of the expedition followed down the Rio Ulubamba (SC-18, 11-73a; SD-18, 12-73c), with much hardship, loss of equipment, capsized canoes, desertion of guides, hunger, incessant rains, and other trials.

On the 17th of September they passed the mouth of the River Pachitea (SC-18, 9-75d), reaching finally the village of Sarayacu (SB-18, 7-75a), the first place where they could rest, on the 28 th. Being kindly assisted by the local missionary and by the local Indians, the naturalists recovered their health, and on 9 October made an excursion to the margins of the Urubamba. to obtain fishes for the collection, using the Indian method of poisoning the waters with specific plants.

On 30 October, Castelnau decided to go on to the Marañon River, where he had arranged to meet d'Osery on his return from Lima. After going up the Ucayali River (SB-18, 6-75), the naturalists reached the Marañon, arriving in the city of Nauta (SB$-18,5-74 v$ ) on 6 November. There they remained until the 14 th, proceeding to Iquitos (SA-18, 4-73a; 17 November), and Pebas (SA-19, 3-72d; 19 November). This was where d'Osery was to meet Castelnau and Deville. During their voyage down the Ulcayali and the Marañon they had heard contradictory news about d'Osery. Some said that he had been killed by the Indians. others that he had already gone past the places visited by Castelnau. As d'Osery did not arrive in Pebas, Castelnau decided to leave on 23 December 1846, with the intention of traveling very slowly down the Amazons, thus giving d'Osery the possibility of joining him.

After a brief stay in Loreto (SA-19, 4-71c; 25 to 28 December), the two naturalists, Castelnau and Deville, entered Brazil at the city of Tabatinga (SB-19,70-4d). They left on 9 January 1847, going by São Paulo de Olivença (SA-19.69-4b), where they remained for some time. Ega (Tefé; SA-20, 65-3d; 23 January to 2 February), and still going down the Amazons they reached Manaus (SA-20,60-3c; SA-21, 60-3d) on $7 \mathrm{Fe}$ bruary. Leaving the city on the 15 th, they proceeded by Vila Nova da Rainha (Parintins; SA-21, 57-3b; 17 February), Óbidos (SA-21, 55-2a; 20 February), and Santarém (SA-21, 55-2d; 22 February), leaving the latter on the 25th. After passing by Monte Alegre (SA-21, 54-2a), they reached the mouth of the 
Rio Xingu, arriving in Breves (SA-22, 50-2a) on 5 March, Cameta (SA-22, 50-2d) on the 11 th, and after entering the rivers Tocantins and Moju, finally arrived at Belém (SA-22, 40-1d). on 16 March 1847.

Osery was not in Belém, and did not show up in the following days. Castelnau decided then to leave Belém, and on 5 April 1847, embarked on "La Thétis", arriving in Cayenne, French Guiana, on the 9 th.

On 19 April 1847 they visited Dégrad de Cannes, a small place near the $R$. Mahoury (NB-22, 5-52c) where they stayed with a certain $\mathrm{Mr}$. Gouriana. On the 20 th they went up the R. Mahoury by canoe for two hours, to the Montagnes Anglaises (NB-22, 5-52c), entering the Crique Roquemont, and proceeding overland, went to the Montagne de Gabrielle (NB-22, 5-52c). 12 leagues from Cayenne. On the 21st they left Gabrielle, returning to Cannes, through Pte. des Diamants (NB-22, 5-52c). Deville, who was feeling ill, returned to Cayenne. Castelnau and Gouriana sailed along the coast, eastwards, entering the $R$. Approuague (NA-22, 4-52a) on the same day (21 April).

4 lean the $22 \mathrm{nd}$ they visited a small establishment (Ressource). maique from the mouth of the $R$. Approuague, and also Jathey y returned to Cayenne.

take In Cayenne Castelnau found Deville so ill, that he had to be he ammediately to France, aboard "La Caravane"; in Cayenne also learned of Osery's death.

On 3 May Castelnau departed aboard the "Vigie", follo$R$ wed along the coast westward, and reached the mouth of the pa" Mana (NB-22, 6-54d). In the following day, with a "chalu$M$ an he ascended the river for 3 hours, arriving at the village of for a (NB-22, 6-54d). Thence the "Vigie" departed on 5 May Ni the River Suriname (NB-21, 5-55a). On their arrival in Fort ter Surinaterdam (NB-21, 6-55c), they asked permission to enter Surinam, which was granted, and reached Paramaribo (NB$-21,6-55 \mathrm{c})$, up river.

On 15 May, accompanied by Dutch officers, Castelnau entered the Canal Saramaca (NB-21, 6-55c), south of Paramaribo, and next the $W$ anica Creek (NB-21, 6-55c); entering the $R$. S-56 aca (NB-21, 6-56d), they arrived at Groningen (NB-21, $6-56 \mathrm{~d})$. On the following day (16 May) they continued to descend the $R$. Saramaca and, after passing Port Nassau (NB-21, $6-56 \mathrm{~d})$, where the "Vigie" was waiting for them, they entered the Atlantic Ocean, and followed the coast westwards, arriving at Georgetown (NB-21,7-58c) on the R. Demerara on 19 May. 
On 26 May 1847, Castelnau left Georgetown, aboard the sloop "Elisabeth", going to Barbados (ND-20, 13-60b), where he remained until the 9th of June. On 10 June landed at Saint Lucia (ND-20, 14-61c), and on the 12th at Saint Pierre, Martinique (ND-20,15-16c), remaining there until the 15 th, when he sailed to the capital, Fort-Royal (now Fort-de-France, ND-20, 15-61c). Castelnau remained in Fort-Royal until 24 June 1847. when he made an excursion to Gros Morne (ND-20, 15-61c), arriving in Trinite (ND-20,15-61d), on the eastern side of the island. Following northwards along the coast, by Sainte-Marie (ND-20, 15-61d), he entered the interior of the island, through Mont Pelée (ND-20, 15-61c), reaching once more the western side of Martinique at Saint-Pierre (ND-20, 15-61c), whence he returned to the capital.

On 27 July he embarked again, and passing by Dominica (ND-20, 15-62b), reached Basse-Terre, capital of La Guadeloupe (ND-20, NE-20,16-62d). On the 28th he passed by Antigua (NE-20, 17-62b). Montserrat (NE-20, 17-62c), and Saint Christopher (Saint Kitts; NE-20, 17-63b). On the 28th he went by Tortola (NE-20, 18-65b), in the Virgin Islands, and St. Croix (NE-20, 18-65d), landing finally on the 30th at the bay of St. Thomas (NE-20, 18-65b). After 3 days, he embarked aboard the steamer "Forth", which after 14 days reached the Azores, and 7 days later Southampton. On the same day Castelnau departed for Le Havre, and, via the railroad constructed during his long absence, entered Paris on 25 July 1847.

France was going through difficult times, due to the revolution. Castelnau left his country once more, and traveled to Salvador, Bahia, Brazil, as French Consul. There he wrote a report on his trips, in collaboration with the other members of his expedition. The monumental work, "Expédition dans les parties centrales de l'Amérique du Sud, de Rio de Janeiro à Lima, et de Lima au Pará" was printed in Paris from 1850 to 1857 , in 15 volumes. The first 6 contain the history of the voyage, and the others descriptions of landscapes and sceneries, Inca antiquities, itineraries and geological observations, geography, botany, and zoology.

From Salvador, he went as consul to the Cape of Good Hope, and then to Siam, remaining in Bangkok until 1862, returning to France with rich collections and voluminous notes. His intention was to organize the notes and publish them as a book of travels, as he had done during his stay in Salvador. But to his sad surprise, he discovered that his servant had used his papers to light the daily fire. 
Castelnau gave his collections to the Paris Museum, and the remaining notes and drawings to Lacordaire, except those on the Coleoptera, which he took with him to Melbourne, where he had been appointed French Consul. There he remained for the rest of his life, and published several papers. As his collections were always increasing, he could no longer keep them and sent all the specimens to Paris, where they were separately sold. Two years before his death he had retired and decided to remain in Australia, where death caught him in 1880 (Enc.; Castelnau, 1850-57, 1949; Garcia, 1922; Pereira, 1935).

\section{A. Pissis}

PIERre J. NoËL AIMÉ PISsIS was born in Brioude, Haute-Loire, on 17 May 1812. His father was the medical doctor Pierre Joseph Pissis. His first studies were made in his native town, where he went to the "Lycée Charlemagne". In 1830 he entered the Polytechnic School, and soon acquired fame as a geologist.

His first voyage to South America was made to Brazil (around 1841), to study the geology of the country. According to his geological memoirs (1842a-d, 1888), and to Leinz (no date: 248), his travels in Brazil were limited to the neighborhood of Salvador (SD-24, 38-13c), Bahia, and Rio de Janeiro (SF-23, 43-23a). From Rio de Janeiro he travelled to Ipanema (SF-22, 48-24a), in São Paulo (for itineraries see Chapter V), and to Ouro Prêto (SF-23, 44-20d) and Sabará (SE-23, 44-20b) in Minas Gerais (see also Chapter V). He also used his time in Brazil to study the fauna and the flora.

In 1846 he was employed by the Government of Bolivia to map the country, a task which was left unfinished due to political disturbances. On that occasion he met Castelnau in Oruro, as we have seen.

Leaving Bolivia, he proceeded to Chile in 1848, also employed by the Government to study the geology and mineralogy of the country; there he remained for 20 years $(1848-1867)$. During his long stay in Chile he sent to Paris valuable collections of insects, which were studied by Macquart and Bigot.

He published a book on the geography of Chile (1875), with a chapter on the Chilean fauna (pp. 293). In 1854 the French Government awarded him the "Légion d'Honneur". He occupied for many years the position of head of the geographical 
section of the "Oficina Central de Estadistica" of Chile, and died in Santiago on 21 January 1889, after more than 40 years of service to Chile (Porter, 1903a).

\section{P. Germain}

Philibert Germain was born in Lyon, France on $25 \mathrm{Ja}$ nuary 1827. It is said that he could read at the early age of 4 , and that at 8 he was much beyond his contemporaries, deserving a place in a school. There he remained for 5 years, moving then to a State School, where in two years he finished the study of "humanities". In 1842 he was ready to graduate, but as the law forbade this before the age of 16 (Germain was 13 years old then), he had to wait, and used his time to study ornithology and entomology. His interest in insects came from a book about the insects of France, which his father had given him when he was 11.

In 1853 he embarked for Chile, with a letter of recommendation to Gay, who obtained a job for him in the Museum. Soon afterwards he was made director of the National Museum of Santiago, occupying this post for only a few months. On his arrival, R. Philippi was appointed director of the institution, and Germain became the vice director, occupying this position until 1858, when he left the museum to undertake several zoological expeditions.

For some years he taught at the "Liceo de Quillota", returning to the Museum of Santiago only in February 1903, as head of the entomological section. In 1892 he was appointed member of the Sociedad Cientifica de Chile, and the French Government, through its Ministry of Agriculture, granted him, in 1902, the Cross of Agricultural Merit.

Germain dedicated 50 years of his life to Chile. $\mathrm{He}$ is better known as a coleopterist, having published numerous papers with L. Fairmaire, from 1858 to 1862 , in the Annales de la Société Entomologique de France. All his collections were eventually sent to the Paris Museum.

Germain explored practically all of Chile, from Tarapacá to Magallanes, but no information is available about his itineraries. He left a short account (1891b), of his excursion to the Cordillera de Chillan. He also seems to have visited the Amazons, and in 1887 visited Mato Grosso, in Brazil. According to his brief report (1891a) he arrived to Cáceres (SE-21, 58-16d), in Mato 
Grosso, aboard the "Tereré" (which sailed between Corumbá and Cáceres), on 4 August 1887. Three weeks later (1 September) entered the R. Sipotuba (SD-21, 58-14d, 58-16b) and twelve days later reached the mouth of the Jutubeba, from where he returned, after 15 days, to Cáceres.

In 1899 (?) he visited Corunbá (17 September), Piedra Blanca, Santa Ana (26 September), San Carlos (2 October), and San José (6 October), reaching Santa Cruz de La Sierra on October 12, after 22 days of voyage. About this trip he wrote two small and uniformative articles (1900a, 1900b).

According to Porter $(1903,1913)$ he then went down the Paraguay, arriving at Buenos Aires, whence he returned to Chile. Porter (1930b) lists also among Germain's writings an account of his travels from Asunción to Mollendo, which I have not been able to locate.

Labels of Coleoptera in the Paris Museum indicate that Germain also collected in Rio de Janeiro (1884), in the Serra do Caraça. Minas Gerais (VII-XII.1884), on the Rio Piracicaba, Minas Gerais (II.1885), in Mato Grosso (1886), and in Cochabamba, Bolivia (1889). Germain died in Chile on 9 December 1913 (Porter, 1903b).

\section{M. de Mathan}

Nothing is known about the life of Marc de Mathan. From labels on specimens of Cerambycidae belonging to the Museum National d'Histoire Naturelle de Paris, the following information has been extracted (kindly supplied by Ubirajara R. Martins). He went up the Amazons River, from Belém (SA$-22,49-1 d)$ to Tefé (SA-20,65-3d), in the State of Amazonas, there staying from January to June and October to November 1879. The next date is from São Paulo de Olivença (SA 19, $69-4 b)$, also in the State of Amazonas, where he was during the month of May 1883. He must have proceeded then up the Marañon and its tributaries, to Caballococha (SA-19, 4-70a), Peru (May to August 1884), then to Chambiruyaca (near Yurimaguas, SB-18,6-76a), R. Huallaga, Peru (June to August 1885). Tarapoto (San Martin; SB-18, 7-76a), Peru (October to December 1885, May to August 1886). Moyobamba (San Martin; SB$-18,6-77 d$; January to June 1887), and thence to Ecuador, arriving at the Rio Chimbo (SA-17, 2-80d), whence we have labe!s dating from 1891. In 1893 we have labels from Balzapamba 
(SA-17, 2-79a), "route de Quito", and Bolivar (SA-17, 2-79a). Ecuador (September-October); again from the same place, March to April 1894. The next label tells us that from January to June, 1900, he was in Canache (?), Cundinamarca. Colombia. It is not known whether he spent all these years in South America, or visited those countries at intervals, returning to France between times.

\section{P. E. Gounelle}

Pierre Émile Gounelde was born in Paris on 9 June 1850. His father was the engineer Eugene Gounelle, who directed in 1844 the works of the first French telegraph lines between Paris and Rouen and between Rouen and Havre.

As an employee of the "Ministère des Colonies". Gounelle royaged to Indochina in 1873, but his health did not permit a long stay there, and he soon returned to France. He began then to work seriously on entomology. and joined the French Entomological Society in 1878 .

From 1884 to 1914 he undertook seven voyages to different points of Brazil, bringing home valuable collections, sent afterwards to the Paris Museum.

The data on his voyages are also somewhat incomplete:

I. 1854: Rio de Janeiro (SF-23, 43-23a), State of Guanabara: Gounelle collected especially in the forests of Tijuca. Proceeding then through the Serra dos Orgāos, crossing the Rio Paraibuna, and going through several cities of Minas Gerais (see Chapter $V$ for itineraries), he reached the Serra do Caraça on 1 January 1885 (see Bull. Soc. Ent. France 1885: xxxvii), staying there until February of the same year. From March to April 1885 we find him collecting in Matozinhos (SE-23, 44-20a). Minas Gerais. The next month he was at Terra Nova, Bahia, and then in Salobra, also in the State of Bahia, where he remained from June to July 1885. He then returned to France.

11. His second collecting trip in Brazil was to Santo Antōnio da Barra, State of Bahia, from $18 s S$ (on the labels "November-December") to 1589.

III. From May to June 1592, in Peri-Peri (Municipio de Quipapá SC-24, 36-9a). State of Pernambuco. In this place he stayed from November to December 1892, going in January 1893 
to the Serra de Comunati, Mun. Águas Belas (SC-24, 37-9c), Pernambuco, and there remaining until March.

IV. In 1895 he explored the Serra de Baturite (SB-24, 39-4C) (January), and Marco da Légua (presently inside the city of Belém) and Benevides (SA-22,48-1c), in the State of Pará (10 February to 10 March 1895) (see also Bol. Mus. Paraense 2: 70-77).

V. His wanderings during 1897 took him to the Canary Islands, and then, in 1898-99, to southern Brazil. He visited Ribeirão Pires (SF-23, 46-24a; November, 1898), and Cerqueira César $(\mathrm{SF}-22,49-23 \mathrm{c}$ ), in the State of São Paulo (November-December 1898), proceeding next to the State of Rio de Janeiro, where he explored the Serra do Itatiaia (SF-23, 45-22d; February 1899). arriving in Rio de Janeiro (SF-29, 43-27a). State of Guanabara, in February 1899, and then going for a second time to the Serra do Caraça, in Minas Gerais (March to May 1899).

VI. In 1901 he traveled again to the Canary Islands, and returned once more to Brazil, landing at Rio de Janeiro and proceeding through Minas Gerais to Diamantina (SE-23, 44-18d; for itinerary see voyage of Saint-Hilaire, in the beginning of this chapter). Returning to Rio, he visited then the city of Nova Friburgo (SF-23, 43-22d, on the Serra dos Órgãos; February to May 1903), and visited again the Serra do Caraça, Minas Gerais (June 1903).

After returning to Europe from this voyage, his health was impaired, and he hesitated for a long time before departing for his last voyage to Brazil. He finally decided to leave France in November 1913, and came to the State of Santa Catarina. There he acquired a disease and had to return to France in March 1914. He was so hurt by the beginning of the World War I that his disease much worsened, and he died on 2 October 1914. (Milot, 1920).

\section{A. Rojas}

Marco Aurelio Rojas was born in Caracas, Venezuela, on 10 April 1831. His father was the economist José Maria Rojas, from the Spanish part of the Island of Santo Domingo (now Dominican Republic), who had come to live in Caracas for some years. There he had opened a book-shop, where the boy read his first natural history books. Marco Aurelio Rojas 
made his basic studies in Caracas, and there he graduated in medicine. In Caracas also he met Auguste Sallé, and then took a special interest in entomology. When Sallé left Venezuela. Rojas employed a collector, who explored the surroundings of $\mathrm{Ca}$ racas (NC-19,11-67d): the collections thus obtained were sent to Sallé. Rojas was elected fellow of the French Entomological Society in 1851, remaining as a member until 1864 . He had a special liking for Coleoptera, and published several papers on the group in the Annals of the Society.

At the age of 24 he became a doctor in medicine. Leaving the parental home, he went to San Fernando de Apure (NB-19. $8-67 \mathrm{c})$. where he remained for 16 months. Returning to Caracas in May 1856, he got cholera, during an epidemic. After recovery, he went to New York and Philadelphia to visit his brothers. Next he went to Le Havre and Paris, where he arrived in September. He remained in the city for $t$ wo years, studying at several hospitals, and then left for London, remaining in England for a year working at the schools of Edinburgh and Dublin. Returning to Paris, he left then for New York, which he reached in April 1859.

Having decided to establish himself in the United States. he went to New Orleans in January 1860 , but, fecling himself unable to stand the unhealthy climate, embarked to Cuba, and established himself at Cienfuegos. where he practiced medicine for about $\&$ years. On 21 May 1863, he received a prize from the Royal Academy of Medical Sciences of Havana, for his medical works. In December 1864, he left Cienlugos to go to New York, where he died from scarlet fever on 17 June 1866 at the age of 35 (Sallè, 1866).

\section{Other collectors}

In addition to the above collectors, some other names must be cited about whom we have very scant or no information at all.

Of LeBAS we have only a short note given by Reiche (1843: 238). that he collected in Colombia (Santa Fé de Bogotá and other areas) and Ecuador, around 1830.

Of Hogard (or Hodgard). and ot BeAupertuis, who collected in Guadeloupe in 1839 (Urban, 1903: 20) and are cited by Robineau-Desvoidy and Macquart, we know nothing.

Macquart also cites a "FonTAive" (or Fontaines), who co!lected in Chile and Peru. A "Fontaine" is cited by du Petit- 
-Thouars, in his relation of the voyage of the frigate "La Vénus" (1840-43).

Pierre Antoine Fontana, "dit Fontaine", was "capitaine d'armes de première classe", aboard the frigate "La Vénus", commanded by du Petit-Thouars. The frigate left Brest on 29 December 1836 for Teneriffe (9 January 1837), and then for Fernando de Noronha (SB-25, 33-4b), and Cabo Frio (SF-23. 42-23a; SF-24, 42-23b; 3 February). The frigate landed in Rio de Janeiro (SF-23, 43-23a), staying there from 4 to 16 February, going afterward to Florianópolis (SG-22, 48-28a). Montevideo (SI-21, 35-56a; 24 February), Buenos Aires, Cape Horn, and Valparaiso (SI-19, 33-72d; 27 March), whence some of the members of the expedition followed to Santiago (SI-19. 33-71d), overland. Leaving Valparaiso on 13 May, they visited the Island of San Gallán (?), and the Island of San Lorenzo (?). then Callao and Lima (SD-18, 12-77c), in Peru. Next they returned to Callao (SD-18, 12-77c: 14 June), and from there departed for the Sandwich Islands and other places, returning afterwards to Monterey. California.

They then explored the localities of Guadalupe (?) (19 November 1837). Bahia de Magdalena (NG-12, 25-11d), San Lucas (?). San Pedro del Cabo (?). Isla Venado (?). Mazatlán (NF-13, 23-106a). Golfo de Cortez (?). Isla Isabel (NF-13, 22-106b). San Blas (?). Tépic (NF-13, 22-105d), and Acapulco (NE-14, 17-101d). Proceeding to the Easter Island, they returned next to the South American Pacific coast, touching the Juan Fernaindez Islands, and landing in Valparaiso (SI-19, 33 72d). They visited the Islas Desaventuradas (?), I. San Ambrosio (SI-18, 26-80d). I. San Félix (SI-18, 26-80a). Callao (SD-18. 12-77c). Isla Hormigas (?), Paita (SB-17. 5-81c). San Miguel de Piura (?), Colán (SB-17, 5-81c), and Galápagos (21 June). and on 15 July 1838, departed for the Marquesas (du Petit-Thouars, 1840-43).

However, no referente is made by Petit-Thouars to "Fontaine" as a zoological collector, credit being given to the ship surgeon, Adolphe Simon Néboux, "chirurgien de première classe". who sent collections of animals, especially birds and insects, to the Paris Museum. Thus, we cannot be sure whether the "Fontaine" cited by Macquart is the same as the one who participated in the "La Vénus" expedition.

Of Justix Goudot, who collected extensively in "Nueva Granada" (Colombia), we have very meagre information. He seems to have come to Colombia with two other naturalists, Jean 
Baptiste Joseph Dieudonné Boussingault, and François Désiré Roulin. Boussingault came to Colombia to investigate old, abandonned mines, that would be reexplored by an English company. Boussingault stayed in the country for many years. Roulin taught physiology in Bolivia, and to make a living undertook the topographic mapping of the country, according to a wish of Bolivar.

Goudot collected in the Magdalena Valley and other regions of Colombia. With Boussingault and Roulin he visited the regions of Cúcuta, Pamplona, Santa Rosa, Tunja and Bogotá, from 1822 to 1823 . In 1824, he collected in the "llanos" of San Martin and then down to the mouth of the Rio Meta. He travelled afterwards with a Peruvian, Rivero. to the areas of Bogotá and Vélez, and in 1825 to Mariquita. the "paso" of Herveo up to Supia, and to the provinces of Antioquia, Popayán and Tolima (Medem, 1969).

Goudot seems to have had his headquarters in Bogotá, and to have employed Indians and other collectors. He may have served as an intermediary between professional collectors in Colombia and handlers of natural history materials in several European countries. He spent 15 years in Colombia, returning to Paris in 1843. with rich collections. Later he returned to Colombia. and there he died (Stresemann, 1951: 389).

Pierre Bouchard collected in New Grenada (Colombia). especially around the Santa Marta region (Pascoe, 1866). No other details are available to me.

Mme. Rrotre collected in French Guiana (La Mana), and Martinique. In the Paris Museum accession book (Cataloque des animaux sans vertèbres), two entries, p. 127 (1837), of Vol. 1. p. 233 of Vol. 2 (1840), and p. 179 of Vol. 3 (1841) refer to her name, also as "Mme. Rivoire Theodosie".

\section{References}

Anonymous

1533. [Notice sur les voyages de M!. Lepricur]. Ann. Soc. Ent. France 2 (Bull.) : 27 . Lxrvm.

1870. [Lacordairc. biographical rote]. Trans. Ent. Soc. London 1570 (Proc.) : XLV'-XLVT?.

Araca Diaz. S.

1960. Viaje de La Coquille y expedición antarcica belga. Publ. Ceniro Est. Enh. Sartago 2 : 227-236.

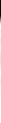


Barral, J. A.

1857. Ocuures complètes de François Arago, sécrétairc perpétucl de IAcadémic des Sciences 9: 644 pp. Gide Editeur, Paris \& T. O. IVeigel, Editeur, Leipzig.

Barros Araña, D.

1876. Don Claudio Gay. Su vida, sus obras. Anal. Univ. Chile 49 : 5-227. (Also separatcly published, 235 pp., Santiago).

Blake. A. V. A. Sacrantento

1895. Diccionario bibliographico brazilciro 4 : 529 pp. Imprensa Nacional. Rio de Janeiro.

Bougainville, 11. Y. P. P.

1837. Journal de la navigation autour du globe de la frégate 'La Thétis' et de la corvette 'L'Espérance', pendant les années 1824, 1825 ct 1526, publiéc par ordre du roi, sous les auspices de la marine 1 : vII +742 pp.opls.: 2 (1) : xvI +351 pp.; 2 (2) : 165 pp. Arthus Bertrand, Librairc-Editeur, Paris.

Castelnau, F. de

1850-57. Expédition dans les partics centrales de l"Amérique du Sud. de Rio de Janeiro à Lima, et de Lima ar Para, crecutéc par ordre du gouvernement français pendant les années 1843 à 1847 .

1 (Histoire du voyage, 6 vols.); 2 (Vues et scènes) : 485 pp.;

3 (Antiquités des Ineas) : 483 pp.; 4 (1tinéraires) : 467 pp.;

5 (Géographic) : 478 pp.: 6 (Botanique) : v1 +439 pp., 1 map;

7 (Zoologie).

1949. Expedição às regiốcs centrais da América do Sul 1 : 383 pp.; 2 : 379 pp. (Biblioteca Pedagógica Brasileira, Série 5, Brasiliana, vols. 266, 267). Companhia Editora Nacional, São Paulo.

Crcvaux, J.

1883. Voyages dans [Amérique du Sud, xu +635 pp., 235 figs., 4 maps. Hachettc \& Cie., Paris.

Debret, J. B.

1940. Viâgem pitoresca c histórica ao Brasil 1 : 295 pp., 49 pls., 1 portrait, 1 map. (Biblioteca Historica Nacional, vol. 4). Livraria Martins, São Paulo.

Etcheverry Campaña, E.

1960. Viaje de La Favorite, La Bonite y Lastrolabe y La Zelée, Publ. Centro Est. Ent., Santiago 2 : 239-251. 
Freycinet, L. C. D. de

1828. Voyage autour du monde, entrepris par ordre du roi, sous le ministère et conformément aux instructions de S. Exc. M. le Vicomte de Bouchage, sécrétaire deétat au département de la Marine, exécuté sur les corvettes de S. M. lOOranic et la Physicienne, pendant les années 1517, 1815, 1819 et 1820,1 (1): xit + 311 pp.: 1 (2) : 343-734; 2 : 515 pp. Pillet Ainé. Imprimeur-Libraire, Paris.

Garcia, R.

1922. Historia das explorações scientificas, pp. 856-910, in Instituto Historico, Geographico e Ethnographico Brasileiro, Diccionario Historico. Geographico e Ethnographico do Brasil 1 : 1688 pp.. illus.

Germain, P.

1892a. Trois mois dans la vallée du Sipotuba (province de MattoGrosso, Brésil). Act. Soc. Scient. Chili 1 (1891) : 53-65.

1892b. Une excursion entomologique dans la Cordillère de Chillan. Act. Soc. Scient. Chili 2 : cLxv-CLxvut.

1900a. De Corumbá a Santa Cruz de la Sierra. Act. Soc. Scient. Chili $10: \$-52$.

1900b. La Bolivie Orientale. La Prefecture de Santa Cruz de la Sierra. Act. Soc. Scient. Chili $10: 318-378$.

Girard, M.

1868. Notice nécrologique sur la vie et les travaux scientifiques ¿'Adolphe Doumerc, docteur en médécine, membre fondateur de la Société Entomologique de France. Ann. Soc. Ent. Frarce (4) $S: 885-892$.

Hoehne, F. C

[19-2]. Notas bio-bibliograficas de raturalistas botánicos, in F. C. Hochne, M. Kuhlmann E O. Handro, O Jardim Botảnico de Săo Paulo, 656 pp.o illus. São Paulo.

Lacerda, J. B.

1905. Fastos do Museu Nacional do Rio de Janeiro. Recordaşes historicas e scientificas fundadas $\mathrm{cm}$ documentos authenticos c informaç̌es veridicas. $\mathrm{N}+189 \mathrm{pp}$. Imprensa Nacioaal, Rio de Janeiro. 
Lacordaire, J. T.

1830. Mèmoire sur les habitudes des coléoptėres de l'Amérique méridionale. Ann. Sci. Nat. 20 : 185-291; 21 : 149-194.

1832. Notice sur l'entomologie de la Guyane Française. Ann. Soc. Ent. France 1 : 348-366.

1833a. Notice sur les habitudes des lepidptères rhopalocères (diurnes) de la Guyane Française. Ann. Soc. Ent. France 2 : 379-397.

1833b. Essai sur les Coléoptères de la Guiane française. Nouv. Annal. Mus. Hist. Nat. Paris $2: 35-97$.

Ladislau Netto, (-)

1870. Investigaçōes historicas e scientificas sobre o Museu Imperial e Nacional do Rio de Janeiro acompanhadas de uma breve noticia de suas colleç̧óes e publicadas por ordem do Ministerio da Agricultura. Iv $+310+x$ pp. Instituto Philomatico, Rio de Janeiro.

Laplace, C. P. T.

1833. Voyage autour du monde par les mers de l'Inde et de Chine exécuté sur les cortettes de l'état La Favorite pendant les années 1830. 1831. et 1832, 1 : xIr + 588 pp., 1 map; $2: 481$ pp.; 3 (1835) : 510 pp.; 4 (1835) : 480 pp. Imprimérie Royale, Paris. (Albun historique, par M. de Sainson, 1835 : 72 pls., Arthus Bertrand, Paris).

La Salle, A. de

1845-53. Voyage autour du monde exécuté pendant les années 1836 et 1837 sut la corvette La Bonite commandée par $M$. Vaillant, Capitaine de Vaisseau, publié par ordre du roi, sous les auspices du départément de la marine. Rélation du voyage 1 : xv +478 pp.; 4 pls.; 2 (1851) : 414 pp.; 3 (1852) : 540 pp. Arthus Bertrand. Paris. (Album historique [no date], 100 pls.).

Leinz, V.

(no date). A geologia e a palentologia no Brasil, pp. 245-263, in F. de Azevedo, ed., As ciências no Brasil 1 : 412 pp., illus. Companhia Melhoramentos, São Paulo.

Lesson, P.

1838. Voyage autout du monde, entrepris pat ordre du gouvernement sur la corvette La Coquille 1 : 512 pp., pls. P. Pourrat Frères, Editeurs, Paris.

Medem, F.

[1969]. El desarrollo de la herpetologia en Colombia. Rev. Acad. Colomb. Cienc. Exactas, Fisicas y Naturales 13 (50) (1968) : 149-199, 2 tables, 13 figs., 1 map. 
Milot, A.

1920. Notice nécrologique sur P.-E. Gounelle. Ann. Soc. Ent. France S9 : 109-112.

d'Orbigny, A. D.

1835-1847. Voyage dans l'Amérique Méridionale (le Brćsil, la Réptıblique Orientale de l'Uruguay. la République Argentinc, la Patagonie, la République du Chili. la République de Bolivia, la République du Pérous). exécuté pendant les annécs 1826. 1827. 1828, 1829. 1830, 1831. 1832, et 1833. 1 (1835) : Partie Historique; 2 (1839-1843) : Partie Historique [cont.]; 3 (1) (1844): Partic Historique [concl.]: 3 (2) (1846) : Géographie: 3 (3) (1842) : Géologie; 3 (4) (1842) : Paléontologic: 4 (1) (1839) : L'Homme Américain; f (2) (1847) : Mammiféres: 4 (3) : Oiseaux: 5 (1) (1847) : Reptiles: 5 (2) (1847) : Poissons: 5 (3) (1835-1843) : Mollusques: 5 (4) (1839 and 1846): Zoophytes; 5 (5) (1839) : Foraminifères; 6 (1) (1843) : Crustacés: 6 (2) (1837-1843) : Insectes: 7 (1-2) (1539) : Cryptogamie: 7 (3) (1847) : Palmiers; 8 : Atlas historique, géographique, géologique, palẻontologique et botanique: 9 : Mammifères, crustacés, et insectes. Pitois-Levrault \& Cie.. LibrairieEditeurs, Strasbourg: [Vols. 2, 3. $4(1) .5$ and 9] P. Bertrand. Paris \& Ve. Lerrault, Strasbourg.

1853. Voyage dans les deux Amériques, augmenté de renscignements exacts. jusqu'cn 1553 sur les differents etats du noureau monde, $n+615$ pp., illus.. pls. 2 maps. Furne $\&$ Cic., Libraires-Éditcurs. Paris.

1945. Viaje a la America Mcridional. Brasil - República del Uruguan - República Argentina - La Patagonia - Republica del Chile República de Bolivia - República del Peru. realiaado de 1526 a 1533. $1: 439$ pp.: 2 : 449-816: 3 : 825-1232: 4 : 1241-1614. illus. (+ Indice yeograflico estadistico, historico de las matcrias conteridas en los quatro tomos, $35 \mathrm{pp})$. Editorial Futuro. Buenos Aires.

Pascoe, F. P.

1S66. List of the Longicomia collected by the late Mr. P. Bouchard at Santa Matta. Trans. Ent. Soc. London (3) $5: 279$.

Penrell. F. W.

1945. Historical sketch, pp. 35-49, in F. Verdoorn, cd.. Plents and plani sciences in Latin America. Xxxvry + $3 \$ 1$ pp. Chronica Botanica Co., Waltham, Massachusetts.

Pereira, C.

1935. Castelnau e o Brasil. Bol. Biol. (N.S.). Săo Paulo 2 (3) : \$4-95.

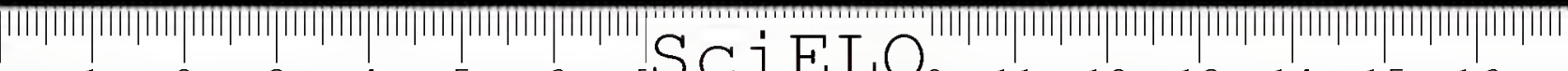
$\mathrm{cm} \quad 1$ 2 3 5 6 
Petit-Thouars, A. A. du

1840-43. Voyagc autour du mondc sur la frégate La Vénus, pendant les années 1836-1839, publiéc par ordre du roi, sous les auspices $d t$ ministère dc la marine I (1840) : XLrv + 402 pp., 2 pls.; 2 (1841) : 464 pp.; 3 (1841) : 490 pp.. 6 pls.; 4 (1843) : 178 pp., 1 pl. Atlas Pittoresque, 68 pls.

Pissis, A.

1842a. Considérations générales sur les terrains du Brésil. Bull. Soc. Géol. Francc (1) $13: 289-290$

1842b. Mémoire sur la position géologique des terrains de la partie australe du Brésil, et sur les soulevements qui, à diverses époques, on changé le relief de cette contrée. C. R. Acad. Sei. Paris $14: 1044-1046$.

1842c. [Mémoire presentéc par Cordier, Beaumont et Dufresnoy]. Mćm. Acad. Sci. Paris $10: 353-413,2$ maps, 8 pls.

1842d. Notice gėognostique sur la Province de Rio de Janeiro. Ann. Sei. Géol. (Arch. Géol.) 1 : 224-249.

1888. Memoria sobre a estructura geologica dos terrenos da parto austral do Brasil e sobre as solevaçōes que em diversas epocas modificaram o relevo do solo desta região. Rev. Trimestr. Inst. Hist. Geograf. Etthogr. Brasil. 51 (2) (Suppl.) : 147-151.

Plée, A.

1820-1825. Catalogue des divers objets qui composent non prcmicr envoi au Muséum d"Histoirc Naturelle (Fort Royal, ile Martinique, 31 juillet 1920). Signé dc l'auteut, avee un supplément. (MS 71.I) $76 \mathrm{pp}$.

- Supplément. (MS 71.II), 16 pp.

- Sccond envoi (MS 71. II1), $76 \mathrm{pp.}$

- Troisieme cnvoi (1S mars 1821), (MS 71.IV), 33 pp.

- Liste des poissons de la Martinique envoyés au Muséum, (MS TI.V). $15 \mathrm{pp}$.

- $6^{n}$ partic de la collection [d"Aug. Plée], 2n séric. Cahier d"analyscs ou d'cxamen des animaux, des végetaux et minéraux, (1S24-1S25). (MS 71.VI), $220 \mathrm{pp}$.

- Poissons de la Guaira. (MS 71.VI1), 11 pp. (320 x $195 \mathrm{~mm}$, Bibliothéque du Muséum National d'Histoire Naturelle, Paris).

(no date). Catalogue des eollections d'Auguste Plée conscrvées dans Ialeool - Zoologic en général, mammifères, oiseaux, rcptiles, poissons de Puerto-Rico et de la Cöte Ferme, vers, zoophytes, (MS 72) 362 fls. (330 × $200 \mathrm{~mm}$, Bibliothèque du Muséum National d'Histoire Naturelle, Paris). 
(1822-1823). Atlas. Recueil de vues ou esquisses faites pendant le voyage. Dessins, en général au crayon, relatifs sux Petites-Antilles, à la Côte-Ferme, à l'île de Porto-Rico (1822-1823), aux ÉtatsUnis et au Canada, (MS 73), 277 fls. (410 x $310 \mathrm{~mm}$, Bibliothèque du Muséum National dHistoire Naturelle, Paris). [MS bound in 3 vols.].

Porter, C. E.

1902. Don Claudio Gay, notas biográficas i bibliográficas. Rev. Chil. Hist. Nat. 6 (3) : 109-132, pl. 3.

1903a. Galeria de naturalistas de Chile. Don Amado Pissis. Rev. Chil. Hist. Nat. 7 : 201-202, portrait.

1903b. Galeria de naturalistas de Chile. Don Filiberto Germain. Notas biográficas i bibliográficas. Rev. Chil. Hist. Nat. 7 : 249-253. pl. 14.

1913. Don Filiberto Germain, fallecido el 9 de Diciembre de 1913. Rev. Chil. Hist. Nat. $17: 245-255$, portrait.

Reiche, L.

[1843]. Colḱopteres de Colombie. Rev. Zool. 5 : 235-242.

Reyes Bianchi, R.

1960. Colecta entomologica y relación de los viajes de d'Orbigny y del Alert a Chile. Publ. Centro Est. Ent. Santiago 2 : 255-263.

Saint-Hilaire, A.

1822. Aperçu d’un voyage dans l'intéricur du Brésil, la Province Cisplatine et les Missions dites du Paraguay. Mém. Mus. Hist. Nat. Paris 9 : 307-380.

1823. Rapport sur le voyage de M. Auguste de Saint-Hilaire dans le Brésil et les missions du Paraguay lu a TInstitu: de France. Académic Royale des Sciences, 8 pp. Impriméric de J. Smith, Paris.

1830. Voyage dans les Provinces de Rio de Janeiro et de Minas Gerais, 2 vols. $x w+458$ pp., and 478 pp. Grinbet $\&$ Dorez, Paris (Voyages dans l'intérieur du Brésil, Première partie).

1538. Voyages dans le dissrict des diamans et sur le litsoral du Brésil. suivi de notes sur quelques plantes caractéristiques et $d$ un précis de Thistoire des sévolutions de TEmpire Brésilien, depuis le commencement du règne de lean VI jusquis rabdication de $D$. Pedro I : xox + 402 pp.: 2 : 456 pp. Gide. Parts. (Voyages dars lintériuer du Brésil. Seconde partie). 
1847-48. Voyages aux sources du Rio de S. Francisco et dans la Province de Goyaz 1 : 347 pp.; 2 : 380 pp. Arthus Bertrand, Paris (Voyages dans l'intérieur du Brésil, Troisième partie).

1851. Voyage dans les Provinces de Saint-Paul et dc Sainte-Catherine I: vi + 464 pp.; 2 : 423 pp. Arthus Bertrand, Paris (Voyages dans l'intèrieur du Brésil, Quatrième partie).

1887. Voyage à Rio Grande do Sul (Brésil), vin + 645 pp. H. Herluison, Orléans.

1936a. Viagem à Provincia de Santa Catharina (1820), 252 pp. (Biblioteca Pedagogica Brasileira, Série 5, Brasiliana, vol. 58). Companhia Editora Nacional, Săo Paulo.

1936b. Segunda viagem ao intcrior do Brasil, Espirito Santo, 245 pp. (Biblioteca Pedagogica Brasileira, Sërie 5", Brasiliana, vol. 72). Companhia Editora Nacional, São Paulo.

1937. Viagcm às nascentcs do Rio S. Francisco c pcla Provincia de Goyaz 1 : 341 pp.; 2 : 306 pp. (Biblioteca Pedagogica Brasileira, Série 5". Brasiliana, vols. 68, 78). Companhia Editora Nacional, São Paulo.

1938a. Segunda viagem do Rio de Janeiro a Minas Gcrais e a São Paulo (1822), 222 pp., pls. (Biblioteca Pedagógica Brasileira, Série 5*, Brasiliana, vol. 5). Companhia Editora Nacional, São Paulo.

1938b. Viagem pelas Provincias de Rio de Janeiro e Minas Gerais 1 : 378 pp., illus.; 2 : 370 pp., illus. (Biblioteca Pedagogica Brasileira, Série 5*, Brasiliana, vols. 126, 126-A). Companhia Editora Nacional, São Paulo.

1939. Viagcm ao Rio Grande do Sul (1820-1821), 404 pp., illus. (Biblioteca Pedagogica Brasileita, Série $5^{\circ}$, Brasiliana, vol. 167). Companhia Editora Nacional, São Paulo.

[1940]. Viagem à Provincia de São Paulo c resumo das viagens ao Brasil, Provincia Cisplatina e Missōes do Paraguai, 375 pp. (Biblioteca Histórico-Brasileira, vol. 2). Livraria Martins, São Paulo.

1941. Viagcm pelo Distrito dos Dianantes e litoral do Brasil, com um "Resumo histórico das revoluçōes do Brasil, da chegada dc D. João VI à América à abdicação de D. Pedro", 452 pp. (Biblioteca Pedagógica Brasileira, Série 5*, Brasiliana, vol. 210). Companhia Editora Nacional, São Paulo.

Sallè, A.

1866. Notice nécrologique sur le Dr. Marco-Aurelio Rojas. Ann. Soc. Ent. France (4) $6: 600-602$. 
Sampaio, A. J. de

1928. Auguste de Saint Hilaire (1779-1853). Bol. Mus. Nac., Rio de Janeiro 4 (4) : 1-31, 1 map.

Saulcy, F. de

1894. Notice nécrologique sur C.-E. Leprieur. Ann. Soc. Ent. France $63: 543-458$.

Stresemann, E.

1951. Die Entwicklung der Ornithologie, von Aristoteles bis zur Urban, I. Gegenwart, 431 pp., If pls., 3 text-figs. F. W. Peterș, Berlin.

1903. Notae biographicae peregrinatorum Indiae occidentalis botanicorum, in his Symbolae Antillanae 3 (1) : 14-158, Lipsiae (= Leipzig)

1908. Vitae itineraeque collectorum botanicorum, notac collaboratorum biographicae, Florae Brasiliae ratio edendi chronologica, systema, index familiarum, pp. 1-CX, in C. F. P. von Martius et al., Flora Brasiliensis, enumeratio plantarum in Brasilia hactenus detectarum quas suis aliorumque botanicorum studiis descriptas et methodo naturali digestas partim icones illustratas 1 (1) : CX + 266 +31 pp.. 59 pls. 
Chapter IX

Entomological collectors in Mexico and Cuba

The Exploration of Mexico

In the works of Macquart, but more especially in those of Bigot. Mexico is frequently cited as the locality of several species described by these authors. In this section we shall accompany some of the naturalists who brought to France the rich collections studied by those dipterists. Unfortunately, only a few isolated details are known about these collectors, and the itineraries are very incomplete.

One of the earliest collectors to arrive in Mexico was Lours PILAte. According to Salle (1852), Pilate travelled through the United States (Alabama, Louisiana and Texas), and explored the State of Yucatán, in Mexico. Returning to France, Pilate decided to visit Mexico again, and came to Yucatán for a second time in 1849. After a prolonged stay in that part of the country, Pilate moved to Mexico City, where he died on 17 March 1852 at the age of 36 years, of a "hypertrophy of the heart".

The relation of Pilate's activities and descriptions of the regions he visited was published by himself in 1846, as follows (Translation by G. C. Steyskal):

"The province of Yucatan, situated in the southeast of the Gulf of Mexico, extends nearly from $17-29^{\circ}$ of latitude. Even in the north, the thermometer does not go below $11^{\circ}$ Réaumur 
(= $13.75^{\circ} \mathrm{C}, 56.75^{\circ} \mathrm{F}$ ) during the coldest part of the winter: the heat there is considerable in the summer. The northern part down to Campeche, is in general arid; it is, so to say, only a vast rock, nearly level and with a wrinckled surface. A single chain of hills about a hundred meters or more in elevation, originates a little south of Campeche, follows the coast northward a few kilometers inland for about 20 leagues and then turns southeastward to the rocky part of the peninsula. One finds there, at various places, especially in the northeast, a kind of subterranean pond called locally senotes: otherwise there is no water during the dry season except in wells, that is, from Norember to the end of May. The vegetation is poor, the thinness of the soil permit nothing to live but shrubs, mostly of the Mimosa family, and rarely are there trees whose highest branches attain more than 10 meters of height. I am not speaking of the cultivated places that are continually irrigated. About a dozen leagues south of Campeche a terrain of another nature starts - from the little river of Champoton, the land is low, flat, humid, and inundated for several months of the year. Finally, in the southern part. rivers abound and the regetation is magnificent. There is never any dryness there and the country is very unhealthy. I lived in the capital (Mérida, in the northeast) for 5 years and made only short trips to other localities; there was hardly anything in the north that I could secure besides insects. It is easy to imagine that I would find little, and generally only small, insects, in a dry and sterile land. I might add that except for a dozen Coleoptera. everything is rare: in 4 or 5 hours of searching 1 often found only a few specimens. However, in May and June there are more. In the rainy season diurnal Lepidoptera are abundant. but not of many kinds. Except for mosquitoes and the housefly. Diptera are very rare, and I would say the same about all other insects. I needed plenty of perseverance, a very determined attitude, and the aid of a domestic for 10 years. with nothing else to do but collect, to gather together here $\$ 000$ Coleoptera comprising almost 720 species, of which 500 about are new."

The Belgians also collected in Mexico: special mention must be made of Ghiesbreght. Linden, and Funck.

August B. GHIEsBregut (the Ghisbretch or Ghiesbrecht of Macquart) (1810-1893) was the zoologist of a Belgian commission charged by the government to undertake a scientific exploration of Mexico and other tropical countries. The other two members were Jean Jules Linden (1817-1895), a botanist, and Nicholas Funck (1819-1896), the artist of the expedition. 
Their first voyage was to Brazil, where they arrived in December 1835; they visited the provinces of Rio de Janeiro. Espirito Santo, Minas Gerais, and São Paulo (see voyage of Saint-Hilaire for an idea of itineraries). In March 1837 they returned to Belgium with the zoological and botanical collections obtained. Their second voyage was made to Havana, Cuba, where they arrived in December 1837. The Belgians spent 3 months on the island, exploring its northern and western districts, and left in March 1838 for Mexico. There they visited the plateau of Anahuac (?), the volcanoes Popocatepetl (NE-14, 19-99b) and Iztacchihuatl (Ixtacihuatl. NE-14, 19-99b), the Cofre de Perote (or Nauhcampatepetl, NE-14,19-97a), the peak of Orizaba (or Ciflaltepet1, NE-14, 19-97a), and all the eastern slopes of the Cordillera. From Veracruz they sailed to Campeche (NE-15. 20-91d), crossed Yucatán, and then went by sea to visit the states of Tabasco and Chiapas, entering also northern Guatemala. Linden then went to Havana and the United States, and the commission returned in February 1841 to Belgium.

It seems that from 1840 on. Ghiesbreght travelled alone, living in Tabasco, and then in Chiapas; although repeatedly visiting Europe, Ghiesbreght spent many years in Mexico. Nothing else is known to me of his life and travels.

Linden, however, undertook a third royage, with Louis Joseph Schlim, this time to South America. Landing at La Guaira (NC-19,11-67d), Venezuela in December 1841, he explored the coast from Caracas (NC-19,11-67d), to Cumaná (NC-20, 10 , -64a), going then to the shore of the Lake of Maracaibo (NC-18, 10-72d; NC-19, 9-71a), Mérida (NC-19, 9-71c), and San Cristóbal (NC-19, 9-71b). Entering Colombia, they proceeded through Cuicuta (NB-18,8-73d), in the Department of Norte de Santander, the cities of Bucaramanga (NB-18, 7-73a), Socorro (NB-18, 6-73a) and Barbosa (NB-18, 6-74d), in the Department of Santander, crossed the western part of the Department of Boyacá, entering the Department of Cundinamarca, and finally reached Bogotá (NB-18, 5-74c).

From Bogotá Linden and Schlim went north, to the Department of Tolima, visiting Honda (NB-18, 5-75b). Mariquita (NB-18, 5-75b). Tolima (NB-18, 4-75a) and Ibaqüé (NB-18, 4-75a). Proceeding through Armenia (NB-18, 5-76d), Pareira (NB-18, 5-76d) and Puerto Caldas (NB-18, 5-76d), all in the Department of Caldas, the naturalists reached Cartago (NB-18, $5-76 \mathrm{~d}$ ) in the Department of Valle, and from there went to visit the Pacific coast. 
Returning to Cartago they retraced their steps to Bogotá (NB-18, 5-74c), and visited the regions of Tunja (NB-18. 6-73c) and Tundama (?) (? Tunamas, NB-18, 5-73b).

Leaving Bogotá, the naturalists returned by the same route to Mérida (NC-19,9-71c), in Venezuela, and proceeded through Trujillo (NC-19, 9-70a), and Barinas (NC-19, 9-70 c), to visit the "llanos" of the Orinoco, and through Carabobo reached $\mathrm{Ca}$ racas on 17 August 1843.

In the following months they explored Puerto Cabello (NC-19. 10-68a) on the coast of Venezuela, and sailed again to Colombia, arriving in Rio Hacha (NC-18, 12-73d), in the Department of Magdalena, whence they went overland to the Sierra Nevada de Santa Marta (NC-18,11-74b). Returning then to Rio Hacha, they sailed in March 1844 to Jamaica.

In Jamaica they spent some weeks collecting in the Blue Mountains (NE-18, 18-77b), leaving then for Cuba. In a period of six months they visited the eastern part of the island, the Sierra Maestra, the plains of Saltadero (?) and Yateras (NE-18. NF-18, 20-75d), the mountains Libano and Toro (?), the forests of Los Hondones and Sagua (?), the Sierra del Cristal (NF-18. 21-75c), the Sierras of El Cobre (NF-18, 20-76b). "Nimanima" (?), and the Rio Cauto (NF-18, 21-76c) basin. In October 1844, they left Cuba for North America, and thence to Europe (Pennell, 1945: 45: Urban, 1903).

Although only the name of Ghiesbreght is cited by Macquart, it is possible that in the same collections insects collected by Linden. Funck and Schlim were also included. According to the Paris Museum book of accessions (Vol. 3, p. 83) (Cataloguse des animaux sans vertébres). Ghiesbreght sold insects to the Museum in 1842, for 30 francs per a hundred specimens.

On the other hand, most of the insects collected in Mexico were acquired in Europe through professional collectors, who explored Mexico for many years, visiting almost every State of the country. Foremost among these are Salle and Boucard, about whom we have very litile information.

Auguste SAllé died in Paris on 5 May 1896, in his 76th year. He travelled much in the southern United States, Mexico, West Indies, Central America, and Venezuela, making collections in all branches of entomology. On his return to Europe he established himself as a natural history agent in Paris. He several times took temporary charge of important collections - the rich collection of Baron de Chaudoir was kept in his house during the siege of Paris in 1875. His Central American collections were purchased by Godman and Salvin for the Biologia 


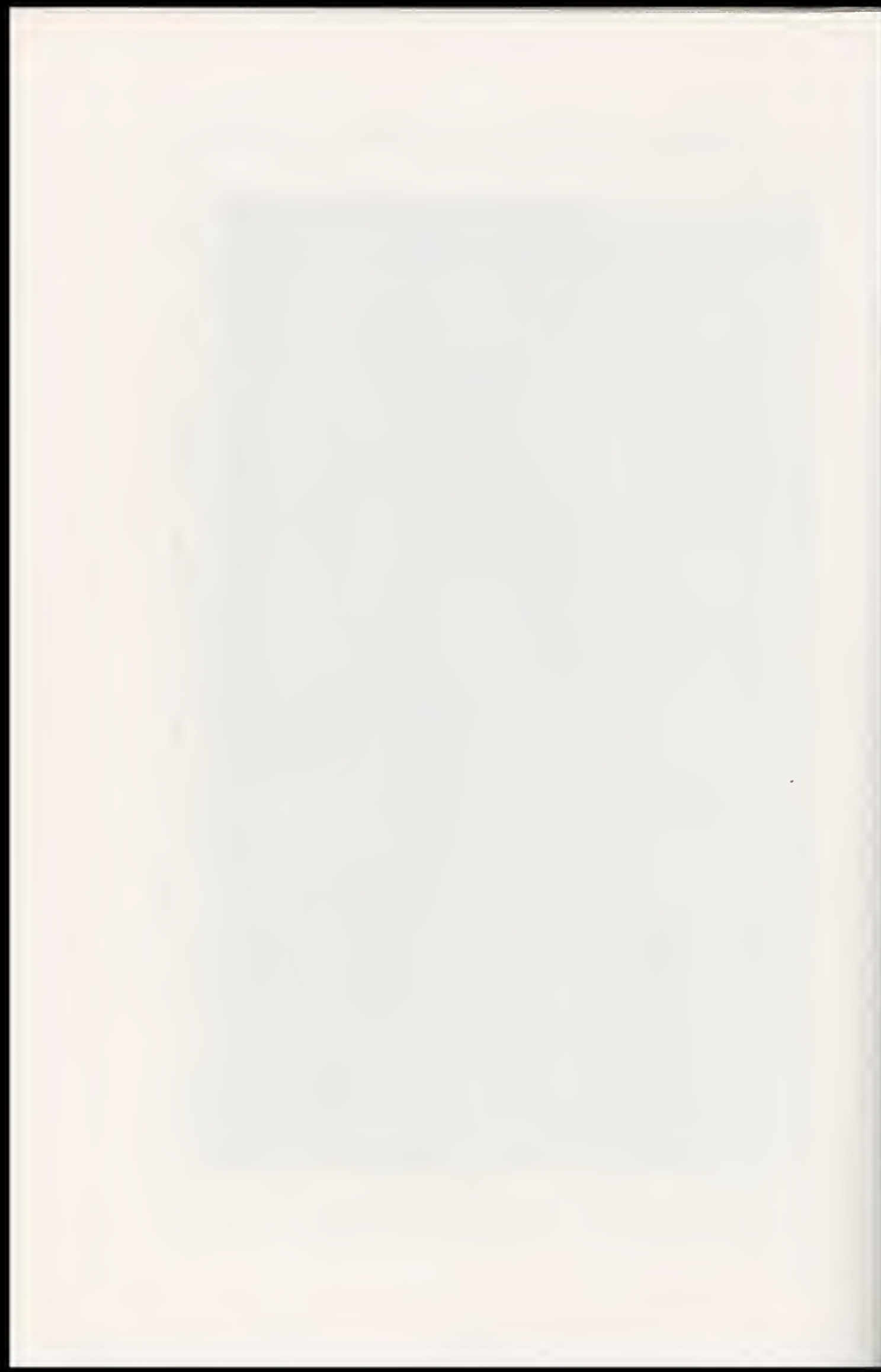


Centrali Americana. Salle was elected a fellow of the French Entomological Society in 1857 and of the Entomological Society of London in 1875 (Anon., 1896).

About Adolphe Boucard I have no information. He seems to have been a general collector, but more especially dedicated to birds and insects. He wrote an account of his extensive travels through the United States, Mexico, Central America, Colombia, Chile, and other countries (1894), which unfortunately I have not been able to consult. In 1867 he published a catalogue of the natural history collection that he had gathered in Mexico. In 1878 another catalogue of the collections obtained in Guatemala, which were exibited at the "Exposition Universelle de Paris", and perhaps about the same time a list of Coleoptera offered for sale. According to Carriker (1910) he collected in Costa Rica in 1877. spending there several months, which he used in visiting Puntatarenas (NC-16, 10-85d). San José (NC-16, 10-84c; NC-17. 10-84c). Cartago (NC-17, 10-84d). Orosi (NC-17, 10-84d), Navarro (NC-17, 10-84d). Volcán de Irazú (NC-17, 10-84d), Juan Viñas (NC-17, 10-84d) and San Carlos River (NC-16, 11-84c), probably at the Comandancia de San Carlos (op. cit., p. 362). Boucard printed a list of the birds collected during this trip (1878).

Two other naturalists of this period are the brothers Dugès. Alfred Auguste Delsescautz Dugés and his brother Eugène were born in Montpéllier, France, around 1826. Their father Antoine Louis Delsescautz was a medical doctor, professor of the University of Paris, and naturalist. Upon their father's death. the two brothers moved to Paris to study medicine. Alfred left for Mexico arriving in May 1853. As soon as his medical title was recognized in Mexico City. he moved to Guanajuato (NF-14. 21-101a). where he remained practicing medicine and teaching natural history. His brother Eugène came to Mexico only in 1865. becoming also established in Guanajuato as a medical doctor. Eugène was an entomologist, and sent collections to Paris. Later he founded a museum of natural history in Morelia, and died in that city on 13 January 1895 (Anon.. 1895). Alfred also used to collect in the neighborhoods of Guanajuato, especially on Sundays, accompanied by his students. He died at 84 years of age on 7 January 1910 (Martin del Campo, 1937).

\section{The exploration of Cuba: Sagra, Poey, Gundlach}

RAmon dE lA SAGRA was born in Coruña, Galicia, Spain, in 1798. Placed in charge of the directorship of the botanical gardens of Havana. Cuba, by his government, he left for the 
island in 1824. He soon became widely known, not only because of his difficult personality ("personalidad que ha sido objecto de encontradas opiniones por su menosprecio hacia los valores cubanos", as says Aguayo, 1950:7). but also for having reformed the Botanical Gardens, teached botany, studied the useful plants of Cuba, applied botanical knowledge to medicine and agriculture, and published the "Anales de Ciencias, Agricultura, Comercio y Artes". Very early in his life in Cuba, he had the idea of publishing a great work about the island encompassing all branches of knowledge. With this in mind. he contracted in every part of Cuba several specialized collectors who sent him the natural productions of the three kingdoms. In 1835 Sagra left Cuba, taking all his materials to Paris, where, with the collaboration of several specialists. he started to write his work. Sagra wrote the introduction to the work, and the parts on the climate and agriculture: Gervais was in charge of the mammals: d'Orbigny of the birds, mollusks, and Foraminifera; Cocteau and Bibron studied the reptiles and amphibians; Guichenot described the fishes: Guerin-Meneville published on the crustaceans and insects: Bigot described the Diptera, and Lucas described the Arachnida. The work took 20 years to complete and was published in fascicles. from 1842 to 1856 . It resulted in 13 volumes in folio. with many hand-coloured plates. Sagra remained afterwards in Europe, became General-Consul of Uruguay, and died in June 1871 in Cortaillod. Neuchãtel. Switzerland (Aguayo. 1950: Urban. 1903).

Sagra did not include in his work materials collected by Cuban naturalists, due to his attitude towards the natives. One of the important collections which he thus orerlooked was that assembled by Poey.

Felipe Poer y Alor was born in Havana, Cuba, in 26 May 1793, and died on 28 January 1891. Before studying natural sciences he studied law in Havana. Going to France, he studied under Cuvier, who placed under his care the collection of Cuban fishes of the museum. In France he was elected fellow of the Entomological Society. His first works dealt with entomology. especially with Lepidoptera, on which he published two parts of his projected "Centuria de Lepidópteros de Cuba" (1847).

In the middle of the 19th century he started to edit his "Memorias sobre la Historia Natural de la lsla de Cuba". a work. in two volumes. published in fascicles from 1851 to 1861 . Later he also edited, in two volumes published in fascicles. his "Repertorio Fisico Natural de la Isla de Cuba" (1865-1866), with 
the cooperation of Gundlach. Arango, Presas, Jimenez, Aguilera and other Cuban naturalists.

He also published many papers on mollusks and fishes. Of the latter, he described over a hundred species from Cuba. On 24 October 1842 he was appointed professor of zoology and comparative anatomy; in 1863 was put in charge of the chairs of zoology, botany, mineralogy and geology, and after the reform of 1871, of the chairs of zoology and mineralogy only. From 1880 to 1881 he taught vertebrate zoogeography, and invertebrate zoology. In 1873 he was appointed dean of the "Facultad de Filosofia, Ciencias y Letras".

He sent several Cuban collections, gathered by him, Gundlach, and other naturalists, to the Museum of Paris, where they were studied by Bigot.

Juan Cristóbal Gundlach, one of the greatest collaborators of Poey, was born on 17 July 1810, in Marburg, Electorate of Hesse-Nassau, Germany. There he remained until he was 28 years old. Although he lost his father at an early age, his mother did not neglect his education, and he graduated from the University of Marburg, as "Magister Artium Liberalium" in 1837. and "Doctor Philosophiae" in 1838, specializing in zoology. Afterwards he moved to Frankfurt am Main, to further pursue his studies, and there conceived the idea of travelling to a tropical country.

Leaving Hamburg on 3 November 1838, he landed in Havana (NF-17, 23-82), Cuba, on 5 January 1839. He was accompanied by the malacologist and medical doctor Luiz Pfeiffer, and by the botanist Eduard Otto. The three naturalistas established themselves on a coffee estate, "San Antonio, Fundador de Canimar", $9 \mathrm{~km}$ from the city of Matanzas (NF-17, 23-82b). as guests of Carlos Booth y Tinto, a wealthy Cuban gentleman.

Pfeiffer remained in Cuba only two months, returning to his country in March; Otto went on to Caracas, after first visiting the United States. Gundlach remained exploring the coffee plantation, making frequent excursions to Punta de Maza (?). in the Bay of Matanzas (NF-17, 23-82b). In 1842 he moved to the "finca" San Juan, near the city of Cárdenas (NF-17, 23-81a). In 1846 he spent several weeks in Cayo Piedras (NF-17, 22-81 c).

In the second half of 1849 he met Father Ramón de La Paz Morejón, an enthusiast of natural history, and from him received a letter of recommendation to some relatives who lived in several places near Ciênaga de Zapata (NF-17, 22-81a). In September 
Gundlach visited "Hato Zarabanda", situated in the central part of the Cuban peneplain next to the Ciennaga de Zapata, where he gathered in a short time a considerable amount of natural history specimens.

In the summer of 1850 he visited Caibarien (NF-17, 23-79c). In 1852 he decided to visit the city of Havana (NF-17, 23-82a). to meet personally Felipe Poey, with whom he had maintained a scientific correspondence since 1841. In the next year, commissioned by Nicolás J. Gutiérrez, president of the Academy of Sciences, and by Poey, he moved to the Isla de Pinos (NF-17, 22-83d), exploring the Sierra Columpo (NF-17, 22-83d). Sierra de Caballos (NF-17, 22-83d). Sierra de las Casas (NF-17, 22-83d), especially for mollusks. He collected more than 60 species of birds, dozens of reptiles and a great number of insects.

In 1855, invited by the botanist Francisco Adolfo Sauvalle. he visited the "finca" Las Playitas, near Bahia Honda (NF-17, 23-83a), in the Partido of Las Pozas. Gundlach passed through Pan de Guajaibón (?), Arroyo Canillas (?), Rancho Lucas. arriving in Hato Rangel (?), where the botanist José Blain was waiting for him. Blain lived in a rustic house in his "finca" El Retiro, near Santa Cruz de los Pinos (NF-17, 23-83c), at the foot of Monte Rangel, on the margins of the $R$. Taco-Taco (NF-17, 23-83c).

Gundlach returned to Havana and published in the Memorias of Poey an extensive report on his fruitful trip to Las Playitas. (NF-17, 22-83a) and then in the middle of 1856 started on a more important excursion, to the oriental regions of Cuba. Starting his trip in Cienfuegos (NF-17, 22-80a), and following the southern coast, he reached Trinidad (NF-17, 22-80d) on 12 September, presenting himself to Justo Germán Cantero, "gentil hombre de cámara de S. M. y alférez real", who received Gundlach as guest in his sugar-estate "Magua", whence Gundlach went to visit the sugar-estates of Buenavista and Güinia de Soto: then. going to Quemado (NF-17, 22-80d), he visited the farms San Juan de Latrán and Hato Naranjo. He afterwards explored the "lomas de Banao" (NF-17, 22-SOd), where he stayed for 8 day's, returning to Trinidad to ascend the mountain El Vigia.

From Trinidad he went to Manzanillo (NF-18, 20-77a). arriving at the end of February 1\$57, and from there to Santa Cruz (?) and Punta del Inglés (NF-18, 20-7Sd), returning in April to Manzanillo. Travelling on horseback, he next visited Bayamo. (NF-18, 20-77b). From there he went on a side trip to Guisa, a small village, and in October went to Cayamas, on 
the Rio Cauto (NF-18, 21-76c), which he travelled down by boat to its mouth, and by sea went again to Manzanillo, after visiting Cabo Cruz once more. After a month he embarked to Santiago de Cuba (NE-18, 20-76b), visited the coffee plantation Santa Maria, near Enramada (now San Luis; NF-18, 20-76b). and Gran Piedra (NE-18, NF-18, 20-76d) in the Sierra Maestra. In June 1858, he reached Caimanera (NE-18, NF-18. 20-75d). where he stayed for 7 weeks with Teodoro Brooks and Enrique Lescaille, employees of the railroads of Guantánamo. In September of the same year Lescaille resigned from the railroad administration to take better care of his coffee plantation Ermitano, in Yateras (NE-18, NE-18, 20-75b), and took Gundlach "as guest. The naturalist visited several coffee estates and "Fincas" in the vicinity, and went on to Monte Libano, and Monte Toro (now Monte Rus), returning to Guantánamo (NF-18, 20-75a) by way of Santa Fe (?), and then proceeding to Santiago de Cuba (NE-18, NF-18, 20-76b), with a stop in Caimanera (NE-18, NF-18, 20-75d). In May 1859 he reached Baracoa (NF-18, 20-74a), visiting
Punta de Mata (NF-18, 20-74a) and the El Yunque coffeeplantation. By sea he went to Gibara (NE-18, 21-76a), collecting in the neghborhood, and continued through Nuevitas (NF-18, $22-77 \mathrm{c})$, arriving in Havana $(\mathrm{NF}-17,23-82 \mathrm{a})$ on 15 August 1859 after an absence of more than 3 years.

In 1867. by decision of the Cuban government, Gundlach transported all his collections to Paris, where they were exhibited it the "Exposition Universelle".

At the request of Leopold Krug, the German vice-consul in Mayagüéz, Gundlach visited Puerto Rico in 1873, remaining there collecting for approximately 6 months.

In 1875 he undertook a second voyage to Puerto Rico, where he spent one year. The data obtained on his two voyages were published as "Apuntes para la fauna Puerto-riqueña", in the Anales de la Sociedad Española de Historia Natural, from 1878 to 1893.

In the years 1884 and 1888 Gundlach spent most of his time in the oriental region of Cuba, in the company of his old friends. In 1890 he decided to sell his collection to the Instituto de Historia Natural de Havana, and on 7 December 1892, the sale was made.

Attacked by bronchopneumonia, he died on 15 March 1896 at 89 years of age (Aguayo, 1950; Castellano Rodiles, 1960;
Mestre, 1915). 


\section{References}

Aguayo, C. G.

1950. Bosquejo historico de la zoologia cubana. Bol. Hist. Nat. Soc. "Felipe Poey", Havana 1 (1) : 3-31.

Anonymous

1895. [Eugène Dugès, biographical note]. Zool. Anz. $15: 260$.

1896. [Auguste Sallé, biographical note]. Trans. Ent. Soc. London (Proc.). 1596 : xcin-xciv.

Boucard, $A$.

1867. Catalogue des collections d'histoirc naturelle rẻcoltécs au Mexiquc par M. A. Boucard, 16 pp. Typ. Oberthur et fils, Rennes.

187?. Liste de coléoptères en wente chez A. Boucard, $27+1$ pp. Typ. Oberthur et fils, Rennes.

1878a. Notice sur les objets cxposés par la République de Guatemala et par Adolphe Bouseard a l'Exposition Universelle de Paris, $32 \mathrm{pp}$.

1878b. On birds collected in Costa Rica. Proc. Zool. Soc. London 1575 : 37 .

159t. Travels of a naturalist. A record of adventures, discoverics, history and customs of Amcricans and Indians, habits and descriptions of animals, chicfly made in North America. Callfornia. Mexico, Central America, Columbia, Chili, etc., during the last forty two years. vil $+11+204$ pp. Pardy \& Son. Printers. Bourncmouth, London. (Not seen, Library of Congress card $\mathrm{E} 27 . \mathrm{B} 75)$

Carriker, M. A.. Jr.

1910. An annotated list of the birds of Costa Rica including Cocos Islands. Ann. Carnegie Mus. 6 : 314-970, 1 map.

Castellano Rodiles, I.

1960. Juan Cristóbal Gundlach. Pusl. Soc. Cubana Hist. Na:. "Felipe $P_{\text {ocy }}{ }^{\circ} l: 111$, illus.

Martin del Campo, R.

1937. Alfredo Augus:o Delsescautz Dugis. Ensayoo biografico. An. Ins: Biol. México $S: 43 i-455,3$ liggs. 
Mestre, A.

1915. Homenaje a Poey. - Datos biograficos. Mem. Soc. Cubana Hist. Nat. $15: 3-8$, portrait.

Pennell, F. W.

1945. Historical sketch, pp. 35-48, in F. Verdoorn, ed., Plants and plant sciences in Latin America. xxxvi + 381 pp. Chronica Botanica Co., Waltham, Massachusetts.

Pilate, L.

1846. [Letter about his travels in Yucatán]. Bull. Soc. Ent. France (2) 4 : XCVI-XCVIr.

Sallè, $A$.

1852. L. Pilate, biographical note. Ann. Soc. Ent. France (2) 10 (Buil.) : L.

Urban, I.

1903. Notae biographicae peregrinatorum Indiae occidentalis botanicorum, in his Symbolae Antillanac 3 (1) : 14-158. Lipsiae (= Leipzig). 


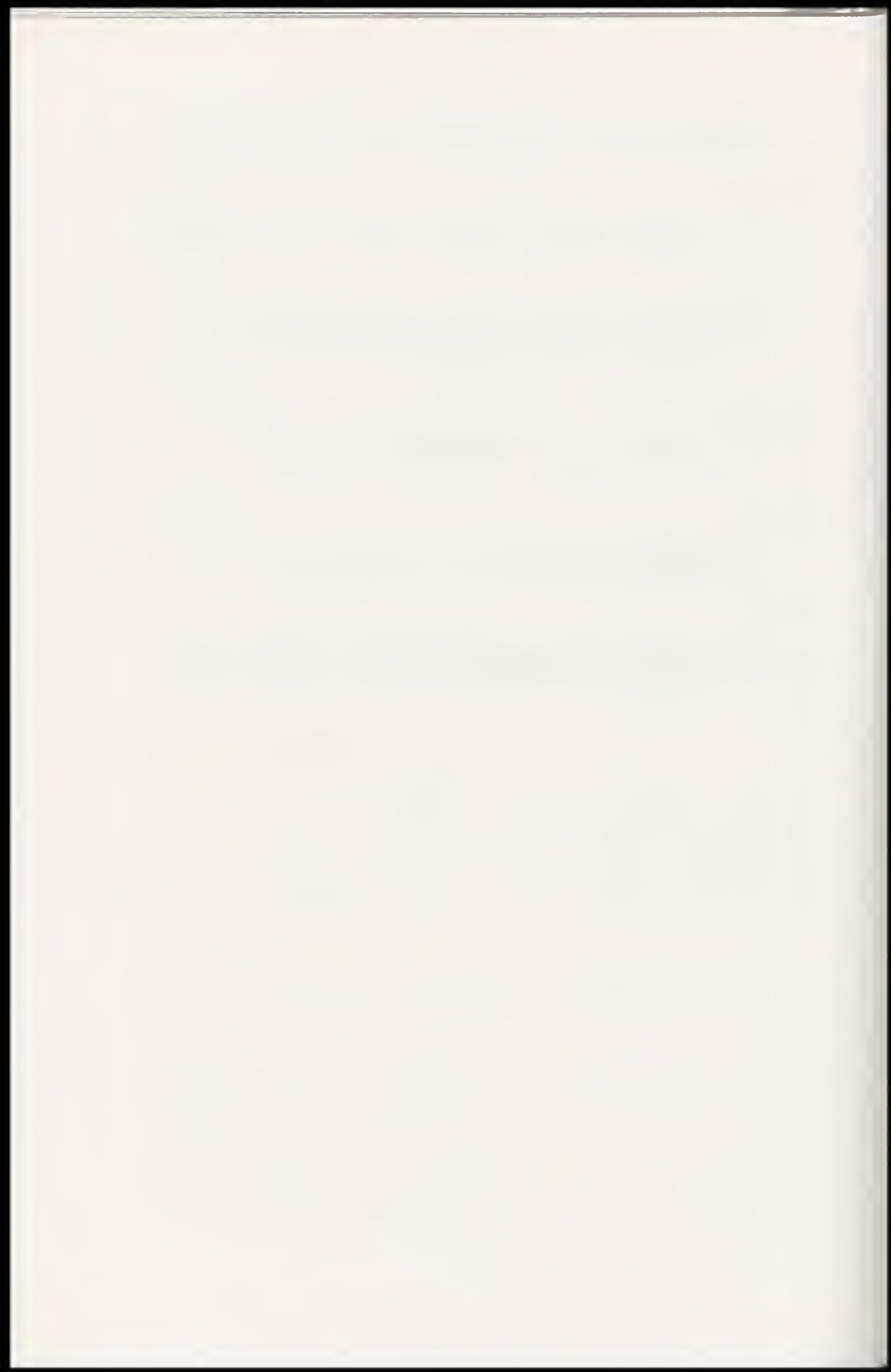




\section{Chapter $X$ \\ The French Dipterists}

\section{Guérin-Méneville}

Félix Édouard Guérin-Méneville was born in Toulon, France, on 12 October 1799. There he made his first studies. His interest in natural sciences began early in life, due to the influence of Dumont d'Urville and Lefebure de Cerisy. Leaving his native town, he went to Amiens, where he remained for a short period, and finally moved to Paris, where he lived permanently. He was one of the most prolific writers in entomology, and studied the insects collected by Lesson and Duperrey during the cruise of 'La Coquille' (1831, 1838), and several other collections brought to the Paris Museum by other expeditions. He also published an "Iconographie du Règne Animal" (1829-1844). He died in Paris on 26 January 1874 (Anon., 1874).

\section{Olivier}

Guillaume Antoine Olivier was born at Arcs, near Fréjus, France, in 19 January 1756 , and died at Lyons in 11 August 1814. He studied medicine at Montpellier and meanwhile became interested in natural history, chiefly because of his acquaintance with the naturalist Pierre Marie Auguste Broussonnet (1761- 
1807). Upon completing his medical course he returned to his native place. Finding medicine unattractive and unprofitable he found employment, through the aid of Broussonnet, in making a statistical and economic study of the natural products in the vicinity of Paris; the work was done in such a thorough and commendable manner that he was engaged by Gigot d'Orcy, a wealthy amateur entomologist, to collect insects in Holland England, and other countries. This opportunity enabled him to procure material for his "Encyclopédie Méthodique", and his great work on Coleoptera.

One of the parties which held temporary authority during the French Revolution decided that a mission should be sent to establish commercial relations with Persia, and Olivier and Bruguière (a merchant of Nimes. Gard, France) vere commissioned to accompany it in the capacity of naturalists. Olivier was engaged on this expedition for six years, during which he suffered much inconvenience in consequence of the fall from power of the minister, Roland, the projector of the mission, his successors considering of no importance to trade with Persia. He returned to France in December 1798, bringing with him large natural history collections made in European and Asiatic Turkey. Asia Minor, Persia, Egypt, and various eastern Mediterranean islands. Having enough money to live on he set about describing and publishing the insects and other animals thus collected. He was appointed Professor of Zoology of the Veterinary School of Alfort and became a member of the Institut de France in 26 January 1800 . He became nationally known as a great entomologist and was visited by most of the contemporaries of the time. being especially intimate with Fabricius. He was a patron. protector, and provider of Latreille during the revolutionary period from 1810 to 1814 .

In the latter part of his life, his health, which had been very robust. failed, and he travelled through different parts of Europe to restore it; but he was found dead in his bed at Lyons on I October 1814. His disease proved to have been an aneurism of the aorta, the existence of which had not been suspected by his physicians (Essig, 1931: 719-721).

\section{Robineau-Desvoidy}

“Jean Baptiste Robineau-Destoidy was born January 1, 1799 in St. Sauveur en Puisaye, a little town southwest of Auxerre (Department of the Yonne). He studied in Auxerre and in 
Paris, obtained his doctorate in 1822, and since then spent his life in his native place dividing his time between his medical duties and his favorite pursuits. The district in which he lived was unattractive, marshy and unhealthy, with poor and sickly inhabitants. Having inherited a sufficient competence ("assez comfortable independence") he never attempted to increase it. He built a villa (which he called "Hermitage") in a cold and damp valley near St. Sauveur and there he lived in isolation. With great disinterestedness he performed the daily taks of visiting his numerous patients ("il ne savait pas ce que c'étaient des honoraires") and in this respect his biographer renders him an ample justice ("une éclatante justice"). His health finally gave way under the deleterious influence of the climate, and after prolonged sufferings, a short time before his death he was removed to a private hospital in Paris. where he died in 1857 in his 59th year. The love and admiration he inspired to the small circle of his friends found an eloquent expression in the memorial speech pronounced by Dr. Duche during the meeting of the French Scientific Association in Auxerre in 1858. This speech is prefixed to his posthumous work: Diptères des Environs de Paris. The publication of this posthumous work was another act of friendly devotion to his memory. Mr. Monceaux, secretary of a scientific society in Auxerre, an entomologist, but by no means a Dipterist, undertook the onerous and thankless task of publishing the manuscript left by Robineau. It cost him several years not only of editorial labor, but also of negociations to overcome the opposition against this publication, and to obtain the means for carrying it out.

Robineau's publications embrace not only zoology, but also geology, paleontology, local history, archeology. statistics, etc.. principally with reference to his native district. Besides, he seems to have been a good Latin and Greek scholar, and to have possessed an admirable power of expression, both in speech, and in writing $(\ldots)$.

His large work was printed in 1830 , but he must have been occupied with it for many years. because (...) he gives 1826 as the date of the presentation of the manuscript to the Academy of Sciences. Between 1830 and his death he was incessantly at work on preparing his Diptères des Environs de Paris (...).

The impossible task he had undertaken, to base the classification of the imagos on the mode of life of the larvae, was doomed to failure. His rupture with Macquart became a public one after the publication of the 2 nd volume of Macquart's Histoire Naturelle des Diptères (1835). Macquart in his work absolutely 
ignores Robineau: his name appears only in the list of abbreviations and is also connected with some of the new species published by Robineau (...). Robineau criticized Macquart, and called his volume a mere compilation (...). Robineau seems finally to have become a bette noire among the official scientists of Paris" (Osten Sacken, 1893: 383).

In his "Essai sur les Diptères" (1830) Robineau-Desvoidy described many exotic Diptera, based on the collections gathered by Poey in Cuba, Palisot de Beauvois in "Saint-Domingue". Hodgard in Haiti, Leschenault de la Tour and Doumerc in the Guianas, Humboldt in Peru and the largest of all, the one gathered by Saint-Hilaire and Delalande in Brazil. Robineau-Desvoidy mentions in regard to the latter "Rio Grande" (voyage of Saint Hilaire to the eastern part of Rio Grande do Sul). "Missions" (Rio Grande do Sul. western part). "Guaratuba" (a city in the coast of the State of Paraná). "capitainerie des mines" (Saint Hilaire's first voyage to Minas Gerais), and "Centre du Brésil" (Saint Hilaire's second voyage to Minas Gerais and voyage to Goiás). as the locality of most of his new species of Diptera. Very probably, due to his incompatibility with Macquart, many of the latter's species are synonyms of Robineau-Desvoidy's, since both studied the same collections in Paris.

\section{Macquart}

Pierre Justin Marie Macquart was born in Hazebrouck, 45 $\mathrm{km}$ west of Lille (Nord). France, in 1776. In his parental home there was a garden where Macquart first became interested in natural sciences. His older brother, a fellow of the "Societé des Sciences de Lille". was an ornithologist, and assembled a sizable collection which. after his death, served as the starting point for the Lille Museum. A second brother was interested in botany, and built a botanical garden with over 3.000 species. Macquart also became interested in natural history. choosing entomology as his field. His first paper, published by the Lille Scientific Society, dealt with Psyllids.

At the age of 21 he had to leave his native place to join the Army of the Rhine. He went to Mannheim. entering the Corps of Engineers. During his leaves he was able to explore the banks of the Rhine, so rich in natural productions. He served the commander of the Army of the Rhine. General Armand Samuel, Marquis of Marescot, in the quality of secretary and draftsman. With the Army he visited Schwetzingen. Heidelberg. 


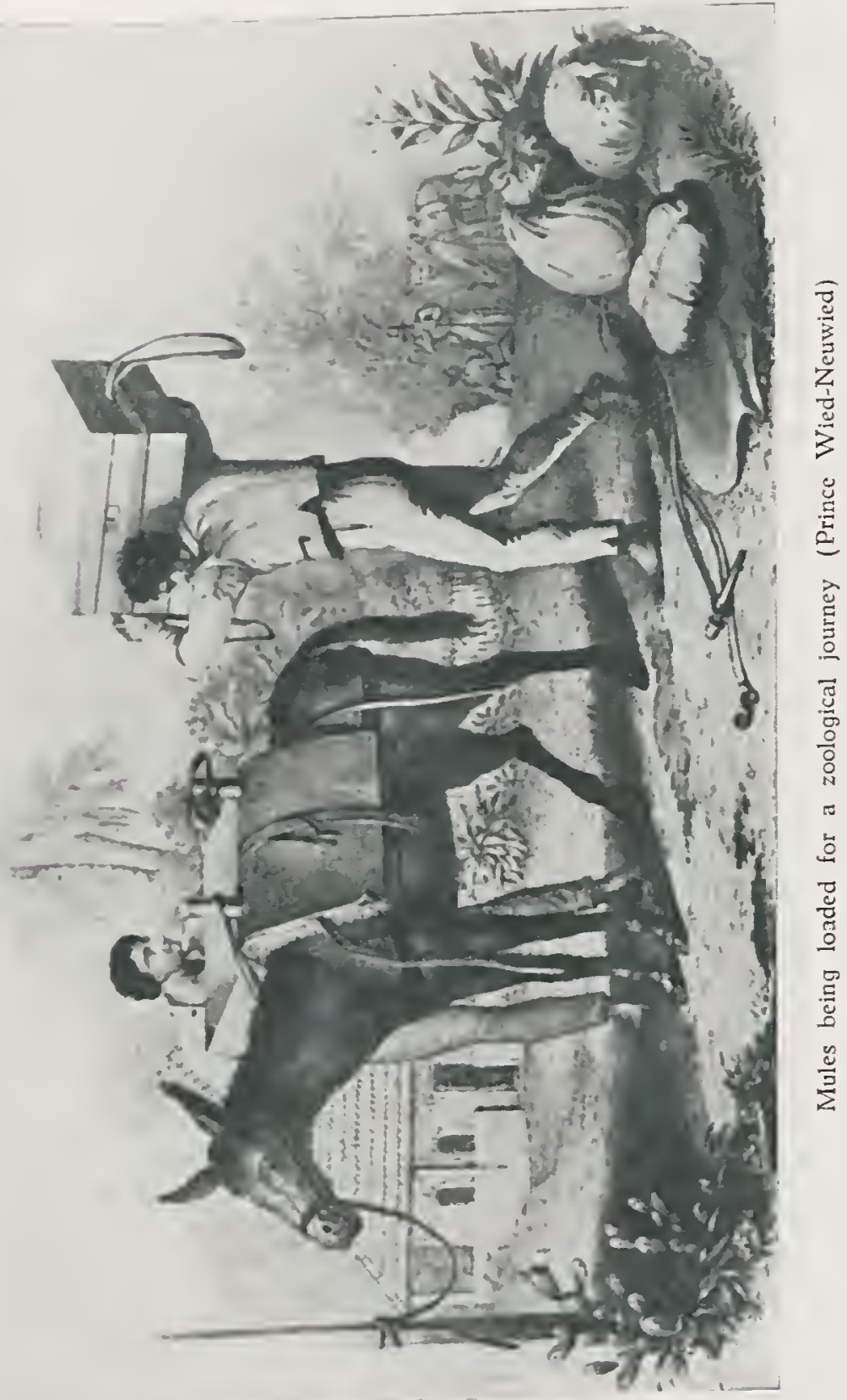

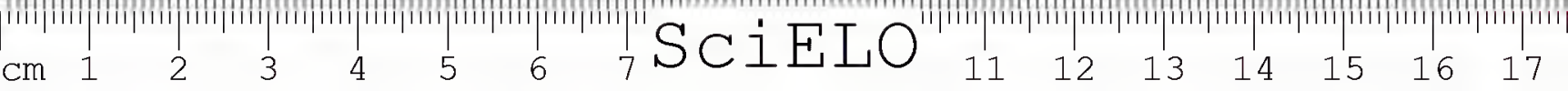




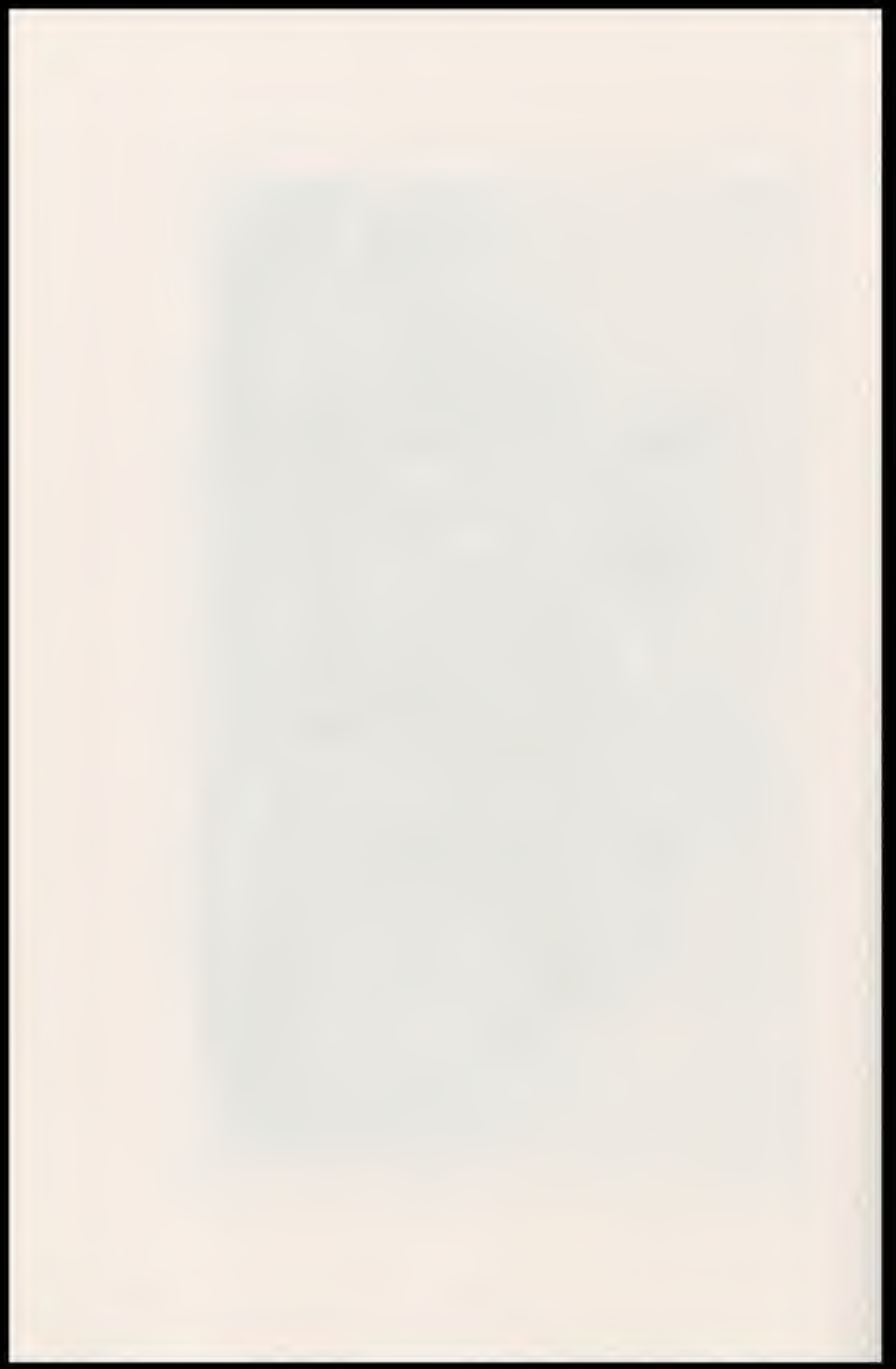


and Mainz, passing to Switzerland, to Arau and nearby places. Afterwards the general staff moved on to Zurich. returning to Arau and Basel. While Macquart stayed at Basel he received the sad news of his mother's death. He returned to Lille, after an absence of 18 months (1797-1798).

From the military campaign through Germany and Switzerland he brought home German books, a herbarium, insects and birds.

Once established again in Lille he dedicated himself entirely to natural history, and during the winters studied in the public library of Lille. On 27 nivôse. "an" XI (1802) he was elected fellow of the Societé des Sciences, de L'Agriculture et des Arts de Lille.

Macquart also travelled frequently to several regions of France, especially to Paris, where he followed the entomological lectures of Latreille. The great entomologist identified the collections gathered by Macquart and encouraged him in his career.

After a trip to Holland, Macquart's "wandering life became settled by a happy marriage, followed by a happy and numerous paternity" (Macquart, 1850a).

Following his marriage, he moved from Hazebrouck to Lestrem, living in a house made of two towers, remains of a castle from the XIV century, in the middle of a beautiful village, near the banks of the Lawe, a tributary of the Lys. Eventually he became the mayor of Lestrem, and a member of the "Conseil général du Pas de Calais".

He started then his studies of Diptera, made easier by Meigen's publications. With the help of the works of the great Master he started the study of the French Diptera, which resulted in his "Diptères du nord de la France" (1828-1833). This work opened to him the important collections and libraries of the time: Blainville, Geoffroy Saint-Hilaire, Férussac, Lepelletier de SaintFargeau, Audinet Serville, Audouin, Carcel, Al. Lefebvre, Brullé, Castelnau, Winthem, etc.

Soon after the publication of this work. Latreille thought of editing a special work on insects, in collaboration with several entomologists, and invited Macquart to take care of the Diptera. This project. whose execution was delayed by the death of the editor, was afterwards started again, under the editorship of $N$. E. Roret, and the name changed to "Collection des Suites à Buffon, formant avec les oeuvres de cet auteur un cours complet d"histoire naturelle" ( 82 volumes, 11 atlases). Macquart worked very hard, preparing the "Histoire Naturelle des Insectes Diptè- 
res", studying the collections in the Paris Museum and several private collections. Once the two volumes were published (18341835), he received a number of collections of exotic flies and established relations with all the leading entomologists of his time.

In the meantime, he travelled throughout France and Belgium. In 1839 he visited Meigen in Stolberg, where he saw the collections, 3,000 drawings of flies done by the great dipterist, and Meigen's library, which contained exclusively his own writings. As Meigen was in straitened conditions. Macquart offered to buy his collections. After obtaining permission from the authorities of the Paris Museum, Macquart acquired the famous and valuable collection.

Returning to the Museum of Paris, and having at his disposal the great collections brought home by French expeditions and collecting naturalists in almost every corner of the globe, Macquart undertook the description of the new species in the Museum, since these had not been examined by Wiedemann while working on exotic flies, and only a few had been dealt with before in the works of Guerin-Meneville. Olivier. RobineauDesvoidy, and Macquart's own "Histoire Naturelle". In this great series, published from 1838 to 1855 , in two tomes and five supplements, he described some 1.800 species. In the first volume of his "Diptères nouveaux ou peu connus" $(1835: 15)$ he gives a list of the collections studied:

"In France, the exotic Diptera brought back during the last few years, and not seen by Wiedemann, are due in large part to the searching of our travellers. whose love of natural sciences has impelled them to gather in these specimens for their fatherland:

Gay and Fontaine in Chile and Peru

Sylveira, Gaudichaud-Beaupre., Wauthier (=Vauthier) in Brazil

Lepricur, Leschenault de la Tour, Doumerc, and Mme. Rivoire in Guiana.

Lebas in Colombia

Richard, Lacordaire, and Banon in Cayenne

Plée in the Antilles

De La Sagra, Poey in Cuba

Hogard in Santo Domingo

Beaupertuis in Guadeloupe." 
Macquart also studied the private collections of Castelnau, and those of Guérin-Méneville, and Olivier, which included the flies gathered by the several French Expeditions of the ships L'Ouranie, La Physicienne, La Coquille, etc. As fast as new collections arrived from the explorations of several travelling naturalists, such as Durville, Goudot, Pilate, Sallé, d'Orbigny, Claussen, Ghiesbreght, Saint-Hilaire, and others, Macquart published new supplements to his work.

In 1845 he visited Switzerland again, calling on Perty in Berne, and thence passed to Germany. Returning to France, he put his newly acquired entomological collections in order, and returned to his work of classifying the exotic flies.

In 1850 he wrote a book on the "Facultés intérieures des animaux invertébrés", in whose introduction he published an autobiography of 82 pages.

Macquart was elected fellow of the entomological and scientific societies of France, Linnean, Normandy, Bordeaux, Turin, Lyon, Zurich, Malta. Stettin, and others. He died in 1855, the year of publication of the 5th supplement of his "Diptères exotiques nouveaux ou peu connus."

\section{Blanchard}

Charles Emile Blanchard, to whom was given the Diptera section of Gay's "Historia fisica y politica de Chile", was born in Paris in 6 March 1819. His father was a painter of natural history objects. When 14 years old, Blanchard entered the Paris Museum, in the entonological laboratory of Audouin. After the death of Audouin, Blanchard had Milne-Edwards as superior. As Blanchard had no academic title, he was a temporary employee, charged only wilh material tasks. However, he was able to learn Latin, English, German, drawing, painting, and to acquire some knowledge of natural history. In 1838 he was appointed "préparateur", and promoted to "aide-naturaliste" in 1841. In 1844 Milne-Edwards and Quatrefages went to the coasts of Sicily to investigate the marine fauna. Blanchard was appointed a member of the expedition, which gave him some importance in the scientific world. In 1862 he was elected to the French Academy of Sciences, and "profésseur administratif" of the Paris Museum. After his 40th year of life he gradually became blind, and this had a noticeable influence upon his work. He died on 11 February 1900 at $\$ 1$ years of age (Gaudry, 1900). 


\section{Coquerel}

Charles Coquerel, who described the myasis-producing Cochliomyia hominivorax, was born in Amsterdam. Holland, on 2 December 1822. the son of Athanase Coquerel, a protestant preacher. He studied medicine and was also interested in entomology, being made a member of the French Entomological Society in 1843. In 1845 he entered the French royal nary as

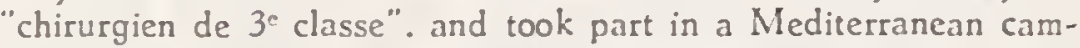
paign aboard the "Diadème".

In 1846 he visited Bourbon (Mauritius), Madagascar, Ceylon, Pondichery (in India), aboard the ships "Belle-Poulle" and "Prudente". In Madagascar especially he made some remarkable entomological discoveries.

Returning to France in 1847, he participated in the February revolution. Afterwards, he embarked in Toulon for La Martinique, in the West Indies, where he stayed collecting insects, and returned to France only in 1849, aboard the "Proserpin". which left him in Brest in March. Going then to Paris he obtained his title of "Doctor Medicinae". Going again to Toulon, he embarked once more as surgeon on the ship "Minerve".

In 1850 he obtained the grade of "chirurgien de 2 me. classe", and sailed aboard the "Provençal" to the Reunion Islands, where he collected a great quantity of insects. In 1852 he went again to Madagascar, there remaining for one year. After another short stay in the Reunion Islands, returned to France, arriving at Bordeaux on 18 September 1854 . For a while he worked in the hospital of Toulon, but after that, had to embark on the "Montezuma" to take part in the Crimean War (25 February 1855). As Count Dejean had done previously, Coquerel collected insects in the battlefield.

He returned to France in April 1856 with a group of soldiers sick with typhus. Following that, he was appointed to a hospital in Mers-el-Kebir, in Algeria, and there remained until May 1858. when he returned to Paris. At this time he published his paper on the Calliphoridae found in the frontal sinuses of men in Cayenne (1858a, 1858b, 1859b, 1859c).

War then broke out in Italy. Coquerel embarked again on 23 June 1859, and took part in several campaigns. On 10 May 1560, he was promoted to "chirurgien 1" classe", and while visiting the coasts of Syria had a violent attack of disentery, which forced hirs to return to France. where he remained for 6 months. After his convalescence, he visited the island Saint-Denis, ex- 
ploring it for three and a half years. After that he returned to France for the last time, in May 1866, very frail in health. He left the country to go to the Reunion Islands, where he died in 1867 (Fairmaire, 1868).

\section{Laboulbène}

Joseph Alexandre Laboulbène, born in Agen on 25 August 1825 is of interest to us only for his papers on Dermatobia and Cochliomyia (1860,1861, 1868, 1883, 1889). He had no inclination to the trade of inerchant. followed by his father, and leaving his native town in September 1845, went to Paris, with Léon Dufour and his two sons, in whose company he intended to study medicine.

He studied in several hospitals in Paris, and obtained his title of "Doctor Medicinae" in 8 March 1854. He followed a medical career, becoming professor of History of Medicine and Surgery in 1879. He published several papers on entomology, but more especially on parasitic Cuterebridae and Calliphoridae. He died in Saint-Denis d'Anjou (Mayenne), on 7 December 1898. at the end of a painful paralysis (Fairmaire, 1906; Blanchard, 1899).

\section{Bigot}

Information about Jacques Marie Frangille Bigot and his collections is very meager. He was born in 1818, in 1844 was elected fellow of the "Société Entomologique de France", and seems to have possessed one of the best collections of Diptera ever gathered. As Aldrich (1905: ii) points out, "Bigot's main work (...) is in the form of a long series of articles in the Annales Soc. ent. France $(.$.$) interspersed chronologically with fragments in the Bulletin of$ the same society. Owing to Bigot's peculiar. complicated and inconsistent system of numbering his contributions, it has been almost impossible for me to find them all, but I believe I have succeeded. (...). Sometimes his Roman numerals stop and remain the same for several papers, then again the numbering in "parts" becomes stationary while the other goes on, and in two cases two papers have both the same."

Bigot published two large series, the "Essai d'une classification générale et synoptique de lordre des Insectes Diptères", and the "Diptères nouveaux ou peu connus". He also studied the 
Diptera collected by Sagra in Cuba (1857a) and those collected by the Mission Scientifique du Cap Horn (1888).

He started publishing in 1852, and the last of his papers which interests us is dated 1889.

Osten Sacken was particularly resentful of Bigot's descriptive work. As Alexander (1969:13) says: "On a visit to Paris he (Osten Sacken) called on the latter (Bigot) and personally informed him that while he (Bigot) was doing a useful work in forming a large collection, particularly of the exotic species. "... he should renounce descriptive work, for which he was not competent. I expressed my opinion in the strongest terms, concluding with the words: "If all your publications could be suppressed it would be a gain for science".

Bigot's large and valuable collection of Diptera (which included some of Macquart's types) was later acquired by G. H. Verrall, and is now deposited in the British Museum (Natural History).

\section{References}

Aldrich. J. M.

1905. A catalogue of North American Diptera. Smithson. Misc. Coll. $46(2=$ publ. 1444$): 1.680$.

Alexander, C. P.

1969. Baron Osten Sacken and his influence on American dipterology: Ann. Rev. Ent. 14: 1-18, portrait.

Anonymous

157t. (Guérin-Méneville, biographical note). Ann. Soc. Ent. France (5) 1 : $: 5-8, x x^{2} \times 1 \%$

Bigot. J. M. F.

1954. Fssai diune classification générale et synoptique de lordre des Insectes Diptẻres. III . Anr. Soc. Ent. France (3) 2 : 447-452.

1856. Essal diune elassification générale et synoptique de loordre des Insectes Diptères. IVe. Ann. Soc. Ens. France (3) \& : 51-91.

1557a. Dipteros. pp. 328-349. pl. 20 of insects and crustaceans, bound in vol. S, in R. de La Sagra, Historia fisica. politica y natural de la Isla de Cuba 7 : 371 pp. Paris, "1556". (This portion on Diptera was also published as pp. $735-529$ of the Firench edition. in Paris, $\$ 29$ pp.o 1857. The French and Spanish editions were 
said to have been issued simultaneously, the latter a translation from the former).

1857b. Diptères nouveaux provenant du Chili. Ann. Soc. Ent. France (3) $5: 42-72$.

1857c. Essai dune classification générale et synoptique de lordre des Insectes Diptères. Ve. Ann. Soc. Ent. France (3) 5 : 517-564.

1858. Essai d'une classification gẻnérale et synoptique de l'ordre des Insectes Dipteres. VIe Ann. Soc. Ent. France (3) 6 : 569-595.

1859a. Dipterorum aliquot nova gencra. Rev. Mag. Zool. (2) 11 : 305-315, pl. 11.

1859b. Essai d'une classification générale et synoptique de l'ordre des Insectes Diptẻres. VIIc. Ann. Soc. Ent. France (3) 7 : 201-231.

1875. Diptères nouveaux ou peu connus. áe partie, V : Asilides exotiques nouveaux; 5e partie, VI : Espéces exotiques nouvelles des genres Sphixea (Rondani) et Volucella (auctorum); 5e partie. VII : Especes nouvelles du genre Cyphomyia. Ann. Soc. Ent. France (5) $5: 237-248 ; 469-482 ; 483-488$.

1876a. Diptères nouveaux ou peu connus. 6e partie, VIII : Curie des Phasides (Phasidae, mihi). Gres Trichopoda (Macq.) et Bogosia (Rond.). Ann. Soc. Ent. France (5) $6: 389-400$.

1876b. (Diagnose d'un nouveau genre de Diptères : Paranthrax). Ann. Soc. Ent. France (5) 6 (Bull.) : Lxv.

1876c. (Diagnoses de quatre Diptéres exotiques nouveaux : Ommatius et Emphysomera). Ann. Soc. Ent. France (5) 6 (Bull.) : Lxxxi-Lxxx1:.

1577a. Diptères rouveaux ou peu connus. 7e partie, IX : Genre Somomyia (Rondani) Lucilia (Rob.-Desv.) Calliphora, Phormia, Chrysomyia (id.): Se partie, X : Genre Somomya (Rondani) Calliphora. Melinda. Mufetia, Lucilia, Chrysomyia (alias Microchrysa Rond.) Robineau-Desvoidy. Ann. Soc. Ent. France (5) $7: 35-48 ; 243-259$

1877b. Genus novum, Ortalidarum (Macq. Schin. et auctor.) vel Tanipezidarum (Rond.) vel Trypetidarum (J. Bigot). Ann. Soc. Ent. France (5) 7 (Bull.) : Xxvi-xxvit.

1878. Diptères nouveaux ou peu connus. 9e partie, XII : Genus Phumosia, Pyrellia, Cosmina. Ochromyia et Curtonevra: 9e partie. XIII : Genres Ocyptera (Latr.), Ocypterula, Exogaster (Rond.): 9e partic, XIV : Notes et mélanges: 10e partie, XV : Tribu des Asilidi curies des Laphridac et Dasypogonidac. Ann. Soc. Ent. France (5) $S: 31-40 ; 40-47 ; 45 ; 213-240 ; 401-446$.

1879a. Diptères nouveaux ou peu connus. 11e partie, XVI : Curiae Xylophagidarum et Stratiomydarum (Bigot). Ann. Soc, Ent. France (5) $9: 153-234$.

1879b. Note. Ann. Soc. Ent. France (5) 9 (Bull.) : L-LI.

1879c. (Diagnoses de trois genres nouveaux de Diptėres). Ann. Sac. Ent. France (5) 2 (Bull.) : Livit-Lxun. 
1880a. Diptères nouveaux ou peu connus. 12e partie, XVIII : Genres Plagiocera (Macq.), Formosia (Guérin) et Rutilia (Rob.-Desv.) Ann. Soc. Ent. France (5) $10: 85-89$

1850b. Diptères nouveaux ou peu connus. 14: partie, XXI : Syrphidi (mihi). - Genre Eristalis (Fabr.). Ann. Soc. Ent. France (5) $10: 213-230$.

1880c. (Description d'un genre nouveau et de nouvelles especes ¿Acanthomeridac Weideman [sic]). Ann. Soc. Ent. France (5) 10 (Bull.) : v-vi.

1850d. (Diagnoses de trois genres nouveaux de Diptères). Ann. Soc. Ent. France (5) 10 (Bull.) : xLvi-XLvm.

1880e. (Diagnose dun nouveau genre de Diptères de la tribu des Tachinidi : Psecacera). Ann. Soc. Ent. France (5) 10 (Bull.) : Lin.

1881. Diptères nouveaux ou peu connus. 16e partie, XXIll : Tribus Venestrinidorum. Ann. Soc. Ent. France (6) l: 13-2I.

1882a. Diptères nouveaux ou peu connus. 13e partie, XXVIII Acanthomeridae (Wiedemann. Dipt. exot.). Ann. Soc. Ent. France (6) 1 (1881) : $\$ 53-460$.

1882b. Diptères nouveaux ou peu connus. 19. partie. XXX. Genre Ctenostylum. Ann. Soc. Ent. Frasce (6) 2: 21-22.

1882c. (Descriptions de quatre genres nouveaux de la tribu des Syrphides (Syrphidac. auctorum), ainsi que celles de deux nouvelles especes). Ann. Soc. Ent. France (6) 2 (Bull.) LXI7I-LXI7I.

1852d. (Description de deux nouvelles espèces de Diptêres propres à la Californie, dont liune est le type dun genre nouveau). Ann. Soc. Ent. France (6) 2 (Bull.) : xc1-xcrl.

I852e. (Diagnoses de genres et especes inedits de Syrphides. Ire partic: $2 e$ partie: $3 e$ partic). Ann. Soc. Ent. France (6) 2 (Bull.) : cxiv-cxv: cxx-cxxi: cxxviii-cxxix.

1883a. Diptères nouveaux ou peu connus. 20e partie. XXXI : Genres Volucella (Geoffr., Hist. des Insectes, I76t) et Phalachromyia (Rondari, Esame d. var. spec. (d'Insetti Ditteri Brasiliani, Torino, I845): 21e partic, XXXIl : Syrphidi (Ire partic): 22e partie, XXXII : Syrphid (2e partie). Especes nouvelles, n* I: $23 e$ partic. XXXIl : Syrphidj $(2 e$ partic). Espices nouvelles. n* 1I. Ann. Soc. Fent. France (6) 3 : 61-8S: 22I-25s: 315-356: $535-560$.

1853b. (Description dun nouveau genre de Diptères de la tribu des Syrphides). Ann. Soc. Ent. France (6) 3 (Bull.) : xa--xx1

1853c. (Diagnose diun nouveau genre et dune nouvelle espice de Diptéres de la tribu des Aniomyzides [sic]). Ann. Snc. Ent. France (6) 3 (Bull.) : xxx.

155ta. Diptères nouveaux ou peu connus. t parile, XXXll : Syrphidi (2e partie). Especes nouvelles, $n^{\circ}$ lII. Ann. Soc. Ent. France $(6)+$ : 73.116. 
1884b. (Diagnoses diun genre et d'une espèce de Diptères). Ann. Soc. Ent. France (1853) (6) 3 (Bull.) : cvin-cix.

1884c. (Description d'un nouveau genre et diune nouvelle espêce de Diptères de la familie des Ortalidae). Ann. Soc. Ent. France (6) 4 (Bull.) : xxux.

1884d. (Description d'un nouveau genre et d'une nouvelle espèce de Diptères de la famille des Dexidae). Ann. Soc. Ent. France (6) \& (Bull.) : xxxvil.

1855a. Diptêres nouveaux ou peu connus, 25e partie, XXXIII Anthomyzides nouvelles. Anr. Soc. Ent. France (1884) (6) 4 : 263-304.

1855b. Diptères nouveaux ou peu connus. 27e partie, XXXV : Famille des Anomalocerati (mihi) (Coriacea, Pupipara, Nycteribidac, auctor). Ann. Soc. Ent. France (6) 5 : 225-246.

1885c. (Diagnoses de deux genres nouveaux de Diptères du groupe des Déxiaires). Ann. Soc. Ent. France (6) 5 (Bull.) : xxv-xxv1.

1855d. (Les diagnoses de deux genres rouveaux de Diptères appartenant à la famille des Ortalidae). Ann. Soc. Ent. France (6) 5 (Bull.) : CLXV-CLXVI.

1886a. Diptères nouveaux ou peu connus. 29e partie, XXXVII : ler. Essai dine classification synoptique du groupe des Tanypezidi (mihi) et description de genres et despéces inédits; 2e (suite). Ann. Soc. Ent. France (6) $6: 257-302: 369-392$.

1856b. Diagnoses nouvelles d'un genre et d.une especce de l'ordre des Diptẻres). Ann. Soc, Ent. France (6) 6 (Bull.) : CII-Crv.

1857a. Diptères nouveaux ou peu connus. 31e partie, XXXIX : Descriptions de nouvelles esperces de Stratiomydi et de Conopsidi: 32e partic. XL : Descriptions de nouvelles espèces de Myopidi. Ann. Soc. Ent. Franee (6) 7 : 20-46: 203-208.

1887b (Diagnoses de quelques especes nouvelles de Diptères). Ann. Soc. En:. France (6) 7 (Bull.) : cxxisi-cxull.

1857c. (Diagnoses abrégées de quelques Diptères nouveaux, provenant de l'Amérique du Nord). Ann. Soc. Ent. France (6) 7 (Bull.) : CLOOXX-CLOOOXI.

1855a. Diptéres, pp. 1-45. pls, 1-\% in Ministéres de la Marine et de Instruction Publique, Mission Scientifique du Cap Horn, 1.592-1SS3. 6 (Zoologie), 2me Partie. Paris, "1891".

1885b. Diptères nouveaux ou peu connus. $33^{\mathrm{e}}$ partie, XLI : Tachinidae: 3łe partie. XIII : Diagnoses de nouvelles espèces. Ann. Soc. En: France (6) S : 77-101; 253-270.

1858e. (Noies critiques sur les Diptères). Ann. Soc. Ent. France (6) $S$ (Bull.) : xarv.

1555d. (Dlagnoses despices nouvelles de Dolichopodi). Ann. Soc. Ent. France (6) \& (Bull.) : vilx-xxx. 
1889a. Diptères nouveaux ou peu connus. 34́e partie, XLII : Empidi; 35 e partic, XLIII : Cyrtidi: 35 e partic, XLIV : Therevidi. Ann. Soc. Ent. France (6) 9 : 111-13t; 313-320; $321-328$.

1889b. (Novum genus Dipterorum ex Trypetidis, genus Chetostomac (Rondani) sat vicinum). Ann. Soc. Ent. France (6) 9 (Bull.) : $\mathrm{xxLx}-\mathrm{xxx}$.

1889c. (Change of generic name). Ann. Soc. Ent. France (6) 9 (Bull.) : xcin.

1859d. (Note on relationships of Archilestes and synonymy; change of generic name). Ann. Soc. Ent. France (6) 9 (Bull.) : CLxxwn.

1590a. Diptẻres nouveaux ou peu connus. 36e partie, XLV : Dolichopodi. Essai dune ciassification genèrale. Ann. Soc. Ent. France (6) $10: 261-296$.

1890b. (Change of generic name). Wien. ent. Ztg. $9: 96$.

1892a. Diptères nouveaux ou peu connus. 37 e partic. XLV1 : Bombylidi (mihi). Ann. Soc. Ent. France 61:321-376.

1892b. Descriptions de Diptères nouveaux. Tabanidi. Mém. Soc. Zool. France $5: 602-691$.

1592c. Nova genera dipterorum. Wien. ent. Ztg. 11 : 161-162.

1892d. Description diune espice nouvelle de Diptère parasite de Costa Rica. The Hummingbird 2 (7) : 19.

Blanchard, E.

1852. Orden 1X. Dipteros, pp. 327-468, in C. Gay. ed., Historia fisica y politica de Chile. Zoologia 7 : 471 np. Paris.

Blanchard, R.

1899. Notices biographiques. IV. Alexandre Laboultene. Arch. Parasitol. Paris 2 : 343-355, portrait.

Coquerel, C.

1558a. Notes sur les larves apparterant à une nouvelle espece de Diptère, developpe dans les sinus frontaux de l'homme. a Cayerne. Ann. Soc. Ent. France (3) 6 : 171-176. pl. 4, fig. 2.

1855b. Dis larves de diptères développées dans les sinus frontaux de l'homme a Cayenne, Lacilia hominivorar. Arch. Gern. de Méd. (5) $11: 513$.

1859a. Note sur une larve dOestride extraite du bras dun howse a Cayense. Rev. ef Mag. Zool. (2) 11 : 356-36t.

1859b. Sur un nouveau cas de roort produit par les larves de la Lasilia hominitorar. Arch. Gin. Med. (5) $13: 655$. 
1859c. Nouveau cas de mort produit par le Lucilia hominivorax et description de la larve de ce diptère. Ann. Soc. Ent. France (3) 7 : 233-237, pl. 6, fig. 1 .

Essig, E. O.

1931. A history of entomology. 11I +1029 pp., 263 figs. The MacMillan Co., New York.

Fairmaire, L.

1868. Notice nėcrologique sur Charles Coquerel. Ann. Soc. Ent. France (t) $8: 301-308$.

1906. Notice nécrologique sur le Dr. Joseph-Alexandre Laboulbène. Ann. Soc. Ent. France 75 : 63-66.

Gaudry, M. A.

1900. Discours-nécrologique de Blanchard. Bull. Mus. Hist. Nat. Paris 1900 (2) : 53-54.

Guérin-Méneville, F. E.

1831. Pls. 20-21 (= livrs. 23-24, part), in L. I. Duperrey, ed., Voyagc autour du monde sur la corvette de sa majestè La Coquille. Zoologic, Atlas, Insectes, 21 pls. Paris.

1835. Pls. 92-104 (= livrs. ?), in his lconographic du régne animal de G. Cuvier 2 (Planches des animaux invertèbrês, Insectes), 104 pls. Paris.

1835. Premiẻre division. Crustacés, arachnides et insectes. Div. 1, pp. 1-216, 217-319 (= livrs. 25, 26), in L. I. Duperrey, ed., Voyage autour du monde sur la corvette de sa majesté la Coquille. Zoologic 2 (2). Paris.

1844. Dousième ordre. Les Diptères, pp. 531-559 (= livr. 50), in his Iconographre du règne animal de G. Cuvier 3 (Texte explicatif, Insectes) : 576 pp. (= livrs. 45-50). Paris.

1829-1844. Iconographic dus régne animal de G. Cuvier, ou répresentation daprès nature de lune des especes les plus remarquables et souvent non encore figurées de chaque genre d"animaux, 3 vols. Paris.

Laboulbene, J. A.

1860. Rapport sur une larve d'oestride extraite de la peau d'un homme a Cayenne. Mém. Soc. Biol. (3) 2 : 161.

1861. Description et figure diune larve d'oestride de Cayenne. Ann. Soc. Ens. France (i) 1 : 249.

1865. Lucilia hominizorax observẻe au Mexique. Ann. Soc. Ent. France (t) $S$ (Bull.) : xxxit. 
1883. Examen de la larve vivante dun insecte diptère du Brésil (Dermatobia noxialis), observée à Paris. Bull. Acad. Méd. (2) $12: 729$

1889. Larve de Dermatobia sortie dune plaie humaine. Ann. Soc. Ent. France 64 (Buil.) : cccxr:

Macquart, J.

1834. Histoire naturelle des Insectes. - Diptères. Tome premicr. Diptera 1 : 578 pp., 12 pls., (in N. E. Roret, ed., Collection des suites a Button). Paris.

1835. Histoire naturelle des Insectes. - Diptères. Tome deuxiẻme. Diptera 2 : 703 pp., 12 pls., (in N. E. Roret, ed., Collection des suites a Buffor). Paris.

1839a. Diptères exotiques nouveaux ou peu connus. Mém. Soc. Roy. des Sci., de TAgr. et des Arts Lille 1835 (2) : 9-225. 25 pls. (Also published separately, as vol. 1, pt. 1, pp. 5-221, 25 pls., Paris, 1838).

1838b. Diptères crotiques nouveaux ou peu connus $l$ (2) : 5-207, It pls. Paris. (Also published in Mém. Soc. Roy. des Sci., de I Agr. et des Arts Lille 1835 (3) : 121-323, it pls.o 1839).

18 t0. Diptères exotiques nouveaux ou peu connus 2 (1) : 5-135. 21 pls., Paris. (Also published in Mém. Soc. Roy. des Sei., de TAgr. ef des Arts Lille 1540: 253-413, 21 pls., 1841).

1842. Diptères exotiques nouveaux ou peu connus. Mém. Soc. Roy. des Sci. de l'Arg. et des Arts Lille 1841 (1) : 65.200, 22 pis. (Also published as vol. 2. pt. 2, p. 5-140, 22 pls., Paris, 1842).

1843a. Diptères exotiques nouveaux ou peu connus. Mém. Soc. Roy. des Sci., de TAgr. et des Arts Lille 1S42 : 162-460, 26 pls. (Also published separately as vol. 2, pt. 3. pp. 5.304, 36 pls. Paris, 18+3).

1843b. Description diun nouveau genre dinsectes Diptires. Ann. Soc. Ens. France (2) $l$ : 59-63. 1 pl.

1846. Diptères exotiques nouveaux ou peu cornus. Ier Supplément. Mém. Soc. Roy. des Sci., de rAgr. et des Arts Lille (1845) $15 \frac{14}{1}$ : 133-364. 20 pls. (Also separately published. as Supplément I. pp. 5-235, 20 pls., Paris, 1546).

1817. Diptères exotiques nouveaux ou peu connus. 2e supplémen:. Mém. Soc, Roy. des Sci., de TAgr. et des Arts Lille 1S\$6 : 21-120. 6 pls. (Also separately prblished, as Supplémen: 1I. pp. 5-104. 6 pls. Paris, ? $18+7$ ).

15tS. Diptères exotiques nouveaux ou peu connus. Suite du 2 me supplément i.e.. 3e supplexent. Mem. Soc. Roy. des Sei., de PAgr. e: des Arts Lille 1547 (2) : 161.237. 7 pls. (Also separa. tely published, as supplémen: III. pp. 1.77. T pls., Paris, 18t5).

1850. Dipteres exotiques nouveaux ou peu conaus. fe supplemen: [part]. Mtrm. Soc. des Sci. de PAgr. et des Airis Lille 1S\$9: 309-165

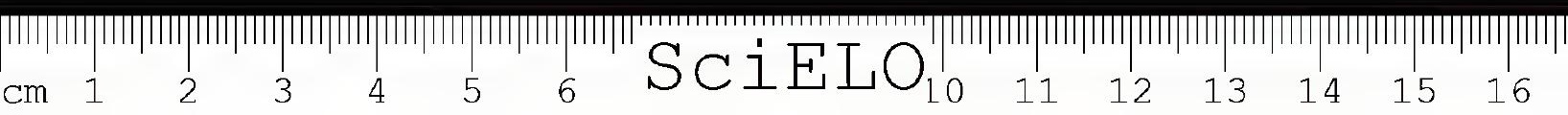


(text), 466-479 (explanation of figs., index), pls. 1-14. (Also published separately as Supplément IV [part], pp. 5-161 (text), Paris, ? 1850)

1850a. Facultés intérieures des animaux invertébrés, Ixxxii [Macquart's autobiography] + 272 pp. Imprimérie de L. Danel, Lille. [Reprinted from the Mém. Soc. des Sci., de I'Agric. et des Arts, Lille].

1851. Dipteres exotiques nouveaux ou peu connus. Suite du 4e supolément. Mém. Soc. Natl. des Sci., de l'Agr. et des Arts Lille 1850 : 134-282 (text), 283-294 (explanation of figs., index, pls. 15-28. (Also published separately as Supplément IV part, pp. 161-309 (text), 317-323 (explanation of figs.), 324-336 (combined index of the 2 parts of this supplement), pls. 15-28, Paris, 1851).

1855. Diptères exotiques nouveaux ou peu connus. 5e supplément. Mèm. Soc. Imp. des Sci., de l'Agr. et des Arts Lille 1854: 25-156, 7 pls.

Olivier, G. A.

1811-1812. Irsects [(i.e.. Arthropoda), pt. 5] vol. $8: 1-360$ (= livr. ?), 1811; pp. 361-722 (= livr. 77), 1812, in Sociète de Gens de Lettres, de Savans et d'Artistes, Encyclopédic méthodiquc. Histoire Naturelle. Paris.

Osten Sacken, C. R.

1893. Two critical remarks about the recently-published third part of the Muscaria-Schizometopa of MM. Brauer and Bergenstamm; also a notice on Robineau-Desvoidy. Berlin. ent. Ztschr. 39 (t) : 350.386 .

Robineau-Desvoidy. J. B.

1830. Essai sur les Myodaires. Paris Inst. de France, Cl. des Sci. Math. et Phy's., Acad. Roy. des Sci., Mém. présentées par divers Savans (2) $2: 1-813$ 


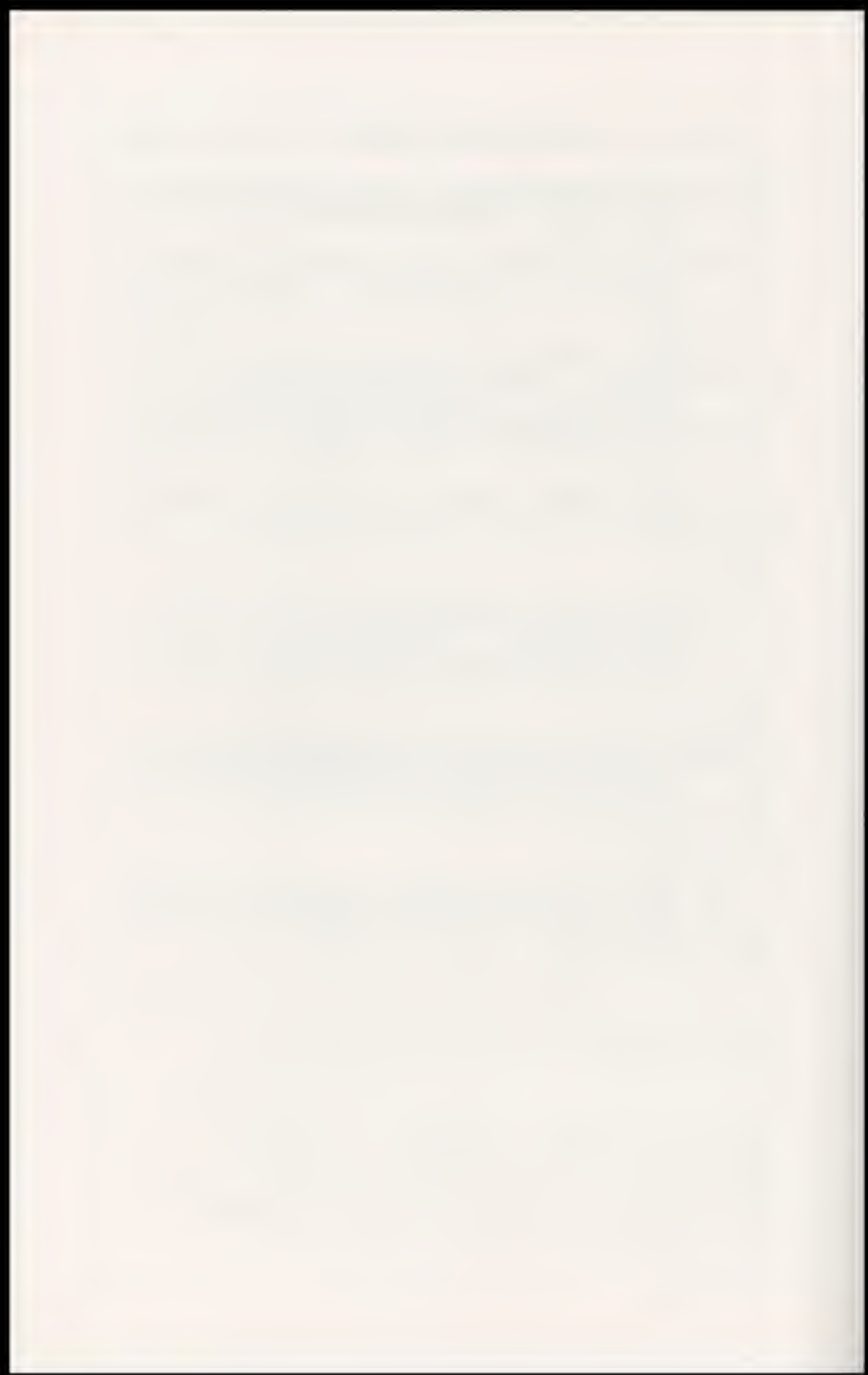




\section{Synopsis of countries and their respective zoological collectors}

\section{Antilles (Lesser)}

Rohr, 1757-1793 (especially St. Croix, but also visited other islands)

Richard, 1786 (Martinique, Guadeloupe, Antigua, Barbuda, Anguilla, St. Croix, Tortola. St. John. St. Thomas)

Smide, 1780's

Pflug. end of 18th century (St. Croix)

Porsström, 1805-1812 (St. Barthélemy, St. Thomas. St. Croix)

Plée, 1820-1825 (especially Martinique)

Hornbeck, 1825-18tt (St. Jean. St. Thomas, St. Croix)

Beaupertuis, around 1835 (Guadeloupe)

Hodjard (before 1830)

Mme. Rivoire, before 1838 (Martinique)

Castelnau, 1847 (Barbados, St. Lucia, Martinique, Guadeloupe, Antigua. Montserrat. St. Christopher. Tortola, St. Croix. St. Thomas)

Coguerel, 18\$8.1849 (Martinique)

\section{Argentina}

Banks 8 Solander, 1769 (Falklands. Capes of San Diego and San Vicente) Gaudichaud, Quoy. Gaimard \& Freycinet. 1820 (city of Buenos Aires)

Bescke (senior). 1821 (city of Buenos Aires)

Dumort d'Urville E Lesson. 1822 (city of Buenos Aires, Falklands) 
Sellow, 1822 (city of Buenos Aires)

La Touanne, 1826-1827 (Provinces of Mendoza, Córdoba, Santa Fé, and Buenos Aires)

Bougainville Fils, 1826 (Falklands)

Lacordaire, 1826, ?1828 (several provinces, and cily of Buenos Aires)

d'Orbigny, 1827-1829 (Provinees of Buenos Aires, Entre Rios and Corrientes; Carmer. de Patagones)

Gay, 1828 (city of Buenos Aires)

Laplace, 1831-1832 ("Tierra del Fuego")

Gaudichaud E Eydoux, 1836 (Puerto Deseado. Bahia de Todos los Santos)

?Fontaine, 1837 (cily of Buenos Aires)

Germain, ?1599 or ?1900 (city of Buenos Aires)

\section{Bolivia}

dOrbigny, 1830-1533 (all Departments, Tarija and Pando excepted)

Casteinau, 18\$5-1846 (Santa Cruz. Cochabamba, Chuquisaca, Potosi, Oruro, La $\mathrm{Paz}$ )

Pissis, 1845 (several regions)

Germain. ?1899 (Santa Cruz)

\section{Brazil}

Banks $\mathcal{E}$ Solander, 1769 (cily of Rio de Janeiro. Ilha Rasa)

Richard, 1785 (Bèlếm, Pará)

Sieber, 1831-?1812 (Almazonia)

Gomes, beginning of 19 th century (Bahia and Pernambuco)

Feijo. beginning of 19:h century (Cears)

Belerão, beginning of 19th century (Rio de Janeiro)

Langsdorff, 1803-1504 (Florianópolis). 1813-1820 (States of Rio de Janciro,

Minas Gerais). 1\$24-1825 (Minas Gerais). 1\$25-1829 (States of Săo

Paulo. Mato Grosso. Arazonas and Pará)

Freyreiss, 1514-1825 (States of Minas Gerais. Rio de Janeiro, Espirito Santo and Bahia)

Sellow: 1814-1831 (States of Guanabara, Rio de Jareiro, Espirito Santo. Bahia. Minas Gerais. Sło Paulo. Parass. Santa Catarisa and Rio Grande do Sul)

Westir. around 1814 (State of Guarabara)

Eschscholt:, 1\$15.1517 (Florianópolis and coast of Santa Catarina)

Dilalande, $1 \$ 16$ (Guanabara, Rio de Janeiro)

Sain:-Hilaire, 1816-1822 (States of Guasabara. Rio de Jareiro. Espirito Santo. Goiás. Minas Gerais. Săo Paulo, Paraná, Sania Catarina and Rio Grande do Sul)

MIkån. 1817-1819 (Guanabara, Rio de Janeiro coast)

Połl. 1\$17-1821 (Gramabara, Rio de Janeiro, Minas Gerais. Golás)

Spix E. Marius, 1\$17-1520 (Guanaba:a, Rlo de Janeiro. Såo Paulo. Miras Gerais. Bahia, Pernazbuco, Piaul, Marashäo, Pass, Amazoras) 
Natterer, 1817-1835 (Guanabara, Rio de Janeiro, Săo Paulo, Paraná, Mato Grosso. Amazonas, Pará)

Gaudichaud, Quoy, Gaimard E Freycinet, 1817-1818, 1820 (city of Rio de Janeiro and vicinity)

Olfers, 1818-1819 (Guanabara, Rio de Janeiro, Minas Gerais, São Paulo) Kamerlacher, 1818-1819 (São Paulo)

Bescke (senior). 1821 (Salvador in Bahia, Rio de Janeiro in Guanabara) Mẻnétriés, 1822-1825 (Guanabara, Rio de Janeiro, São Paulo, Minas Gerais) Claussen, ?1822-1840 (especially Minas Gerais)

Dumont d'Urville \& Lesson, 1822 (Florianópolis and coast of Santa Catarina) Leschennault \& Doumerc, 1823 (Rio de Janeiro in Guanabara, Salvador in Bahia)

Lund, 1825-1829 (Guanabara, Rio de Janeiro)

Bougainville Fils, 1826 (city of Rio de Janeiro)

Lacordaire, 21826 (Rio de Janeiro. Minas Gerais. Săo Paulo)

d'Orbigny: 1826 (cily of Rio de Janeiro)

Gay, 1828 (city of Rio de Janeiro)

Bescke Jr., ?1831-1851 (State of Rin de Janeiro, especially Nova Friburgo)

Gaudichaud, 1831, 1836 (Salvador in Bahia, city of Rio de Janeiro, Santos in Săo Paulo. Florianópolis in Santa Catarina)

Vauthier, 1831-1\$33 (Guanabara, Rio de Janeiro, Minas Gerais)

Laplace, 1832 (Iihas dos Ratos in the Bay of Guanabara)

Ghiesbreght. Funck Eq Linden. 1835-1837 (Guanabara, Rio de Janeiro, Espirito Santo, Minas Gerais, São Paulo)

?Fontaine, 1837 (Fernando Noronha, Cabo Frio, city of Rio de Janeiro, Florianopolis)

Pissis, around IStl (Salvador in Bahia, Rio de Janeiro, São Paulo, Minas Gerais)

Castelnau. 15 $43-1845$ (Guanabara, Rio de Janeiro. Minas Gerais, Goiás. Mato Grosso), 1847 (Amazonas, Pará)

Mathan, ?1573-1893 (Pará, Amazonas)

Gourelle, 1584-1555 (Guanabara, Rio de Janeiro. Minas Gerais, Bahia), 1889-1859 (Bahia), 1892-1893 (Pernambuco). 1895 (Pernambuco. Pàra). 1895-1899 (São Paulo, Rio de Janeiro, Guanabara, Minas Gerais). 1901-1903 (Guanabara, Rio de Janeiro, Minas Gerais)

Gerrain, 1857, ?1899. (Mato Grosso) and 1887 (Amazonia)

\section{Central America}

Sallé (?)

Ghiesbreght. Funck \& Linden. 18j5-18j9 (Guatamala)

Boucard (several regions), in 1977 Costa Rica

Chile

Eschscholtz, 1817 (Concepción)

Dismoni dUrvilie E Lesson. 1823 (Concepción) 
Bougainville Fils, 1825 (Valparaiso, Santiago and nearby places)

Lacordaire (?1828)

Gay, 1828-1832 (Colchagua, Juán Fernåndez), 1834-18t2 (Valdivia, Chiloé. Coquimbo, Santiago, Talca, Maule, Concepción, etc.)

d'Orbigny, 1830 (Valparaiso), 1833 (Arica and Valparaiso)

Gaudichaud \& Eydoux, 1831. 1833 (Valparaiso)

Laplace, 1831 (Valparaiso, Masafuera)

?Fontaine, 1837, 1838 (Valparaiso, I. San Gallán, I. San Lorenzo; Valparaiso, Islas Desaventuradas, I. San Ambrosio, I. San Félix)

Pissis, 1848-1867

Germain, 1853-1913

Boucard (?)

\section{Colombia}

Humbold: \& Bonpland, 1801-1802 (along the Magdalena, and south to Ecuador)

Goudot, ?1827-18 $\$ 3$ (several regions)

Linden, 1842, 1844 (coast, Santa Marta Region, basin of the Magdalena, south to Bogotà and other regions)

Bouchard, around 1860

Mathan, ?1900

Lebas, before 1840

Sallé (?)

Boucard (2)

\section{Cuba}

Humboldt E Bonpland, 1800-1801

Sagra, $182 t-1835$

Ghiesbreght, Funck $\mathcal{E}$ Linden, 1837-1838 (northern and western districts)

Linden, 18tt (eastern districts)

Gundlach, 1838-1890

Poey. 18:5-1891

\section{Ecuador}

Humboidt E Bonpland, 1802

?Fontaine, 1838 (Galåpagos)

Lebas, before 1840

Mathan, ?I857-1893

\section{French Guiana}

Richard, 1781-1789 (Cayenze and neighborhoods)

Rohr, 1783 
Palisot de Beauvois, ?1790 (Cayenne)

Bosc, ?1795 (?Cayenne)

Leschenault \& Doumerc, 1823-182f (Cayenne, La Mana R., Oyapock R.)

Lacordairc. $1830-1831$

Banon, ?1830

Leprieur, ?1830-1833 (Cayenne and neighborhood, Oyapock R.)

Castelnau, 1847 (coast)

\section{Guyana}

Smidt, $1780^{\circ}$ s (Demerara and Essequibo R.)

Castelnau, 1847 (coast)

\section{Hispaniola}

Richard, 1786 (Haiti)

Palisot de Beauvois (?1790-1794)

\section{Jamaica}

Rohr, 1783

?Yeats (?)

Linden, $184 i$

\section{Mexico}

Humboldt \& Bonpland, 1803-1804

Deppe. $182 i-1827$

Deppe E Schicde, $1828-1830$

?Fontaine, 1837 (western coast : Mazatlán. Acapulco, etc.)

Ghicsbreght, Funck $\mathcal{E}$ Linden, 1838-18 10

Pilate, 18 $45-18+6,1849-1852$ (Yucatán)

Dugès, 1853-1895 (Guanajuato)

Sallẻ (?)

Boucard (?)

\section{Paraguay}

Germain (?1899)

\section{Peru}

Humboldt \& Bonpland, 1802

Dumont d'Urville \& Lesson, 1823 (Callao, Payta)

Gaudichaud E Eydoux, 1831, 1836 (Cobija)

d'Orbigny, 1833 (Islay, Tacna, Callao, Lima)

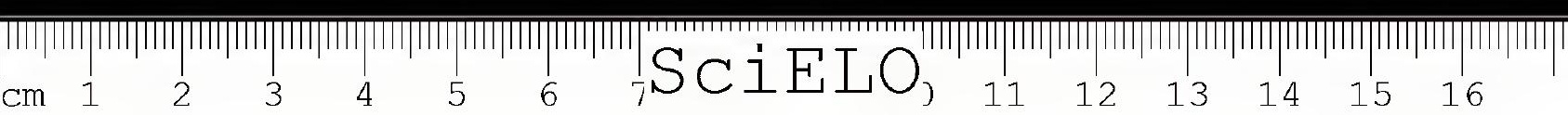




\section{ESSAYS ON THE HISTORY OF NEOTROPICAL DIPTEROLOGY}

?Fontaine, 1837 (Callao, Lima), 1838 (Callao, Payta, etc.)

Gay, 1839 (Tingo Maria, Cuzco, Valley of Santa Ana, R. Urubamba, Arequipa, Lima, Callao)

Castelnau, 1845-1846 (Puno, Arequipa, Ica, Junin, Huancavelica, Ayacucho, Apurimac, etc.)

Mathan, ?1883-1887

\section{Puerto Rico}

Rohr, 1783

Richard, 1786

Plée, 1822-1823

Hornbeck, between 1825 and 1844 (and also Island of Crabs)

Gundlach, 1873, 1875

\section{Surinam}

Dahiberg, 1746-1881 (Paramaribo and neighborhood)

Rolander, 1755-1756 (Paramaribo and Commewijne R.)

Leschenault, 1823

Castelnau, 1847 (coast)

\section{Uruguay}

Saint-Hilaire, 1820-1821 (Montevideo, Maldonado, western part of the country, along Uruguay R.)

Sellow, 1821-1823 (Montevideo, Maldonado, western part of the country along the Uruguay R.)

La Touanne, 1826 (Montevideo)

d'Orbigny, 1826-1827

Lacordaire, ?1826, ?1830 (Montevideo)

Gay, 1828 (Montevideo)

Gaudichaud, 1836 (Montevideo)

?Fontaine, 1837 (Montevideo)

\section{Venezuela}

Loefling. $175+-1756$ (coast, region below confluence of Rivers Orinoco and Caroni)

Humboldt \& Bonpland, 1779-1800 (coast, Orinoco basin)

Plée, $182 t$ (coast)

Linden, 1841-1843 (north of the Orinoco)

Rojas, ?1850-1856 (Caracas, San Fernando de Apure)

Sallé (?) 


\section{Index}

(Names of collectors in small capitals)

Adet. 19

Adolf Frederick, King of Sweden $-4.7$

Adrien - 150

Agrel, J. G. - 10

Aguilera - 181

Albin, S. - 26

Alcântara, D. Pedro de -53.60

Aldrovandi - 26

Alexander I. Czar of Russia - 53 . 54

Alioni - 26

Allemand. - 26

Almeida, J. R. de - 116

Alstroemer, Baron von - 11

Altenstein. K. F. von $-59,60,69$, 71

d'Amarzit, J. J. S. - 43

Ambrosius of Flensborg - 27

Andrada e Silva, J. B. - 145

Anemuria, Bishop of - 144

Angelini - 55

Arago, J. - 124, 126

Arango - 181

Audouin - 191, 193
Balbis, G. B. -148

BANKS, J. - 11, 15-16, 26, 27, 29 33, 57

BANON - 134, 192

Baudin, N. - 124. 130

Beaumont, Archbishop of Paris 17

BEAUPERTUIS - 192

Bedloo, J. C. -7

BELTRÃO - 49

Besche - see BESCKE

BESCKE, C. F. - 87, 110, 112

BESCKE, C. H. - 87, 110,112, 145

Beske - see BESCKE

Beské - see BESCKE

Bibron - 180

Bichat - 35

Bigot, J. M. F. - 159, 180, 195196

Blainville - 191

Blanchard, C. E. - 193

Blumenbach, J. F. -34

Boerhaave, H. - 2

Bolivar, S. - 42

BONPLAND, A. J. G. - 31-13. 112 
Bonpland, M. S. - 34, 57, 77, 153

BosC, L. A. G. - 20, 28, 29

Bosc d'Antic, P. - 20

BOUCARD, A. -179

BOUCHARD, P. - 166

Bougainville - 34

BOUGANVILLE, BARON, JR. -131 . 144

Boussingault, J. B. J. D. - 166

Brandis, B. - 89

Brooks, T. - 183

Broussonet. P. M. A. - 187

Brouwer, C. -7

Bruguière - 188

Brullé - 191

Buch. L. von - 34

Buchan - 16, 17

Buchberger, J. - 61. 62

Buffon - 16

Bullock. N. - 105

Bullock. N.. Jr. - 105

Bullock, W. - 104, 106

Burmeister, H. - 88

Bustillos. J. V. -148

Caldas, J. de - 39

Caldeira, M. C. -50

Camara, M. de A. - 144

Cambassèdes - 1 is

Campe, J. H. - 33

Camper. N. du - 131

Candolle - $f$

Cantero, J. G. - 182

Carcel - 191

Carrasco, M. - 141

Carvajal y Lencastre. J. de - 5

Castel, J. de D. - 5

CASTELNAU, F. L. $\therefore$. DE C. DE L. 91, 149-159, 191, 193

Castries - 17

Catherina. Empress of Russia - 8. 11

Celsius, O. - 1

Cerisy, L. de - 187

Chamberlain -65

Chamisso de Boncourt, L. C. A. $-51$

Champion - 151

Capuis, P. - 148

Charles 1II, King of Spain - 10. 39

Charles IV. King of Spain - 35 . 36, 49

Chaudoir, Baron de -178

Chevalier - 126, 127
Christian VIII, King of Denuark - 90.91.102. 146

CLAUSSEN. P. - 90, 151, 193

Clemond-Tonerre, Marquis of 128

Clifford, G. - 2

Cocteau - 180

Condal, A. - 5

Cook, J. - 15, 26, 33

Coquerel, A. - 194

Coquerel. C. - 194

CORDUA - 112

Coutinho, F. M. de S. - 38

Cramer, C. $\sim 27$

Crẻvalix - 147

Cullen - 26

Cunha, A. A., Count da -16

Cuvicr, Baron - 34, 52, 57, 90. 128, 130, 131, 148, 180

DAHLBERG, 3. 7. -7.8

Darondeau - 127

De Geer, Baron - 8. 9

DELALANDE, P. - 115-116,146, 190 DEPPE, F. - 103-107, 110,112

Deppe, $W-104$

Desfontaines - 28. 35. 12\%, 128 . $1 \div 8$

Deville, E. - 150

DOUMERC. A. - 130-131, 190, 192

Dreusy - 123

Drury; D. - 10, 26, 27

Duché - 189

Dufour, L. - 195

DUGÉS, A. A. D. -179

Dumatroy - 126

Dumont d'Urville - 128. 187

Durville, Captain - 125, 193

Duperrey. L. I. - 128, 187

Egaña. M. - 149

Eltz, Count von - 61. 62

Emparån. V. - 36

Ender, T. - 61, 62, 65

Erichson, W. F. - 110

ESCHSCHOLTZ, 0. 6. - 51, 112

Eschwege, W. von - 117

d'Espagnac, Baron - 43

Etruria. Queen of - 49

EYDOUX - 126, 127

Fabricius, J. C. $-20,25-30,112$

Fairmaire, L. - 160

Fée - 149

FEIJÓ. J. DA S. - 4S. 11. 112 
Ferdinand VI, King of Spain - 4

Férussac - 191

Fisquet - 126

Flemming, Count von $-60,69,70$

Florence, $H .-54,55,56$

FONTANA, P. A. - 161-165, 192

Fontaine - see FONTANA

Forell, Baron - 35

Forster, G. - 34

FORSTRÖM, J. E. - 103,110

Fourcroy - 18, 28

Francia, Dictator of Paraguay 42

Francis, Emperor of Austria - 80

Freireiss - see FREYREISS

FREYCINET, L. C. DE S. - 121, 125 ,

PREYREISS, G. W. - $\mathbf{5 7 - 5 8 , 1 1 0 , 1 1 2}$

Friedrich 1, Emperor of Austria 60

Frübeck, F. J. - 61

Funck, N. - 176-178

Furtado, F. X. de M. - 4

Gaimard, J. P. - 124, 125

Garnot - 128

Gaubius - 26

GAUDICHAUD-BEAUPRÉ, c. - 80 $121-12 \mathrm{~T}, 146,192$

GAY, C. $-148-149,160,192,193$

GERMAIN, P. - 160-161

Gervais - 180

Ghiesbrecht - see GHIESBRECHT

GHIESBREGHT, A. B. - 176-178, 193

Ghisbrecht - see GIIIESBREGIIT

Godeffroy - 57

Godman - 178

Gomes, A. L. - 116, 117

COMES, F. A. $-18,111,112$

González, Father J. - 39

Goudin, L. - 5

GOUDOT, J. - 165, 193

COUNELLE, P. E. - 162-163

Gounelle, E. - 162

Gouriana, 157

Green - 17

Gregory - 26

Grill, C. - 5

Grimaldi, Marquis of -5

Gronovius, J. F. - 2

Guérin-Méneville, F. E. - 180 157, 192, 193

Guicherot - 180

GuNDLACII, I. C - 181-183

Gustav III, King of Sweden -8
Gustav Adolf IV, King of Sweden $-8$

Gutiérrez, N. J. - 182

Hasse, C. -54

Haüy - 57, 144

Heine, C. G. - 34

Henningsen, A. -25

Hesketh, R. - 68

Hodgard - see HOGARD

Hoffmannsegg. J. C., Count von $35,47,48,111$

HOGARD - 164, 190, 192

Holthuysen - 112

Hope -26

HOR NBECK, H. B. $-107,112$

Huet - 127

HUMBOLDT, F. H. A., Baron von $33-43,47,53,57,90,112,128$, 190

Hunter - 26, 27

Iturriaga, D. J. de $-4,5,7$

Iturrigaray, Count $\sim 41$

Jefferson, T. -41

Jimenez - 181

João V. Dom, Kin of Portugal $-4$

João, VI, Dom, King of Portugal - 49, 53, 60, 71, 145

Josephine, Empress of France 41

Junot, General - 49

Jussieu - 3, 28, 35, 57, 148, 150

KAMERLACHER, J. - 61, 80, 87

Karl-August, Grand Duke of Saxony- Weimar - 61

Kielche - 55

King. P. -76

Koenig - 57

Ko!lar, V. - 65

kotzebue, O. von - 51

Kratzenstein, C. G. - 9

Krug, L. - 183

Krusenstern, A. - 50, 65

Kunth, G. J. C. - 33

Laboulbène, J. A. - 195

Lacépéde - 20

Lacerda, A. C. de - 145

La Condamine - 5, 33

LACORDAIRE, J. T. - 133, 136, 159 , 192 


\section{ESSAYS ON THE HISTORY OF NEOTROPICAL DIPTEROLOGY}

Lagrange -34

Lamarck - 34, 35, 45, 57, 123

LANGSDORFF, BARON G. H. VON $50-51, \quad 52-56,65,110,116$, $119,124,145,150,151$

Laplace - 34

LAPLACE, C. P. T. - 147

Laroche - 43

La Salle, Captain - 126

Latreille, P. A. - 20, $43-45,52$, 126, 128, 191

Laugier - 144

Lauvergne -

Leach -57

Leadbeater - 104

IEBAS - 164, 192

Lefebvre, A. - 191

Lemoine, Cardinal - 44

Leopoldina Carolina Josefa, Archduchess of Austria - 0, 75. 80,146

IEPRIEUR, F. R M. $-147,192$

Lescaille, E. - 183

LESCHENAULT DE LA TOUR, L. T. $130-131,190,192$

Lesson, P - 128, 187

Lichtenstein, H. $-60,77,104,107$

Linden, J. J. - 176-178

Link - 60

Linnaeus, C. - 1-11, 16, 25

Linnaeus, C., Jr. - 9-11, 109

Linnẻ, C. - see Linnaeus

Loefling. E. - 4

LOEFLING, P. - 4. 7,36

Loevensterns, Baron von - 90

Louis XVI, King of France - 18

Louis XV11I, King of France 128

Louis Philippe, King of France 149

Lowson, 1. - 2

Lucas - 180

LUND, P. W. - S9-91, 112

Lund. T. -91

Luxemburg. Duke of -115

Macquart, P. J. M. - 116. 120, $146,147,159,190,191 \cdot 193$

Malepeyre - 44

Maller - 119

Manso, A. L. da S. - 145

Marcgrave, G. - 3

Marescot. A. S. Marquis of -190

Marialva, Marquis of - 60
Marie Antoniette, Quecm of France $-18$

MARTIUS, K. F. P. von $-61,65-69$, $77,99,111,145$

MATHAN, M. DE - 161

Maurieius, J. J. -7

Maximilian Joseph I, King of $\mathrm{Ba}$ varia $-61,111$

Meigen, J. W. - 192

MÉNÉTRLÉS, E. - 52, 53, 54

Merian, M. S. - 3

Metternich-Winneburg, Prince von - 60

MIKAN, J. C. $-61,118$

Milne-Edwards - 90, 193

Missiessy - 126

Monceaux - 189

Monkhouse - 17

Moraeus, J. - 2

Moraeus, S. E. - 2, 3

Morejón. R. de la P. - 181

Mühlfeld, M. von -112

Mutis, J. C. - 10, 39

Napoleon I. Emperor of France 34, 41. 49, 115

NATTERER, J. $-61,62,64,70,80-$ $87,120,145$

Néboux, A. S. - 165

Necker, - 17, 18

Neudenberg. Baron von -86

Neudenberg. G. von - $\$ 6$

Neveu. Baron von - 61, 62, 65 , 68

Nicholas 1, Czar of Russia - 53. 56

O'Higgins - 129

OLFERS, 1. P. W. M. VON $-69,78$, 112,118

Olivier, G. A. - 28, 187-158, 192 , 193

D'ORBIGNY, A. D. - 136-114, 180 , 193

d'Orcy, G. - 188

d'Osery, E -150

Otto, E. - 181

Ovalle, President of Chile - 148

Ovide, F. - 122

Palfy, Count von - 61, 65

PALISOT DE BEAUVOIS, A. M. P. J. BARON DE - 19,29, 190

Pallas, P. S. - 10

Parkinson - 16 
Pastor, B. -5

Pavón, J. - 35, 111

Pedro I, Emperor of Brazil - 145 , 146

Pedro II, Emperor of Brazil - 69 . 146

Perón - 124

Perty, J. A. M. - 110, 193

Pfeiffer, I. - 88

Pfeiffer, L. - 181

PFLUG, P. G. $-22,29$

Philippi, R. A. - 160

PILATE, L. - 175-176, 193

Piso, $W .-3$

Pissis, J. N. $-154,159$

Pissis, P. J. - 159

PLÉE, A. - 127-128, 192

POEY Y ALOY, F. - 180-181, 182. $182,190,192$

POHL, J. E. $-61,62-65,118$

Pontoppidan - 25

Portales, Minister of Chile - 148

Portugal e Castro, M. de - 66

PRÉGENT - 146

Presas - 181

Quatrefages - 193

QuOY, J. R. C. $-121,125$

Raddi, G. - 61, 62, 118

Reaumur, R. A. F. de -3

Règo, M. do $-\delta 5$

Reuterholm, N. -2

Rezende, E. R. de - 145

Ribeiro, B. M. -74

Richard, C. -17

RICHARD, L. C. M. - 17-18, 29, 124. 192

Riedel, L. - 54, 55, 56, 90

Rivadavia, B . 42

Rivas, M. de -52

RIVolre, Mme. - 166, 192

Rivoire-Théodosie — see RIVOIRE

Rivoli. Duke of - 136

Roberg - 3

Robespierre - 20

Robineau-Desvoidy, J. B. - 116 , 120, $188-190,192$

ROHR, J. P. B. VON - 20.21, 29

Rojas. J. M. - 163

ROJAS, M. A. -163

Roland - 20, 23, 183

ROLANDER, D. -7.9

Romanzoff, Count von - 51

Roret, N. E. - 191
Rosen, N. - 3

Rottböll - 9

Roulin, T. C. -166

Rousseau, J. J. - 33

Roxas, M. - 6

Rudbeck, O. - 1, 3

Rubzoff, N. - 54, 55, 56

Rudolphi - 71

Rugendas, M. - 52, 53, 54

Ruiz, H. - 35, 111

Sack, Count von - 104, 106

SAGRA, R. DE LA - 197-180, 192

Saint-Fargeau, L. de - 191

SAINT-HILAIRE, A. F. C. P. DE -52 $115-123,146,190,193$

Saint-Hilaire G. - 34, 191

Saint Vincent, B. de -44

SALLĖ, A. - 164, 178, 193

Salvador y Carmona, B. - 5

Salvin - 178

Sauvalle, F. A. - 182

Schau - 9

Scheindenburg. D. -7

Schiede, IW. - 107

Schjödte - 21

Schlim, L. J. -177

Schmidt - see SMIDT

Schönfeld, Count von -61

Schott, H. W. - 61, 64

Schreber - 26

Schreibers, K. von - 60, 62

Schröckinger, J. - 86

SCHüCH, R. - 61, 146

Scopoli -27

Sehestedt, C. - 21, 29, 30

Sello - see sELLow

Sello, C. J. -56

Sello, J. W. -57

SELLOW, F. - 34, 56-60, 69-80, $99-102,110,112,120,126$, 145. 146

Serville, A. - 191

SIEBER, F. W. - 48, 111, 112

Silveira, L. M. da -51

SILVEIRA-CALDEIRA, J. DA S. - 132 , 141-147, 192

Sims, J. - 57

SMIDT - 21.22, 29

Smidt, A. L. -21

Smidt, J. C. - 21

Smith, J. E. - 11

Sochor, D. - 61,81,83,87

SOLANDER, D. - 16, 26, 27, 29, 33 
SPIX, J. B. Vo. $-61,65-69,99$, 111,145

Stobaeus, K. -1

Strandman, B. - 4

Strussenfelt, Major-General - 9

Sylveira - see SILVEIRA-CALDEIRA

Tapaiawar -133

Taunay - 150

Taunay, A. A. - 54, 55, 56, 124 . 126

Thouin -20

Thunberg, K. P. $-25,57,109$

Thurn und Taxis, Prince von -65

Tönder Lund, N. - 21, 29, 30

Touanne, E. de la -132

Touchard - 126

Urquijo, Marquis L. - 35

Valença, Marquis of - 145

Valenciennes - 125

Vallisnieri - 26

Vaucquelin - 144

VAUTHIER - 144, 192
Velloso, J. M. da C. $-1+5$

VIRMOND $-110,112$

Waldeck, Prince C. von -50

Waldheim, F. von -34

Waninika - 133

Weber - 27

Weddel, H. A. - 91, 150

Werner, A. G. - 34

Westermann - 112

WESTIN, 1. - 57, 109, 112

Wied-Neuwied, M., Prince zu 59, 79, 85

Wiedemann, C. R. W. - 79, 108, 111-113

Wildenow, K. L. - 33, 57

Winthem, von - 88,112, 191

Wrbna, Count von - 60,65

Yates - see YEATS

YEATS, T. P. -22

Young -26

ZANI, F. R. $-\mathrm{I}+5$ 


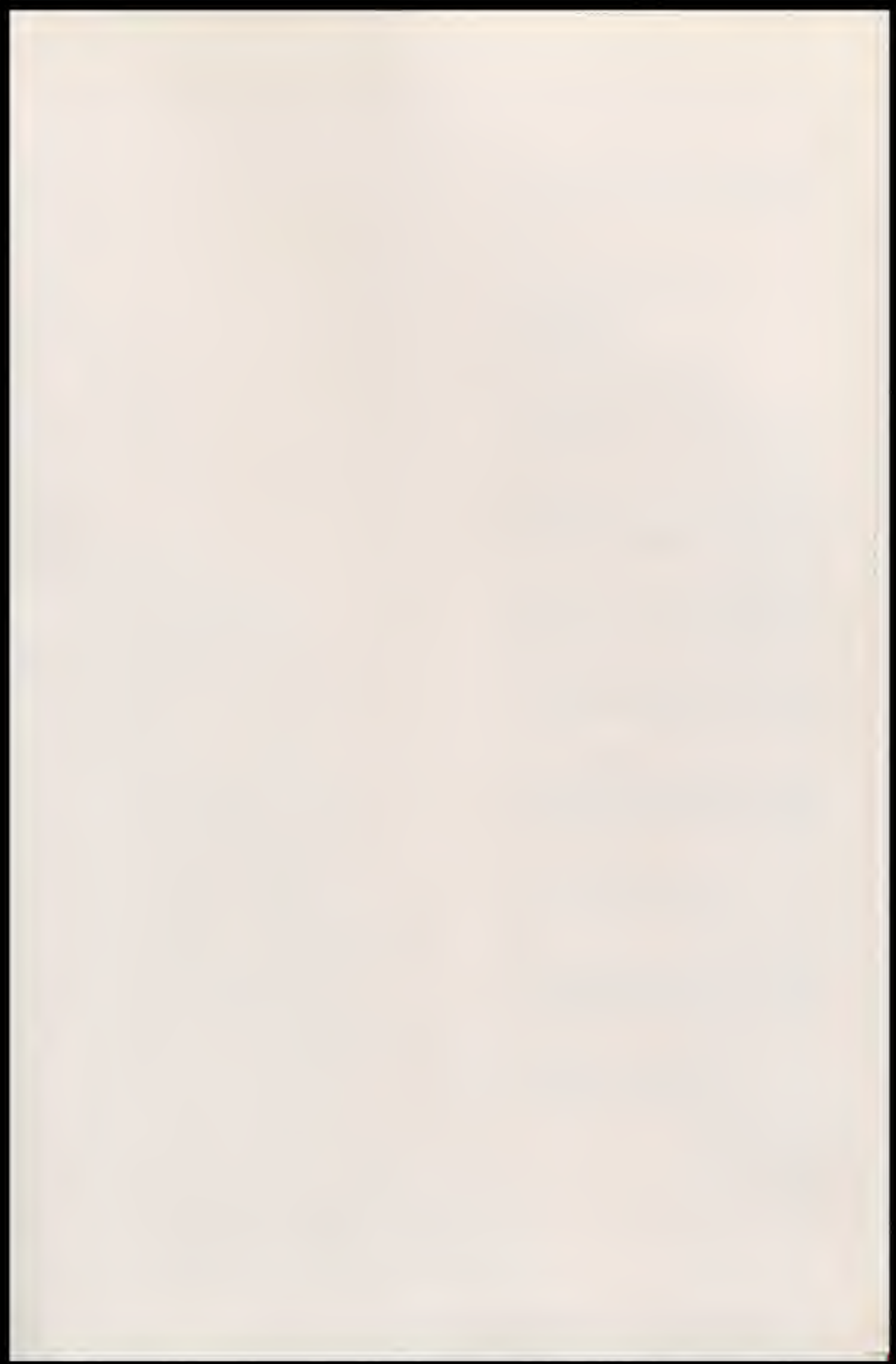

ता|

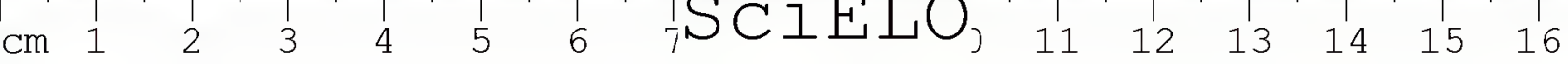


CONTENTS OF THIS VOLUME

Chapter I

The Systema Naturae

Chapter II

The Period of Fabricius

Chapter 111

THE LIFE AND WORKS OF J. C. FABRICIUS

Chapter IV

Travels of Humboldt and Bonpland

Chapter V

Collectors in Brazil (1801-1835)

Chapter VI

Collectors in Mexico and the West INDIES

Chapter VII

Thunberg, ERIChson, Perty aNd WIEDEMAN

Chapter VIII

The FreNCH COLLECTORS

Chapter $I X$

ENTOMOLOGical COLlectors in MeXICO AND CUBA

Chapter $X$

The FreNCH DIPTERISTS

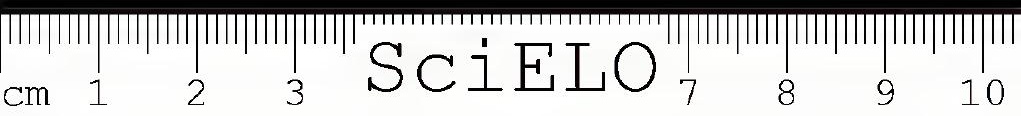




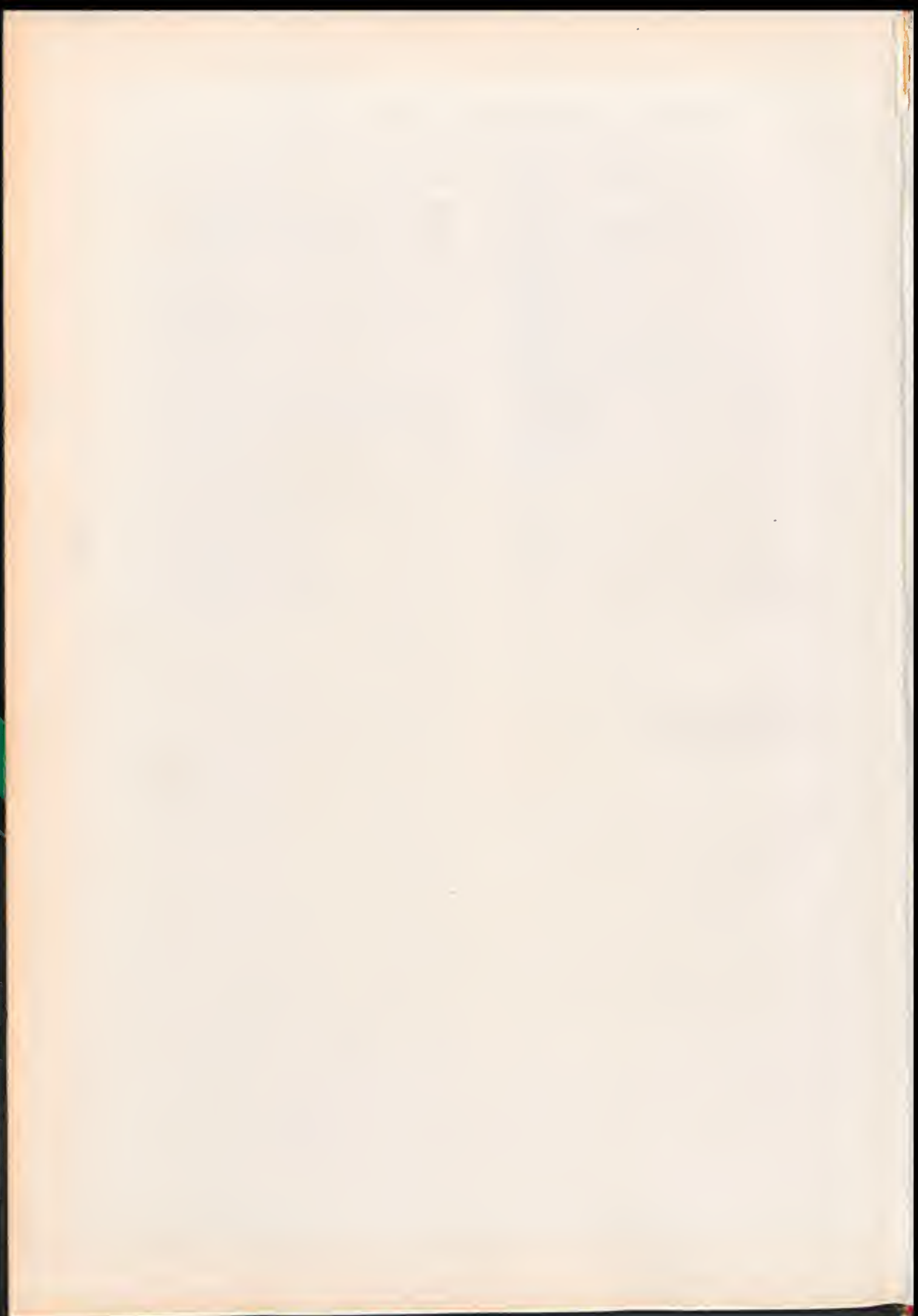

|

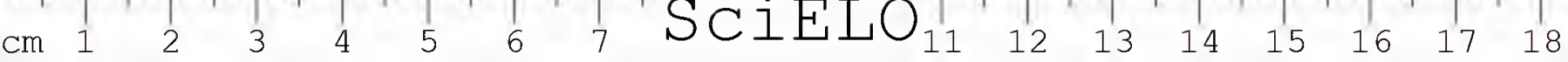


595.77 Papavoro, Nelson

P213e Essays on the History of

v.l Neotropical Dipterology...

5495

S A Í D A ENTRADA

595.73

Yir 13 e

v. I

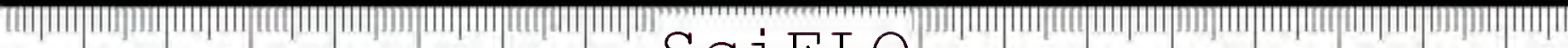

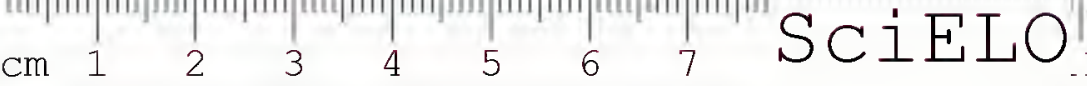




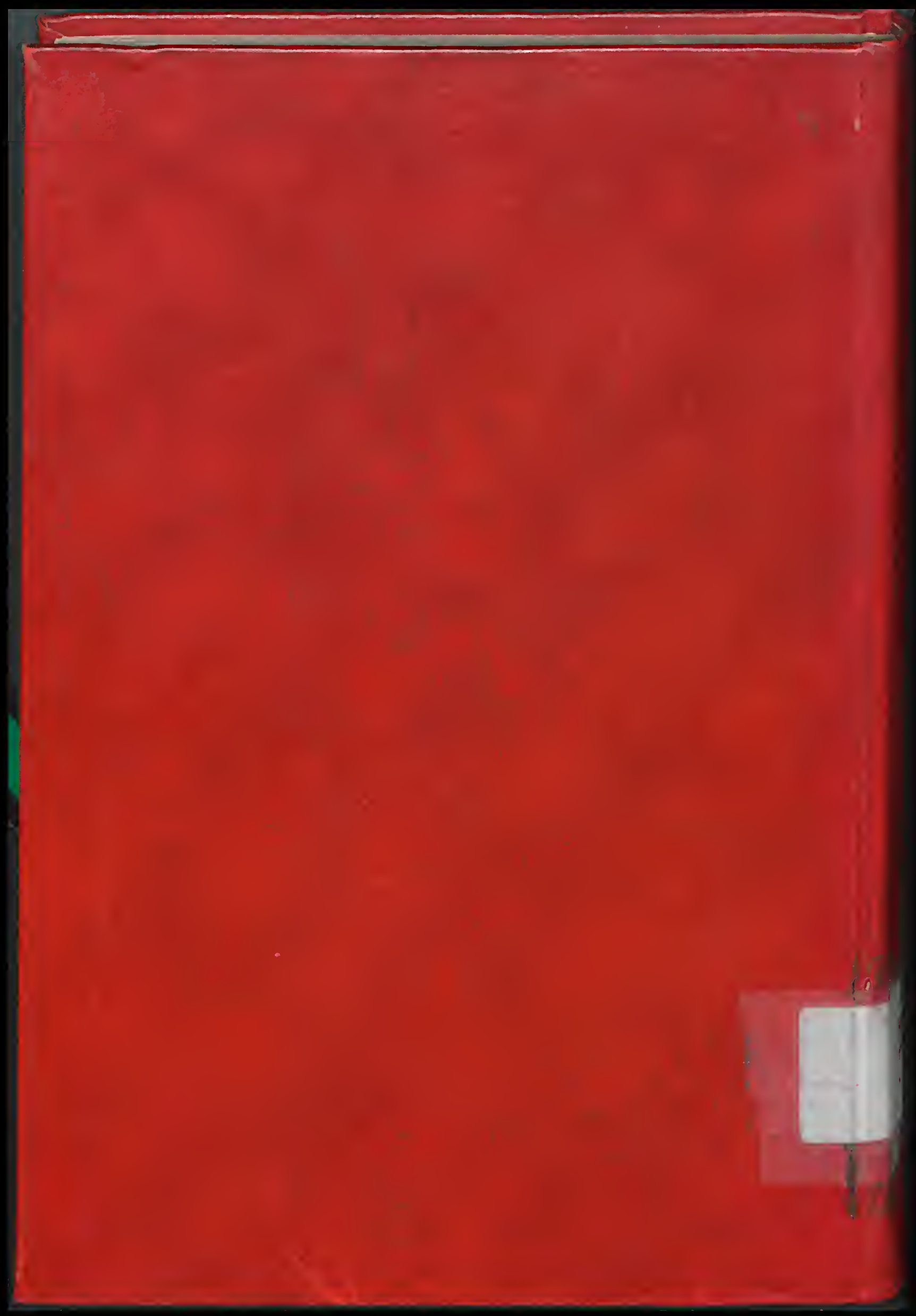

\begin{tabular}{c|ccccccc|ccccccc} 
& \\
$\mathrm{cm}$ & 1 & 2 & 3 & 4 & 5 & 6 & 7 & 8
\end{tabular} 